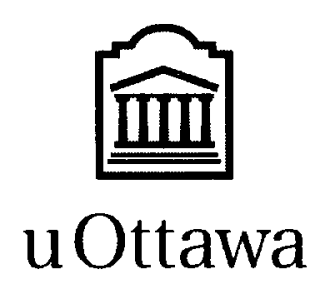

L'Université canadienne Canada's university 
FACULTÉ DES ÉTUDES SUPÉRIEURES ET POSTOCTORALES
魚

uOttawa

L'Université canadienrne

Canada's university
FACULTY OF GRADUATE AND POSDOCTORAL STUDIES

Devin Zane Shaw

AUUTEURR DE LA THESE / AUTTHOR OF THESIS

Ph.D. (Philosophy) GRADE/DEGREE

Department of Philosophy

FACULTE, ECOLE, DEPARTEMENT / FACULTYY, SCHOOL, DEPARTMENT

Freedom and Nature in Schelling's Philosophy of Art

TITRE DE LA THÉSE / TITLE OF THESIS

Jeffrey Reid

DIRECTEUR (DIRECTRICE) DE LA THESE/ THESIS SUPERVISOA

CO-DIRECTEUR (CO-DIRECTRICE) DE LA THESE T THESIS CO-SUPERVISOR

Frederick Beiser (Syracuse University)

Denis Dumas

Douglas Moggach

Sonia Sikka

Gary W. Slater 


\title{
Freedom and Nature in Schelling's Philosophy of Art
}

\author{
Devin Zane Shaw
}

Thesis Submitted to the

Faculty of Graduate and Postdoctoral Studies

In partial fulfillment of the requirements

For the $\mathrm{PhD}$ degree in Philosophy

Department of Philosophy

Faculty of the Arts

University of Ottawa

(C) Devin Zane Shaw, Ottawa, Canada, 2009 


$\begin{array}{ll}\begin{array}{l}\text { Library and Archives } \\ \text { Canada }\end{array} & \begin{array}{l}\text { Bibliothèque et } \\ \text { Archives Canada }\end{array} \\ \begin{array}{l}\text { Published Heritage } \\ \text { Branch }\end{array} & \begin{array}{l}\text { Direction du } \\ \text { Patrimoine de l'édition }\end{array} \\ \begin{array}{l}\text { 395 Wellington Street } \\ \text { Ottawa ON K1A ON4 } \\ \text { Canada }\end{array} & \begin{array}{l}395, \text { rue Wellington } \\ \text { Ottawa ON K1A ON4 } \\ \text { Canada }\end{array}\end{array}$

Your file Votre réference

ISBN: 978-0-494-61259-0

Our file Notre refférence

ISBN: $978-0-494-61259-0$

NOTICE:

AVIS:

The author has granted a nonexclusive license allowing Library and Archives Canada to reproduce, publish, archive, preserve, conserve, communicate to the public by telecommunication or on the Internet, loan, distribute and sell theses worldwide, for commercial or noncommercial purposes, in microform, paper, electronic and/or any other formats.

The author retains copyright ownership and moral rights in this thesis. Neither the thesis nor substantial extracts from it may be printed or otherwise reproduced without the author's permission.

L'auteur a accordé une licence non exclusive permettant à la Bibliothèque et Archives Canada de reproduire, publier, archiver, sauvegarder, conserver, transmettre au public par télécommunication ou par l'Internet, prêter, distribuer et vendre des thèses partout dans le monde, à des fins commerciales ou autres, sur support microforme, papier, électronique et/ou autres formats.

L'auteur conserve la propriété du droit d'auteur et des droits moraux qui protège cette thèse. $\mathrm{Ni}$ la thèse ni des extraits substantiels de celle-ci ne doivent être imprimés ou autrement reproduits sans son autorisation.
In compliance with the Canadian Privacy Act some supporting forms may have been removed from this thesis.

While these forms may be included in the document page count, their removal does not represent any loss of content from the thesis.
Conformément à la loi canadienne sur la protection de la vie privée, quelques formulaires secondaires ont été enlevés de cette thèse.

Bien que ces formulaires aient inclus dans la pagination, il n'y aura aucun contenu manquant. 


\section{Table of Contents}

Abstract $\quad$ iv

Acknowledgements vi vi

Abbreviations vii

Introduction 1

Chapter 1: Dogmatism, Criticism and Art 10

$\begin{array}{ll}\text { 1.1. The Primacy of Freedom } & 10\end{array}$

$\begin{array}{ll}\text { 1.2. The Pantheism Controversy } & 14\end{array}$

$\begin{array}{ll}\text { 1.3. Fichte's Science of Knowledge } & 21\end{array}$

1.4. The Practical Rivalry of Dogmatism and Criticism 32

1.5. The Sublime of Greek Tragedy and the Interests of Reason 48

Chapter 2: From Nature-philosophy to the "Mythology of Reason" 53

2.1. Nature-Philosophy and the Beginning of the Philosophy of Art 53

2.2. Fichte, Kant, and the Thing in Itself 58

2.3. Appropriating Spinoza and Leibniz 61

2.4. The History of Self-Consciousness 66

2.5. A Natural Doctrine of the Mind 70

$\begin{array}{ll}\text { 2.6. Toward a Philosophy of Art } & 77\end{array}$ 
Chapter 3: Artistic Activity and the Subversion of Transcendental Idealism

3.1. The System of Subversion $\quad 87$

3.2. The Limits of Theory and Practice 96

3.2.1. Theory 96

$\begin{array}{lr}\text { 3.2.2. Practice } & 99\end{array}$

3.3. Teleology and Nature-philosophy 105

3.4. From the "Phenomenology of Genius" to the New Mythology 110

Chapter 4: Substance and History: Art and the System of Identity 124

4.1. The Light of $1801 \quad 124$

4.2. The Turn to Absolute Reason 130

4.3. The Relationship between Art and the Absolute 139

4.4. The Gods of Art 146

4.5. Substance or History? 158

Chapter Five: From Art and Nature to Revelation and Freedom 160

5.1. The Moment in Munich $\quad 160$

5.2. From the "Living Center" of Nature and Art... 167

5.3. ...to Theological Anthropology 184

5.4. The Politics of Mythology and the Mythology of Politics 192

$\begin{array}{ll}\text { Conclusion } & 201\end{array}$

$\begin{array}{ll}\text { Bibliography } & 210\end{array}$ 


\section{Abstract}

The goal of this thesis is to establish the centrality of the philosophy of art in Schelling's thought from the System of Transcendental Idealism (1800), through the period known as his absolute idealism or identity-philosophy (1801-1806), to the address Über das Verhältnis der bildenden Künste zu der Natur of 1807. One of the central problems of previous interpretations of Schelling's philosophy of art is the lack of clear and comprehensive criteria for establishing the similarities and differences among his various presentations. In order to establish a measure for evaluating the continuity of Schelling's philosophy of art, I focus on demonstrating the structural features that are consistent from 1800 to 1807 :

1) What philosophy constructs in the ideal, art produces in the real. Thus artistic activity is the highest human vocation (Bestimmung) because practical philosophy can only approximate its object, which is the moral law.

2) While both the natural organism and the artwork embody the same identity of real and ideal, of necessity and freedom, the work of art overcomes these oppositions through the identity of conscious and unconscious production, whereas the organism's activity is unconscious.

3) Artistic production has a socio-political task: it aims to overcome the fragmentary condition of modernity through a new mythology and artistic renewal. 
All of these features are first outlined in the System of Transcendental Idealism and are maintained through 1807. I argue that they can be understood in relation to Schelling's ideas of freedom and nature. The philosophy of art emerges as a solution to the problem of how to show that human activity can be objectified within the real world. For the philosophy of art, the objective result is the artwork. Thus for Schelling, artistic production exhibits an ethic of free activity that was 'more free than freedom,' as freedom was conceived, in Kant and Fichte, as conformity to the moral law. Though he also thinks freedom as an infinite approximation to a regulative ideal, Schelling adds that artistic activity actually produces its own law, as beauty, in the harmony of form and content of the work, which exhibits the identity of freedom and necessity, and the self and nature. Art presents the absolute in the finite world, and makes possible a new mythology that can unify humanity.

I conclude by arguing that Schelling abandons the philosophy of art when he shifts his concern to the relationship between freedom, revelation, and theology. Schelling's orientation turns from a hopeful future of humanity, realized in a new mythology, to a focus on Christian revelation, the figure of Christ and the idea of human freedom as positive capacity for good or evil. In this account, Schelling reduces the role of art to the production of a work of nostalgia for a lost connection to nature. Art is reduced to this role because Schelling now conceives of freedom, and virtue, as the highest activity of human being; but this idea of freedom is of an ecstatic or existential nature. Schelling elevates human freedom to the pinnacle of the system when he finally surpasses its conception as an activity that approximates the moral law. In the Philosophical Investigations into the Essence of Human Freedom of 1809, and the Stuttgart Seminars given a year later, freedom is rethought as a positive, ecstatic act of inner law-giving, which is realized as virtue. 


\section{Acknowledgements}

The origins of this thesis can be traced at least as far back as my supervisor Jeffrey Reid's graduate seminar "The Self and Its World in Fichte, Schelling and Early German Romanticism," of Winter 2005, in which I first read Schelling's work. It would not have been the same project without his constant encouragement and constructive criticism. The comments and suggestions of my committee, comprised of Denis Dumas, Douglas Moggach, and Sonia Sikka, helped to push my research beyond the project phase, and Frederick C. Beiser's incisive criticism improved the final draft.

I would also like to thank my family and friends, in academia and otherwise, who listened, nodded, and gave support through the process of my writing and researching. Mark Young, Mark Raymond Brown and Dean Wm. Lauer all had to listen to endless philosophical speculations as I worked through Schelling's philosophy of art, and near the end, Mark Raymond Brown read part of the first draft. Sascha Maicher helped out when Schelling's German appeared to be opaque. My family supported my university education even when they weren't sure when it would end. Finally, my wife Caroline had patience during the time I was knee-deep in the absolute.

-D.Z.S., December 1, 2009 


\section{Abbreviations}

The following is a list of frequently used abbreviations that appear in the main text and footnotes. All references to Schelling's work cite the page of the English translation, when available, followed by the volume and pagination from K.F.A Schelling's edition of his father's work, as reproduced in Schellings Werke. Nach der Original Ausgabe in neuer Anordnung. 12 vols. Ed. Manfred Schröter (Munich: Beck, 1927-1959). Some translations have been modified for consistency. I have also tried to utilize where possible the gender neutral term 'humanity' for my own discussions of Schelling's philosophy, where he uses the German Mensch and its cognates, which while implying a neutral gender, too often meant in his time, men.

\section{Schelling:}

AA Historisch-kritische Ausgabe. Ed. H.M. Baumgartner, W.G. Jacobs, H.

Krings (Stuttgart: Frommann-Holzboog, 1976-). Cited by Division/Volume/Page.

$S W$ Schellings Werke. Nach der Original Ausgabe in neuer Anordnung. 12 vols. Ed. Manfred Schröter (Munich: Beck, 1927-1959). 
Darstellung Darstellung meines Systems der Philosophie, translated as "Presentation of My System of Philosophy" by Michael Vater, in The Philosophical Forum XXXII No.4 (Winter 2001), 339-371.

First Outline Erster Entwurf eines Systems der Naturphilosophie, translated as First Outline of a System of the Philosophy of Nature by Keith R. Peterson (Albany: SUNY Press, 2004).

$H F$

Philosophische Untersuchungen über das Wesen der menschlichen Freiheit, translated as Philosophical Investigations into the Essence of Human Freedom by Jeff Love and Johannes Schmidt (Albany: SUNY Press, 2006).

HMP Zur Geschichte der neueren Philosophie, translated as On the History of Modern Philosophy by Andrew Bowie (Cambridge: Cambridge University Press, 1994).

Ideas Ideen zu einer Philosophie der Natur, translated as Ideas for a Philosophy of Nature by Errol E. Harris and Peter Heath (Cambridge: Cambridge University Press, 1988).

Letters Philosophische Briefe über Dogmatismus und Kritizismus, translated as "Philosophical Letters on Dogmatism and Criticism," in The Unconditional in Human Knowledge, ed. Fritz Marti. (Lewisburg: Bucknell University Press, $1980), 156-218$.

MR Über das Verhältnis der bildenden Künste zu der Natur, abbreviated as Münchener Rede, translated as "Concerning the Relation of the Plastic Arts to Nature (1807)" by Michael Bullock, in Herbert Read, The True Voice of Feeling (London: Faber and Faber, 1968), 323-364. 
PA Philosophie der Kunst translated as The Philosophy of Art by Douglas W. Stott (Minneapolis: Univeristy of Minnesota Press, 1989).

Plitt Aus Schellings Leben In Briefen. Ed. G.L. Plitt. 3 Volumes (Hildesheim: Georg Olms Verlag, 2003 [Reprint of 1870 edition]).

SP Stuttgarter Privatvorlesungen, translated as Stuttgart Seminars in Idealism and the Endgame of Theory, ed. Thomas Pfau (Albany, SUNY Press, 1994), 195-243.

$S T$

System des transzendentalen Idealismus, translated as System of Transcendental Idealism by Peter Heath (Charlottesville: University Press of Virginia, 1978).

"Survey" Allgemeine Uebersicht der neuesten philosophischen Literatur, partially translated as the "Treatise Explicatory of the Idealism in the Science of Knowledge (1797)," in Idealism and the Endgame of Theory, ed. Thomas Pfau (Albany, SUNY Press, 1994), 61-138.

Würzburg Lectures: System der gesamten Philosophie und der Naturphilosophie insbesondere, partially translated in Idealism and the Endgame of Theory, ed. Thomas Pfau (Albany, SUNY Press, 1994), 139-194.

\section{Hölderlin:}

HSA Sämtliche Werke. Ed. Friedrich Beissner (Stuttgart: Verlag W. Kohlhammer, 1943-1985). Most quotations cite the English translation from Essays and Letters on Theory. Ed. Thomas Pfau (Albany: SUNY Press, 1988), when available, and then the Werke by volume then page. 


\section{Fichte:}

$S K$

The Science of Knowledge. Ed. Peter Heath and John Lachs (Cambridge: Cambridge University Press, 1982). All references to Fichte (except to his letters) cite the English translation followed by the pagination of Johann Gottlieb Fichtes sämmtliche Werke. 8 vols. Ed. I.H. Fichte (Berlin: Veit, 1845-1846.) as provided by the J.G. Fichte: Gesamtausgabe der Bayerischen Akademie der Wissenschaften. Ed. Reinhard Lauth, Hans Jacobs, and Hans Gliwitsky (Stuttgart-Bad Cannstatt: Fromann-Holzboog, 1964-).

\section{Hegel:}

Werke Werke in zwanzig Bänden. Ed. Eva Moldenhauer and Karl Markus Michel (Frankfurt am Main: Suhrkamp, 1971).

Kant: All references to Kant are cite the English translation followed by the volume and pagination of Gesammelte Werke (Preussischen Akademie der Wissenschaften (Berlin: de Gruyter, 1900-), with the exception of the Critique of Pure Reason, which follows the pagination of the 1781 (A) and 1787 (B) editions. 
...is Achilles possible with powder and lead? Or the Iliad with the printing press, not to mention the printing machine? Do not the song and the saga and the muse necessarily come to an end with the printer's bar, hence do not the necessary conditions of epic poetry vanish?

But the difficulty lies not in understanding that the Greek arts and epic are bound up with certain forms of social development. The difficulty is that they still afford us artistic pleasure and that in a certain respect they count as a norm and as an unattainable model.

-Karl Marx, Grundrisse, p. 111. 


\section{Introduction}

The first difficulty found in the work of Friedrich Schelling is the beginning, which is not surprising given that the foundation of his philosophy is an immediate, intellectual intuition. There are numerous systems and numerous beginnings to these systems, but in each, despite the changing rhetoric, preparatory remarks and vocabularies, there stands an intellectual intuition of the totality. These difficulties with Schelling's thought present several questions for the interpreter or historian who addresses his philosophy and who attempts to reconstruct its development systematically. How many beginnings? One fundamental thought or many? When does one series of developments begin, and when does one end?

It is not the purpose of this study to answer all these questions definitively. In fact, they are often questions with which one begins to think and to philosophize along with Schelling's work, and that fade into the background as one discovers the depth and detail of his texts, until the surprise that some aspect in one work anticipates another that may be from decades later, or that some subsequent self-interpretation by Schelling underlines an intention or omits one with which he was later not concerned.

The study you have before you began as research into the fate of Schelling's philosophy of art, and as it slowly progressed, I discovered that the these questions stood at the forefront of Schelling's own thought as it unfolded, changed, and re-assessed itself. 
Hence, in the Philosophy of Art, which is comprised of lectures given in Jena in 1802-1803 and a year later in Würzburg, Schelling asks his audience not to

confuse this science of art with anything previously presented under this or any other title as aesthetics or as a theory of the fine arts and sciences. There does not yet exist anywhere a scientific and philosophical doctrine of art. At most only fragments of such a doctrine exist, and even these are little understood and can be comprehended only within the context of the whole $(P A, 11 / 5: 361)$.

There have been theories of judgment and taste, technical training, art histories, and even virtual "cookbooks in which the recipe for a tragedy reads approximately as follows: a great deal of fright, but not too much, as much sympathy as possible, and tears without end" ( $P A$, 12/5: 362), though no philosophy of art that has sought to think the absolute truth of art, the idea (taken in the Platonic sense) of art. Schelling's is one of the first.

It is the goal of an academic thesis to make an original contribution to an existing body of knowledge. My thesis contributes to the research on the work of Schelling and early German idealism in at least three ways. First, it establishes the centrality of the philosophy of art in Schelling's thought, not only in the System of Transcendental Idealism (1800), but through the entire period from 1800 to the address Über das Verhältnis der bildenden Künste $z u$ der Natur of 1807. Second, after establishing the centrality of his philosophy of art, it rereads Schelling's philosophical development from 1801 to 1810 through the often overlooked or underappreciated Philosophy of Art, Über das Verhältnis der bildenden Künste zu der Natur and the Stuttgart Seminars. Third, it offers a new argument for the eclipse of the philosophy of art in Schelling's thought after 1807.

Let us begin with the first point, concerning the centrality of Schelling's philosophy of art. In order to establish a measure for evaluating the continuity of his philosophy of art, I focus on demonstrating the structural features that are consistent within the period from 1800 
to 1807 . One of the central problems of previous interpretations of Schelling's philosophy of art is the lack of clear and comprehensive criteria for establishing the similarities and differences between his various presentations. So, although the reasons vary, the standard interpretation holds that the System of Transcendental Idealism is the only text that holds art to be central to the system. ${ }^{1}$ One of the main reasons for this interpretation is that Schelling shifts from the subjective idealism of the System of Transcendental Idealism to the absolute idealism of the Darstellung meines Systems der Philosophie of 1801. While it is true that in the latter text Schelling rejects the subjective idealism of the System of Transcendental Idealism, the structural features of the philosophy of art and their relation to his metaphysics remains the same within the Philosophy of Art found in the period of absolute idealism, and in his philosophy through 1807. I identify Three Conditions, drawn from the System of Transcendental Idealism, to which I will return in later chapters:

C1. What philosophy constructs in the ideal, art produces in the real. Thus artistic activity is the highest human vocation (Bestimmung) because practical philosophy can only approximate its object, which is the moral law.

C2. While both the natural organism and the artwork embody the same identity of real and ideal, of necessity and freedom, the work of art overcomes these oppositions through the identity of conscious and unconscious production, whereas the organism's activity is unconscious.

\footnotetext{
${ }^{1}$ Although their reasoning varies, this includes, amongst others, Antoon Braeckman, "From the Work of Art to Absolute Reason: Schelling's Journey Toward Absolute Idealism," in The Review of Metaphysics 57 (March 2004), 551-569; Joseph P. Lawrence, "Art and Philosophy in Schelling," in The Owl of Minerva 20 (1988), 519; Andrew Bowie, Aesthetics and Subjectivity: From Kant to Nietzsche (Manchester: Manchester University Press, 1990), 84-88; and Frederick C. Beiser, German Idealism: The Struggle Against Subjectivism 1781-1801 (Cambridge, Mass., Harvard: 2002), 584-585.
} 
C3. Artistic production has a socio-political task: it aims to overcome the fragmentary condition of modernity through a new mythology and artistic renewal.

All of these features are first outlined in the System of Transcendental Idealism and maintained through 1807. As I argue, these three conditions can be understood in relation to Schelling's ideas of freedom and nature. The philosophy of art emerges as a solution to the problem of how to show that human activity- and this includes philosophy- can be objectified within the real world. For the philosophy of art, the objective result is the artwork. Thus during this time, for Schelling, artistic production exhibited a power or ethic of free activity that was 'more free than freedom' as freedom was conceived, in Kant and Fichte, as conformity to the moral law. Though he thinks freedom- like Kant and Fichte- as an infinite approximation to a regulative ideal, Schelling adds that artistic activity actually produces its own law, as beauty, in the harmony of form and content of the work, and in doing so, it exhibits the identity of freedom and necessity, the self and nature, and the ideal and the real. Art presents the absolute in the finite world.

I begin, then, with the 'pre-history' of Schelling's philosophy of art, by tracing the development of the philosophical problems in which artistic activity is his solution. In the first chapter, I show how Schelling begins to outline the relationship between freedom, nature and art in his Philosophical Letters on Dogmatism and Criticism of 1795-1796. He manages to mediate between several of the most important intellectual debates of his time, in ten short letters, written to a fictional Spinozist, who may have been based on his friend Friedrich Hölderlin. There, Schelling defends critical philosophy as a superior system of philosophy over Spinozist dogmatism, a judgment that is determined through the way in which each system interprets the relationship between the self and the world. The dogmatist 
relinquishes his or her autonomy to the idea of an ultimate power outside of the self (to necessity), while the critical philosopher asserts, through theory and practice, the primacy of the self's freedom. I begin with the Letters because it contains an analysis of Greek tragedy in comparison to criticism and dogmatism. Schelling argues that tragedy exhibits the identity of freedom and necessity through the interplay of the protagonist acting freely and yet ultimately succumbing to the power of fate. Despite his praise for Greek tragedy, which Schelling calls the highest of sublime representations of the human condition, he argues that it cannot not provide a model for a system of freedom. Instead, any attempt to forfeit the power of human freedom to the external world acts against the truth of practical philosophy. While not yet presenting a philosophy of art, the Letters anticipate some of Schelling's later philosophical concerns, to which the philosophy of art comprises the answer.

In Chapter Two, I reconstruct Schelling's sketch of what he calls the "history of selfconsciousness" from the Ideas for a Philosophy of Nature of 1797 and the Allgemeine Uebersicht der neuesten philosophischen Literatur (or "Survey"), which was published in installments from 1797-1798 in Immanuel Niethammer's and Fichte's, Philosophisches Journal. The 'history of consciousness' is Schelling's attempt to develop a critical idealism that could demonstrate how self-consciousness arises within nature and within human history, that is, how self-consciousness progressively overcomes its previous limitations through its interaction with nature and history. Thus, on the one hand, Schelling develops this system ideally in the "Survey," and on the other, he proposes a nature-philosophy in the Ideas that outlines a real natural doctrine of the mind. The purpose of both is to show how a completed system of critical idealism could reconcile the differences that marked humanity's 'modern condition,' and the philosophical assumptions that separated humans from nature, 
and freedom from necessity. As this history of consciousness develops, I argue, it appears, in vague outline, that both systems, of idealism and nature-philosophy, require a third to resolve their contradictions. This third part of philosophy is a philosophy of art. The chapter closes with a reading of the "Älteste Systemprogramm des deutschen Idealismus," a dense fragment that argues that beauty, poesy and a mythology of reason are the highest realizations of philosophy. These are all features that, whether Schelling was the author or not, will reappear in his philosophy of art.

In Chapter Three, I outline Schelling's philosophy of art found in the System of Transcendental Idealism. I argue that the introduction of the philosophy of art should be read as a subversion of Fichte's emphasis on practical reason. So, where Fichte grounds his system in the self's free activity, Schelling now argues that the true realization of human activity is in the work of art, which is objectively produced. Where freedom- as conceived as an infinite approximation of the moral law- can only strive toward its object, artistic activity is grounded in the identity of freedom and necessity, when it produces the inner harmony and beauty of a work of art. Thus artistic production, through genius, is an activity that is 'more free than freedom itself,' a kind of ethos that produces according to its own laws. In addition, I also show that all three conditions, listed above, are established in the System of Transcendental Idealism. While it is the first systematic presentation of Schelling's philosophy of art, it is not his last.

Therefore, in the first half of Chapter Four, I demonstrate that all of these conditions obtain in Schelling's Philosophy of Art, which was written and delivered as lectures during the period of his system of absolute idealism or 'system of identity.' Even if the first principle of the system shifts from the self's activity to, according to Schelling, the 
standpoint of reason itself, the Philosophy of Art still maintains all three conditions. Furthermore, it is in detailing the task of a new mythology that we discover that Schelling's absolute idealism encounters a contradiction that it cannot resolve, a contradiction between substance (the first principle of the system) and history (the mythological revelation of its content). This occurs because Schelling holds that the first principle of the system of identity is an eternal and infinite substance, an identity of form and content, while at the same time presenting a historical construction of art that presents a series of divine revelations within history. This series begins with Greek mythology and leads to Christian revelation, in which Christ is revealed as the closure of antiquity and the origin of the modern era. The Philosophy of Art results in the following dilemma: either retain the first principle, and reduce the historical revelation to mere appearances (contradicting the infinite quality of the gods, and the Christian God), or maintain the historical revelation of Greek and Christian mythology, and abandon the immutable and eternal Spinozist substance.

Schelling will attempt to grapple with the problem of history within the system of identity until 1807, in his address to the Akademie der Wissenschaft in Munich. In the Über das Verhältnis der bildenden Künste zu der Natur, Schelling departs from the system of absolute idealism and turns to a system of historical revelation that anticipates his later philosophy of freedom that begins in 1809. In Chapter Five I argue that this often neglected text deserves a more attention because, at the turning point between the philosophy of art and the philosophy of freedom, Schelling proposes a singular account of an ethos that unifies the true, the good and the beautiful through artistic production. Artistic activity reveals the true, because art reproduces the history of natural production itself, as it reveals the divine in humanity; it reveals the good, because artistic production presents an ethic of moderating the 
passions through the creation of beauty. Schelling invokes this ethos to call for a renewal of art within the public sphere, which would express the essence of the German people on the stage of history.

Yet if Über das Verhältnis der bildenden Künste zu der Natur presents such a singular ethos, it is important to search for the reasons why Schelling abandons his philosophy of art. Therefore the last chapter also traces the end of the philosophy of art to Schelling's shift toward a philosophy of freedom and his interest in the relationship between freedom, revelation, and theology. This shift leads to the Stuttgart Seminars, where I argue that Schelling's orientation turns from a hopeful future of humanity, to an account of the distant past of humanity's Fall. While Schelling develops the Fall and its consequences as a historical narrative, his focus turns to Christian revelation, the figure of Christ and the idea of human freedom as positive capacity for good or evil. In this account, Schelling diminishes the role of art to the production of a work based either in the artist's individuality, or as a work of nostalgia for a lost connection to nature. Art is reduced to this role because Schelling now conceives of freedom, and virtue, as the highest activity of human being; but this idea of freedom is of an ecstatic or existential nature. Schelling elevates human freedom to the pinnacle of the system when he finally surpasses its conception as an activity that approximates the moral law; in the Philosophical Investigations into the Essence of Human Freedom of 1809, and the Stuttgart Seminars a year later, freedom is rethought as a positive, ecstatic act of inner law-giving, which is realized as virtue.

After showing how Schelling returns to the primacy of freedom, albeit through both the criticism of Kant, Fichte, and his own previous work, I close this study by evaluating the political implications of Schelling's call for a new mythology and renewal of art. I argue that 
while his earlier texts display a revolutionary and utopian vision of the new mythology, the later texts justify the call for a new mythology and its concept of an organic society through the state, and vice versa. It is remarkable that, long after Schelling had given up on the political and social effects of art, both visions, one revolutionary and the other conservative, have resonated through the $19^{\text {th }}$ and $20^{\text {th }}$ centuries: the idea that a new mythology can, and should, express the essence of a people, nation or community, had a long history, while the revolutionary and utopian conception of artistic production re-emerges in the avant-gardes of the $20^{\text {th }}$ century, and still inspires philosophical debate in the $21^{\text {st }}$. 


\section{Chapter 1}

\section{Dogmatism, Criticism and Art}

\subsection{The Primacy of Freedom}

Although Schelling's System of Transcendental Idealism (1800) is the first systematic account of his art-philosophy, he first proposes art- namely the content of Greek tragedy-as a solution to the philosophical problem of freedom in the Philosophical Letters on Dogmatism and Criticism (1795-1796). ${ }^{1}$ In ten densely written epistles, Schelling begins to develop both his own system of philosophy and the relationship between art and philosophy through a discussion guided by the prominent philosophical debates at the end of the $18^{\text {th }}$ century, driven by the Pantheism Controversy and the ascendancy of the critical philosophy of Kant, Reinhold, and Fichte. With the inclusion of a discussion of art, Schelling also considers the relationship between philosophy and the concerns of authors associated with the Sturm und Drang, and his friend Friedrich Hölderlin.

In this chapter I focus on the relationship between philosophy and art in the Letters, and more precisely on the relation between the practical subject, the world and art. I will argue that Schelling's emphasis on practical reason prevents him from proposing Greek tragedy as a model of action. According to Schelling, post-Kantian philosophy demands that

\footnotetext{
${ }^{1}$ All references to Schelling's work in the text of this chapter provide the page number found in Fritz Marti's translations found in The Unconditional in Human Knowledge. (Lewisburg: Bucknell University Press, 1980), followed by the volume and pagination from the $S W$.
} 
each philosopher choose practically between two mutually opposed systems, each grounded on an exclusive first principle: either critical idealism, grounded on the self, or dogmatism, grounded on the object. If we attach a philosopher's name to each position, we can say, Fichte or Spinoza. Yet, as I will show, Schelling proposes this opposition in order to defend what he saw as the spirit of Fichte's critical idealism, even as he departs from the letter. It is Schelling's defense of the practical aspects of Fichte's philosophy that prevents him from proposing tragedy as a system of action.

Before showing how this conflict between criticism and dogmatism unfolds in the Letters, we will address how Schelling came to oppose Fichte to Spinoza. Although he had already written a dissertation and published ${ }^{2}$ by the time he encountered Fichte (if not personally during the latter's visits to Tübingen in June 1793 and May $1794,{ }^{3}$ then at least in writing), Fichte's work proved to be a decisive influence on the young Schelling's thought. By his second visit, Fichte had produced an outline of a systematic unification of theoretical and practical philosophy in his Concerning the Concept of the Wissenschaftslehre. ${ }^{4}$ The system that Fichte calls the Wissenschaftslehre (doctrine of science), aims to unify theory and practice in the self-positing subject, the absolute I. This self-positing is the act whereby the subject recognizes the unity of consciousness and him or herself as freely acting. The act need not be the first temporal act of a subject, but, as we will see below, the recognition of the practical demand to act as if one's freedom were unconditional. The excitement around

\footnotetext{
${ }^{2}$ These texts are on the origin of evil, and mythology, respectively: De prima malorum humanorum origine philosophematis Gen. III explicandi tentamen criticum et philosophicum, and Uber Mythen, historische Sagen und Philosopheme der ältesten Welt.

${ }^{3}$ See Xavier Tilliette, Schelling: Biographie (Paris: Calmann-Lévy, 1999), 28-29.

${ }^{4}$ Fichte, Concerning the Concept of the Wissenschaftslehre, in Early Philosophical Writings. Ed. Daniel Breazeale (Ithaca: Cornell University Press, 1988), 94-135/1: 29-81. I will use the term Wissenschaftslehre to refer to Fichte's system, apart from any particular attempt at articulating this system. For convenience, I will refer to the Grundlage der gesamten Wissenschaftslehre by the title provided by the translators of the English edition, Science of Knowledge. Ed. Peter Heath and John Lachs (Cambridge: Cambridge University Press, 1982).
} 
the work of this incoming professor at the University of Jena was generated by his insistence on the practical primacy of a freely acting subject. Such excitement is discernable in Schelling's early Fichtean texts, On the Possibility of a Form of All Philosophy and Of the I as Principle of Philosophy.

While the Letters are a defense of criticism's emphasis on freedom and practical action, Schelling recasts dogmatism as a practical system of philosophy, noting, for instance, that Spinoza had entitled his magnum opus the Ethics. Like many of his contemporaries, such as his former classmates Hegel and Hölderlin, and others such as Friedrich Schlegel and- above all- Goethe, Schelling was a serious reader of Spinoza. The resurgence of interest in Spinoza was the result of the Pantheism Controversy, which was ignited by the publication of Jacobi's Concerning the Doctrine of Spinoza in Letters to Herr Moses Mendelssohn in 1785 . The book opens in a dramatic fashion by disclosing an avowal by G.E. Lessing-a prominent figure of the German Enlightenment- of Spinozism, which at the time referred to some combination of fatalism, atheism and materialism. Yet the stakes of Jacobi's book are philosophical: the conversations develop Jacobi's charge that all philosophical demonstration, if consistent, leads to Spinozism. Any consistent philosophy, according to Jacobi, is atheist because it can only provide proofs of a God immanent to the world, which is a disguised materialism, and fatalist because a complete system precludes the possibility of freedom and morality. By contrast, Jacobi offers a theory of knowledge and practice grounded in revelation and faith in a personal God.

While once Spinoza had been considered a "dead dog" (Lessing's words), Jacobi's polemic backfired, inspiring an entire generation of German philosophers to read the former heretic. Though Kant claimed not to understand Spinoza, and Fichte subordinated Spinozist 
dogmatism to a necessary step towards critical idealism, Schelling argued that consummate dogmatism (Spinoza) was a coordinate practical rival to criticism (thus also displacing Jacobi's division between faith and Spinozism). Yet, after establishing this rivalry, and after arguing that dogmatism could be refuted neither theoretically nor practically, Schelling sets out to refute it in both domains. Criticism ultimately demonstrates its practical superiority in its use of the principle of intellectual intuition. Intellectual intuition is introduced by Schelling to answer Jacobi's demand for an immediate intuition into the supersensuous world and as a name for Fichte's absolute I. Criticism proves itself superior to its rival by both preventing this intuition from being hypostatized as a thing-in-itself, as it is by dogmatism, and by interpreting this intuition as a regulative ideal for practical action. This opposition between criticism and dogmatism ultimately allows for the confirmation of freedom through the choice of two systems. As we will see, when Schelling claims that these two systems are coordinate rivals, he departs from the letter of Fichte's and (despite his own claims to the contrary) Kant's works. The Letters make a significant departure from Fichte by arguing for an absolute that is beyond either the subject or object, implying a higher standpoint than Fichte's absolute subject. However, at this point Schelling still argues for the primacy of criticism because it recognizes the regulative status of the absolute for the practical subject. The ambiguity over the absolute in the Letters allowed for different readings of the text: Hölderlin found an important departure from Schelling's previous convictions, while Fichte saw no reason to publicly break with his younger ally (this ambiguity underlies both Schelling's claim that the Letters were the first presentation of absolute idealism (see Chapter 4), and then, decades later, his claim that the Letters were the 
first statement regarding the necessity of a system to complement criticism, much as positive philosophy was the complement of negative philosophy). ${ }^{5}$

It is from this perspective that we can understand Schelling's reference to Greek Tragedy in the tenth epistle of the Letters. There has been a recent trend in the secondary literature to find in the Letters a philosophy of tragedy that overcomes the limitations of both criticism and dogmatism. ${ }^{6}$ By contrast, I argue that Schelling recognizes the power of tragedy for thought while tempering this power by demonstrating that a true practical philosophy must always promote and defend the idea of freedom. Hence while he recognizes that the drama of Greek tragedy presents the absolute identity of freedom and necessity in the free struggle of the mortal hero against fate, Schelling prohibits its use as a model for a system of action, because the struggle presented in tragedy always results in the hero's defeat through fate. It is, he says, in the interest of practical reason to expose any attempt to place the creative powers of the self, which should be realized in freedom, in the objective world. Although Greek tragedy presents the highest standard of art, Schelling argues that critical philosophy demonstrates the standard for practical action through freedom.

\subsection{The Pantheism Controversy}

Before turning to Fichte's Wissenschaftslehre, we will begin with a discussion of Jacobi's role in the Pantheism Controversy. The controversy, which went public after the publication of Jacobi's Concerning the Doctrine of Spinoza in Letters to Herr Moses Mendelssohn in

\footnotetext{
${ }^{5}$ See The Grounding of Positive Philosophy: The Berlin Lectures. Trans. Bruce Matthews (Albany: SUNY Press, 2007), 146/13: 82.

${ }^{6}$ Two recent works on Schelling's Letters suggest that Schelling radically breaks with Fichte in this text, and their arguments revolve around the status of tragedy and practical reason in the Letters. We will return to these recent commentaries below. See especially Theodore D. George, "A Monstrous Absolute: Schelling, Kant, and the Poetic Turn in Philosophy," in Schelling Now: Contemporary Readings. Ed. Jason M. Wirth. (Bloomington: Indiana University Press, 2005), 135-146; and Leonardo V. Distaso, The Paradox of Existence: Philosophy and Aesthetics in the Young Schelling (Dordrecht: Kluwer, 2004), pp. 105-110.
} 
1785 , rapidly transformed the philosophical landscape of Enlightenment Germany. ${ }^{7}$ Of course, the first edition of Kant's Critique of Pure Reason preceded the Doctrine of Spinoza by four years and had a longer lasting impact on philosophy, but at the time critical appraisal of Kant's critical philosophy would primarily take place in the rhetorical framework of the Pantheism Controversy. Although proceeding by different paths, both Kant and Jacobi attacked the dogmatism of Leibnizian-Wolffian philosophy. While Kant utilized refined philosophical criticism to question the domain and application of synthetic a priori judgments, Jacobi very bluntly accused all theoretical philosophy of both atheism and being inimical to practical action. While Kant separated the noumenal and phenomenal worlds, demolishing the speculative proofs for the soul, freedom and God in order to open the possibility of their application for practical action, Jacobi opposed faith and revelation to all theoretical demonstration.

By identifying the common target of Kant and Jacobi and the emphasis on the practical found in both (in Jacobi's case, blatantly, and with Kant, hinted at in the first Critique and made more explicit in the Critique of Practical Reason), it becomes possible to find the guiding thread between Jacobi, Fichte and Schelling, in their emphasis on practical action over theoretical reason. In retrospect, the crucial differences concerning the role of theoretical reason between Jacobi and these critical philosophers are more than obvious, especially in light of Jacobi's intervention in the Atheism Controversy of 1799, which cost Fichte his professorship at Jena, and the later polemic against Schelling, Von den Göttlichen

\footnotetext{
${ }^{7}$ For the historical details see Frederick C. Beiser, The Fate of Reason: German Philosophy from Kant to Fichte (Cambridge, Mass., Harvard: 1987), 44-126; George di Giovanni, "The Unfinished Philosophy of Friedrich Heinrich Jacobi," in The Main Philosophical Writings and the Novel Allwill. Ed. George di Giovanni (Montreal: McGill-Queen's University Press, 1994), 3-116; Alexander Altmann, Moses Mendelssohn: A Biographical Study (Alabama: The University of Alabama Press, 1973), 553-744; and Gerrard Vallee, ed., The Spinoza Conversations Between Lessing and Jacobi (New York: University Press of America, 1988). Dale E. Snow, Schelling and the End of Idealism (Albany: SUNY Press, 1996), directly relates the work of Jacobi to Schelling.
} 
Dingen und ihrer Offenbarung (1811), spurred in part by Schelling's address Über das Verhältnis der bildenden Künste zu der Natur (See Chapter 5). ${ }^{8}$ Yet before the later animosity, in the early 1790s, both Fichte and Schelling expressed admiration for Jacobi's work. Fichte, while acknowledging the difference between his transcendental idealism and Jacobi's realism, sought the latter's approval by attributing a common commitment- to emphasizing the practical and moral character of human being- to both sides. ${ }^{9}$ In the same spirit Schelling states in the $O f$ the $I$ that he desired "Plato's gift of language or that of his kindred spirit, Jacobi, in order to be able to differentiate between the absolute, immutable being and every kind of conditional, changeable existence" (109/1: 216). And it seems that for a time Jacobi also appreciated their work. In a letter to Jens Baggesen from 1797, Jacobi writes:

Fichte and Schelling are now referring ever more frequently, extensively and emphatically to my writings, and in all the works of the latter one can see how he has given them [e.g. Jacobi's writings] flesh and blood....For my part I must try and see if perhaps these men have succeeded in understanding me better than I do myself, and if I might not-through them-learn something better from myself than I knew I was teaching, which would in no way be impossible. $^{10}$

So it seems that all three saw important similarities in their work emphasizing the primacy of freedom. And as I will argue, they are attacking a common enemy: the dogmatism of Leibniz, Wolff, and Spinoza, until Schelling attempts to positively incorporate Spinozism into his system of philosophy. However, unlike Jacobi, Fichte and Schelling go to great lengths to defend the importance of theoretical reason. Schelling's own project will attempt

\footnotetext{
${ }^{8}$ See also Snow, Schelling and the End of Idealism, 205-215, and Lewis S. Ford, "The Controversy Between Schelling and Jacobi," in The Journal of the History of Philosophy, Vol. 3 (1965), 75-89.

${ }^{9}$ See the letters to Jacobi dated August 30, 1795 and April 26, 1796 in Early Philosophical Writings. Ed. Daniel Breazeale (Ithaca: Cornell University Press, 1988), 411-414.

${ }^{10}$ Quoted in Dale E. Snow, Schelling and the End of Idealism (Albany: SUNY Press, 1996), 207-208.
} 
to incorporate Jacobi's emphasis on an immediate insight into systematic philosophy through the principle of intellectual intuition.

Though the Doctrine of Spinoza begins with a biographical account of Lessing's discussions with Jacobi, the stakes of the book are philosophical. Jacobi makes it clear that the "principle issue" is the doctrine of Spinoza, which, as his dialogue with Lessing reveals very early on, is the highest (Lessing), or at least the most consistent (Jacobi) expression of philosophy. ${ }^{11}$ Thus, to confront Spinoza is to contest the strongest account of philosophy and the power of reason. Jacobi summarizes his argument against philosophy as such:

1. Spinoza is atheism.

2. The philosophy of the cabbala [...]is, as philosophy, nothing but undeveloped or newly confused Spinozism.

3. The Leibnizian-Wolffian philosophy is no less fatalistic than the Spinozist philosophy and leads the persistent researcher back to the principles of the latter.

4. Every avenue of [philosophical] demonstration ends up in fatalism.

5. We can only demonstrate similarities. Every proof presupposes something already proven, the principle of which is Revelation.

6. Faith is the element of all human cognition and activity. ${ }^{12}$

As this summary shows, Jacobi takes philosophical demonstration and moral action as mutually exclusive concerns: philosophical demonstration necessarily results in atheism and materialism, of which Spinoza is the most consistent expression of such demonstration, and therefore moral action requires a foundation in faith. At issue is Jacobi's understanding of the principle of sufficient reason: that each condition comes about through a necessary set of previous conditions. For Jacobi this is expressed in Spinoza's principle that 'nothing comes from nothing' (ex nihilo nihil fit), and, conversely, that 'something must necessarily come from something else.' The principle of sufficient reason, Jacobi then claims, requires an

\footnotetext{
${ }^{11}$ In the following, we will only be interested in Jacobi's reading of Spinoza and other modern philosophers, and not with whether he is accurate in his readings.

${ }_{12}$ Jacobi, Concerning the Doctrine of Spinoza in Letters to Herr Moses Mendelssohn, in The Main

Philosophical Writings and the Novel Allwill. Ed. George di Giovanni (Montreal: McGill-Queen's University Press, 1994), 233-234. Hereafter Doctrine of Spinoza.
} 
immanent, infinite cause to the world that must be mechanistic: "If there are only efficient, but no final causes, then the only function that the faculty of thought has in the whole of nature is that of observer; its proper business is to accompany the mechanism of the efficient causes." ${ }^{13}$ The mechanistic and determined chain of efficient causes, if followed consistently, does not permit for morality and freedom, because all human action is determined from without, by the infinite chain of causes. Therefore, an argument for a God immanent to the world (the Spinozist 'Hen kai pan'), according to Jacobi, cannot be for a personal God; instead, it must be, if consistent, an argument for 'pantheist' naturalism (i.e. atheism) and a materialism that dismisses human freedom as an illusion. Lessing, according to Jacobi, espouses this naturalism when he "insisted on having everything addressed to him in natural terms," while Jacobi stressed "that there cannot be any natural philosophy of the supernatural. ${ }^{14}$ A personal God, for Jacobi, must be extra-mundane and possess will.

After arguing that Spinozism and faith and revelation are incompatible, Jacobi accuses all modern philosophy (including Leibniz and Wolff) of fatalism and atheism, due to its reliance on the principle of sufficient reason. ${ }^{15}$ According to Jacobi, there is a fundamental choice between two exclusive positions: either a personal God of faith or a philosophical system. This was a damning criticism in $18^{\text {th }}$ century Germany. By connecting Leibniz to Spinoza, Jacobi implies that, at the heart of the German Enlightenment, there is a fundamental misrecognition: it is one thing to claim that the ever-difficult and -heretical work of Spinoza is fatalistic, and it is another thing to claim that Lessing casually acknowledged that the metaphysical foundations of Enlightenment philosophy were, all

\footnotetext{
${ }^{13}$ Jacobi, Doctrine of Spinoza, 189.

${ }_{14}^{14} \mathrm{Jacobi}$, Doctrine of Spinoza, 196.

${ }^{15}$ Although, as Manfred Frank argues, Jacobi's concept of a 'feeling' of faith has some foundation in the work of Kant. See The Philosophical Foundations of Early German Romanticism. Trans. Elizabeth Millán-Zaibert (Albany: SUNY Press, 2004), 56-75 and 83-84.
} 
claims to the contrary, also fatalistic. ${ }^{16}$ The challenge for critical philosophy after the Pantheism Controversy was to develop a theoretical philosophy compatible with freedom. Fichte and the young Schelling attempted to show that practical reason and theoretical reason were compatible by grounding both in the action of the self-positing subject.

In contrast to Spinoza (and, as he will claim, all theoretical reason) Jacobi offers an account of moral action grounded on faith and revelation. For Jacobi, human cognition is grounded through an immediate experience of certainty, "which not only needs no proof, but excludes all proofs absolutely"17 (it is this demand for an immediate ground that Schelling attempts to incorporate into critical philosophy). As Jacobi states, the original, immediate certainty reveals an I and a Thou (that is God), a revelation that grounds all other experiences. ${ }^{18}$ All subsequent demonstrations can only show the similarity of a new thing or proof to this original certainty. Through faith, one comes to know that first, one has a body which can be experienced, and second, there are other actual beings. His position, then, conflates the experience of things (the sensible) with divine revelation (the supersensible) through a loose use of the term faith: both the experience of things and of revelation rely on the original experience of immediate certainty.

Finally, later in the text, Jacobi adds a historicist or relativistic dimension to his argument. ${ }^{19}$ Not only does all demonstration rest on faith, but people's beliefs and actions

\footnotetext{
${ }^{16}$ It should be noted that Jacobi rehabilitates Leibniz when he finds it necessary to confront the emerging Kantian philosophy in David Hume on Faith, or Idealism and Realism in The Main Philosophical Writings and the Novel Allwill. Ed. George di Giovanni (Montreal: McGill-Queen's University Press, 1994), 253-338.

${ }^{17}$ Jacobi, Doctrine of Spinoza, 230.

${ }^{18} \mathrm{Jacobi}$, Doctrine of Spinoza, 231.

${ }^{19} \mathrm{Jacobi}$, Doctrine of Spinoza, 238-251. George di Giovanni goes to great lengths to both deny charges of irrationalism against Jacobi, and to show how Jacobi made great strides towards an "unfinished philosophy" of "historical reason." However, I see no reason to grant such a generous reading. See di Giovanni, "The Unfinished Philosophy of Friedrich Heinrich Jacobi," 82-86. Frederick C. Beiser argues that Jacobi endorses relativism by rejecting the Enlightenment belief in objective inquiry. Though others, such as Hume and Helvetius, held that interests and desires governed practical action, Jacobi extends the priority of the will over
} 
are determined by their historical situation: "one ought not to derive the actions of men from their philosophy, but rather their philosophy from their actions; that their history does not originate from their way of thinking, but rather, their way of thinking from their history."20 Yet the polemical effect of Jacobi's claim is effective only insofar as it does not apply to faith and revelation. As it turns out, history cannot be a medium for reform, only faith and religion can. A truly relativistic position would require that the concepts or experiences of faith and revelation would also be subject to the contingencies of history, that Jacobi's own position is also a product of his time. However, Jacobi does not allow this possibility: instead, his digression on historical circumstances ends in an overwrought defense of "rectitude, patriotism, love of mankind [and] fear of the Lord" ${ }^{21}$ against the moral lassitude of his age. Jacobi's apparent relativism is limited by religion: "from time immemorial all the nations" have held the conviction that religion is the only means for moral education and reform. $^{22}$

Regardless of his conclusions, Jacobi's polemic had a profound and lasting effect on the development of early German idealism. In the wake of the Doctrine of Spinoza, Schelling struggled to demonstrate the compatibility and ultimate unity of philosophy as a practice and freedom. Hence while Jacobi strictly rejects theoretical reason as the ground of practice in favor of faith, Schelling-initially following Fichte- argues that practical reason

reason "in a new and dangerous direction": to the domain of theory. As Beiser writes, "Jacobi's chief contention [is] that we cannot separate the realms of theory and practice, because knowledge is the consequence of right action, truth the result of the proper interests." Although Beiser shows that Jacobi later develops his relativistic position, I argue that in the 1785 edition of the Doctrine of Spinoza holds both that human action is relative to its historical situations and that Christianity is a universal standard of practical instruction. See Beiser, The Fate of Reason, 85-89.

${ }^{20}$ Jacobi, Doctrine of Spinoza, 239.

${ }^{21}$ Jacobi, Doctrine of Spinoza, 241.

22 Jacobi, Doctrine of Spinoza, 242-243. Beiser argues, that despite appearances, Jacobi was at the same time an "advocate of the fundamental ideals of the Aufklärung- liberty of conscience, religious toleration [and] equality before the law." See Enlightenment, Revolution, and Romanticism (Cambridge, Mass., Harvard: 1992), 138153. 
is the ground of theoretical reason, but also that theoretical reason provides the concepts for the practical subject's self-reflection, by showing how the human being is essentially a selfdetermining subject. Once a person is aware of his or her freedom, free practical action follows. As Schelling states in Vom Ich, "Give man the awareness of what he is and he will soon learn to be what he ought to be. Give him the theoretical self-respect and the practical will soon follow" (67/1:157). He attempts to do so by incorporating Jacobi's demand for an immediate insight of the supersensuous world into systematic philosophy. As we will see, the name of this principle will be intellectual intuition. But we must first turn to Fichte.

\subsection{Fichte's Science of Knowledge}

Although we began our study with a discussion of Jacobi's influence on Schelling, it would be difficult to overestimate Fichte's influence on the young philosopher's work. In a letter to Hegel dated January 6, 1795, Schelling writes, with characteristic bombast,

Fichte, when he was last here, said that one must have the genius of Socrates to fathom Kant. Every day I find this truer. - We must still go farther with philosophy! [...] Fichte will raise philosophy to a height at which most of the current Kantians will dizzily stagger [...] Would I be so lucky to be one of the first to salute the new hero, Fichte, in the land of truth! Blessed be the great man! ${ }^{23}$

The reference to Kant should serve as a reminder that Fichte's own thought was worked out in an attempt to unify the Kantian distinction between the practical and theoretical faculties-

a unification suggested by Kant in the Critique of Practical Reason ${ }^{24}$ - and as a response to the skeptical challenges to the critical philosophy of Kant and Reinhold. Though we cannot

\footnotetext{
${ }^{23}$ AA, III, 1: 15-16.

${ }^{24}$ See Kant's Critique of Practical Reason. Trans. Lewis White Beck (Indianapolis: Bobbs-Merrill Co. Inc., 1956), 94/5: 91. There Kant mentions the expectation that a comparison of the two Critiques would raise the "expectation of bringing some day into one view the unity of the entire pure rational faculty (both theoretical and practical) and of being able to derive everything from one principle. The latter is an unavoidable need of human reason, as it finds complete satisfaction only in a perfectly systematic unity of its cognitions."
} 
develop these themes here, Fichte's early work attempts to derive both theoretical and practical reason from a common principle, which, in turn, will allow critical philosophy to overcome the skeptical objections leveled at it. ${ }^{25}$ This principle is the absolute I.

Yet this interpretation of Fichte cannot be granted as obvious. Within contemporary secondary literature, there is much contention regarding the aims and accomplishments of Fichte's Science of Knowledge. First, some argue that Fichte's first principle involves claims about theoretical content, ${ }^{26}$ others argue for the primacy of the practical nature of the subject $^{27}$, and some argue that it implies important theoretical and practical claims ${ }^{28}$ (or, even, that these implications cannot be decided in the version of $1794^{29}$ ). Then, there are other arguments concerning whether Fichte's goal of unifying theoretical and practical reason in the first principle is accomplished in the Wissenschaftslehre of 1794 or later. Finally, there are also arguments over the degree of continuity between the various presentations of the Wissenschaftslehre. ${ }^{30}$ We need not address the final question as it is beyond our scope, but it is relevant to our inquiry whether or not Fichte presents a first principle that is both theoretical and practical in the presentation of the Science of

\footnotetext{
${ }^{25}$ Frederick Neuhouser discusses these developments within the framework of Fichte's early unpublished writings on Kant. See Fichte's Theory of Subjectivity (Cambridge: Cambridge University Press, 1990), 11-31. Beiser underlines the importance of these skeptical objections to Fichte's development in German Idealism: The Struggle Against Subjectivism 1781-1801 (Cambridge, Mass., Harvard: 2002), 240-259. Concerning the "Review of Aenesidemus," see Daniel Breazeale, "Fichte's Aenesidemus Review and the Transformation of German Idealism," in The Review of Metaphysics 34 (1981), 545-568.

${ }^{26}$ See Dieter Henrich, Between Kant and Hegel. Ed. David S. Pacini (Cambridge, Mass.: Harvard University Press, 2003), 231-262, 279; and Robert B. Pippin, Hegel's Idealism: The Satisfactions of Self-Consciousness (Cambridge: Cambridge University Press, 1989), 42-59.

${ }^{27}$ See A.J. Mandt, "Fichte's Idealism in Theory and Practice," in Idealistic Studies, Vol. 14:2 (May 1984), 127147.

${ }^{28}$ See Beiser, German Idealism: The Struggle Against Subjectivism 1781-1801, 273-288, and Daniel Breazeale, "The Theory of Practice and the Practice of Theory: Fichte and the "Primacy of Practical Reason,"' in International Philosophical Quarterly, Vol. 36:1 (March 1996), 47-64.

${ }^{29}$ Neuhouser, Fichte's Theory of Subjectivity, 44-45.

${ }^{30}$ Note that the various commentators listed in the previous four footnotes often hold different positions about the relationships between these various questions.
} 
Knowledge with which the young Schelling was familiar. ${ }^{31}$ I will argue that, whether successful or not, Fichte articulated a version of his first principle that was intended to be both theoretical and practical: he provides a theory of practical action grounded in a practical subject who infinitely strives to realize the regulative ideal of an absolutely unconditioned self, which in turn demonstrates the ideal foundation of theoretical reason.

In this section, we will focus on the exposition found in the first part of the The Science of Knowledge, where Fichte posits the fundamental principles of what he claims is a complete critical philosophy. The premier part is notoriously difficult and condensed, due in part to Fichte's writing style, but also to the fact that his principles have methodological, ontological, ethical and epistemological consequences: Fichte first details the dialectical method to be utilized in the subsequent parts of the work, postulates the existence of the selfdetermining subject, and argues that the absolute I has a regulative status, as an ethical ideal, within the Grundlage and not a constitutive status. In addition, he attempts to ground formal logic within his transcendental logic and to deduce several of the Kantian categories in establishing the three principles of the system..$^{32}$ Despite the obscurity, Fichte himself conceived of the project of the Wissenschaftslehre as, in Frederick Beiser's words, a "dialectic of consciousness by which the ego comes to recognize for itself what has been postulated and hypothesized by the philosopher." 33

To discover the first principle of the Wissenschaftslehre, Fichte attempts a regressive transcendental analysis, which leads from a fact of consciousness to the condition that makes

\footnotetext{
${ }^{31}$ I am referring to the first part of the $S K$. We know from a letter to Niethammer, dated January 22, 1796, that he had not yet read the practical section. See AA, III/1: 40 .

${ }^{32}$ For a discussion of Fichte's dialectical method and its use of formal logic, see Seebohm, "Fichte's Discovery of the Dialectical Method," 17-42.

${ }^{33}$ Beiser, German Idealism: The Struggle Against Subjectivism 1781-1801, 247. Fichte discusses this in Concerning the Concept of the Wissenschafislehre, 127-133.
} 
such a fact possible. As such, the first principle cannot be found amongst the facts of consciousness, but it must ground any possible fact. The first proposition, which demands universal assent, is the principle of identity: $\mathrm{A}=\mathrm{A}$. The principle is asserted absolutely for no proof can be given for it. Nor does $\mathrm{A}=\mathrm{A}$ assert the existence of $\mathrm{A}$; Fichte states that the principle of identity is expressed in the conditional tense: if A then A. Thus, as conditional, $\mathrm{A}=\mathrm{A}$ cannot serve as the first principle of philosophy. But as conditional, it establishes a necessary connection (designated as $\mathrm{X}$ ) between the antecedent and consequent, which is absolute. The next step in Fichte's argument inquires into the condition in which A would exist. The importance of the principle of identity becomes clear at this point. The inquiry regarding the necessary connection $\mathrm{X}$ is a judgment that takes place in self-consciousness. And the necessary connection X can only be posited in the self and by the self as a law, and because this law "is posited absolutely and without any other ground, must be given to the self by itself alone., 34

Therefore the principle of identity has no other basis than the self. It is the self that makes the judgment of identity (the necessary connection X), and A is posited in the self insofar as $\mathrm{X}$ is posited. That is to say that A exists insofar as it is posited in the judging self, and that within the self there is something uniform and enduring in the self: "hence the $\mathrm{X}$ that is absolutely posited can also be expressed as I $=\mathrm{I} ; \mathrm{I}$ am I." ${ }^{35}$ In positing the principle of identity, the self posits a principle of uniformity and sameness. However, the principle of identity $(A=A)$ is not the same as the proposition $I=I$. Fichte argues that contrary to appearances, the principle of identity is grounded in the activity of the self, that is, the self's activity of positing itself. This opens Fichte's argumentation to charges of circularity,

\footnotetext{
${ }^{34} S K, 95 / 1: 94$.

${ }^{35}$ SK, $96 / 1: 94$.
} 
because the principle of identity was first proposed as the starting point in the search for the first principle $(I=I)$, which he now claims is grounded in self-identity. And Fichte acknowledges the circularity at the outset. But a sympathetic reading-without which we will never get to Schelling- would grant that the transcendental self's activity grounds all particular activities of empirical consciousness, so Fichte chose "the shortest road" to demonstration of the positing self. ${ }^{36}$ As absolutely self-posited, the 'I am' posits "the pure character of activity as such, in abstraction from its specific empirical conditions." ${ }^{37}$ The self-positing itself is both the agent and product of activity. Here Fichte breaks with philosophical tradition: the self is an act and not a substance. ${ }^{38}$ As he states, in a manner that anticipates Jean-Paul Sartre, the self is a being "whose being or essence consists simply in the fact that it posits itself as existing." 39

Fichte understands this first principle to be an advance over both dogmatic philosophy and Kantian philosophy. First, dogmatic philosophers, such as Spinoza, ground the self in a thing outside the self (in this case God). According to Fichte, in attributing the "highest unity in human cognition" to God, Spinoza sought to prove a practical need through theoretical reason. This point underlines the regulative status of the absolute $I$ in the Grundlage: the absolute self is a regulative ideal to be sought in practical action. Spinoza's mistake occurred when "he claimed to have established something as truly given, when he was merely setting up an appointed, but never attainable, ideal. ${ }^{, 40} \mathrm{We}$ will return to the contrast between criticism and dogmatism after elucidating Fichte's other two principles.

\footnotetext{
${ }^{36} S K, 94 / 1: 92$.

${ }^{37} S K, 97 / 1: 96$.

${ }^{38}$ Beiser, German Idealism: The Struggle Against Subjectivism 1781-1801, 281-282.

${ }^{39} \mathrm{SK}, 98 / 1: 97$.

${ }^{40} S K, 101 / 1: 101$.
} 
Second, Fichte sees his position as an advance over the 'letter' of Kant by providing the systematic unity sought by Kant but never explained (we are concerned at this point with how Fichte sees his own project; we must leave aside the fact that, in developing the Wissenschaftslehre, Fichte also breaks with the spirit of Kantian philosophy). This unity is found in the absolute I: one can derive the complete system from the first principles, and by conceptualizing the self in terms of practical action, one also unifies the faculties; finally, the justification for this first principle is moral, insofar as it provides an ideal for the striving subject.

But to complete the 'logic' of the Science of Knowledge, Fichte provides two additional principles: that of opposition, and that of grounding. According to Fichte, these principles are already presupposed in the first principle, and though as an act of selfconsciousness they are simultaneous, they can be distinguished through philosophical reflection. ${ }^{41}$ The principle of opposition is unconditioned in form and conditioned in content. Fichte again begins with a fact of consciousness that should be universally accepted: ' $\sim \mathrm{A}$ is not equal to $A$.' If one asserted that ' $\sim A=\sim A$ ' then the proposition would only be a variation of the principle of identity, and it could not explain the act of opposition in its form. Instead, the act of opposition is absolute and unconditional in its form. But the content of the second principle relies on the first already being posited. The content is conditioned by the first principle because it is counterpositing a term to $\mathrm{A}$. That is, one can only oppose a term to A if $\mathrm{A}$ is already posited. ${ }^{42}$

\footnotetext{
${ }^{41}$ SK, 108/1: 109.

${ }^{42} S K, 104 / 1: 104$. Fichte states "The form of $\sim \mathrm{A}$ is determined absolutely by the act; it is an opposite, because it is the product of an opposition. Its matter is governed by $\mathbf{A}$; it is not what $\mathbf{A}$ is, and its whole essence consists in that fact."
} 
As in the first principle, the proposition ' $\sim \mathrm{A}$ is not equal to $\mathrm{A}$ ' is not the proposition of the principle, just as ' $\mathrm{A}=\mathrm{A}$ ' is not ' $\mathrm{I}$ am I.' Just as the positing of $\mathrm{A}$ requires the act of self-positing, the positing of $\sim \mathrm{A}$ in opposition to $\mathrm{A}$ requires a transcendental basis: the notself. Formally, the not-self is in absolute opposition to the self, but in content, it relies on the self. According to Fichte, the not-self grounds the principle ' $\mathrm{A}$ is not equal to $\mathrm{A}$,' which in the dialectical method is the principle of opposition, and as a specific activity of selfconsciousness, provides the category of negation. Yet the not-self cannot be abstracted from representations, but must first be grounded in the self before any object can be opposed to the self. As Fichte states, "in order to set up something as an object, I have to know this already; hence it must lie initially in myself, the presenter, in advance of any possible experience." ${ }^{, 43}$ Therefore, the content of opposition cannot be represented without the positing of the self. But this puts Fichte in a predicament regarding the unconditional form of the principle of opposition: the not-self must be absolutely opposed to the self..$^{44}$ To resolve this difficulty, Fichte introduces the third principle, the grounding principle.

The form of the third principle is determined by the first two principles, but its content is unconditioned. Thus the content of the third principle will provide the first synthetic judgment of the Wissenschaftslehre. In Fichte's terms, the task for action is provided by the first two principles, but its resolution is not. ${ }^{45}$ I have already alluded to the problem posed by the first two principles: if the not-self is posited, then the self cannot be posited, and vice versa. But the not-self can only be posited insofar as the self posits itself. This presents the problem to be resolved by the third principle: because, in their form, both the self and not-self are unconditional, positing the not-self annuls the self, and yet, the not-

\footnotetext{
${ }^{43} S K, 105 / 1: 105$.

${ }^{44} S K, 104 / 1: 104$.

${ }^{45} S K, 106 / 1: 105-106$.
} 
self requires the self in order to be set in opposition. Without a third principle, it seems that there are only two conclusions: a) in positing the not-self, the self is nullified; and b) in positing the not-self, the self must already be posited, which nullifies the not-self.

It appears that to accept both conclusions, the self must be equal to the not-self, which then eliminates the identity of consciousness. If this is the case, the absolute foundation of philosophy is negated. Therefore, the task for action is to find a relation "by means of which all these conclusions can be granted as correct, without doing away with the identity of consciousness. ${ }^{46}$ The third principle resolves the task by introducing a synthesis of the first two principles through limitation: they act on each other by mutual limitation. If both the self and not-self are limited, then they can both be posited in the self: the self is not posited in the measure that the not-self is also posited. Hence the form of the grounding principle is expressed by Fichte as such: " $\mathrm{A}$ is in part $=\sim \mathrm{A}$."47

The third principle answers the primary question of Kant's first Critique ("how are synthetic judgments a priori possible?") by demonstrating a synthetic judgment through positing the limitability of the self and not-self. All further synthetic judgments will be methodologically grounded in the first synthesis in order to be established as valid. The task of the remainder of the theoretical discourse of the science of knowledge is to find the point of conjunction between opposites in a higher ground (a synthesis), which is itself grounded in a higher synthesis. The one exception is the original thesis of self-positing the unity of consciousness. Therefore, the dialectical method applied in Part One of the Grundlage differs from the remainder of the deductions in one important regard: in opposing a not-self

\footnotetext{
${ }^{46} S K, 107 / 1: 107$.

${ }^{47} S K, 110 / 1: 111$.
} 
to the absolute self, the latter is "degraded into a lower concept." ${ }^{48}$ Every other synthesis will be grounded in a higher synthesis. The form of the system is based on this highest synthesis, and the possibility of the system is based on the absolute thesis. ${ }^{49}$

In establishing the foundation of the science of knowledge, Fichte has foreshadowed the necessity of practical philosophy: by introducing a limitation into the self, he has put the identity of the self into question; the limited self is not identical to the absolute self. It is practical action which will attempt to resolve this contradiction within the self: the finite self ought to strive for absolute unconditionality. Again, despite the format of his presentation, Fichte claims that practical reason makes theoretical reason possible. Theoretical reason is no less important, however, as practical reason relies on the theoretical in order to conceptualize practical principles. ${ }^{50}$ But, the absolute I is not only theoretical or practical, it is both the ground of theoretical reason and, as a regulative ideal, a practical principle. ${ }^{51}$

With the foundational principles established, we can now turn to the differences between criticism and dogmatism. Fichte understands dogmatism and criticism as the only two possible systems of philosophy. Each system is monistic, as it proceeds from an exclusive first principle; that is, philosophy cannot explain the possibility of experience from both an absolute self and a thing-in-itself. Criticism, including the spirit of Kant's philosophy, posits the absolute self as the first principle of philosophy while dogmatism goes

\footnotetext{
${ }^{48} S K, 116 / 1: 119$.

${ }^{49} S K, 114 / 1: 115$.

${ }^{50} S K, 123 / 1: 126$.

${ }^{51}$ The status of the absolute subject in the Science of Knowledge has been the subject of much debate. Insofar as these demonstrations have methodological, ontological, epistemological and ethical consequences, I think that interpreting the absolute subject as either a theoretical or a practical principle rests on a false dilemma. As I have shown, Fichte argues that it is both. Thus there is no reason to attribute a "fundamental inconsistency" to the foundations of the Science of Knowledge as Neuhouser does. See his Fichte's Theory of Subjectivity, 41-53, especially 52. My argument owes much to Beiser, German Idealism: The Struggle Against Subjectivism 1781$1801,273-288$.
} 
beyond the self and posits the thing-in itself as the ground of the self. ${ }^{52}$ In other words, criticism proposes a principle immanent to the self, while dogmatism proposes one transcendent to the self. ${ }^{53}$ Fichte does not admit skepticism as a philosophical stance: it is self-refuting insofar as it systematically denies the possibility of systematic philosophy.

Fichte's treatment of dogmatism vacillates between showing how it is either inconsistent or skeptical and showing how it is a step towards idealism. First, Fichte accuses dogmatism of being unable to justify the thing-in-itself (the not-self) as absolute. Because the thing-in-itself transcends the self, the dogmatist can only presuppose that the thing is absolute, but cannot defend this presupposition. But then, as suggested above, dogmatism posits the thing-in-itself out of practical need: "the feeling that, insofar as it is practical, our self depends upon a not-self that is absolutely independent of our legislation, and is to that extent free." ${ }^{54}$ The dogmatic solution to the feeling of necessity, for Fichte, contains a crucial mistake: because it attempts to solve the problem of the feeling of necessity in theoretical reason instead of practical reason, it subordinates the self to an absolute object of theoretical reason, thus abolishing the activity of the self.

However, Fichte follows this critique by stating that such criticism is unfair to dogmatism: dogmatism has not gone beyond the absolute self; instead, it has never attained the absolute. Spinozism, the most consistent dogmatic system, has advanced only to the second and third principles of the Wissenschaftslehre, but only critical idealism can reach the first principle. Criticism surpasses dogmatism because it recognizes the first principle as a regulative ideal grounded in practical action, and not as an object of theoretical reason.

\footnotetext{
52 This requires Fichte to downplay Kant's use of the thing-in-itself. See Beiser, German Idealism: The Struggle Against Subjectivism 1781-1801, 260-272.

${ }^{53} S K, 117 / 1: 120$.

${ }^{54} S K, 118 / 1: 121$.
} 
Fichte surprisingly states, in this account, that the theoretical section of the Science of Knowledge (save the acknowledgement of the absolute self) which is developed from the second and third principles, is "Spinozism made systematic." $\$ 5$ Critical philosophy completes theoretical philosophy through the addition of a practical ground. By 'including' Spinozism within the theoretical section of the Science of Knowledge, Fichte implies that idealism presents a higher realization of self-consciousness. In other words, Fichte argues that dogmatism is a necessary step to the higher system of criticism, thus subordinating the former to the latter. ${ }^{56}$ Demarcating these differences between dogmatism and criticism allows Fichte to respond to Jacobi's charges that theoretical reason necessarily leads to fatalism. By arguing that practical reason and theoretical reason have a common principle, Fichte shows that freedom and systematic philosophy are not mutually exclusive. As George di Giovanni states,

Fichte was only trying to demonstrate that, far from being detrimental to the cause of freedom, [philosophical reflection] was on the contrary its best expression, and a philosophy based on it the clearest manifesto of the primacy of action and existence over theory that Jacobi had promoted from the beginning. ${ }^{57}$

Yet, as I have argued, where Jacobi's account of practical action was marred by an inconsistent historicism, Fichte argues for a universal and moral ideal- the self-determining subject as the ground of free action.

\footnotetext{
${ }^{55} S K, 119 / 1: 122$.

${ }^{56} S K, 119 / 1: 122$. Incidentally, Kant also says as much about his dogmatic rivals. See the Critique of Pure Reason. Ed. Paul Guyer and Allen M. Wood (Cambridge: Cambridge University Press, 1998), A761/B789: "The first step in matters of pure reason, which characterizes its childhood, is dogmatic. The [...] second step is skeptical, and gives evidence of the caution of the power of judgment sharpened by experience. Now, however, a third step is still necessary, which pertains only to the mature and adult power of judgment, [... which is] the critique of pure reason."

${ }^{57}$ Di Giovanni, "The Unfinished Philosophy of Friedrich Heinrich Jacobi," 114.
} 


\subsection{The Practical Rivalry of Dogmatism and Criticism}

Schelling's Letters offer an early glimpse into his philosophical differences with Fichte, but also their differences in disposition as philosophers. ${ }^{58}$ While their philosophical differences are, at this stage, often ambiguous, their dispositions regarding how to philosophize are quite pronounced. Let us take the case of Spinoza: while Fichte viewed his own system of critical idealism as an antidote to skepticism and Spinozism, Schelling expressed a strong sympathy for Spinoza. In a letter to Hegel, dated February 4, 1795, he states, "Meanwhile, I have become a Spinozist! Do not be astonished. Here is how: For Spinoza, the world (the object as such in contrast to the subject) was All; for me, the $I$ is All." ${ }^{59}$ The rehabilitation of Spinoza puts Schelling at odds conceptually with both Jacobi and Fichte: first, Schelling denies the personal God of Jacobi ${ }^{60}$, and second, he breaks with Fichte by interpreting criticism and dogmatism as two opposed, yet complete, philosophical systems, implying a higher standpoint above criticism, by arguing that the absolute is beyond the subject and object. But Schelling also maintains, like Fichte, that criticism is superior to dogmatism by recognizing absolute freedom as a regulative ideal for practice.

Yet the philosophical disposition of the letter to Hegel, and the Letters, is significantly different from Fichte's. Fichte was notorious for claiming that he was not interested in dialogue with those who did not understand his system, or made strong claims against it from other philosophical perspectives. By contrast, we see in Schelling's work a

\footnotetext{
${ }^{58}$ See also Hans Michael Baumgartner. "The Unconditioned in Knowing: I-Identity-Freedom," in The Emergence of German Idealism. Ed. Michael Baur Daniel O. Dahlstrom (Washington, D.C.: The Catholic University of America Press, 1999), 241-250.

${ }^{59}$ Translated in The Unconditional in Human Knowledge. Ed. Fritz Marti. (Lewisburg: Bucknell University Press, 1980), p. 210, n. 51; AA, III/1: 22.

${ }^{60}$ The letter of February 4, 1795 continues (ibid): "For us, there is no supersensuous world other than the world of the absolute I. God is nothing but the absolute I...Personality comes about through the unity of consciousness, But consciousness is not possible without an object. For God, however, that is, for the absolute I, there is no object at all; otherwise it would cease to be absolute. Therefore, there is no personal God."
} 
willingness to include opposed philosophies to adjudicate their competing claims. Or, as in the case with concepts such as intellectual intuition (which we will discuss below), Schelling draws on various sources to inform his work. I think it is central to Schelling's philosophy that he understood the most comprehensive philosophy as the most true, that is, a true system could account for the full development of reason as it is expressed throughout the history of philosophy (note that, taking in Schelling's tendency to polemic, I used 'comprehensive' instead of 'inclusive').

Hence the Letters attempt to mediate the competing demands of criticism and dogmatism. As often noted, the epistolary form and the Spinozist position of Schelling's anonymous interlocutor makes the Letters resemble a philosophical dialogue with his friend Hölderlin (who we will also discuss in Chapter 2.6). In the fragment now entitled "Urtheil und Seyn," Hölderlin argues that the absolute I cannot be its own ground:

Where Subject and Object are absolutely, not just partially united, and hence so united that no division can be undertaken, without destroying the essence of the thing that is to be sundered, there and not otherwise can we talk of an absolute Being, as is the case in intellectual intuition.

But this Being must not be equated with Identity. When I say: I am I, the Subject (Ego) and the Object (Ego) are not so united that absolutely no sundering can be undertaken, without destroying the essence of the thing that is to be sundered; on the contrary the Ego is only possible through this sundering of Ego from Ego. How can I say 'I' without self-consciousness? But how is self-consciousness possible? Precisely because I oppose myself to myself; I sunder myself from myself, but in spite of this sundering I recognize myself as the same in opposites [...] So identity is not a uniting of Subject and Object that takes place absolutely, and so Identity is not equal to absolute Being (HSA, 4: 226-227) ${ }^{61}$

It has often been assumed that Hölderlin is criticizing Fichte, but Manfred Frank argues that this fragment is a response to Schelling's Vom Ich, wherein he conflates the absolute I with all Being. As Frank summarizes their central point of contention:

\footnotetext{
${ }^{61}$ Translation by H.S. Harris, Hegel's Development: Toward the Sunlight 1770-1801 (Oxford: Clarendon Press, 1972), 515-516.
} 
The material unity of that as which we experience ourselves in selfconsciousness is thus contradicted by the duality of the form of judgment we use to express this unity. But there is such an experience of unity (and not only the duality of judgment). And so we must presuppose a unified Being, and we can render the epistemic self-relation as self-relation comprehensible...only if we think of it as the reflex of this unified Being. ${ }^{62}$

While Frank hesitates to identify Hölderlin's 'Being' with Spinoza's substance (he claims that 'Being' is not a first principle like Fichte's absolute I) ${ }^{63}$, it is possible that Schelling did. If the Letters is a response to Hölderlin, it is difficult to tell whether Schelling took Hölderlin's position to be positing an absolute that grounds both subject and object, but which itself is neither (for, here, we are on the path to absolute idealism; see Chapter 4), or as another Spinozist objection to criticism. We can find both possible interpretations in the Letters: when Schelling argues that criticism is practically superior to Spinozistic dogmatism, it is because critical practice infinitely strives to realize the absolute, which is (implicitly) neither subject nor object.

To rehabilitate Spinoza, Schelling distinguishes Spinoza's work from other types of dogmatism. ${ }^{64}$ According to Schelling Spinoza recognized the primacy of praxis, despite presenting a systematic philosophy that has the thing-in-itself (absolute object) as its first principle. So, while Leibnizian-Wolffian School also posits the Object as first principle it does not recognize the primacy of praxis, which is why, Schelling argues, that it was refuted

\footnotetext{
${ }^{62}$ Manfred Frank, The Philosophical Foundations of Early German Romanticism. Trans. Elizabeth MillánZaibert (Albany: SUNY Press, 2004), 107. See also Frank's Eine Einführung in Schellings Philosophie (Frankfurt: Suhrkamp, 1985), 61-70. Jean-François Marquet, by contrast, suggests that Schelling might have influenced Hölderlin, in Liberté et existence. Second Edition (Paris: Les Éditions du Cerf, 2006), 73.

${ }^{63}$ Dieter Henrich argues that Hölderlin's argumentation is Spinozist. See "Hölderlin on Judgment and Being," in The Course of Remembrance and Other Essays on Hölderlin. Ed. Eckart Förster (Stanford: Stanford University Press, 1997), 71-89.

${ }^{64}$ Due to an editorial interference, the first installment of the Letters utilized the term Dogmaticismus (dogmaticism) in the place of Dogmatismus (dogmatism). In the Fifth Letter, Schelling distinguishes between the two by stating that Kant had refuted dogmaticism, that is, the metaphysics of the $18^{\text {th }}$ century, such as Wolff and Leibniz. See Letters, 169/1: 302; and Klaus Duising, "The Reception of Kant's Doctrine of the Postulates in Schelling's and Hegel's Early Philosophical Projects," in The Emergence of German Idealism. Ed. Michael Baur Daniel O. Dahlstrom (Washington, D.C.: The Catholic University of America Press, 1999), 206-207.
} 
by the Critique of Pure Reason. But more pernicious than this form of dogmatism is that of the Tubingen Stift, including the professors Gottlob Christian Storr and Johann Friedrich Flatt, the so-called proponents of criticism who use Kant to re-introduce the relics of precritical philosophy. ${ }^{65}$ Schelling had firsthand experience of this tendency, as he was in residence there as he wrote the Letters, which no doubt explains why their original publication was anonymous. As he writes from Tübingen to Hegel, on Epiphany (January 6, 1795),

All imaginable dogmas have been stamped as postulates of practical reason and wherever theoretical and historical proofs are lacking the practical Tübingian reason cuts the knot. You can see with glee the triumph of these philosophical heroes. [...] It is a pleasure to watch them pull the string of the moral proof. Before you know it, the deus ex machina pops up, that personal individual being who sits up there in heaven! ${ }^{66}$

Schelling's central objection is that the Tübingen School misuses the practical postulate of God; instead of interpreting the idea of God as an "object of action," they understand it as an object "considered as true" (159/1: 288). But the acceptance of truth can only take a theoretical form. Therefore, they have confused the domains of theoretical and practical reason. From practical need, they re-introduce theoretical truth. As Klaus Düsing notes, they "weakened and falsified the concept of [Kant's] practical postulates in that they declared every possible claim containing theoretical, even empirical, representations to be a postulate of practical reason merely insofar as a moral-practical interest or need was served thereby. ${ }^{967}$ This, according to Schelling, is inconsistent from both the theoretical and practical

\footnotetext{
${ }^{65}$ For an illuminating essay on Storr and Flatt see Dieter Henrich's "Dominant Philosophical-Theological Problems in the Tubingen Stift During the Student Years of Hegel, Holderlin, and Schelling," in The Course of Remembrance and Other Essays on Hölderlin. Ed. Eckart Förster (Stanford: Stanford University Press, 1997), 31-54.

${ }_{66}^{66}$ Translated in The Unconditional in Human Knowledge. Ed. Fritz Marti. (Lewisburg: Bucknell University Press, 1980), p. 200, n. 5/AA, III, 1: 15-16.

${ }^{67}$ Klaus Dusing, "The Reception of Kant's Doctrine of the Postulates in Schelling's and Hegel's Early Philosophical Projects," 203-204.
} 
perspectives: first, it re-introduces absolute causality into theoretical reason, and second, it introduces an absolute object into practical reason.

The latter objections are adapted from Kant. In the preface to the second edition of the Critique of Pure Reason, Kant addresses the inclusion of the practical postulates within the domain of theoretical reason. There he states that it is not possible to postulate God, freedom and the immortality of the soul for practical reason without simultaneously depriving theoretical reason "of its pretension to extravagant insights." 68 Since theoretical reason only deals with objects of possible experience, attempting to introduce the practical postulates into theoretical reason would reduce them to mere appearances. The importance of the postulates is that they are not just appearances but morally necessary. So Kant draws the conclusion that the dogmatic inclusion of practical reason within theoretical reason is the "true source" not of faith, but of unbelief. Yet morality is also endangered by introducing the cognition of the postulates into practical reason. As Kant states in the Critique of Practical Reason, if human subjects had theoretical knowledge of the postulates, then "God and eternity in their awful majesty would stand unceasingly before our eyes," and the reason for moral action would be constantly present and external. ${ }^{69}$ Practical action would no longer be autonomous, or done for the sake of the moral law, but would be done predominately out of fear. Kant draws the striking conclusion, against dogmatism, that if direct knowledge of God were possible, all human action would be reduced to "mere mechanism," that is, necessity and fatalism. ${ }^{70}$ Here we can see why Schelling objects to introducing absolute, objective

\footnotetext{
${ }^{68}$ Critique of Pure Reason. Ed. Paul Guyer and Allen M. Wood (Cambridge: Cambridge University Press, 1998), B xxx.

${ }^{69}$ Critique of Practical Reason, 152/5: 147.

${ }^{70}$ As Kant states in the Critique of Practical Reason, 152-153/5: 147: "most actions conforming to the law would be done from fear, few would be done from hope, none from duty. The moral worth of actions, on which alone the worth of the person and even of the world depends in the eyes of supreme wisdom, would not exist at
} 
causality into practical action, as positing God's causality extinguishes the subject's free causality. After these criticisms of this dogmatic tendency, however, Schelling's accord with Kant reaches its limit, as Schelling refutes the other forms of dogmatism in order to rehabilitate Spinoza as the most consistent proponent of a dogmatic system of action that can be opposed to criticism. With this opposition, Schelling opens a practical contest between the two opposed systems over human freedom.

Schelling's appropriation of the Critique of Pure Reason is oriented towards grounding the conflict between dogmatism and criticism. This orientation requires overlaying his concerns, Kant's own concerns, and the debates over the status of the thingin-itself within the first Critique. To defend Kant, proponents of critical philosophy were required to navigate between two claims: first, by limiting the understanding to the cognition of appearances, Kant was only repeating Berkeley's idealism; or second, that Kant's utilization of the thing-in-itself was not justified by the tenets of his own critique (the restriction of the inquiry to objects of possible experience); therefore the inclusion of the thing-in-itself within critical philosophy is itself dogmatic.

Schelling's interpretation of the Critique of Pure Reason breaks with this dilemma, and the defense of criticism articulated by Kant and Fichte. Instead of defending Kant's critical system, as a system, Schelling explains his predecessor's inconsistencies by claiming that, far from establishing one system of knowledge, the Critique of Pure Reason "prepares" a canon for both criticism and dogmatism:

the Critique is destined to deduce from the essence of reason the very possibility of two exactly opposed systems: it is destined to establish a system of criticism (conceived as complete), or, more precisely, a system of idealism

all. The conduct of man, so long as his nature remained as it now is, would be changed into mere mechanism, where, as in a puppet show, everything would gesticulate well but no life would be found in the figures." 
as well as and in exact opposition to it, a system of dogmatism or of realism (169/1: 302).

For Schelling, the transcendental subject serves as the first principle for criticism, and the thing-in-itself serves as first principle for dogmatism. As already mentioned, Kant distinguishes critical philosophy and dogmatic philosophy (which Schelling calls dogmaticism) by way of method: the latter utilizes pure reason without inquiring into its limits. Thus Kant views neither the transcendental subject nor thing-in-itself as the exclusive first principle to one of two opposed philosophical systems. Though the transcendental unity of apperception grounds the possibility of objective experience, it must be noted that, for Kant, consciousness of this unity is derived from the representations of inner sense (time) and not from an absolute act. ${ }^{71}$ And although Kant introduces the thing-in-itself in opposition to the transcendental subject, the former remains a "boundary concept" within critical philosophy. ${ }^{72}$ The thing-in-itself, as a concept, serves to limit the domain of sensible intuition to appearances: though it can be thought without contradiction, it cannot be cognized; instead, it functions as a limit to cognition, restricting the understanding to appearances (phenomenon) while remaining agnostic on the ontological status of the noumenal world. Yet, in later sections of the Critique, Kant himself seems to overstep his own critical boundaries when he attributes causality to the transcendental object. ${ }^{73}$

Fichte attempted to resolve the problematic status of the thing-in-itself in his "Review of Aenesidemus," a response to an anonymous critique (written by Gottlob Ernst

\footnotetext{
${ }^{71}$ Critique of Pure Reason, A1 16-117, and in the re-written sections found in B136-140.

${ }^{72}$ Critique of Pure Reason, A255/B310-311.

${ }^{73}$ Critique of Pure Reason, A288/B344. If the thing-in-itself and the transcendental object are different, Kant seems to use them as synonyms in this passage. Later Kant attributes the givenness of space to the transcendental object: see A557/B585.

${ }^{74}$ Fichte, "Review of Aenesidemus," in Early Philosophical Writings. Ed. Daniel Breazeale (Ithaca: Cornell University Press, 1988), 59-77/ I, 3-25. For an account of the importance of this text in Fichte's development,
} 
Schulze, a professor at Helmstadt) of Kant's and Reinhold's critical philosophy from the standpoint of Humean skepticism. ${ }^{75}$ Schulze's criticisms of Kant and Reinhold forced the young Fichte to develop his own critical approach later realized in the Wissenschaftslehre. The primary contention against Kant (we will leave Reinhold aside) was the accusation that Kant's introduction of the noumenal world, through attributing causality to the subject (as a subject who represents) and the thing-in-itself (as the external cause of representations) violated critical philosophy's explicit limits.

Fichte resolves the problematic status of the thing-in-itself by subordinating it to the subject (the I), the self-consciousness which accompanies all representation. Ascribing causality to self-consciousness is defensible because the autonomy of the self is valid for itself (to ask whether this autonomy could be in itself, as Schulze demands, extends beyond possible knowledge). ${ }^{76}$ Then Fichte removes the thing-in-itself from critical philosophy, claiming that the concept of a thing-in-itself not opposed to consciousness is selfcontradictory. Thus, he states, the structure of consciousness is oppositional: consciousness of the self requires something (the not-I) to be thought. While this reply seems to confirm the accusation that Kant's philosophy falls into Berkeley's idealism, Fichte dismisses this possibility by noting that Berkeley was refuted in the "Transcendental Aesthetic" of the first Critique, where Kant argues that space and time are not appearances but pure intuitions that ground all possible experience. ${ }^{77}$

see Daniel Breazeale, "Fichte's Aenesidemus Review and the Transformation of German Idealism," in The Review of Metaphysics 34 (1981), 545-568.

${ }^{75}$ G.E. Schulze, "Aenesidemus (excerpt)," in Between Kant and Hegel: Texts in the Development of PostKantian Idealism. Eds. George di Giovanni and H.S. Harris (Albany: SUNY Press, 1985), 104-135. The full title of the text is Aenesidemus, oder über die Fundamente der von Herrn Prof. Reinhold in Jena gelieferten Elementar-Philosophie.

${ }^{76}$ Fichte, "Review of Aenesidemus," 70-71/I, 16.

${ }^{77}$ Although Fichte does not mention the following, it should be remembered that in the "Transcendental Aesthetic," Kant argues that the transcendental ideality of space and time also implies their empirical reality. 
By contrast, Schelling explains Kant's inconsistencies by claiming that the first Critique had to necessarily establish a common point of reference between criticism and dogmatism: from the perspective of theoretical reason, Kant provides a negative refutation of dogmatism, but being limited to the cognitive faculty, the Critique of Pure Reason could proceed no further; the resolution to the conflict must be sought within practical action. Before turning to the practical solution proposed by Schelling, in which criticism triumphs through the recognition of human freedom, it is necessary to introduce the solution's metaphysical ground, found in neither Kant nor Fichte. For the latter two, criticism is a higher stage of cognition, in which reason recognizes the limits ignored by dogmatism. For Schelling, the two systems are mutually opposed, and the choice of a system requires a decision which itself imposes a theoretical framework. So criticism's superiority is demonstrated through its self-recognition of human freedom. However, in setting the two systems in direct opposition, Schelling implies a common point of dispute, beyond the confines of Fichte's Wissenschaftslehre.

The common point between the two systems implied by "the very concept of philosophy" itself, according to Schelling, is the original opposition resulting in the departure from the absolute. The original opposition provides the respective first principles of the two systems. Schelling is careful to note that Kant's Critique proceeds from the fact of the opposition between the subject and object, and that it does not- and cannot- "ascend" to the absolute as the latter is a regulative ideal of practical reason. However, as the common ground of both dogmatism and criticism, the absolute is not the absolute subject postulated in Fichte's Wissenschaftslehre. The fact of opposition, for Schelling, orients the inquiry of the Critique of Pure Reason. Schelling rephrases the Kantian question of 'how synthetic 
judgments are possible a priori' to ask how the first principle of a philosophical system proceeds toward its opposite: "How do I ever come to egress from the absolute, and to progress toward an opposite?" (164/1: 294). The common point between dogmatism and criticism is this original synthesis. At this point, criticism can demonstrate its theoretical superiority. But it cannot confute dogmatism through theory, because the ultimate tribunal is that of practical reason.

Criticism can refute dogmatism (although not decisively) through the theory of synthetic judgments. Criticism proves, Schelling states, that once the subject judges objectively, it must judge synthetically. However, dogmatism cannot show how absolutely objective cognition is possible, that is, how an absolute object can judge synthetically. Therefore, all cognition is possible only under the condition of the subject (165/1: 296). Yet the first Critique does not end with the theory of synthetic judgments; it also demarcates the boundaries of pure reason: Kant uses the Transcendental Dialectic to show how pure reason overextends its boundaries when it enters the domains of rational psychology, cosmology and theology. In Schelling's terminology, theoretical reason cannot achieve the absolute thesis (the unconditioned ground of the conditional) demanded by pure reason. Or, as Schelling phrases it, in reference to Jacobi, the transition from the infinite to the finite is prohibited by philosophy (which, as we will see in Chapter 4, becomes a central problem of Schelling's identity-philosophy). The absolute, as unconditional, falls outside the limits of theoretical reason because anything that can be said about it is not synthetic but analytic. If synthesis ended in a thesis, it would have to eliminate all that is conditional. But synthesis requires the condition of opposition between subject and object. Theoretical reason seeks an unconditional ideal which it cannot realize: "having formed the idea of the unconditioned, 
and, as theoretical reason, being unable to realize the unconditioned, it therefore demands the act through which it ought to be realized" (167/1:299).

Therefore, insofar as we must resolve these demands, we must move from theoretical to practical philosophy. Here, too, Schelling will argue for criticism's superiority over dogmatism. Before moving to the practical domain, we should complete Schelling's interpretation of the Critique of Pure Reason: his ultimate claim is that the Critique establishes the practical postulates for both criticism and dogmatism. This is why Kant admits the thing-in-itself within transcendental idealism, despite the implication that the thing-in-itself exists as noumenon. This admission is only inconsistent had Kant aimed to found only a system of criticism. However, Schelling claims that the first Critique establishes an exhaustive canon for both systems, comprising the genuine Wissenschaftslehre (ultimately implying that Fichte's Wissenschaftslehre itself is not a complete doctrine of science). Yet, according to Schelling, Kant also establishes that a complete system of philosophy is not an object of knowledge but a goal of practical activity (171/1:305).

Thus in demonstrating that the realization of a system is the goal of activity, Schelling further claims that Kant deduces the ground of the spontaneous activity of philosophy: every philosopher guided by the ideal of a system- whether consciously or unconsciously- practices the realization of his or her system. As Schelling states, each philosopher 'worthy of the name'- Spinoza is the explicit example- lives his or her system. But, a system can only be an ideal for gradual approximation, for a completed system would vanquish free activity. Hence the necessity of two opposing systems: a permanent resolution of their opposition into a complete and actual system of philosophy would extinguish the 
freedom 'lived' in a system of action (172/1: 302). This is yet another criticism of Fichte's claim to have arrived at a complete and systematic doctrine of science.

However, it is important to clarify the conceptual status of this freedom, including its relation to the opposition between dogmatism and criticism. It is in the realm of practice that the philosopher can answer the question of "how the absolute could come out of itself and oppose to itself a world" (174/1: 310$)$. And dogmatism and criticism provide two different answers: the latter asserts the subject's causality through individual's self-recognition of freedom, while the former ascribes absolute causality to the object, subjugating the individual to necessity. The original free act takes place in the choice between systems. Yet the free act is not voluntarist or irrational; for Schelling the relationship between the choice and the system is an "inevitable circle": theoretical reason serves as an anticipation of practical reason. It is practical reason that, through its creative powers, gives reality to theoretical propositions. As Schelling states,

If we want to establish a system and, therefore, principles, we cannot do it by an anticipation of the practical decision. We should not establish those principles unless our freedom had already decided about them; at the beginning of our knowledge they are nothing but proleptic assertions, or, as Jacobi expresses it somewhere-wryly and awkwardly enough, as he says himself, yet not quite unphilosophically- they are original insuperable prejudices [Vorurteile]" (176/1: 312-313).

The reference to Jacobi both establishes his influence on Schelling and serves to distinguish their positions: one cannot assert the dignity of theoretical reason and the importance of Spinoza without reprimanding Jacobi. While for Jacobi, the experience of faith grounds all knowledge, for Schelling practical action imposes a theoretical framework by creating the reality of its principles. At the point of this free choice, the critical philosopher would hold not only that 'I act freely' and that 'I will act freely' but also that 'I will have acted freely.' 
This shows the practical superiority of critical philosophy, as the dogmatist misrecognizes the initial free choice as conditioned by objective necessity.

Fichte's implicit response to Schelling in the "First Introduction to the Science of Knowledge" (1797) has often been cited as a more radical formulation of the choice between dogmatism and criticism, because it ascribes the choice to pre-systematic interests and inclinations. Fichte writes

What sort of philosophy one chooses depends, therefore, on what sort of man one is; for a philosophical system is not a dead piece of furniture that we can reject or accept as we wish; it is rather a thing animated by the soul of the person who holds it. A person indolent by nature or dulled and distorted by mental servitude, learned luxury, and vanity will never raise himself to the level of idealism. ${ }^{78}$

Yet the claim that one chooses a system according to inclination is not more radical than Schelling's vertiginous circle of theoretical anticipation and practical action. Instead, Fichte pits the cool and rational disposition of the idealist against the passions and animosity of the dogmatist. Opposing rationality to passion is, as is well known, a fairly standard discursive trope in Enlightenment and post-Enlightenment philosophy. And after deploying this trope, Fichte claims that the ultimate danger for the idealist would be to break character and show contempt for the dogmatist's inability to recognize the superiority of criticism. By contrast Schelling risks the irresolvable conflict of two rival practical systems.

Yet in the seventh, eighth and ninth letters, Schelling still argues that the dogmatist misrecognizes the initial free choice of practical action through a misinterpretation of the principle of intellectual intuition. The terminology itself should indicate that our young scholar has not returned the first Critique to the bookshelf in order to retrieve the second. Instead, Schelling turns to a modified Fichtean account of practical action (as found in the

\footnotetext{
${ }^{78}$ Fichte, "First Introduction to the Science of Knowledge" in $S K, 16 / 1: 434$.
} 
Science of Knowledge) with the addition of the principle of intellectual intuition. At the time of the publication of the Letters Fichte had yet to publicly develop this principle. Until 1797, the "Review of Aenesidemus" is the only text of Fichte to mention "intellectual intuition."79 Though explicitly prohibited by Kant, Schelling introduced intellectual intuition in Vom Ich. There he argues that the absolute I can be grounded neither in a concept nor an object, but as self-determined in an intellectual intuition, which is the self-attribution of absolute freedom (84-85/1: 180-183). This self-attribution of freedom grounds the identity of the absolute subject, despite the fact that empirical consciousness is constantly threatened by the flux of constant change:

You insist that you should be conscious of this freedom? But are you bearing in mind that all your consciousness is possible only through this freedom, and that the condition cannot be contained in the conditioned? Are you considering in any way that the $I$ is no longer the pure, absolute I once it occurs in consciousness; that there can be no object at all for the absolute I; and, moreover, that the absolute I never can become an object? Selfawareness implies the danger of losing the I. It is not a free act of the immutable but an unfree urge that induces the mutable $I$, conditioned by the not-I, to strive to maintain its identity and to reassert itself in the undertow of endless change (84/1: 180).

In the Letters, Schelling introduces intellectual intuition as the common practical principle between the two systems, and it seems to have its origins in his reading of Fichte, Jacobi's immanent feeling of faith in revelation and Spinoza's intellectual intuition of the infinite. For Spinoza, recall that there are three kinds of knowledge: the kind arising from sensation or imagination, the kind arising from reason and concepts, and the third (intellectual intuition) which proceeds from adequate knowledge of the infinite (God) to the essence of the finite

\footnotetext{
${ }^{79}$ For Snow, this indicates that Schelling influenced, or at least necessitated a response from Fichte in this regard. See Schelling and the End of Idealism, 36-55.
} 
(things) ${ }^{80}$ Because Schelling holds, like Jacobi, that philosophy is prohibited from speculating about the transition from the infinite to the finite, intellectual intuition offers the practical principle that intuits the infinite in the finite (thus reversing Spinoza). But now, the danger of losing the absolute $I$ is not found in the transitory nature of things, but in the enthusiasm of dogmatism. Hence there are two different accounts of intellectual intuition between Vom Ich and the Letters. In the former, intellectual intuition is the Archimedean point preventing the subject from losing itself in the constant changes of the world, while in the latter text, it runs the risk of losing the world by abstracting from the opposition of subject and object.

Dogmatism, and, Schelling adds, all religious enthusiasm (Schwarmerei) and madness, interprets intellectual intuition as an intuition of an absolute object. That is, dogmatism ascribes absolute causality to an object beyond the self, rendering the self passive to the object's causality. Schelling provides Spinoza as an example. Spinoza holds, through a practical decision, that the "finite world is nothing but a modification of the infinite, finite causality merely a modification of infinite causality" (178-179/1: 316). Had the limitations of finite causality been overcome, then the finite would become identical to the infinite. To live this ethics one would have to lose oneself in the absolute, relinquishing one's subjectivity to the causality of external necessity. Schelling claims that this could only be bearable to the dogmatist because he or she falls prey to the delusion that identifies the individual's ego with that of the deity. Even the dogmatist, he claims, cannot annihilate the self when objectifying self-intution, and so the dogmatist self-identifies with the absolute object (182/1: 320-321).

\footnotetext{
${ }^{80}$ See the Ethics, Treatise on the Emendation of the Intellect, and Selected Letters. Trans. Samuel Shirley (Indianapolis: Hackett, 1992), pp. 90, 214 (Scholium 2, prop. 40, Part III and prop. 25, Part V).
} 
This misidentification is not entirely the fault of the dogmatist, for intellectual intuition is abstracted from all objects, allowing for an "infinite expansion" of the self, which risks losing the self. This is not a danger for the empirical self, which finds resistance amongst a world of objects, but it is a danger for intellectual intuition, abstracted from all sensuous intuition. It therefore remains a danger for criticism as well, if criticism attempts to make the object identical to the subject. Therefore, for criticism itself to banish the reproach of fanaticism it must explain the transition from the finite to the infinite while prohibiting the accomplishment of absolute identity between subject and object. Just as dogmatism demands the loss of the subject in the absolute object in the transition from the finite to the infinite, criticism demands the dissolution of the object in the subject. Both of these demands have the same consequence: the resolution of the opposition between subject and object in absolute identity; in this absolute unity, freedom and necessity are identical (189/1: 330$331)$.

To represent the absolute as realizable, or as an object of knowledge, through practical action leads to enthusiasm. We have already seen that Schelling attributes this error to dogmatism. Because criticism shares its practical goal (of attaining an absolute thesis) with dogmatism, it too runs the risk of enthusiasm. However, criticism avoids this risk, and demonstrates its practical superiority over its systematic rival by positing the absolute as a regulative ideal for practical action. That is, critical praxis realizes, and recognizes, itself in an infinite striving toward its goals. It is through infinite striving that the free subject expands its freedom in the world. Through one's own way of being, one can practically exercise one's philosophy. Thus Schelling argues for a different, more extensive conception of the philosophical vocation than Fichte. Where Fichte sought to subordinate the intellectual 
allure of Spinoza within the theoretical section of the Wissenschaftslehre beneath the domain of practical reason, Schelling opened a contest between rival philosophical systems as the agon for practical action. Yet after establishing this rivalry, the Letters formulate a defense of critical idealism even if they do not adhere to Fichte's doctrines. This is the context in which we should read the discussion of Greek tragedy in the tenth letter.

\subsection{The Sublime of Greek Tragedy and the Interests of Reason}

In the final letter, Schelling returns to the theme of an aesthetic side to philosophy, which was introduced in the first. As I have mentioned, recent secondary literature has read the final letter as a bold statement of a philosophy of tragedy superior to both dogmatism and criticism. As Peter Szondi points out, "by not focusing on the effect that the tragic has on the audience" Schelling breaks with the modern tradition of poetics based on Aristotle, and in Germany, Lessing. ${ }^{81}$ However, as Szondi points out, while a philosophy of tragedy, as opposed to a poetics of tragedy, becomes possible after Schelling, the Letters remain committed to the affirmation of practical reason.

In the Letters, Schelling attributes the demonstration of this identity between freedom and necessity (as fate) to the content of Greek tragedy, but he evaluates this content according to the dictates of practical action, specifically the disjunction between the first principles of criticism and dogmatism. Greek tragedy, he concludes, cannot be proposed as a system of practical action because it reintroduces an objective power to limit the absolute freedom demanded by critical philosophy. In terms more appropriate to Sartre, an avowal of tragedy as a system of action allows the emergence of bad faith in the denial of one's

\footnotetext{
${ }^{81}$ Peter Szondi, An Essay on the Tragic. Trans. Paul Fleming (Stanford: Stanford University Press, 2002), 1-3, 7.
} 
freedom. This caveat, prohibiting the use of Greek tragedy for a system of action, introduces ambiguity into Schelling's praise for Greek tragedy, which several recent commentators minimize. ${ }^{82}$ Both Theodore D. George and Jason M. Wirth omit it altogether. ${ }^{83}$ But the exclusion of Greek tragedy as a model for practical action should be understood by the fact that Schelling is defending the practical aspects of critical philosophy, that is, the defense of freedom as conceived by criticism. ${ }^{84}$

In the first letter, Schelling affirms the implied position of his interlocutor: that it is greater to struggle against fate than to flee to the safety of a moral God. Yet Schelling quickly differentiates his affirmation from the dogmatism of his addressee: although consistent dogmatism has an aesthetic side, it is not of struggle against fate but surrender ("Quiet abandonment to the immeasurable..."), as any thought of resistance to fate through the self-assertion (Selbstmacht) of freedom "comes from a system better than dogmatism,"

\footnotetext{
${ }^{82}$ See, for instance, David Farrell Krell, The Tragic Absolute: German Idealism and the Languishing God (Bloomington: Indiana University Press, 2005), p. 183-187; and Leonardo V. Distaso, The Paradox of Existence: Philosophy and Aesthetics in the Young Schelling (Dordrecht: Kluwer, 2004), pp. 105-110. Distaso seems to be reading the concerns of the System of Transcendental Idealism back into the Letters.

${ }^{83}$ Theodore D. George, "A Monstrous Absolute: Schelling, Kant, and the Poetic Turn in Philosophy," in Schelling Now: Contemporary Readings. Ed. Jason M. Wirth. (Bloomington: Indiana University Press, 2005), 135-146; and Jason M. Wirth, The Conspiracy of Life: Meditations on Schelling and His Time (SUNY Press, 2003), 146. George inexplicably ignores the fact that the Letters follows Fichte in demarcating the boundaries of theoretical reason in order to demonstrate the practical vocation of criticism, and that Schelling excludes the tragic as a system of practical action. These omissions appear to be the consequences of attributing several concerns to Schelling that are more recent concerns appropriate to Heidegger. George claims that the Schelling of the Letters argues the following anachronistic positions: 1) the fractured character of reason, 2) the theme of the end of philosophy, 3) attributions of arrogance to systematic philosophy, whether critical or dogmatic, and 4) the ruin of representation (of the absolute). As I have argued, none of these positions are Schelling's. Instead, Schelling argues for 1) the limitation of theoretical reason in order to open the contest to practical reason and the power of freedom, 2) the defense of the term 'philosophy' against Fichte's introduction of Wissenschafislehre in its place (see the footnote at 172/1: 307). In addition, 3) it would be odd to call either dogmatism or criticism arrogant, considering Schelling's sympathy for both Spinoza and Fichte; the problem is not arrogance but the claim that one system could assert that it is the complete system of philosophy; and 4) it would be difficult to accuse criticism of representing the absolute because the absolute remains a regulative ideal. The difference between Schelling and Fichte is that the former seems to reject the identification of the absolute as a subject, although because he maintains that the absolute as regulative ideal their differences remain ambiguous. How George discovers a "failure" of criticism where Schelling sees its superiority (in practical action) over dogmatism confirms that he has read later philosophical concerns into those of the Letters.

${ }^{84}$ In this regard, my interpretation agrees with that of Szondi and also Alan White, Schelling: An Introduction to the System of Freedom (New Haven: Yale, 1983), 24-37.
} 
namely, criticism (157/1: 284). The inner principle of art, Schelling claims, is ultimately opposed to the mechanism of dogmatism. He foreshadows the further development of the Letters in this dense passage:

True art, or rather, the divine (theion) in art, is an inward principle that creates its own material from within and all-powerfully opposes any sheer mechanism [and] aggregation of stuff from the outside lacking inner order. This inward principle we lose simultaneously with the intellectual intuition of the world, an intuition which arises in us by means of an instantaneous unification of two opposing principles and is lost when neither the contest nor the unification is any longer possible in us $(157 / 1: 285)$.

The passivity of the subject and the necessity of fate implied by dogmatism stands opposed to the inner principle of the artwork. However, this inner principle is also lost when criticism tries to end the conflict with dogmatism by attempting to actualize its unconditional causality. The principle of art relies on the contest between fate and freedom.

This opposition to both systems is made explicit when Schelling returns to the question of the work of art in the final letter. Again he affirms a conviction of his interlocutor: that, despite being dispelled by the "light of reason," it remains to be seen if there is an objective power that threatens human freedom. This knowledge, though banished from theoretical reason, remains for Greek tragedy, which, in conformity to his times, he calls the highest in art. Greek tragedy demands the free struggle of the protagonist against the powers of fate, a struggle in which the protagonist must suffer in a testimony to human freedom. Thus in the contest between "human freedom and the power of the objective world...the mortal must succumb necessarily if that power is absolutely superior, if it is fate...That the malefactor who succumbed under the power of fate was punished, this tragic fact was the recognition of human freedom; it was the honor due to freedom" (192-193/1: 336). Thus Greek tragedy realizes what neither criticism nor dogmatism can, the presentation of the absolute (we will return to this point in Chapter 4.4). Yet despite presenting the 
identity of freedom and necessity, Greek tragedy cannot propose a tenable system of action: it would "presuppose a race of titans, and that, without this presupposition, it would turn out to be utterly detrimental to humanity" (194/1: 338). Properly speaking, this knowledge of freedom and necessity is neither theoretical nor practical, but sublime. Though the Greeks are the most faithful to the sublime essence of human freedom, their tragedies cannot provide a system of ethics.

Yet the sublime aspect of tragedy motivates reason to resolve the conflict between freedom and necessity. It is in the interest of reason, Schelling claims, to awaken reason from its dogmatic slumber through the affirmation of the self's freedom. As he states,

"Reason must renounce either an objective intelligible world, or a subjective personality; either an absolute object, or an absolute subject, freedom of will." This antithesis once definitely established, the interest of reason demands also that we watch with the utmost care that it be not obscured again by the sophistries of moral indolence, in a veil which would deceive humanity. It is our duty to uncover the whole deception, and to show that any attempt at making it acceptable to reason can succeed only through new deceptions which keep reason in constant ignorance and hide from it the last abyss into which dogmatism must inevitably fall as soon as it proceeds to the last great question, which is, to be or not to be (194/338-339).

The choice of practical reason is between an objective supersensible world and the subject's freedom. Admitting an objective limit to freedom acts against the self's activity and threatens the self with moral extinction (194/1: 339). By contrast, criticism demands the self to act, to 'Be!' (192/1: 335). It is in the interest of freedom to renounce the supersensible powers of the objective world and assert humanity's capacity for freedom. The task of philosophy, for Schelling, is to expose self-imposed limitations of freedom, and critical idealism's superiority over dogmatism is revealed in its insistence on the autonomy and freedom of the subject. 
Thus Schelling turns, in closing, from the discussion of art to the critical demand that humanity reclaim the creative powers it once "sought in the objective world" (195/1: 339). Although Greek tragedy provides the rule (Regel) for all art (193/1:337), it is in the interest of reason to promote human freedom. Thus, in the Letters, tragedy and practical freedom remain in conflict. It is only later, in the System of Transcendental Idealism, that he fully acknowledges the superior character of artistic production, in distinction to practical action. However, in this latter text, Schelling's interest shifts from the content of Greek tragedy- the mortal struggling against fate- to the form of productive activity exhibited in artistic creation. The Letters, though, are themselves conflicted between a defense of Spinoza's legacy, the practical tenets of critical idealism and the superior yet sublime power of Greek tragedy. As a consequence Schelling hints at a much more expansive account than Fichte of what a doctrine of science (Wissenshaftslehre) can achieve. Soon he will develop a systematic account of a system of transcendental idealism, a nature-philosophy, and a philosophy of art. The Letters anticipate this tripartite structure by showing that the sublime essence of tragedy can be assimilated by neither dogmatism nor criticism, maintaining autonomy from both. 


\section{Chapter 2}

\section{From Nature-philosophy to the "Mythology of Reason"}

\subsection{Nature-Philosophy and the Beginning of the Philosophy of Art}

Hegel once remarked that "Schelling carried out his philosophical education in public" (Werke, 20: 421), a judgment that applies best- less Hegel's condescension- to the period between Schelling's Letters and his System of Transcendental Idealism. In this short time, between 1797 and 1799, Schelling expands the domain of critical idealism to include a philosophy of history, a philosophy of art and nature-philosophy. The unprecedented development of nature-philosophy was Schelling's first distinct contribution to, or most notorious liability within, the field now recognized as German idealism. ${ }^{1}$ In the annals of German idealism it is well known that Fichte and Schelling irrevocably split over the status of nature-philosophy in Schelling's system. Yet what is lesser known, though no less important, is that Schelling initially developed his nature-philosophy as a concrete application of theoretical reason within critical idealism, and that Fichte initially approved of these innovations. ${ }^{2}$ Later, Hegel, who specifically defended Schelling's system from Fichte's

\footnotetext{
${ }^{1}$ Despite being criticized by many later philosophers, nature-philosophy has positively influenced Martin Heidegger and Maurice Merleau-Ponty. See Heidegger, Schelling's Treatise on the Essence of Human Freedom. Trans. Joan Stambaugh (Athens, Ohio: Ohio University Press, 1985), 137-139; and Merleau-Ponty, Nature: Course Notes from the Collège de France. Ed. Dominique Séglard. Trans. Robert Vallier (Evanston: Northwestern University Press, 2003), 36-51.

${ }^{2}$ See the letter, dated October 6, 1797, of Erich von Berger, quoted in Xavier Tilliette, Schelling: Biographie (Paris: Calmann-Lévy, 1999), 48. Claude Piché notes that the two philosophers' views on organic nature are compatible, but Fichte maintains, unlike Schelling, an instrumental view of nature. See "Fichte et la première philosophie de la nature de Schelling," in Dialogue, vol. XLIII, no. 2 (Spring 2004), 211-237.
} 
subsequent criticisms ${ }^{3}$ turned against his nature-philosophy and it is often viewed as the target of Hegel's polemic found in the preface to the Phenomenology of Spirit (some have argued otherwise, but this debate is beyond our inquiry. ${ }^{4}$ Suffice it to say that Hegel's own Philosophy of Nature labors to distinguish itself from Schelling's ${ }^{5}$ ).

Schelling draws on a variety of sources for his arguments in support of his naturephilosophy. Other commentators have shown how Schelling criticizes the reliance on the principle of sufficient reason or mechanical explanations of nature in interpreting the world, through the scientific research of his contemporaries, and in dialogue with Kant's Metaphysical Foundations of Natural Science. ${ }^{6}$ These commentaries also make a significant effort to demonstrate how nature-philosophy, at least initially, adhered to many the scientific practices of the late $18^{\text {th }}$ and early $19^{\text {th }}$ centuries. ${ }^{7}$ Some recent literature has traced the development of nature-philosophy to Schelling's early study of Plato's Timaeus. ${ }^{8}$ I will use a different approach- which argues that Schelling pieced together the various fragments of a nature-philosophy from Spinoza's monism, Leibniz's concept of inner purposiveness, and Kant's concept of teleology, while defending the critical position concerning the primacy of

\footnotetext{
${ }^{3}$ See Hegel's The Difference Between Fichte's and Schelling's System of Philosophy. Ed. H.S. Harris and Walter Cerf. (Albany: SUNY Press, 1977).

${ }^{4}$ See the debate between H.S. Harris, Michael Vater and George di Giovanni in Dialogue, vol. XXVI, no. 4 (Winter 1987), 627-668.

${ }^{5}$ See Hegel, Philosophy of Nature. Trans. A.V. Miller (Oxford: Oxford University Press, 1970).

${ }^{6}$ Kant, Metaphysical Foundations of Natural Science. Ed. Michael Friedman (Cambridge: Cambridge University Press, 2004).

${ }^{7}$ See, for example, Joseph L. Esposito, Schelling's Idealism and Philosophy of Nature (Lewisburg: Bucknell University Press, 1977), and more recently, Michael Friedman's "Kant, Skepticism, and Idealism," in Inquiry, vol, 49, n. 1 (February 2006), 26-43.

${ }^{8}$ See, for instance, Manfred Baum, "The Beginnings of Schelling's Philosophy of Nature," in The Reception of Kant's Critical Philosophy. Ed. Sally Sedgwick (Cambridge: Cambridge University Press, 2000), 199-215 and Leonardo V. Distaso, The Paradox of Existence: Philosophy and Aesthetics in the Young Schelling (Dordrecht: Kluwer, 2004), 37-47.
} 
practical reason- to underline the connection between early nature-philosophy, practical reason, and the philosophy of art. ${ }^{9}$

All of these elements, which are rendered in a more or less systematic form in the System of Transcendental Idealism, are found in either the "Allgemeine Uebersicht der neuesten philosophischen Literatur" published over the course of 1797-1798 in Immanuel Niethammer's and Fichte's Philosophisches Journal, and the Ideas for a Philosophy of Nature of $1797 .^{10}$ In these two texts, Schelling develops, from contemporaneous scientific discoveries and what we might call the fragmentary antecedents found in Spinoza, Leibniz and Kant, a general task for investigating nature: to philosophically justify and demonstrate both an organic idea of nature as a totality and show how the self acts within the world and not opposed to it. This task requires both 1) showing how nature cannot be reduced to a mechanistic series of causes and effects and 2) demonstrating falsity of the dualism between the self and world, which is persistent within philosophy, whether, for example, as the division between thought and extension (Descartes) or noumena and phenomena (Kant). These are the central problems facing a program of nature-philosophy. When Schelling writes "Nature should be Mind made visible, Mind the invisible Nature," the prescriptive character is telling: philosophy has yet to demonstrate, or render visible, the common origins of self-consciousness and nature, but it should, if it is to be a complete and systematic philosophy (Ideas, 41-42/2: 56).

\footnotetext{
${ }^{9}$ All the approaches listed here are not mutually exclusive. Each highlights an important aspect of Schelling's work, and they are compatible because Schelling worked from the premise that a truly universal philosophical system could encompass the largest variety of perspectives and experiences.

${ }^{10}$ Citations from volume 1 of the $S W$ are from the "Survey," while those from volume 2 are from the Ideas. The renamed second edition of the "Survey" was translated as "Treatise Explicatory of the Idealism in the Science of Knowledge (1797)," in Idealism and the Endgame of Theory. Ed. Thomas Pfau (Albany, SUNY Press, 1994), 61-138. The English edition of the Ideas also translates its second edition: Ideas for a Philosophy of Nature. Trans. Errol E. Harris and Peter Heath (Cambridge: Cambridge University Press, 1988).
} 
Therefore, we fill follow Schelling's so-called philosophical education, to show how many arguments found in the System of Transcendental Idealism are anticipated by 1798 . While the influence of Spinoza and Leibniz on Schelling has been duly noted, there is very little commentary that focuses on the respective deductions of the "Survey" and the Ideas." Admittedly, these deductions are brief, incomplete, and at first glance, puzzling. But this does not mean that they are not important. I think by reading these two texts together it is possible to reconstruct how Schelling systematically developed his own philosophical approach, later presented in the much more involved transcendental deductions of the System of Transcendental Idealism. Although Schelling reiterates his commitment to the primacy of practical reason, he departs from Fichte's approach in a significant manner: the 'history of self-consciousness' and the 'natural doctrine of the mind' offer genetic accounts of the natural conditions of self-conscious that bypass the problem of circularity confronted by Fichte in the Science of Knowledge. ${ }^{12}$ The first task of this chapter is to show how Schelling deduces the natural and historical conditions of subjectivity. It is, I think, no coincidence that these new transcendental deductions open his work to new vistas beyond Fichte's epistemological and practical concerns.

Admittedly, Schelling has some difficulty making all the antecedents to his naturephilosophy fit together into a whole. To make these difficulties legible to the reader, I have divided this chapter according to Schelling's concerns. In Section 2.2, I show how Schelling re-enters into the debate about the Kantian thing in itself in order to show the limits of theoretical philosophy. His purpose in re-engaging this debate is to demonstrate the limits of

\footnotetext{
${ }^{11}$ Conceming Spinoza, the literature is vast; pick up almost any book on Schelling and Spinoza appears at some point. Concerning Leibniz, see Alan White, Schelling: An Introduction to the System of Freedom (New Haven: Yale, 1983), 42-49.

${ }^{12}$ Discussed in Chapter 1.4. See $S K, 93-94 / 1: 92$.
} 
theoretical philosophy, in order to make room for an "applied" theoretical science, which is nature-philosophy (Ideas, 3/2: 5). In Section 2.3, I show how Schelling adapts the monism of Spinoza's 'doctrine of the attributes' and Leibniz's 'inner purposiveness' as supplements to the nature-philosophy, to show that just as the self-consciousness is purposive, that both the body and other natural beings can be intellectually intuited as purposive. In Section 2.4, I argue that Spinoza's, and Leibniz's, influence is important to understanding Schelling's sketch of the 'history of consciousness,' when he discusses the organic nature of the self. In Section 2.5, I turn to Schelling's "natural doctrine of the mind" to show how selfconsciousness arises both through intersubjectivity, and through organic purposiveness. In this section I show how Schelling turns to Kant's concept of teleology to underline that all purposiveness is organic and without intention. If there is any kind of 'intention' within nature, it is that of humanity, which developed within nature itself.

As Schelling works out these problems, he continues to expand the range of his philosophy. By the final installment of the "Survey," published in 1798, Schelling adds that a philosophy of art will overcome the divisions between practice and theory, and between freedom and necessity (1:465). I will conclude, in Section 2.6 , by evaluating Schelling's brief references to art and aesthetics in the "Survey" and the Ideas, culminating in his claim from the final installment of the "Survey," that art overcomes the division between freedom and necessity, and unifies a system of philosophy, a position developed in the "Älteste Systemprogramm des deutschen Idealismus."

We will close this chapter with a reading of this "System Program." This curious document, first published in 1917, outlines the general program that anticipates some of Schelling's later positions. I will not argue that Schelling is necessarily the author of this 
document, but I would like to show how this text presents several ideas that will be found in the System of Transcendental Idealism: the author of the "System Program" argues that beauty - taken in a Platonic sense- is the "supreme act of reason" because it unites all ideas, suggesting that an aesthetic sense is highest expression of the self's activity, a kind of ethos beyond mere free activity. In addition, the author argues that this recognition of beauty as the highest idea returns poesy to a higher dignity. The art of poetry, the author writes, possesses a utopian potential insofar as it can dissolve the fractured state of humanity and the conflict inherent in history and philosophy through a mythology of reason that renders philosophy sensuous, so that its truth is recognizable to all.

\subsection{Fichte, Kant, and the Thing in Itself}

Both the "Survey" and the Ideas continue to defend the primacy of practical reason, and in some ways, Schelling's account of Kantian philosophy was now much closer to Fichte's. As we saw in the last chapter, in the Letters Schelling had introduced an original appropriation of the Critique of Pure Reason, which, he claimed, set the terms of the rivalry between criticism and dogmatism, by forcing philosophers to choose between two exclusive first principles, either the self or the thing in itself. By re-interpreting the thing in itself as the ground of the system of dogmatism, Schelling removes the primary target of Kant's skeptical critics from his system. According to Schelling, post-Kantian philosophers either must explain the thing in itself through reference to the self (as did Fichte) or the self by reference to the thing in itself (Spinozist dogmatism). All other systems are skeptical or inconsistent, or are what Schelling calls dogmaticist (they do not distinguish between theoretical and practical philosophy). 
Yet a year later, in the "Survey" and the Ideas, Schelling's position is much more in line with Fichte's, as first sketched in the "Review of Aenesidemus" (See Chapter 1.4) Now Schelling criticizes those who continue to include the thing in itself within transcendental philosophy and boldly claims that a consistent Kantian should hold "that we really know the things as they are in themselves, that is, that between the thing represented and the real object there does not exist any difference (105/1: 404)." On the one hand, this claim is contrary to Kant's stated position, which admits the thing in itself as a problematic concept that can be thought but not cognized, and is without commitment to its ontological status. Yet, on the other hand, Schelling's claim is not necessarily controversial, when he argues that Kant's position still possesses a better explanation for cognition: Kant's transcendental idealism is also an empirical realism (the represented object is simultaneously the real object) whereas transcendental realism, as an empirical idealism (meaning that real objects are altogether different from our representations), cannot explain the relationship between representations and object. Thus while Kant's account supports that of common sense, empirical idealism contradicts it (87/1: 379).

Despite these advantages, Kant's transcendental idealism cannot justify the inclusion of the thing in itself within its system. Or, in Schelling's words, Kant cannot provide the principle for the thing in itself: Kant can only symbolize the supersensible ground of the sensible with the expression "things in themselves," which is a contradiction because it demands that one think the unconditioned [das Unbedingte] through the conditioned [ein Bedingtes] (106/1: 406). ${ }^{13}$ Schelling does not criticize the restrictions that Kant places on

\footnotetext{
${ }^{13}$ Schelling states, "Before Kant, things in themselves were hardly conceived in the particular sense in which he speaks of them. They were merely supposed to constitute the check [Anstoss] that would first rouse the reader from the slumber of empiricism, the [philosophy] that presumes to be able to explain experience with experience [and] mechanics with mechanics" (106/1: 407).
} 
theoretical reason in respect to the thing in itself, but he argues, like Fichte before him, that the problem of the supersensible ground of representation should be solved in practical philosophy. Kant initiates this step by arguing that the autonomy of the will through freedom provides the principle of the self's activity, but he does not complete the solution by showing that the thing in itself is grounded in the self's activity, insofar as he continues to speak of the thing in itself as providing "the substance" for our representations (108/1: 409). In other words, it appears that not only is there a division between subject and object in Kant's work, but also between subject as noumenon and subject as phenomenon, and object as noumenon and object as phenomenon. Yet if the represented object is simultaneously the real object, it is contradictory to continue to assert that the represented object acts as a veil over some other substance (a thing in itself). Schelling notes that Kant suggested that this pair of dualisms need not be the case: "it might well be that the intelligible substrate of matter and thinking were the same" (107/1: 407). ${ }^{14}$ Fichte's merit is to have unified both fields of philosophy in one principle, which is the absolute self; the "real object" can be known because it is derived from the self-activity of the subject.

Yet in a step beyond Fichte, Schelling now asks how a self comes to selfconsciousness within nature. As Dieter Sturma argues, this allows Schelling to ground the self's activity in the organic totality of nature rather than the "logic of immanent circularity

\footnotetext{
${ }^{14}$ For Kant, this unity of thinking and matter is only hypothetical, because it could not be discovered by theoretical philosophy. See, for instance, this passage from the Critique of Pure Reason (B427-428): "The problem of explaining the community of the soul with the body" consists "in the presumed difference in kind between the object of inner sense (the soul) and the object of outer sense, since to the former only time pertains as the formal condition of its intuition, while to the latter space pertains also. But if one considers that the two kinds of objects are different not inwardly but only insofar as one of them appears outwardly to the other, hence that what grounds the appearance of matter as thing in itself might perhaps not be so different in kind [my emphasis], then this difficulty vanishes, and the only difficulty remaining is that concerning how a community of substances is possible at all, the resolution of which lies...outside the field of all human cognition." Translation: Critique of Pure Reason. Ed. Paul Guyer and Allen M. Wood (Cambridge: Cambridge University Press, 1998).
} 
that attaches" to Fichte's account of self-consciousness. ${ }^{15}$ In addition, as I will show, Schelling attempts to demonstrate how self-consciousness arises within nature and how thinking and matter have a common origin. In these texts, Schelling appropriates Kant's concepts of purposiveness and teleology in his argumentation, but also incorporates important themes from pre-critical philosophy: like Spinoza, Schelling argues that thinking and matter are two expressions of the same substance (but for the latter, it is the absolute I), and, more surprisingly, he draws on Leibniz's discussions of inner purposiveness in order to characterize nature's own activity. By acknowledging Schelling's debts to these 'dogmatic' philosophers it becomes possible to understand his brief deductions of the "history of selfconsciousness" and the "natural doctrine of the mind" found respectively in the "Survey" and the Ideas. In these two sketches, Schelling incorporates the insights of Leibniz and Spinoza within the becoming of self-consciousness.

\subsection{Appropriating Spinoza and Leibniz}

It is important to be precise about Schelling's project, and what he thinks Spinoza and Leibniz offer to post-Kantian philosophy. ${ }^{16}$ Schelling's project of including naturephilosophy in transcendental philosophy attempts to show how the self emerges within nature. But, as we will see, this project is plagued by the difficulty of maintaining the self's activity as the first principle of philosophy while at the same time showing how the self emerges in nature as an embodied and organized (innerly purposive) being. Schelling adapts Spinoza's doctrine of the attributes to the self and its activity, and he turns to Leibniz for a

\footnotetext{
${ }^{15}$ Sturma, "The Nature of Subjectivity: The Critical and Systematic Function of Schelling's Philosophy of Nature," in The Reception of Kant's Critical Philosophy. Ed. Sally Sedgwick (Cambridge: Cambridge University Press, 2000), 219.

${ }^{16}$ Note that I am leaving aside questions regarding the accuracy of Schelling's reading of these two philosophers, but I think the general idea can be grasped by calling his reading an appropriation.
} 
concept of inner purposiveness. In addition, Schelling reads both of them as monist precedents to his project; for in rejecting the thing in itself, Schelling rejects any attribution of passivity to the self. The only alternative is to explain the self through its own activity ("Survey": 85-89/1: 376-382 and Ideas, 24/ 2: 32). He claims Spinoza and Leibniz as two important predecessors, although he ultimately criticizes them to make room for naturephilosophy.

In contrast to the Letters, we now find, from Schelling, approbation instead of rejection regarding Spinoza, "who, with complete clarity, saw mind and matter as one, thought and extension simply as modifications of the same principle" (15/2: 20$)$, because Spinoza's doctrine of the attributes proposes that the ideal and the real should be explained as affectations and determinations of ideal reality. ${ }^{17}$ Thus "no separation could occur between actual things and our ideas of them. Concepts and things, thought and extensions, were, for this reason, one and the same for him, both only modifications of one and the same ideal nature" (27/2: 35). The problem for Schelling is that the "one and same ideal nature" is not the absolute self but the infinite One-All.

Spinoza's first principle is still the point of contention, but Schelling's criticism hinges, as it did in the Letters, on the status of intellectual intuition: the "third" kind of knowledge beyond experience and reason. For Schelling, intellectual intuition names the primordial, free activity of the absolute self. For Spinoza, intellectual intuition is externalized in the One-All; it "proceeds from the adequate idea of certain of God's

\footnotetext{
${ }^{17}$ Spinoza states "whatever can be perceived by infinite intellect as constituting the essence of substance pertains entirely the one sole substance. Consequently, thinking substance and extended substance are one and the same substance, comprehended now under this attribute, now under that" (Scholium, Proposition 7, Part II) Translation: Ethics, Treatise on the Emendation of the Intellect, and Selected Letters. Trans. Samuel Shirley (Indianapolis: Hackett, 1992), 67.
} 
attributes to the adequate knowledge of the essence of things." ${ }^{18}$ Spinoza's problem is that he cannot explain how a self can become conscious of itself within the constant succession of representations. According to Schelling, it is only possible to make Spinoza intelligible by substituting the self for the Infinite Substance. In one sense, it seems Schelling is suggesting that Spinoza misinterpreted the act of intellectual intuition, whereas criticism grounded the act in the self. In another sense, it seems, Schelling is suggesting that Spinoza himself did this, in introducing the intellectual love of God in Part V of the Ethics. In any case, the substitution of the finite self for the infinite can explain neither the connection between the finite and infinite nor any transition from the infinite to the finite.

By contrast, Schelling claims, Leibniz attempted to explain the identity of subject and object by proceeding from the finite individual to the Infinite (God). The revival of Leibniz, whose system is Kant's primary target of the first Critique, is one of the more surprising features of the Ideas. ${ }^{19}$ Schelling explicitly dismisses the Kantian criticisms of Leibniz:

There is nothing from which Leibniz could have been more remote than the speculative chimera of a world of things-in-themselves, which, known and intuited by no mind, yet affects us and produces all our representations. The first thought from which he set out was [in Schelling's paraphrase]: "that the representations of external things would have arisen in the soul by virtue of her own laws as in a particular world, even though nothing were present but God (the infinite) and the soul (the intuition of the infinite)" (16/2:20).

Schelling neglects to mention that the 'intuition of the infinite' is precisely what Kant argues is beyond finite cognition (that is, beyond constitutive claims about knowledge), and this stands as a division between the philosophy of Kant and the philosophy of Fichte and

\footnotetext{
${ }_{18}^{18}$ Ethics, proposition 25, part V (page 214).

${ }^{19}$ There is some precedent in Fichte's "Review of Aenesidemus." See Early Philosophical Writings. Ed. Daniel Breazeale (Ithaca: Comell University Press, 1988), 73/1: 19-20. In the "Second Introduction to the Science of Knowledge" Fichte approvingly references Schelling's account of Leibniz. See The Science of Knowledge. Ed. Peter Heath and John Lachs (Cambridge: Cambridge University Press, 1982), 82-83/1: 514-515.
} 
Schelling. The latter two include an intellectual intuition of the self as the first principle of all philosophy. Now, Schelling turns to Leibniz to reinforce the character of the self's absolute activity, and the division between activity and passivity. Schelling's paraphrase, quoted above, is drawn from Leibniz's "New System." 20 There, Leibniz argues that the capacity for representation has its origin in the individual's own activity, and cannot be attributed to external things. Kantians, according to Schelling, are wrong to have attributed a world of things in themselves outside perceptual beings. He argues that Leibniz saw that no external cause can be the origin of the mind's activity, and thus all modifications and representations arise from inner purposiveness. Because Leibniz recognized the monad's (individual self's) inner purposiveness, he could not hold that things were actual in themselves, but are only actual through the self's mode of representation. Leibniz stands in distinction to Kantians who want both the self and things in themselves: "if among ourselves it is said that no representations could arise in us through external causes, there is no end of astonishment. Nowadays it is valid in philosophy to believe that the monads have windows, through which things climb in and out" $(16 / 2: 21)$.

As we will see, Schelling uses this concept of inner purposiveness to argue that the self's activity is itself organically organized in a sequence of overcoming its own selfimposed limitation. Yet, ultimately, Leibniz's account of the self's purposiveness is limited, Schelling argues, by the fact that Leibniz still explains the intersubjective nature of the world through a principle external to the self: pre-established harmony, Schelling argues, asserts that the world is intersubjective (all monads necessarily experience the same series of representations), but does not explain it (i.e. through reference to the self's activity, but

\footnotetext{
${ }^{20}$ Leibniz, "New System of the Nature of Substances and Their Communication, and of the Union Which Exists Between the Soul and the Body (1695)," in Philosophical Texts. Ed. R.S. Woolhouse and Richard Francks (Oxford: Oxford University Press, 1998), 143-152.
} 
through an external principle). Or, in other words, Leibniz interprets the relationship between the self and the world in its being and not its becoming: he explains the relationship as it is, but does not demonstrate how the self becomes conscious of the series of representations as its own activity (29-30/2: $38-40)$. In terms we have already employed: Leibniz grounds his principle in a theoretical principle (God) and not in a practical principle. When Schelling develops an account of intersubjectivity in the Ideas, the concept has a practical basis. It is questionable how much the references to Leibniz add to Schelling's characterization of the self's faculties, especially once the 'pre-established harmony' is removed as an explanation for intersubjectivity. However, Leibniz's 'monadology' lends support to the principle that inner purposiveness- and not just mechanism- characterizes all organized beings in nature. He will fortify these arguments, however inconsistently, with references to Kant's concept of teleology (See Section 2.5).

We are now in a position to show how Schelling appropriates the insights of Spinoza and Leibniz in both the "Survey" and the Ideas. Schelling will adapt their respective insights- the unity of thinking and matter, which we will now specifically refer to as embodiment, and the self's purposive character, by placing them within the becoming of self-consciousness. In doing so, we can show that these two texts share the common concern of elucidating Schelling's early nature-philosophy within the framework of critical philosophy. 


\subsection{The History of Self-Consciousness}

In the "Survey," Schelling introduces what he calls a "history of self-consciousness", which provides a genetic account of the self's activity from intellectual intuition to the will. ${ }^{21}$ This departs from Fichte's approach in a significant manner: the 'history of selfconsciousness' and the 'natural doctrine of the mind' offer genetic accounts of the natural conditions of self-conscious that bypass the problem of circularity confronted by Fichte in the Science of Knowledge. ${ }^{22}$ Dieter Sturma succinctly summarizes their differences:

There is absolutely no need to discover ever new metaphorical ways of supposedly overcoming the logic of immanent circularity that attaches to selfconsciousness. In Schelling's eyes, all that is required is to interpret the transcendental conditions of subjectivity in a developmental and historical fashion. If it is indeed possible to grasp the given and the conditions of subjectivity in terms of a systematic and developmental prehistory of the fact of subjectivity itself, then there can be no pure self-relation on the part of subjectivity in the first place. According to this perspective, human subjectivity is not condemned ceaselessly to move solely within a closed circle of its own. ${ }^{23}$

These deductions anticipate the theoretical section of the System of Transcendental Idealism insofar as they show what he later calls the "transcendental past" of the self: the conditions necessary, but preceding, self-consciousness. ${ }^{24}$ Therefore the use of the term history [Geschichte], like the later use of the 'transcendental past' is a metaphorical expression combining temporal and epistemological determinations. ${ }^{25}$ Although the "history of selfconsciousness" begins with an immediately sensible intuition, it would be a mistake to equate the epistemologically prior with the transcendentally prior: though each successive intuition increases the sphere of the self's activity, and thus, its sphere of cognition, the

\footnotetext{
${ }^{21}$ The following discussion is based on pages 90-98/1: 382-395 of the "Survey."

${ }^{22}$ Discussed in Chapter 1.4. See $S K, 93-94 / 1: 92$.

${ }^{23}$ Sturma, "The Nature of Subjectivity," 219.

${ }^{24}$ The phrase transcendental past is discussed in ST. We will discuss Schelling's later self-interpretation of his concept of the transcendental past in Chapter 3.1.

${ }^{25}$ Sturma, "The Nature of Subjectivity," 224.
} 
deduction regressively leads to the transcendentally unconditional ground, which makes possible all other intuitions, which is the will (presented in an intellectual intuition). While the will is the last in the series of deductions, Schelling argues that intellectual intuition is the highest stage of intuition because it is the only unconditionally free act. All previous stages do not form a temporal sequence, but reciprocally interact within consciousness, and are only divisible by the analyses of the transcendental philosopher (98/1:394). Only willing breaks this reciprocal interaction by an absolutely free act. The latter turns the subject away from objects and toward its will as such, constituting the "supreme condition of selfconsciousness" that grounds both theoretical and practical philosophy.

We are primarily interested in Schelling's deductions of organization and inner purposiveness, in which the self intuits itself as purposive and organized, as, with this intuition, it also intuits itself as embodied and within nature. As we have mentioned, these arguments provide an inventive attempt to overcome the dualisms that plague modern philosophy (mind/body, self/world, thought/extension) while simultaneously arguing for the primacy of the will within systematic philosophy. Although the System of Transcendental Idealism will first make it explicit, the unconscious identity of mind and nature in the self is sundered for the self in reflection and judgment, when the self becomes conscious, requiring, for epistemological reasons, a concept of teleology. So to fill in the next piece of our puzzle, after the 'history of self-consciousness' we will turn to Schelling's development of teleology in the Ideas. The standpoint of reflection needs teleology, but with intuition, Schelling states, for the transcendental philosopher, the "external world lies unfolded for us, so that we may rediscover within it the history of our mind [Geistes]" (90/1:383). 
The self, as Schelling argues, is defined by its productive activity, its constant striving to overcome the limitations of its activity. Therefore, limitations of the self's activity are not one of kind (like, he would claim, the Kantian thing in itself), but one of degree (like Fichte); the stages of self-consciousness follow the expansion of the sphere of the self's activity until it attains self-consciousness. In the System of Transcendental Idealism, he will specifically refer to this activity of the self as unconscious, because the self is not conscious of this activity, although it can be deduced transcendentally. The first limitation of the self is sensation, and the self strives to overcome this limitation by separating itself from the present, and in doing so, intuits itself within a succession of time (and, also, in space). At this stage of the intuition of space and time, the self intuits itself as "nothing but a flux of representations" (91/1: 384). However, these representations are not understood as contingent but external to the self, and as external, they are considered mechanically. The self intuits itself as limited by this external succession.

In striving against this mechanical succession of representations, the self intuits itself as active within the succession. It is at this stage that Schelling introduces the concepts of purposiveness and organization. After the self intuits its striving as productive, but before it becomes self-conscious of its willing as such, it intuits its embodied, organic nature. The self, he claims, not only intuits the succession of representations in time, but also itself as productive within time. If it can intuit itself, though, the self must be able to take itself as an object. Schelling argues that the self intuits itself as productive, and as it can intuit itself as an object that has an organic nature.

The question remains, however, how the self recognizes nature as a living and organic. The "Survey," it seems to me, struggles with conceptual confusion between pre- 
critical and Kantian philosophy. Schelling's 'doctrine of the attributes,' as it were, shows how the self intuits itself as embodied in order to collapse the modern distinction between mind and body, or self and world: the self's own productive activity is intuited as both purposive and embodied, within nature. The self's production is not mechanistically determined, but freely determined for itself. In this intuition "the mind [Geist] is lost in matter [and] no differentiation between the two is possible (94/1: 389)." This intuition of embodiment serves as the pivot between the self and the world, but it does not answer how the self comes to self-consciousness. As he states, this stage of consciousness does not explain how the self comes to recognize its body as its own, and as "governed by its own representations (95/1: 390)."

Schelling's argumentation is similar to Spinoza's doctrine of the attributes, in which thought and matter are two attributes of the same substance, but for Schelling the self is substance. The self intuits itself as embodied, but must still come to recognize this body as its own. To recognize its representations as its own, the self must proceed through the additional stages of abstraction, judgment and finally, willing, which we will leave aside in our discussion.

In the process of arguing for the purposiveness of the self's activity, Schelling provides a brief sketch of nature-philosophy, which grasps nature as organic and productive, irreducible to mechanistic laws. He claims that nature's tendency toward organization reveals a universal productive force that aims to express itself in the archetype of the pure form of the mind (92-93/1: 386-388). Like the self, the totality of nature expresses a principle of inner activity, of organization. An object that contains this inner principle is a living being. As living, each organized being is "virtually removed" from the mechanistic 
series of cause and effect. Each living being, such as a plant, is its own "united world" developing according to its own inner purposiveness, although "according to Leibniz," a confused representation of the world $(93 / 1: 387)$.

The self is distinguished from other living beings because it recognizes itself and acts according to inner purposiveness, and as such, the self is the highest expression of nature. Other living beings, to return to Leibniz, are 'confused' due to their passivity in only being freely acted upon. ${ }^{26}$ For Schelling, the self and the world are living, and while the inner purposiveness is exhibited in the self through its productive capacity, purposiveness is exhibited in the products of living nature: "life constitutes the visible analogue of the mind [Geist] (93/1: 388)." At one point Schelling attributes both a universal Geist, and infinite drive to realize this archetype, to nature. In Kantian terms, he argues that the universal Geist and productive drive are not just regulative, but constitutive for our experience of the world. Schelling will continue to struggle with the status of nature as either, in Kantian terms, constitutive of the self, or as a regulative idea for knowledge, until he inaugurates his system of absolute idealism (See Chapter 4). However, in the Ideas, Schelling addresses the question of how the self recognizes nature as living and organic with explicit reference to Kant's concept of teleology.

\subsection{A Natural Doctrine of the Mind}

In the Ideas, Schelling sketches a "natural doctrine [Naturlehre] of the mind" to make more explicit the interconnection of the self and nature, while arguing that nature-philosophy- as a philosophy of the natural world as totality, which is populated by living, organic (organized)

\footnotetext{
${ }^{26}$ Leibniz, "Monadology," in Philosophical Texts. Ed. R.S. Woolhouse and Richard Francks (Oxford: Oxford University Press, 1998), 274.
} 
beings- is possible within a system of critical idealism. This includes defending the concepts of purposiveness and teleology, which he draws from Kant's Critique of the Power of Judgment. In the third Critique, Kant introduces teleological judgments to supplement the "inadequacy" of the use of mechanical laws in the cognition of nature. Kant, as a belated participant in the Pantheism Controversy, would know the pitfalls of articulating a purely mechanistic philosophy of natural science. While his Metaphysical Foundations of Natural Science is restricted to grounding Newtonian physics in an a priori science based in mathematics" ${ }^{27}$, the "Critique of the Power of Teleological Judgment" in the third Critique argues that critical philosophy does not result in a reductively mechanistic account of nature. ${ }^{28}$ Teleological judgments allow the subject to ascribe purposiveness and unity to nature. However, Kant specifies that the use of the concept of purposiveness in researching nature is regulative and not constitutive; that is, purposiveness in nature does not refer to objects themselves, but to subjective judgment. If it were constitutive (determining of objects, even as phenomena), the addition of purposiveness along side mechanical laws would introduce a special causality into nature. Instead, the principle of purposiveness serves as a regulative ideal for research into nature, and more specifically, the subsumption and unification of the manifold of natural laws under universal laws, including the judgment that nature is a totality, which cannot be discovered a priori or through experience. While the pure understanding determines the a priori laws for natural science, it lacks a guideline with

\footnotetext{
${ }^{27}$ Kant. Metaphysical Foundations of Natural Science. Ed. Michael Friedman (Cambridge: Cambridge University Press, 2004), 6/4:470. Kant states "since in any doctrine of nature there is only as much proper science as there is a priori knowledge therein, a doctrine of nature will contain only as much proper science as there is mathematics capable of application there."

${ }^{28}$ I have made use of several secondary sources for this discussion: see J.D. McFarland, Kant's Concept of Teleology (Edinburgh: University of Edinburgh Press, 1970); Henry E. Allison, "Kant's Antinomy of Teleological Judgment" in System and Teleology in Kant's Critique of Judgment. Ed. Hoke Robinson. Southern Journal of Philosophy, Vol. 30: Supplement (1991), 25-42; and Rudolf A. Makkreel, "Regulative and Reflective Uses of Purposiveness in Kant." in System and Teleology in Kant's Critique of Judgment, 49-63.
} 
which it could discover a "thoroughgoing lawfulness of nature or of its unity in accordance with empirical laws. ${ }^{29}$ The principle of purposiveness provides a maxim for the reflective power of reason, and not as an objective principle for the understanding.

Schelling utilizes many of the same arguments, but draws especially on the concept of natural end, or self-organizing being. A thing can be considered a natural end if it is the cause and effect of itself (note that Schelling used these terms in the "Survey" as well). A self-organizing being cannot just be conceived as an aggregate of parts but requires that we recognize the whole as greater than a sum of parts. Purposiveness is important to Schelling for understanding individual natural organisms and the idea of nature as a whole. The unity of nature, and of individual organisms, cannot be derived from matter. Schelling phrases his point to show the limits of mechanistic explanation: unity

is absolutely inexplicable in terms of matter, as such. For it is a unity the concept, a unity that exists only in relation to an intuiting and reflecting being. For there is absolute individuality in an organism, that its parts are possible only through the whole, and the whole is possible, not through assembling, but through interaction, of the parts, is a judgment and cannot be judged at all save only by a mind, which relates whole and part, form and matter, reciprocally (31-32/2: 41-42). ${ }^{30}$

Here Schelling defends Kant's claim that purposiveness is possible only in relation to subjective judgment. Schelling will push this claim further, by claiming that a judgment of purposiveness is not only a judgment of logical possibility, but is also accompanied by a feeling of necessity. He will then ask why the self feels constrained by this judgment (that is, why one natural object seems purposive while other objects do not). This problem will

\footnotetext{
${ }^{29}$ Kant, Critique of the Power of Judgment, Ed. Paul Guyer (Cambridge: Cambridge University Press, 2000), 258/5: 386.

${ }^{30}$ The use of terms such as concept and matter, etc. have their roots Kant's definitions of purpose and purposiveness found in the introduction to the third Critique: "the concept of an object insofar as it is at the same time contains the ground of the reality of this object is called an end [or purpose: Zweck], and the correspondence of a thing with that constitution of things that is possible only in accordance with ends is called the purposiveness of its form." (Critique of the Power of Judgment, 68/5: 180).
} 
ultimately set the task for nature-philosophy. But first, Schelling, like Kant before him, must refute the dogmatic assumption that teleology implies intentionality; in other words, the assumption that purposiveness in nature requires a deity. This way of phrasing the problem allows us to show where Kant and Schelling differ. For the dogmatist, teleology is constitutive; purposiveness is often identified with intelligent causality or design. For Kant, the central problem of the "Dialectic of the Teleological Power of Judgment" in the Critique of the Power of Judgment is to establish the legitimacy of teleology as a regulative ideal, even if it cannot be used to make constitutive claims about purposiveness. This position undercuts the dogmatic assumption that teleology requires a special kind of constitutive causality distinct from mechanism. ${ }^{31}$ While not a dogmatist, Schelling sometimes seems to assert that organization implies a constitutive causality distinct from mechanism, but just as often he explicitly states that judgments of purposiveness are regulative and not constitutive. We will return to this problem below.

Schelling argues against ascribing purposiveness to an external creator, who imprints final causes into things. The external creator is often conceived like an artist, but then the natural product would, like a work of art, have its purpose imparted from without (33/2: 45). If teleology is external to nature then it contradicts any sense of inner purposiveness. ${ }^{32}$ The addition of an external creator to nature does not advance the philosophical understanding of teleology: a finite creator external to nature is not a creator at all, and the idea of an infinite creator external to nature lapses into the quandary Schelling ascribes to Spinoza: the latter cannot explain the transition from the infinite to the finite. An unexpected objection, since

\footnotetext{
${ }^{31}$ On clarifying how Kant demonstrates this dialectic, Allison's "Kant's Antinomy of Teleological Judgment" was especially helpful.

${ }^{32}$ Distaso misreads this passage in the Ideas and reaches the conclusion that for Schelling "God creates the ontological horizon of every teleological possibility that unfolds in ourselves and in our intellect" (The Paradox of Existence, 140). This conclusion clearly contradicts Schelling's idea of inner purposiveness.
} 
Spinoza attempted to refute teleological conceptions of the world, unless we keep in mind that Schelling's alternative to an infinite creator is a producer within nature: the self.

Thus the failure to explain purposiveness externally opens the path to Schelling's alternative: it can be explained through the transcendental subject. After arguing that teleology and purposiveness are not contrary to transcendental inquiry, Schelling attempts to ground these ideas in the transcendental subject in a manner similar to the "Survey": organic nature (purposive nature, in opposition to a purely mechanistic account of nature) is grounded in life, which in turn is grounded in-or has, as its highest principle- the practical subject. But the practical subject is embodied and not essentially separate from nature. In a being organized by such a higher principle, we find the

absolute unification of Nature and freedom in one and the same being. The living organism is to be a product of Nature: but in this natural product an ordering and coordinating mind is to rule. These two principles shall in no way be separated in it, but most intimately united. In intuition the two are not to be distinguishable at all; there must be neither before nor after, but absolute simultaneity and reciprocity between them (36/2: 48-49).

Here again Schelling reiterates the importance of showing how the self is embodied. The self must be a product of nature, but it must also raise itself through self-consciousness and freedom 'above' nature. While Schelling acknowledges that the soul is the name for the mind considered as the principle of life, this gets the philosopher no closer to understanding how we come to the idea of the connection between the soul and the body (note that the question of how the two are connected is dismissed for the same reason that both mechanistic accounts of life and the principle of the life-force are rejected: Schelling holds that it is impossible to provide physical accounts of mental acts. See Ideas, 37-38/2: 49-51). While from a practical view, distinguishing between the two is illegitimate, Schelling holds that they can still be theoretically separated: although the body cannot explain mental acts, 
the capacities of thinking and willing explain how I can come to experience the body as $m y$ body. This is because self-consciousness is known through intellectual intuition. Curiously, Schelling gives a Cartesian demonstration of this principle (even calling it an immediate experience), presenting this intuition in the rhetoric of an immediate first-person experience. ${ }^{33}$ He writes

if there is in me life and soul, the last as something distinct from the body, I can become aware of either only through immediate experience. That I am (think, will, etc.) is something that I must know, if I know anything at all...because I am immediately aware of my own being, the inference to a soul in me, even if the conclusion should be false, at least rests on one indubitable premise, that I am, live, imagine, will (39/2: 50-51).

Although presenting an argument for the immediate character of the intellectual intuition of the absolute self, Schelling manages to open himself to charges of materialism: even if the inference from the immediate premise of self-consciousness (I am, live, imagine, will) to the soul (now, interestingly, not equated with the principle of life) is shown to be false, the premise remains indubitable. I cannot but read this caveat as a defense of transcendental philosophy regardless of the truth of the metaphysic-religious idea of the soul. Yet if transcendental philosophy can explain how the idea of an embodiment is valid for the self, Schelling again asks how an immediate intuition can be acknowledged in other beings. For other humans, this acknowledgement is ethical: I am practically compelled to acknowledge others, and through this my moral existence acquires purpose (39/2: 53-54). ${ }^{34}$

\footnotetext{
${ }^{33}$ Schelling's 'Cartesian demonstration' runs the risk of reducing his position to 1), the problematic idealism criticized by Kant, and/or 2), a theoretical principle instead of a practical principle. Tilliette notes that at the time Schelling was attempting to define a broader sense of the term 'experience.' See "The Problem of Metaphysics," trans. Christopher Doss, in The Emergence of German Idealism. Ed. Michael Baur and Daniel O. Dahlstrom (Washington, D.C.: The Catholic University of America Press, 1999), 257.

${ }^{34}$ This position is also developed by Fichte in his writings on natural right and ethics. It makes a curious first appearance in the theoretical- and not practical- section of the Science of Knowledge. There he states "No Thou, no I: no I, no Thou." See pp. 172-173/1: 188-189.
} 
The same ethical acknowledgement does not apply to other natural things (whether or not they have self-consciousness like humans), because it is impossible to have mediated knowledge of something that can only be valid as immediate. Although they are experienced as natural beings it is impossible to know if they are conscious like humans. And here we return to Schelling's initial problem: the division of mind and matter. Incidentally, he claims that the idea of nature faces a similar problem: the confrontation between purposiveness and mechanism. However, like Kant argued, Schelling claims the two principles are not exclusive: if mechanism ("a regressive series of causes and effects") and purposiveness (simultaneity of causes and effects) are united, "the idea in us of a purposiveness of the whole; Nature becomes a circle which returns to itself, a self-enclosed system." (40/2: 54). By drawing a connection between the theoretical problem of the division of mind and matter and the regulative problem of the distinction between purposiveness and mechanism as explanations of nature, Schelling is blurring the Kantian distinction between faculties, and between regulative and constitutive principles. ${ }^{35}$ As I mentioned above, Schelling also demands that purposiveness should be shown to be necessary, and not only logically possible. Because we necessarily think nature as purposive, the task of nature philosophy is to show that nature necessarily corresponds to the laws of thought, namely, that nature realizes the purposiveness recognized by our thought. As he states,

what we want is not that Nature should coincide with the laws of our mind by chance (as if through some third intermediary), but that she herself, necessarily and originally, should not only express, but even realize, the laws of our mind, and that she is, and is called, Nature only insofar as she does so.

\footnotetext{
${ }^{35}$ Friedman's "Kant, Skepticism, and Idealism" shows how collapsing the distinction between regulative and constitutive principles, in the Ideas, directly confronts skeptical problems concerning the status of the knowledge of life (biology) arising in Kant's work. See especially 33-36. See also Philippe Huneman, "From the Critique of Judgment to the Hermeneutics of Nature: Sketching the Fate of Philosophy of Nature after Kant," in Continental Philosophy Review 39 (2006), 9-13.
} 
Nature should be Mind made visible, Mind the invisible Nature. Here then, in the absolute identity of Mind in us and Nature outside us, the problem of the possibility of a Nature external to us must be resolved. The final goal of our further research is, therefore, this idea of Nature (41-42/2: 56).

Nature-philosophy becomes applied theoretical philosophy based on a demand: 'Nature should be Mind made visible.' This demand is similar to the Fichtean demand of practical reason that reality ought to conform to the self's activity. However, Schelling takes an additional step to separate himself from Fichte's instrumental interpretation of nature. The task of philosophy- a search for a Schellingian doctrine of the attributes- is to show the identity and isomorphism between mind and nature. This will later trouble Fichte, for both its apparent materialism and its denial of the primacy of the absolute self. When their debate about nature-philosophy goes public in 1801 , Schelling explicitly cites Spinoza as his paradigmatic predecessor (See Chapter 4.2). As I have argued, Spinoza's influence explicitly appears at the origins of nature-philosophy, despite all Schelling's precautions of presenting it as an extension of Fichte's critical idealism.

\subsection{Toward a Philosophy of Art}

The irony of Hegel's remark about Schelling undertaking his philosophical development in public is that, for our purposes, the development of his philosophy of art occurs suddenly, with very little precedent. As we have seen, after announcing (in the Ideas) a system constructed around

Theoretical Philosophy $\rightarrow$ Nature-philosophy (with necessity) Practical Philosophy $\rightarrow$ Philosophy of History (through freedom)

in the final installment of the "Survey," he then announces a philosophy of art to overcome the separation between freedom and necessity. And while Schelling does not develop the 
philosophy of art at this point, he does sketch a philosophy of history that ends with a passage that discusses the development of mythology. The purpose of this section is to investigate any precedents to the final part of the "Survey."

I think the "Älteste Systemprogramm des deutschen Idealismus" could be that document. ${ }^{36}$ The authorship of the "System Program", which is written in Hegel's hand (and variously dated between spring 1796 and early 1797), has generated much dispute in the literature concerning Schelling, Hegel and Hölderlin. ${ }^{37}$ Since its publication it has been attributed first to Schelling (by Franz Rosenzweig, who published the document in 1917), then to Hölderlin (by Wilhelm Böhm in 1926), and finally to Hegel (by Otto Pöggeler in 1965), which emboldened H.S. Harris ${ }^{38}$ and discouraged Xavier Tilliette, who deleted a discussion on the "System-program" from his Schelling, Une philosophie en devenir. Later, in 1973, Tilliette published a forceful rejoinder to Pöggeler. ${ }^{39}$

I myself initially hesitated to include the "System Program" in the development of Schelling's philosophy of art, plagued by the same doubts that Tilliette recalls, but now I think that attributing the authorship to Hegel warrants a strong skepticism and that Schelling and Hölderlin remain contenders (imagine if the document were discovered in Hölderlin's or Schelling's hand. Would we today still be having this debate?). In any case, it is not my intent to prove decisively the authorship of the "System Program" (which would require refuting Hegel and Hölderlin as alternatives). Instead, I would like to present the "System-

\footnotetext{
${ }^{36}$ For a critical edition I have used the version found in Christoph Jamme and Helmut Schneider, eds. Mythologie der Vernuft (Frankfurt am Main: Suhrkamp, 1984), 11-17.

${ }^{37}$ For a brief account in English, see David Farrell Krell, The Tragic Absolute: German Idealism and the Languishing God (Bloomington: Indiana University Press, 2005), 16-26. I also rely on his English translation. ${ }^{38}$ H.S. Harris, Hegel's Development: Toward the Sunlight 1770-1801 (Oxford: Clarendon Press, 1972), 249257.

${ }^{39}$ Xavier Tilliette, "Schelling als Verfasser des Systemprogramms?" in Das älteste Systemprogramm. Ed. Rüdiger Bubner (Bonn: Bouvier Verlag Herbert Grundmann, 1973), 35-52. More recently, Manfred Frank has attributed- with plenty of precautionary remarks- this document to Schelling. See Manfred Frank, Der kommende Gott: Vorlesungen über die Neue Mythologie. Vol. 1 (Frankfurt: Suhrkamp, 1982), 153-155.
} 
program" as an intermediate step in Schelling's development of his philosophy of art. I will argue that the latter half of the document sketches in nuce the system developed in the System of Transcendental Idealism.

It might have been possible, and it would be less controversial, to attribute the development of the philosophy of art to biographical details in his life, except that the editors of the Historisch-Kritische Ausgabe of Schelling's work have established that the final installment of the "Survey" was written before his involvement with the Jena circle and his visits to the galleries in Dresden. About the latter, he recalls to his parents the "divine paintings of Raphael and Correggio" and the "vivid [lebendigen] statues of the ancient world" (the letter is dated September 20, 1798. $A A, \mathrm{IIL} / 1$ : 191). One gathers that these experiences only confirmed his philosophical intuitions.

Even if his philosophy of art predates his interactions with the Jena circle, no matter who wrote the "System-program," we can see the unmistakable influence of Hölderlin. Aside from their correspondence, Hölderlin and Schelling met in July-August, 1795 and December, 1795 in Tübingen, and Frankfurt in 1796. We can establish that Hölderlin, through the influence of Friedrich Schiller, sought to develop an aesthetic solution to the problems of Kantian and Fichtean critical philosophy as early as October 1794 (see the letter to Neuffer, dated October 10, HSA 6: 149-150)..$^{40}$ Then, on February 24, 1796, he writes to Immanuel Niethammer:

I want to discover the principle which explains to me the divisions in which we think and exist, yet which is also capable of dispelling the conflict between subject and object, between our self and the world, yes, also between reason and revelation,- theoretically, in intellectual intuition, without our practical reason having to come to our aid. For this we need an aesthetic sense [ästhetischen Sinn], and I will call my philosophical letters "New Letters on

\footnotetext{
${ }^{40}$ We have already seen the influence that he had on Schelling's Letters in Chapter 1.
} 
the Aesthetic Education of Man." Also, I will move in [these letters] from philosophy to poetry and religion.

And then, I think not incidentally, he continues:

Schelling, whom I saw before my departure, is happy to participate in your journal and to be introduced by you to the learned world. We did not always speak in agreement, yet we agreed that the new ideas can be presented most appropriately in letter form. As you will know, he has shifted to a new road with his new convictions before he would have reached the goal on the worse one (trans. Pfau, 132-133/HSA 6: 219-220).

We can see that Hölderlin's concept of aesthetic sense is more than likely responsible for the discussion of Greek tragedy in the final epistle of the Letters. And, while Schelling rejects Greek tragedy as a model of practical action, he returns to the idea of an aesthetic for philosophy in the "Survey."

There Schelling makes a suggestion that the entirety of philosophical inquiry "belongs properly to aesthetics...For this science [aesthetics] opens access to all of philosophy, because it is only by means of [aesthetics] that we can explain what the philosophical spirit [philosophischer Geist] is. (Schelling adds to the first addition: To philosophize without it is no better than to exist outside of time or to write poetry without imagination)" (103/1: 402, the Historisch-Kritische Ausgabe dates composition of this section in Summer 1797). Through an aesthetic sense (although he does not use the term), one has access to the spirit of philosophy beyond the letter.

Yet how to interpret the role of the aesthetic? Schelling could, for instance, be making an observation like Fichte that a philosopher needs a sense of genius like a poet; just as the "latter needs a sense of beauty; the former needs a sense of truth." 41 An aesthetic sense

\footnotetext{
${ }^{41}$ See "Concerning the Concept of the Wissenschaftslehre" in Early Philosophical Writings. Ed. Daniel Breazeale (Ithaca: Cornell University Press, 1988), 128/1: 74.
} 
would explain how one could follow the spirit of philosophy in contrast to the letter, which is what both Fichte and Schelling claim inspires their readings of Kant.

Schelling's other reference to aesthetics in the early part of the "Survey" concerns the problem of presenting ideas in philosophy. He states that it is only through inconsistent or contradictory expressions that the philosopher can present an idea. It takes an aesthetic sense to grasp the idea within a contradictory expression; "unaesthetic minds" are not adequate to the Idea: "Plato exhausts himself trying to express that the ideas contain a Being that reaches far beyond all empirical existence. Nevertheless, even in our days we encounter "proofs" that show how Plato's ideas are real substances no less than Kant's things in themselves" $(106 / 1: 406)^{42}$

These references are not quite the aesthetic sense that proceeds without "our practical reason having to come to our aid" as Hölderlin states it. But Schelling does proceed to introduce a philosophy of art to overcome the challenge that Hölderlin saw in the search for a principle "capable of dispelling the conflict between subject and object, between our self and the world, yes, also between reason and revelation." Schelling's suggestive remarks may

\footnotetext{
${ }^{42}$ This footnote is for those interested in the arcana of commentaries on commentaries; I think after dealing with Schelling's readings of Fichte, Spinoza, Leibniz and Kant that it is wise to divert from the main text issues arising from his analogy between Kant and Plato. The passages immediately before that cited above are discussed in part in section two of the present chapter, but for heuristic purposes I refrained from raising issues of aesthetics until the exposition was complete. The context of this passage shows how Schelling often separates the spirit of Kant from Kantians: the latter take things in themselves as real substances whereas Kant recognized the limits of theoretical philosophy to make room for practical principles (subsequently, Schelling argues, supplied by Fichte). But what does this say about the analogy between Kant and Plato? Manfred Baum shows how this analogy can be traced to Schelling's reading of the Timaeus, in which he attempts to read critical philosophy into Plato, a reading which had precedent in the work of W.G. Tennemann, who had published in Paulus's journal Memorabilien (which published Schelling's pre-Fichtean essay Über Mythen). See Baum, "The Beginnings of Schelling's Philosophy of Nature," especially 203-208. I mention these details because Baum notes that the analogy suggests paradoxically that the supersensible ground of experience is a thing, but he doesn't indicate who thinks this is the case: Schelling? Kant? Plato? If I am correct, only Schelling's Kantian rivals would interpret this suggestion literally, but Schelling- and according to our young scholar, a consistent Immanuel Kant (and even Plato?)- would argue the opposite: the supersensible ground could only be the practical self.
} 
anticipate a passage in the final installment of the "Survey" near the conclusion, where he writes:

for us all becomes history that we cannot determine a priori. Thus it also does not depend on whether something has a mechanistic determination or occurs according to determinate laws, but on whether we observe this mechanism, and can state its laws. Accordingly, for example, the poet can intentionally make into history what is not history, a necessary event that he exhibits as contingency (not related to general natural mechanism). Thus one permits the historical writer (who is more and more also a poet [Dichter]) a kind of superstition; then where he understands his art he will not take lightly a natural event in history, without thereby suggesting more than bare nature (a higher but also secret hand). - In all the sciences, history preceded theory. So Greek mythology was (wherever its birthplace may be) originally nothing other than a historical schema of nature (that one had not yet begun to explain). So every doctrine of the things of a supersensuous world turns into history (because we do not have any natural laws for this world); and every religion that is theoretical crosses over into mythology, and will and should always be mythology and never something else (because it can really only have poetic truth, and only as mythology is it true) $(1: 472)$.

Let us begin with the context of this passage. The importance of a history a posteriori is that it affirms the causality of freedom within human history. A history a priori would, like the dogmatist, posit the absolute as realized outside of us resulting, philosophically speaking, in fatalism (as Schelling already mentioned in the Letters), and aesthetically speaking, in a state as boring as "the performance of a play in which only perfected beings appear, or reading a novel- such as [Samuel] Richardon's- where ideal people [IdealMenchen] appear, or a Christian epic in which angels- really the most boring of all beings- play the leading roles" (1: 473). ${ }^{43}$ By contrast, a history a posteriori includes human freedom within history, and allows for an infinite striving. We might say that this anticipates Schelling's remarks on revelation in the System of Transcendental Idealism.

\footnotetext{
${ }^{43}$ While working on this passage a friend and I laughed out loud on reading Schelling's polemical digs at both Richardson and angels. Later, in the Philosophy of Art, Schelling states that "In the novels Pamela and Grandison, Richardson is little more than a moralistic writer. In Clarissa he displays a truly objective gift for portrayal, though entangled in pedantry and diffuseness" $(P A, 237 / 5 ; 683)$.
} 
What is also interesting about this passage is the emphasis on history as the basis for philosophical discussions on the objects of the supersensuous world (such as found in Kant: freedom, God and the immortality of the soul) and the relationship between the theoretical content of religion and mythology. We will confine our remarks to mythology. Although brief, Schelling's remarks anticipate his position in the System of Transcendental Idealism, where the truth of philosophy is manifested for all in poetry and mythology. If so, the importance of mythology in the "Survey" derives from the same idea that all people will have access to the truth of religion through its mythico-political content. The difference in comparison to the System of Transcendental Idealism is that Schelling there proposes a specifically philosophical mythology, oriented around the philosophy of art.

Yet this idea of a philosophical mythology may have an antecedent in the "System Program":

The philosopher must possess as much aesthetic force as the poet. Those human beings who are devoid of aesthetic sense [ästhetischen Sinn] are our pedantic philosophers. The philosophy of spirit is an aesthetic philosophy. ${ }^{44}$

Such aesthetic force is granted by beauty, in the Platonic sense, which no matter the author reveals the influence of Schiller via Hölderlin. ${ }^{45}$ Beauty is the goal of an ethic of aesthetic sense, which unites all the ideas; it addresses the entirety of a human being, who often, as Schiller pointed out, is only considered as a fragment of one's whole self. ${ }^{46}$ From this point, the manuscript sets out a program that is very close to the closing pages of the System of Transcendental Idealism: the aesthetic sense of philosophy, properly realized, returns poesy

\footnotetext{
${ }^{44}$ Krell, 24/Jamme-Schneider, 12.

${ }^{45}$ Jean-François Marquet discusses the relationships between Schiller, Schelling and the "System-program" in Liberté et existence. Second Edition (Paris: Les Éditions du Cerf, 2006), 77-80. Note also the suggestion, in distinction to Manfred Frank, that Schelling might have influenced Hölderlin at p. 73.

${ }^{46}$ Friedrich Schiller, On the Aesthetic Education of Man. Trans. Elizabeth M. Wilkinson and L.A. Willoughby (Oxford: Oxford University Press, 1982), 31-43 (The Sixth Letter).
} 
[Poësie] to a higher dignity and a utopian function dissolving the conflict inherent in history and philosophy. Only the art of poetry [Dichtkunst] will remain. ${ }^{47}$

This occurs precisely because poetry will open onto a new mythology, a "mythology of reason," which will serve, for the philosopher, the ideological function of transmitting philosophical ideas to the masses (although, in comparison to later presentations of the new mythology, in a revolutionary and utopian manner): it renders the ideas aesthetic for the use of the people [Volk]:

Thus the enlightened and unenlightened must at long last clasp hands; mythology must become philosophical, and the people rational, while philosophy must become mythological, in order to make philosophers sensuous. Then eternal unity will prevail among us. ${ }^{48}$

This initial reference to a new mythology is the first appearance of one of the Three Conditions that we set out in the Introduction ${ }^{49}$, although as we will see, despite differences in terminology, the latter half of the "System Program" suggests many of developments found in the philosophy of art as found in Schelling's System of Transcendental Idealism, which also concludes with the call to a new mythology that can reconcile the fractured state of humanity (We will also return to the political aspect of new mythology in Chapter 5.4). The "System Program" does possess an important aspect that is lacking from the later system: only here does Schelling- if Schelling's authorship or influence is accepted- speak of the new mythology in egalitarian terms: it is precisely the utopian function of mythology that opens the possibility for an egalitarian society.

\footnotetext{
${ }^{47}$ Krell, 25/Jamme-Schneider, 13.

${ }^{48}$ Krell, 25-26/Jamme-Schneider, 13-14.

${ }^{49} \mathrm{C} 3$ : Artistic production has a socio-political task: it aims to overcome the fragmentary condition of modernity through a new mythology and artistic renewal.
} 
Whoever the author, these passages suggest the strong influence of both Hölderlin and Schelling, and that the "System Program" was an act of sym-philosophy between Schelling and Hölderlin or/with Hegel. Of course, it is difficult to reconcile this with the proprietary remark that "I shall speak here of an idea [namely, the 'new mythology'] that, as far as I know, no human mind has ever entertained. ${ }^{50}$ Who would relinquish his discovery of the idea of the new mythology to Schelling without comment, if it weren't from Schelling himself?

One more comment: the striking invocation of the "Monotheism of reason and of the heart, polytheism of the imagination and art ${ }^{\text {"51 }}$ is, according to Tilliette, unique to the "System-program," and as he puts it, "falls out of the clouds. ${ }^{52}$ However, it might point both forward and backward in Schelling's development. In the Letters we have already seen the 'monotheism of reason' when Schelling rejects Greek tragedy as a model of action in favor of the ideas of reason, demanding that the affirmation of freedom not be compromised. But the "polytheism of the imagination and art" appears under the sublime power of Greek tragedy, even if it is rejected by Schelling. Although imagination [Einbildungskraft] is not mentioned in the final letter, let us recall that for Kant, in the Critique of the Power of Judgment, the sublime arises from the imagination. The dynamical sublime arises from the "all-powerfulness of nature," but only because at the same time, we recognize our independence and superiority over nature. ${ }^{53}$ Schelling appropriates Kant's remarks in his discussion of tragedy, although he, unlike Kant, holds that art can produce a feeling of the sublime. Schelling elides Kant's distinctions by identifying nature, fate and necessity in

\footnotetext{
${ }^{50}$ Krell, 25/Jamme-Schneider, 13.

${ }^{51}$ Krell, 25/Jamme-Schneider, 13.

${ }^{52}$ Tilliette, "Schelling als Verfasser des Systemprogramms?", 45.

${ }^{53}$ Kant, Critique of the Power of Judgment, 145/5: 261-262.
} 
distinction to human freedom. Greek tragedy is all the more terrible when its heroes succumb to fate. This power of tragedy is sublime because it requires us to think that in freedom one only realizes fate (and that not even the gods can elude fate). As we have seen, Schelling struggles with tragedy before rejecting it in favor of the ideas of reason, yet now, the author of the "System Program" attempts to reconcile philosophy and the power of art and imagination.

Then, in the System of Transcendental Idealism, imagination and aesthetic intuition play a central role in the system and in grounding the self's activity. Aesthetic intuition is the activity that drives artistic production, which, because it produces the work of art, reconciles the opposition between freedom and necessity, and opens the possibility for a future mythology. This insight, it seems, had its origins in the discussions between Hölderlin and Schelling sometime between 1795 and 1796, and appeared systematically expressed in the System of Transcendental Idealism, which is the concern of the next chapter. 


\section{Chapter 3}

\section{Artistic Activity and the Subversion of Transcendental Idealism}

\subsection{The System of Subversion}

In the previous two chapters we have followed the development and expansion of Schelling's conception of transcendental idealism. We began with the Letters, which defended critical philosophy from the fatalistic dangers of dogmatism, and then we turned to the early presentations of nature-philosophy, in which Schelling adapted the concept of organic totality, from Kant's concept of teleology and Spinoza's doctrine of the attributes, to his transcendental deduction of a freely-acting, embodied, human being within nature.

At the same time, we have traced the role of art in these developments. In the Letters, Schelling gives great praise to Greek tragedy, which portrays the catastrophe of fate as the ultimate testament to human freedom. But within the problematic of the Letters, Schelling rejects this nascent 'philosophy of tragedy' as a model of human freedom because the ideas of reason prohibit any diminution of the role of freedom; such a diminution risks the moral extinction of the self that plagues dogmatism. Put succinctly: in blaming fate, the self acts in bad faith, and therefore a tragic ethos is only possible for a race of titans (See Chapter 1.5). Human beings cannot embody the absolute identity of freedom and necessity that governs the interplay of freedom and fate. 
Yet Schelling does not abandon the standpoint that philosophy can explain the identity of freedom and necessity, and of subject and object. After the Letters, Schelling began seriously studying the scientific transformations of his time, which he incorporated into his nature-philosophy. The texts of 1797 , the "Survey" and the Ideas, continue to argue for the superiority of criticism over dogmatism by showing how mechanism fails to explain either organic nature or nature as a totality or universe. At the same time, Schelling attempts to show how human freedom can be explained by a combination of practical philosophy and the concept of the organic; in short, he attempts to show how an embodied human being freely acts within nature.

While in most of the "Survey" and the Ideas, Schelling seems satisfied with the primacy of the practical as the ground of philosophy, the final installment of the "Survey," published in 1798 , introduces a tripartite division of the system between transcendental philosophy, nature-philosophy and a philosophy of art, the latter of which, he claims, unites the previous two. It is around this time that, whether or not Schelling was its author, the "System-Program" was written or circulated. This fragment closes by suggesting that the goal of philosophy is a mythology which can unite humanity under free activity through a "mythology in service to ideas...a mythology of reason."

These suggestions are then systematically, and publicly, developed in the System of Transcendental Idealism, and in part, in the First Outline of a System of the Philosophy of Nature. ${ }^{1}$ Thus far we have dealt with the 'prehistory' of the philosophy of art, but in the ST it becomes the "keystone" of the entire system. The task of this chapter will be to address these central questions: how does the philosophy of art overcome the contradiction between freedom and necessity, between the separation of subject and object? And, if the philosophy

\footnotetext{
${ }^{1}$ Henceforth respectively abbreviated as $S T$ and First Outline.
} 
of art overcomes this contradiction, to present the identity of subject and object, why does practical philosophy no longer suffice?

As we will see, the philosophy of art becomes the "universal organ of philosophy" (as the title of Part VI of the $S T$ announces) because it demonstrates the absolute identity of freedom and necessity, of subject and object. Schelling attempts a transcendental deduction of the various stages of self-consciousness, ending in the resolution of the contradiction between free action and necessity in artistic production, and thus unites the division between the two sides of the system: transcendental idealism (which proceeds from the self) and nature-philosophy (which proceeds from the object). Both sides, in themselves, cannot bring self-consciousness to its highest stage.

On the one hand, transcendental idealism leads consciousness in stages to practical reason, in which Schelling argues (like Fichte before him) that free action infinitely strives to approximate its ideals, although it cannot objectively realize them. On the other hand, in organic nature, we can detect purposiveness in its objects, although not in natural processes. In Schelling's terms, while nature shows the identity between conscious and unconscious activity in its products, it does not raise itself to consciousness; more specifically, nature does not represent this identity in the self itself, only lawfulness and purpose in natural objects (ST, 225/3: 620 and First Outline, 193-194/3: 271-272).

Schelling resolves this problem in the final section of the $S T$, when he argues that artistic production- which he also calls aesthetic intuition- demonstrates the identity of conscious and unconscious activity in the self. Although artistic production begins in free activity, it ends in an artwork, which comes about through the work of genius, a Kantian synthesis of freedom and nature. Aesthetic intuition is, as Schelling states, intellectual 
intuition become objective. As it results in an object, artistic production accomplishes an act beyond the infinite striving of the self in practical, moral action, and insofar as the artwork is objective, it brings the self to consciousness of the identity of freedom and necessity, the identity that grounds the absolute self. This harmony of identity also holds out collective promise in the future: art, through the medium of poetry, will bring about a new mythology, "which shall be the creation, not of some individual author, but of a new race, personifying, as it were, one single poet" $(S T, 233 / 3: 629)$. Not only does artistic production present the unity of conscious and unconscious activity, and freedom and necessity, it also offers the possibility of reconciling the individual and society through the intersubjective production of a new mythology.

We are, however, not just interested in how the philosophy of art answers problem of the separation of freedom and nature (or practical philosophy and nature-philosophy). We must also show why Schelling finds his previous two answers to be less than satisfactory. Unlike earlier presentations of nature philosophy, which attempted to unify it with transcendental idealism, the $S T$ and First Outline formally separate these two 'sciences' according to their respective first principles: transcendental idealism begins with the selfactivity of the subject and nature-philosophy begins with the object to establish a system of Spinozistic realism. Each science progresses from its first principle to its opposite (idealism from subject to object, realism from object to subject) but neither can obtain its opposite, rendering both unable to embody the absolute identity in opposition. Practical philosophy can only realize its imperative objectively as an infinite progress, just as nature shows intelligence operating in the world but cannot obtain to consciousness without human activity and the use of reason. By contrast, Schelling's theory of genius shows the identity of 
freedom and nature through the creation of the artwork. Therefore the artwork reflects the absolute within the finite world.

Of the two major texts under consideration in this chapter, we will give priority to the systematic structure of the $S T$, but we must also discuss the First Outline to show how, at this stage, nature-philosophy still conforms to the concepts of transcendental idealism. Both sciences, as Schelling calls them, arise when the philosopher must explain the identity of subject and object that grounds all knowledge. To explain the identity of subject and object, one must start with either the subjective or objective, and with each respective first principle the philosopher attempts to explain the possibility of knowledge of its opposite, and how they concur in representation. Thus for transcendental idealism, the subject is primary, which gives rise to the problem of how an object can be known, and for nature-philosophy the object is primary, and the question is how the subjective (intelligence) can be added to it ( $S T$, $5-6 / 3: 340-341)$.

The systematic separation of these two sciences recalls Schelling's outline of the confrontation between criticism and dogmatism found in the Letters, although the system of realism is no longer the fatalist system of dogmatism but that of nature-philosophy. The two respective systems that begin with either subject or object are no longer two competing approaches to practical philosophy but two sciences within the framework of transcendental idealism. However, in the $S T$, Schelling has added a third branch to the system to unify them, which is the philosophy of art. It is through aesthetic intuition that the self becomes conscious of the identity of subject and object, therefore demonstrating for the self what was presupposed at the outset. 
The importance of the $S T$, I will argue, is its subversion of Fichte's idealism. When Schelling deduces freedom as a necessary illusion of the self's productive activity, he is clearing the way for a higher activity that can exhibit the absolute identity of self and nature in the real world. In short, Schelling subordinates practical reason to the act of aesthetic intuition and thereby demonstrates that freedom (as thought according to an infinite progress toward the moral law) is not the ultimate ground of subjectivity. Instead, this ground is an ethos of artistic activity, a self-creating act that is 'more free than freedom.' Along the way, Schelling constructs the general scheme of the relationship between theoretical-, practicaland art-philosophy that he will maintain in the absolute idealism of the Philosophy of Art.

This position, maintaining the continuity of Schelling's philosophy of art, puts us at odds with the standard interpretation of Schelling's philosophical development. According to this interpretation, Schelling first glimpsed the idea of absolute idealism with the idea of aesthetic intuition in the $S T$, and having reached the absolute in its final section, he could then surpass the subjective idealism of the $S T$ and its philosophy of art. Although not all the commentators are explicit about the basis on which they reach this conclusion, there is a general argument for this interpretation that I will reconstruct in two parts.

The first step is based on Schelling's own interpretation of the $S T$ found in the lectures given nearly three decades after its publication, and posthumously published as $O n$ the History of Modern Philosophy. This self-interpretation has played an important role in subsequent interpretations of Schelling's $S T$, including those of Dieter Jähnig, Walter Schulz, and Andrew Bowie, amongst others. ${ }^{2}$ According to this interpretation Schelling

\footnotetext{
${ }^{2}$ See Dieter Jahnig, Schelling: Die Kunst in der Philosophie, Vol. 1 (Pfüllingen: Neske, 1969), 133ff and 155ff; Walter Schulz, "Einleitung" in System des transzendentalen Idealismus. Ed. Horst D. Brandt and Peter Müller (Hamburg: Felix Meiner Verlag, 1992), xxv-xxx; and Andrew Bowie, Aesthetics and Subjectivity: From Kant to Nietzsche (Manchester: Manchester University Press, 1990), 84-88. These are several of the most commonly
} 
sought, despite the Ficthean exterior, to provide an account of the history of selfconsciousness wherein the objective I is led by the subjective (or philosophizing I) to recognize both its origins in nature and its ground in freedom, through a kind of anamnesis. The relationship between the subjective I and the objective I, who are two distinct individuals, is compared to

the pupil and the master in the Socratic dialogues. In the objective I more was always posited in a developed way than it itself knew; the activity of the subjective, of the philosophizing I now consisted in helping the objective I itself to knowledge and consciousness of what is posited in it, and of finally bringing it in this way to complete knowledge of itself (HMP, 112-113/10: 98).

As Schulz notes, Schelling's claim to a dialectical method is clearly aimed at showing how Hegel's method derives from that of the $S T .^{3}$ This interpretation reads the $S T$, as Werner Marx calls it (albeit Marx is critical of this position), a Bildungsgeschichte or 'history of cultivation' of the I, wherein the I- with the help of the philosopher, overcomes its natural limitations to grasp the nature of its free activity.

The second step is in the standard interpretation is to apply this Bildungsgeschichte to Schelling's own philosophical development to explain the transition from subjective idealism to absolute idealism. That is, once Schelling grasps the absolute identity in artistic activity, he then takes the next step and posits the absolute beyond the subject in the Darstellung meines Systems der Philosophie (1801), without the subjective or heuristic principles found in the $S T$. This argument also has a basis in Schelling's later interpretation (HMP, 110-113/10: 95-98). This has been implicitly suggested by numerous interpreters, ${ }^{4}$

cited texts on Schelling's philosophy of art. It also factors into Emil L. Fackenheim's essay on the $S T$ in The God Within: Kant, Schelling, and Historicity. Ed. John Burbidge (Toronto: University of Toronto Press, 1996), 60-65.

${ }^{3}$ Schulz, "Einleitung," xxviii.

${ }^{4}$ See, for instance, Joseph P. Lawrence, "Art and Philosophy in Schelling," in The Owl of Minerva 20 (1988), 11; Richard L. Velkley "Realizing Nature in Self: Schelling on Art and Intellectual Intuition in the System of 
although it was brought to explicit formulation by Antoon Braeckman, who argues that absolute idealism rests on "the transposition of the inner structure of the work of art [...] to the inner structure of absolute reason in the Darstellung."

A response to this standard interpretation requires refuting both steps: this chapter will argue against the first step, while Chapter Four will refute the second step by showing the continuity of the philosophy of art between the $S T$ and the lectures collected as the Philosophy of Art (1802-1804) from the period of absolute idealism. In this chapter I will argue, following Werner Marx, that the $S T$ is not a history of the self's cultivation, but rather that the "standpoint of the transcendentally philosophizing ego is the one that performs the reconstruction of reason's original self-constitution by disclosing the conditions for the constitution of self-consciousness" through the "free imitation" $(S T, 48 / 3: 396-397)$ of the self's productivity. ${ }^{6}$ The $S T$ does not present a path of cultivation or anamnesis, but a transcendental reconstruction of the conditions necessary for the self to recognize itself as producing objectively. As Marx notes, if it were a case of cultivation of self-consciousness, each time the self encountered a transcendental illusion (such as, according to Schelling, freedom), this would require surpassing the illusion for a true idea or concept. ${ }^{7}$ Instead the $S T$ shows how these illusions must obtain because of the distinction between intuition and reflection, and that they must be maintained for epistemological purposes (reflection). So, for instance, even though we intuit ourselves as natural, embodied beings, we can only know this qua reflection through the concept of teleology.

Transcendental Idealism," in Figuring the Self. Ed. David E. Klemm and Güter Zoller (Albany: SUNY Press, 1997), 159-160. Velkley attributes the shift to Schelling identifying the contingent status of the appearance of genius.

${ }^{5}$ Antoon Braeckman, "From the Work of Art to Absolute Reason: Schelling's Journey Toward Absolute Idealism," in The Review of Metaphysics 57 (March 2004), 551.

${ }^{6}$ Werner Marx, The Philosophy of F.W.J. Schelling. Trans. Thomas Nenom (Bloomington: Indiana University Press, 1984), 48.

${ }^{7}$ Marx, The Philosophy of F.W.J. Schelling, 49. 
In addition, Schelling's later interpretation overlooks the subversive sting of the $S T$ insofar as it forgets that it is precisely through the limitation of freedom, as an infinite task of approximation, that opens the way to demonstrating that aesthetic intuition produces the absolute as art, in the finite or real world; that artistic activity presents what freedom can only approximate. Schelling does a disservice to his early work when he remembers the apex of the System of Transcendental Idealism as "pure freedom" with no reference to the work of art $(H M P, 112 / 10: 97)$.

We will begin by showing how Schelling reaches the conclusion that the art is the "only true and eternal document of philosophy" (ST, 231/3: 627) The importance, as I have stated, is that the production of the work of art, as an act of genius, brings the identity of subject and object- the absolute- to self-consciousness. If the $S T$ subverts transcendental idealism, it is because Schelling argues that the infinite tasks of practical philosophy or nature-philosophy can only approximate the absolute, and not represent it. Thus Schelling turns their inability to present the absolute into a positive condition of the philosophy of art. Art is the "eternal document" of philosophy because it produces, or makes actual, what philosophy can only intuit in the ideal. As we will see, the $S T$ sets out the features that we have identified, in the Introduction, as the Three Conditions of the philosophy of art. As mentioned before, these conditions are the basis of my determination that Schelling gives a continuous priority to the philosophy of art from $1800-1807$. So in the next two chapters, I will argue that they are also present in Schelling's philosophy, no matter the metaphysical ground of his system. In the next chapter, in particular, I will show that, despite the shift to absolute idealism, the philosophy of art still plays a central role in Schelling's thought. 


\subsection{The Limits of Theory and Practice}

\subsubsection{Theory}

Like the "Survey," the System of Transcendental Idealism attempts to deduce a history of self-consciousness that begins with intellectual intuition and results in the highest form of self-consciousness. While for the earlier text this highest form was the will of the practical self, the $S T$ concludes with what Schelling calls an aesthetic intuition, which intuits the identity of subject and object in artistic production. The task of transcendental philosophy is to follow the activity of the self as it strives to produce this identity objectively. The theoretical section of the $S T$ reconstructs the conditions necessary for the subject to attain self-consciousness, while the practical section focuses on the self's attempt to objectify its ideals in an inter-subjective world.

We will briefly discuss the principles of Schelling's theoretical philosophy before moving on to his practical philosophy. The general task of transcendental inquiry, according to Schelling, is to show how the activity of the self can explain objectivity, and he divides this explanation into three 'epochs': intuition, production, and reflection. The first epoch shows how the intellectual intuition of self-activity grounds all knowledge, while production provides a deduction of how the self's activity grounds the possibility of objects, while the epoch of reflection provides an analysis and deduction of the self's consciousness of the categories and concepts. We will focus only on the first epoch of intuition, wherein Schelling sets out the first principle of transcendental philosophy. The first act of the self is that of intellectual intuition, which posits the identity of subject and object; through this act, the self becomes an object for itself, but it does not yet become self-conscious of this identity. The theoretical section, instead, deduces the necessary conditions of self- 
consciousness from the self's activity, while the act whereby the subject becomes selfconscious is reserved for practical philosophy.

Because Schelling holds that subject and object are mutually exclusive principles, the deductions in the $S T$ are limited by the requirement that all explanations of objectivity must be derived by the self's subjective activity, which Schelling calls productivity. ${ }^{8}$ The concept of productivity, which is ultimately grounded in the productive imagination (Einbildungskraft) allows him to orient transcendental idealism around a continuum of the self's activity, from intellectual intuition to aesthetic intuition. Productivity, then, is supposed to overcome the Kantian separation of the faculties by unifying them under a common concept. ${ }^{9}$ But this leads to what appears to be an extreme version of idealism. Schelling makes claims such as: "nothing external can operate upon the self qua self," or "The self is a completely self-enclosed world, a monad, which cannot issue forth from itself, though nor can anything enter it either, from without. So nothing counter-posited (or objective) would ever come into it, unless this too were posited simultaneously through the original action of self-positing" ( $S T, 36-37 / 3: 380-381)$. Such stringent idealism is, Schelling argues, rectified by his nature-philosophy (of Spinozistic realism), but then it becomes all the more important that his philosophy of art reconcile these two extremes. But it could also be said that the concern of transcendental philosophy is strictly epistemological: then Schelling's position is that all knowledge is the result of the self's activity, and that all intuition requires such activity to become objective. Yet if intellectual intuition inaugurates this process of self positing, and objectivity is the result of the self's activity, Schelling must

\footnotetext{
${ }^{8}$ Like many of the terms Schelling chooses, production has both an ideal and a real definition: the ideal production of objectivity finds its limit in the self's productive capacities in the objective (real) world. ${ }^{9}$ For the relationship between Kant and Schelling, see Orrin F. Summerell, "The Theory of the Imagination in Schelling's Philosophy of Identity" in Idealistic Studies, Vol. 34, no. 2 (2004), 85-98; and John Llewelyn, The HypoCritical Imagination: Between Kant and Levinas (London: Routledge, 2000), 50-68.
} 
explain why objects seem necessarily external. Which he does by arguing that the feeling of necessity is a result of these processes remaining unconscious; they never obtain consciousness.

The use of the term 'unconscious' (Bewußtlos), for many readers, suggests a connection to Freud. ${ }^{10}$ This is not entirely unreasonable, although the connection is fairly distant. Dale E. Snow suggests that the introduction of the unconscious implies Schelling's recognition of an irrational element in existence and even within the system. ${ }^{11}$ However, this understates the fact, as Werner Marx argues, that the deductions of the theoretical part of the system concern the self as governed by natural laws; that is, the philosopher follows how the self's (=the intelligence) activity becomes objective ("the unconscious lawfulness of intelligence in its process of becoming conscious." ${ }^{.2}$ ). As I will argue, Schelling holds that nature exhibits a rational structure, with human activity at its apex. In any case, there is, I think, a degree of equivocation in the $S T$ regarding the unconscious, because the section on art implies a kind of agency of nature as compulsion in the artist's activity (referred to as the "unfathomable depth" granted the artist by nature- see $S T, 224 / 3: 619$ ), which is not the same kind of 'unconscious' as developed in either theoretical philosophy or nature philosophy, probably because the philosophy of art has a broader reach than the epistemological concerns of the earlier sections of the book.

The theoretical section of the $S T$ reconstructs what he calls the "transcendental past" of the self. Schelling writes:

\footnotetext{
${ }^{10}$ See, for instance, Odo Marquard, "Several Connections between Aesthetics and Therapeutics in NineteenthCentury Philosophy," in The New Schelling. Ed. Judith Norman and Alistair Welchman (New York: Continuum, 2004), 13-29.

${ }^{11}$ Dale E. Snow, Schelling and the End of Idealism (Albany: SUNY Press, 1996), 125-128.

${ }^{12}$ Werner Marx, The Philosophy of F.W.J. Schelling, 37.
} 
the act whereby the self is objectively limited is a different act from that whereby it is limited for itself... The reason why the self finds itself limited in this action cannot lie in the present action, but rather in one that is past. So the self in its present action is limited without its consent, but that it finds itself so limited is also the whole of what is contained in sensation, and is the condition of all objectivity in knowledge. So in order that the limitation shall appear to us as a thing independent of ourselves, provision is made for this purpose, through the mechanism of sensation, that the act whereby all limitation is posited, as the condition of all consciousness, does not itself come to consciousness ( $S T, 58 / 3: 409)$.

Intellectual intuition posits the self as the identity of subject and object in the self, thereby limiting itself. But as Schelling indicates, this limitation is not yet objective, only in practical philosophy does the self find its power of production limited by the objective world. However, the ideal limitation of intuition never comes to consciousness, so that the self feels itself constrained by an unrecoverable past outside of time (according to Schelling the self's activity does not occur in time, but is the ground of time [ST 38/3: 396]). The result: the conditions of practical action, deduced in theoretical philosophy, are unconscious, which also constitutes the limit of theory. These restrictions limit the self, but can be illuminated by the transcendental philosopher. While theoretical philosophy can deduce these conditions from the first principle of the self's activity, it cannot bring the identity of subject and object to self-consciousness.

\subsubsection{Practice}

In his practical philosophy, Schelling shows how the self comes to consciousness of itself as really productive within a world, and yet he also argues- in a move that subverts the primacy of the practical reason found in Fichte- that this practical activity does not obtain the absolute identity of subject and object. At its basis practical activity divides the identity of subject and object that grounds the self's productive activity, but this separation has some 
important positive consequences for the system: practical activity also becomes the basis for consciousness, individuality, empirical time and the separation of the in itself from appearances in representation. And in more Romantic terms this separation results in the divided nature of the self: "Man is forever a broken fragment, for either his action is necessary, and then not free, or free, and then not necessary and according to law" ( $S T$, 216/3: 608). Practical activity can only approach the identity of freedom and necessity through infinite progress toward the ideal (the categorical imperative) but can never objectively realize this identity (thus the actions appear as either free or necessary). However, as Schelling argues, along the way, the self changes the world by making its activity objective.

Schelling's account of the ground of practical reason underlines two of its important aspects: one, focused on the intersubjective basis of practice, introduces a second free act of the self as ground, and the other, in discussing the role of the imagination, stresses the continuity of the self's productive activity, connecting it to both theoretical philosophy, and later, aesthetic intuition. Practical philosophy begins with a second act of the self. Like the initial act of intellectual intuition, it must be an act of freedom, but unlike intellectual intuition, it is the beginning of consciousness, individuality and empirical time. Schelling argues that the first act of self-consciousness takes place within an intersubjective world, and that it constitutes the origin of the real limitations of the self.

His argument encounters several problems in this regard, which he only superficially confronts; despite his previous insistence that all activity of the self must have its origin within the self, the original act of practical philosophy, which is an act of willing, is "indirectly grounded" by the activity of other selves. It's not that Schelling introduces inter- 
subjectivity that is problematic- which is already anticipated by some brief comments in Fichte's Science of Knowledge- but that Schelling's presuppositions require that all activity and objectivity arise from the self. By contrast, recall that Fichte's 'not-I,' for all its ambiguity, could still be interpreted as qualitatively different from the self, a negation of the self's sphere, and even as another subject: "the not-self [is] simply the counterpart of the self and nothing more. No Thou, no I: no I, no Thou."13 However, for Schelling, the structure of the system will not allow for an external object to cause the self's activity, because the Object is the first principle of the other side of the total system, nature-philosophy.

Hence, in the argument concerning inter-subjectivity Schelling argues that the activity of other intelligences must be recognized as selves and not as objects, which he claims dispenses with the heretofore prohibited influence of externality. This, he states, is possible through a "pre-established harmony" of the universal conditions for the possibility of any self whosoever: "such a harmony is conceivable only between subjects of equal reality, and hence this act must have proceeded from a subject endowed with just the same reality as the intelligence itself" $(S T, 161 / 3: 540) .{ }^{14}$ In any case, this concept of an intersubjective practical world has the advantage of explaining the real limitations of the self's activity by the rightful domain of the free action of other selves, and not by objectivity. Additionally, intersubjectivity constitutes the condition for freedom in both its origins and its

\footnotetext{
${ }^{13} S K, 172-173 / 1: 188-189$.

${ }^{14}$ But Schelling makes sure to distance his philosophically overdetermined use of "pre-established harmony" from Leibniz: "the explanation should not venture to extend further, to some absolute principle, which, by operating as the communal focus of intelligences, or their creator and agent of uniformity (concepts wholly unintelligible to us), should contain the common basis of their agreement in regard to objective presentations" (ST, 164/3: 544).
} 
realization within history as a universal rule of law. ${ }^{15}$ We will return to the historical aspect of practical reason and its relationship to mythology in the final section of this chapter.

While the inter-subjective interaction of other intelligences "elicits" the self's free activity, this does not remove the first practical act from the entire succession of acts leading from intellectual intuition to the self-consciousness of absolute identity. However, Schelling's deductions show how, at its basis, practical action sunders the self's identity. In this regard, Schelling returns to the fundamental problem that we discussed in the Letters: how it is "possible to have a transition from the subjective into the objective" ( $S T, 182 / 3$ : 566) That is, the problem of the relationship between the self's infinite free activity and the finite world.

Schelling's deduction of practical action, again, rests on the postulate that the subjective can never be determined by the objective. As mentioned in the theoretical exposition of the $S T$, objectivity is grounded in the self's productivity, though this productivity is unconscious. Willing, as Schelling defines it, is activity directed towards an external object, and thus cannot be identical to this object. Therefore, at its very basis, freedom cannot realize the identity between practical activity and producing; there must be a difference between the will's activity and the object. Thus practical reason cannot fulfill the demand that philosophy discover the act in which the self becomes conscious of absolute identity, Schelling must still show how practical reason fails to do so.

\footnotetext{
${ }^{15}$ Schelling's argument is heavily influenced by Kant's "Idea for a Universal History from a Cosmopolitan Point of View," in Kant: Selections. Ed. Lewis White Beck (New York: Macmillian, 1988), 415-425/8: 17-31. See W. Marx, The Philosophy of F.W.J. Schelling, 1-32; and Jürgen Habermas, "Dialectical Idealism in the Transition to Materialism: Schelling's Idea of a Contraction of God and its Consequences for the Philosophy of History," in The New Schelling. Ed. Judith Norman and Alistair Welchman (New York: Continuum, 2004), 4347.
} 
In practical action there arises the contradiction between the infinite capacity of the will and the finite "compulsion to represent," or between infinite activity and particular objects ( $S T$ 176ff/3: $558 \mathrm{ff}$ ). This contradiction is resolved, Schelling argues, by the activity of the imagination, which "wavers" between infinity and finitude, and which serves as the connection between theoretical reason (the activity of representation) and freedom (and, as we will see, aesthetic intuition). The products of imagination are Ideas, which have their origin in reason itself, and not the understanding. Moreover, just as Schelling proposes the imagination as the mediator between the will and representation, he proposes the ideal as the mediator between the Idea and the object. The opposition between ideal and object "engenders the drive to transform the object as it is into the object as it ought to be" ( $S T$, 177/3: 559). Because the self is divided between the unconscious producing of representation and conscious willing, the demand to realize the ideal in the intuited object gives rise to the drive "directly bent upon restoring the lost identity of the self" ( $S T, 177 / 3$ : 560). Yet even if the self can realize the ideal in transforming the object, its attempt to restore the lost identity can only be realized in a progressus ad infinitum; while the ideal can be actualized in the present, the Idea remains infinite.

Yet this infinite progress leaves 'man a broken fragment' because of the difference between the intuiting self (as productive) and the practical self (as willing). As Schelling argues, in practical philosophy the distinction between the in-itself and appearances obtains. Because Schelling begins with the presupposition that the entire transcendental system rests on the self's activity (including both representation and freedom), he reaches the conclusion that free action is only an appearance to the self; or, in word, an illusion. This illusion is a consequence of the difference between the intuiting self, which is both ideal-real, and the 
practical self, which acts ideally. ${ }^{16}$ In itself, the self is both intuitant and activity; both the external object and freedom are grounded in the self's activity. However, all practical action is that of modifying the intuiting self's production of objects. Because the self's production is unconscious, it appears to be grounded in external objects.

The problem is that for ordinary consciousness the self acts freely in a world of natural objects, while according to the transcendental standpoint, the self "can never be anything other than it is, namely subject and object at once, that is, productive" (ST, 184/3: 569), though blindly productive. Although the identity of subject and object as the basis of production is not a problem for theoretical philosophy, where this identity obtains but is unconscious, it is a problem for practical philosophy. Between the two, we are presented with the contradiction between the self's activity as free, or as necessary, but in-itself, the self is both productive and free.

Like Fichte before him, Schelling holds this transcendental illusion necessary, because the reality of representation is grounded in the self's practical activity; only insofar as the self acts does its representations becomes objectively real. "If the objective world is a mere appearance, so too is the objective element in our acting, and conversely, only if the world has reality, does the objective element in action also possess reality" ( $S T, 185 / 3: 570)$. Free action is, at its basis, an intuition, but it does not appear as such because free activity is confined to the laws of intuition, to natural laws. But as stated at the outset, this identity will not obtain for self-consciousness; it "cannot be evidenced in free action itself, since precisely for the sake of free action...it abolishes itself' $(S T, 213 / 3: 605)$. Thus we see that practical action cannot bring the identity of subject and object to self-consciousness. Qua action

\footnotetext{
${ }^{16}$ This conclusion supports my argument, following Werner Marx, that the transcendental method of the $S T$ is incompatible with Schelling's later claim that it supplies a Bildungsgeschichte. See Section 3.1.
} 
freedom appears, but in-itself, such action stands under the necessity of natural laws. And as previously mentioned, the task of transcendental idealism is to explain how absolute identity obtains self-consciousness. This will require a third branch of philosophy to resolve this central problem, the solution of which is reserved for the philosophy of art. But before considering the philosophy of art, Schelling proposes an examination of teleology and nature. He will argue that nature-philosophy can show how organisms are productive but without intention. While this provides an account of nature that is productive and not merely mechanistic, Schelling will also argue that nature-philosophy also requires the philosophy of art to show how the identity of freedom and necessity is made conscious.

\subsection{Teleology and Nature-philosophy}

The discussion of teleology is not the only time that Schelling considers the relationship between nature and the self in the System of Transcendental Idealism. Though these passages are arguably the strangest parts of the $S T$, in the epochs of theoretical philosophy, Schelling deduces- in the first- matter and the dynamic processes (such as chemistry, electricity and galvanism), and-in the second-the self-production of living organization. As discussed in Chapter 2, organization furnishes Schelling's arguments for the embodiment of the self. For instance, Schelling notes that "insofar as the intelligence produces unconsciously, its organism is immediately identical with it, in such a way that what it intuits externally is reflected by the organism without further mediation" (ST, 129/3: 499). However, confined to the theoretical section, this natural aspect of the self remains unconscious. Hence, because practical action sunders this identity, the system requires a 
theory of teleology in order to secure the epistemological status of organic nature for the self.

The principles of teleology demand that nature be investigated by the self as appearing as purposive, but not purposive in its production. This position is similar to the Ideas (which appropriated Kant's concept of teleology; see Chapter 2.5), but now Schelling does hold that mechanism and organic nature are incompatible. Thus organic nature- in either the particular or nature as totality- must be considered as producing through "blind mechanism." Literally, nature is unconscious. So while nature appears as both the product of conscious forces (the concept) and unconscious forces, the task of transcendental idealism is to explain how the self grasps this identity for itself. Teleology exhibits the identity of subject and object, but only in the object, and not the self. In addition, Schelling gives this problem a twist: it is only possible for the self to grasp the teleological character of nature if it has already intuited the identity of subject and object. This is only possible through aesthetic intuition.

Yet, while the principles of teleology are limited within transcendental idealism, they are not exhaustive of nature philosophy. By the time the $S T$ had been published, Schelling had already published the First Outline of a System of the Philosophy of Nature (1799) and its separate Introduction, the latter of which sets out the formal principles of a realist "speculative physics," or, "Spinozism of physics," subordinated to the task of explaining the ideal (subject) through the real (object) (First Outline, 194/3: 273). Although, as we have seen, the $S T$ prohibits all acts of the self from being explained by objective causes, in the Introduction Schelling suggests that reason could be a "mere play of higher and necessarily unknown natural forces (First Outline, 195/3: 273-274). This claim is not meant to reduce 
humanity to the "most unfortunate, most delicate, most evanescent beings" as Nietzsche would have it, but to demonstrate how reason itself is a law giving force for nature itself, which leads to the highest potency of nature's productivity: self-consciousness. ${ }^{17}$ For Schelling, the highest determines the lower; the most perfect provides the rule in human activity and in nature. This suggests that an aesthetic intuition underlies nature-philosophy.

Despite Schelling's claims to the contrary, nature-philosophy, like the $S T$, is riddled with inconsistencies. While Schelling makes claims to demonstrating a system of speculative physics (which is realist), nature-philosophy maintains a transcendental framework, and is thus also grounded in the principles of transcendental idealism, which concludes with a philosophy of art. In fact, nature-philosophy contains many formal structures which are isomorphic with transcendental idealism. In the $S T$, Schelling himself draws the parallel: "Precisely as the intelligence, by means of succession, constantly tries to depict the absolute synthesis, so likewise will organic nature constantly appear as struggling towards universal organism and at war against an inorganic nature" (ST, 125/3: 494). Nature-philosophy begins with an original identity between productivity and product, which is sundered in order to make empirical nature possible, just as the identity of the self is split in transcendental idealism in order to explain the possibility of the objective. And on both sides of the system, the agency of productivity posited as the ground of the system strives to return to the lost identity.

For the first principle, Schelling posits nature as productive and not just a totality of empirical objects. But nature is not just assumed, as in the teleological investigations of the

\footnotetext{
${ }^{17}$ Friedrich Nietzsche, "On Truth and Lie in an Extra-Moral Sense," in The Portable Nietzsche. Ed. Walter Kaufmann (New York: Penguin Books, 1954), 43.
} 
$S T$, to appear as a totality; instead, Schelling argues that nature is an organic, productive totality. Literally, nature-philosophy is a Spinozist physics:

Insofar as we regard the totality of objects not merely as product, but at the same time necessarily as productive, it becomes Nature for us, and this identity of the product and productivity, and this alone, is implied by the idea of Nature, even in the ordinary use of language. Nature as mere product (natura naturata) we call Nature as object (with this alone all empiricism deals). Nature as productivity (natura naturans) we call Nature as subject (with this alone all theory deals) (First Outline, 202/3: 284).

Again, Schelling's appropriation of the concepts of natura naturata and natura naturans betrays a desire to reconcile both, philosophically speaking, the thought of Spinoza with Fichte, and 'existentially'- to use an anachronistic term- human being and nature. This attempt at reconciliation is one of the factors restricting nature-philosophy to a transcendental framework, which here involves resolving the contradiction between nature as productivity and nature as product. His solution, like that of practical philosophy, will be that nature is possible only insofar as it infinitely approaches the identity of absolute productivity or absolute product: nature cannot be absolute productivity or else there would be no products, and conversely, it cannot be absolute product because this would extinguish all productivity. Thus, while at its very basis, nature is "originally only productivity" (First Outline, 202/3: 284), it must be thought as the duplicity of productivity and product (limitation). According to Schelling, nature must, like the self, become and object to itself: "Nature must originally be an object to itself; this change of the pure subject into and object to itself is unthinkable without an original diremption in Nature itself' (First Outline, 205/3: 288). Therefore, nature is at the same time productive and limited, infinite and finite. Yet it is precisely around the question of explaining the limitation of nature's productivity that the Introduction perpetually circles. There are explanations and deductions involving the mathematical continuum, galvanism and the metaphor of a whirlpool, the latter of which is 
particularly à propos of Schelling's conceptual struggle- continuing through the period of identity-philosophy- with the transition from absolute productivity (infinite nature) and limitation (determinate products):

Suppose, for illustration, a stream; it is pure identity; where it meets resistance, a whirlpool is formed; this whirlpool is not an abiding thing, but something that vanishes at every moment, and every moment springs up anew. -Originally, in Nature there is nothing distinguishable; all products are, so to speak, still in solution, and invisible in the universal productivity. It is only when retarding points are given that they are thrown off and advance out of the universal identity. - At every such point the stream breaks (the productivity is annihilated), but at every step there comes a new wave which fills up the sphere (First Outline, 206/3: 289).

As with the image of the whirlpool, Schelling proposes various kinds of limitations through dynamic processes but does not deduce the principle of limitation itself until he shifts, in the concluding pages of the Introduction to a more aphoristic and axiomatic style. Transcendental methods of inquiry into nature such as found in the Ideas are abandoned for the elucidation of the axioms of his speculative physics. Yet, strikingly, the explanation follows the same structure as that of practical action: specifically, nature is a striving, out of duplicity, for the identity of productivity and product. But if this identity is actualized in nature as totality, all difference collapses, it falls into indifference (Indifferenz), a concept central to his later philosophy of identity, which is the focus of the next chapter. Individual natural objects, obtain as relative points of indifference but they are only possible insofar as nature in toto infinitely strives towards the absolute point of indifference (First Outline, 224/3:315).

Although Schelling's inquiry formally abandons the method of transcendental idealism because of his use of axioms (recalling Spinoza), nature-philosophy remains 
grounded in the activity of the self. ${ }^{18}$ Despite the introduction of terms such as 'Indifferenz' and the first appearances of the Schelling's uses of the concepts of the potencies ${ }^{19}$ (which we will discuss in Chapter 4), the system has not yet arrived at absolute idealism. As JeanFrançois Marquet emphasizes, the opposition between productivity and product is based in the opposition in the self between intuition and reflection. The absolute continuity of productivity "exists only for intuition" while "all the laws of mechanics, whereby that which is properly only the object of the productive intuition becomes an object of reflection, are really only laws for reflection" (First Outline, 203/3: 285-286). This last claim, we can add, holds for Schelling's criticisms toward the capacity of reflection to explain the productivity of the self. The upshot, however, is that nature as productivity (natura naturans) can also be grasped by intellectual intuition, as Schelling claimed in the introduction to the $S T$. However, absolute identity, sought in the early pages of the $S T$, is only proved indirectly in nature, while, as he notes, for both self-consciousness and philosophy, it "is directly proved in the case of an activity at once clearly conscious and unconscious, which manifests itself in the productions of genius" (First Outline, 193/3: 271).

\subsection{From the "Phenomenology of Genius" to the New Mythology}

So far we have focused on the limits of theory and practice. The remainder of this chapter will be dedicated to showing how Schelling's philosophy of art undertakes a "phenomenology of genius"20 to demonstrate that the activity of artistic production

\footnotetext{
${ }^{18} \mathrm{My}$ argument is indebted to Jean-François Marquet, Liberté et existence. Second Edition (Paris: Les Éditions du Cerf, 2006), 173-174.

${ }^{19}$ Marquet, Liberté et existence, 170-171.

${ }^{20}$ The phrase is Jean-François Marquet's. See "Schelling et le destin de l'art," in Actualité de Schelling. Ed. G. Planty-Bonjour (Paris: Vrin, 1979), 77. This phenomenology attempts to explain the activity of genius through a transcendental framework, but what is interesting is that these discussions often lack reference to the self
} 
overcomes the separation of freedom and necessity. Then we will conclude with a commentary on the political role played by the promise, found in the "System Program" and the System of Transcendental Idealism, of the "mythology of reason."

Schelling's use of the concept of genius to overcome the separation of freedom and nature is not without precedent: the close proximity of art and nature can be found in the central figures of the Sturm und Drang, Romanticism, and even in Kant. ${ }^{21}$ Take, for example, Goethe, who was no small figure in Schelling's life: in a passage from The Sorrows of Young Werther, the protagonist reflects on the relationship between nature and artist and resolves "in future to rely on nature alone" as a basis for art, as "It alone is infinitely rich, and it alone forms the great artist."22 Or, take Kant, who acknowledges genius as "the inborn predisposition of the mind (ingenium) through which nature gives the rule to art."23 Even Fichte, as we noted in Chapter 2.6, hinted at a connection between philosophizing and a kind of genius like that of artists and poets.

A further comparison with Fichte is illustrative. In his System of Ethics, Fichte writes that fine art "makes the transcendental point of view the ordinary point of view" through an aesthetic. $^{24}$ The $S T$ makes similar statements, but there is a crucial difference: Fichte's consideration of aesthetics is didactic because practical reason maintains priority over artistic production. Although the aesthetic point of view regards the relationship of the self's activity

itself, most likely because the genius's self-knowledge is necessarily obscured by the unconscious dimension of production.

${ }^{21}$ For an account of the use of the concept of genius in natural science, see Simon Schaffer, "Genius in Romantic Natural Philosophy," in Romanticism and the Sciences. Ed. Andrew Cunningham and Nicholas Jardine (Cambridge: Cambridge University Press, 1990), 82-98.

${ }^{22}$ The Sorrows of Young Werther. Trans. Burton Pike (New York: The Modern Library, 2005), 16.

${ }^{23}$ Critique of the Power of Judgment. Ed. Paul Guyer (Cambridge: Cambridge University Press, 2000), 186/5: 307).

${ }^{24}$ Fichte, The System of Ethics. Ed. Daniel Breazeale and Günter Zöller (Cambridge: Cambridge University Press, 2005), 334/4: 353-354. He explains that "from the transcendental point of view, the world is something that is made; from the ordinary point of view, it is something that is given; from the aesthetic point of view, the world is given, but only under the aspect of how it was made." 
to the moral law as one of freedom, "our ultimate end, however, is the self-sufficiency of reason." ${ }^{25}$ For Schelling, by contrast, artistic production- what he calls aesthetic intuition- is the real expression of reason; it objectively produces what philosophy can only address ideally with intellectual intuition. Schelling stands out from his predecessors by the conceptual priority given to the activity of genius and artistic production, for it alone (qua praxis) has the capacity to overcome the contradiction between freedom and necessity, and conscious and unconscious activity, and thus overturning the Fichtean priority of practical philosophy. In addition, insofar as artistic production reconciles the central contradiction between freedom and necessity, the accompanying phenomenology provided by Schelling concerns both epistemology and being of the self as a 'whole person.'

Thus Schelling breaks with the Enlightenment tradition by eliminating reference to external standards of art such as taste, morality, or aesthetics (as a science of sensation) Instead, Schelling's focus is the search for the idea produced through art, that is, the truth of art. $^{26}$ This ultimate truth is produced through beauty. The task, for us, remains to show how Schelling's philosophy of art deposes practical philosophy. Or, in Schelling's terms, the task is to show how intellectual intuition becomes objective, which occurs through the activity of genius, through aesthetic intuition. Aesthetic intuition brings the self to consciousness of the absolute identity of subject and object through the production of the artwork. Thus, Schelling undertakes a transcendental inquiry or "phenomenology of genius" to deduce aesthetic

\footnotetext{
${ }^{25}$ Fichte, The System of Ethics, 335/4: 354.

${ }^{26}$ An important exception to the general trends of the Enlightenment in this regard is Hamann, who, in his Christian mysticism and/or metaphysics, held that "poetry is the mother-tongue of the human race." See the Aesthetica in nuce in Writings on Philosophy and Language. Ed. Kenneth Haynes (Cambridge: Cambridge University Press, 2007), 60-95. For an overview of the Enlightenment philosophy and aesthetics, see Ernst Cassirer, The Philosophy of the Enlightenment. Trans. Fritz C.A. Koelln and James P. Pettegrove (Princeton: Princeton University Press, 1951), 275-360; and for a Marxist interpretation see Terry Eagleton, The Ideology of the Aesthetic (Oxford: Blackwell Publishers, 1990), 13-152.
} 
intuition as the ground of the possibility for the artwork, as the presentation of absolute identity through the work of art.

To do so, Schelling deduces the product (the artwork) and then act of production that makes the product possible. The product will unite the conscious activity (like freedom) and the unconscious production of nature. It is the opposition of freedom and necessity that drives this activity, although Schelling gives two different accounts of how the activity begins. On the one hand, he argues that genius sets out from freedom and ends in the necessity of the artwork's inner harmony; genius is an activity "freely granted by [the artist's] own nature" (ST, 223/3: 617). Yet, on the other hand, he also claims that artistic production arises due to inner conflict, and that this "can be justifiably inferred already from the testimony of all artists, that they are involuntarily driven to create their works and that in producing them they merely satisfy an irresistible urge of their own nature" (ST, 222/3: 616). ${ }^{, 27}$ These two accounts seem to beg the question. The difficulty, I think Schelling would argue, is that the philosophical account of artistic production requires dividing and analyzing that which is not separated in activity. Let us recall that Fichte's positing of the absolute I also exhibited circularity, and Schelling, it seems, has displaced this circularity on to the activity of genius, with the difference being that, according to Schelling, that genius produces an objective proof- the artwork- for absolute identity.

Interestingly, the artist-genius revives the figure of the tragic hero discusses in the Letters. Recall that the tragic hero, the "man of destiny," acts freely but is ultimately condemned by fate to be punished for the unforeseen consequences of his actions. Unlike in the Letters, this figure is no longer confined to the past of Greek mythology:

\footnotetext{
${ }^{27}$ This does not mean that artistic production can be accomplished without discipline or training. Schelling stresses that art requires conscious thought and reflection along with the poesie granted by nature (ST, 223-224/ 3: 618-619).
} 
Just as the man of destiny does not execute what he wishes or intends, but rather what he is obliged to execute by an inscrutable fate which governs him, so the artist, however deliberate he may be, seems nonetheless to be governed, in regard to what is truly objective in his creation, by a power which separates from all other men, and compels him to say or depict things which he does not fully understand himself, and whose meaning is infinite $(S T, 223 / 3: 617)$.

Instead of being excluded from a system of freedom, the activity of the artist (who exhibits the same characteristics as the tragic hero) is now the basis of both practical and theoretical philosophy. However, the identity of conscious and unconscious activity is not expressed in the activity but the product: the work of art.

The work of art is the centerpiece- pun intended- of the system, because, as Andrew Bowie points out, for Schelling "we only ever 'see' products, not the productivity."28 The subordination of practical philosophy to the philosophy of art occurs because the infinite striving of practice can never be completely objective, and it itself relies on the separation of subject and object to appear, while aesthetic intuition results in the artwork, presenting [darstellen] the infinite in finite form $(S T, 225 / 3: 620)$. The infinite characteristic of art is based in 1) the lack of rule leading to its creation, meaning that the artwork presents its own rule; and 2) the cessation of striving, resulting in "calm, and silent grandeur." Or, in less technical terms, the artwork exhibits both infinite beauty and harmony. But the artwork is also superior to natural objects because, 1) they only exhibit the appearance of intelligence (whether we are talking about the teleology of the $S T$ or the concept of natura naturans in nature-philosophy), and 2) the art product resolves the central contradiction of the system, overcoming the separation of subject and object in the self's activity. Artistic production confronts a human being not as a fragment, but as a whole. And finally it presents what philosophy can only show in ideal form:

${ }^{28}$ Andrew Bowie, Schelling and Modern European Philosophy (London: Routledge, 1993), 50. 
art is at once the only true and eternal organ and document of philosophy, which ever and again continues to speak to us of what philosophy cannot depict in external form, namely the unconscious element in acting and producing, and its original identity with the conscious (ST, 231/3: 627-628).

Art is paramount in a dual sense for Schelling. First, aesthetic intuition is intellectual intuition become objective: aesthetic intuition removes the objection that the absolute self is a kind of 'subjective deception' by presenting its objective truth in the product of the artwork. Remember that Schelling holds that freedom is a necessary illusion for the self because practical philosophy rests on the separation of subject and object. By contrast, the subjective element of activity is joined with the objective (unconscious) in aesthetic intuition, resulting in the artwork.

It is important to pause on this statement regarding the relationship between philosophy and artistic activity, because some of the secondary literature grants to artistic activity sovereignty or autonomy over philosophy, a sovereignty that is lost in the period of absolute idealism. ${ }^{29}$ To claim that artistic production is sovereign over philosophy severs the unity between intellectual intuition and aesthetic intuition. For Schelling intellectual intuition and aesthetic intuition are unified by the imagination (Einbildungskraft) $(S T, 230 / 3: 626)$; the former is expressed ideally while the latter is expressed in the real, objectively as the work of art. Because art is produced objectively, it leads the self itself "up to the very point where we ourselves were standing when we began to philosophize," verifying the transcendental inquiry $(S T, 232 / 3: 628-629)$.

It is the concept of the imagination that allows Schelling to unify theoretical-, practical-, and art-philosophy (see 3.2.2 above concerning practical philosophy). As I

\footnotetext{
${ }^{29}$ See Frederick C. Beiser, The Romantic Imperative: The Concept of Early German Romanticism (Cambridge, Mass., Harvard: 2002), 73-87; German Idealism: The Struggle Against Subjectivism 1781-1801 (Cambridge, Mass., Harvard: 2002), 584-585. My difference with Beiser rests on the priority I think should be given to Schelling's systematic use of the concept of imagination. We will return to this point in Chapter 4.3, p. 142ff.
} 
mentioned earlier, the imagination is the basis for the continuity of activity in the self's productive activity: in thought, the imagination allows the philosopher to think and combine what is contradictory- for example, the identity of subject and object- and in artistic activity, it produces the inner harmony of the artwork: hence "that which appears to us outside the sphere of consciousness, as real, and that which appears within it, as ideal, or as the world of art, are also products of one and the same activity" (ST, 230-231/3: 626). In philosophy this activity is intellectual intuition; in art, it is aesthetic intuition, the production of beauty. Of course, Schelling refers to artistic production as the highest potency (höchsten Potenz) of the imagination, which seems to contradict my argument against the continuity of Schelling's art-philosophy between the $S T$ and the Philosophy of Art, except that this is exactly what he says in the latter text (which is the focus of Chapter 4). ${ }^{30}$

Second, art plays a significant socio-political role for Schelling. Not only does art close the circle of transcendental philosophy, the philosophy of art opens the possibility of returning philosophy to its origins in poetry and mythology. This mythology will also, as mentioned in the "System-Program," play a utopian role within community: it "shall be the creation, not of some individual author, but of a new race, personifying, as it were, one single poet," which could arise "in the future destinies of the world, and in the course of history to come" (ST, 233/3: 629). Despite these difficulties, art plays an ideological role; it embodies the results of transcendental philosophy and presents these results for all; the philosopher and non-philosopher both recognize the universal character of art. ${ }^{31}$

\footnotetext{
${ }^{30}$ See also Orrin F. Summerell, "The Theory of the Imagination in Schelling's Philosophy of Identity" in Idealistic Studies, Vol. 34, no. 2 (2004), 85-98.

${ }^{31}$ As Eagleton states, "the ordinary subject-in-the-street is not quite up to the mysteries of Schellingian philosophizing, and stands in need of some more sensuously representational embodiment of it if its reconciling power is to be effective." In The Ideology of the Aesthetic, 135.
} 
This role of mythology was anticipated, as we saw, in both the "Survey" and the "System Program" (see Chapter 2.6). Because this account of the $S T$ is close to that of the "System Program" (and because this document's author remains in question) we will focus on the differences with the "Survey" and the problems they present: there mythology appeared within the philosophy of history as the poetic truth of religion. I argued that Schelling's general point concerned the role of revelation, as the role of human freedom in bringing about the absolute as an infinite task. At no point in history is freedom (qua absolute) perfectly realized, or else all free action would be nothing but necessity (1: 473, $S T, 210 / 3:$ 602). In the "Survey," Schelling states that such an absolute state of reason [VernunftZustandes (sic)] would be as boring as watching a play where only "perfected beings appear" (1: 473). ${ }^{32}$ By contrast, Schelling's system argues that an infinitely progressive revelation is revealed through freedom. Schelling returns to the metaphor of theatre:

if the playwright [i.e. God] were to exist independently of his drama, we should be merely the actors who speak the lines he has written. If he does not exist independently of us, but reveals and discloses himself successively only, through the very play of our own freedom, so that without this freedom even he himself would not be, then we are collaborators of the whole and have ourselves invented the particular roles we play $(S T, 210 / 3: 602$.

He provides three progressive stages of revelation: destiny, natural law, and providence (my argument follows $S T, 211-212 / 3: 603-604)$. Schelling's comments aim to reflect what he thinks each era's self-conscious interpretation to be because he argues that from a later era the sense of the preceding era changes, so that which appears as destiny then appears as natural law and then as providence. So, first, the period of destiny is that of blind fate. He calls this era the "tragic age," which is that of antiquity and its glories and downfall, which

\footnotetext{
${ }^{32}$ Recall that, according to Jacobi, Lessing mentioned the utter boredom he felt toward the idea of a personal God.
} 
itself appears as tragic. The second is that of natural law, beginning with the Roman Empire and that, Schelling implies, still holds sway through his era, in which freedom operates under a "mechanical conformity to law." The final stage is providence, which has yet to come. Schelling writes that the "the third period of history will be that wherein the force which appeared in the earlier stages as destiny or nature has evolved itself as providence, and wherein it will become apparent that even what seemed to be simply the work of destiny or nature was already the beginning of a providence imperfectly revealing itself' $(S T, 212 / 3$ : 604). It is with the concept of providence, which is "to come" (to borrow a phrase from Derrida), that Schelling's philosophy of revelation shows its inconsistencies.

A primary inconsistency becomes manifest because the philosophies of history and revelation are contained within the practical philosophy of the $S T$, indicating that the realization of providence has some relationship to the "gradual realization of the rule of law" within a league of nations $(S T, 203 / 3: 593) .{ }^{33}$ However, while this was the outcome of Kant's "Idea for a Universal History from a Cosmopolitan Point of View," Schelling closes the $S T$ with the invocation of a higher revelation, that of poetic mythology. He seems less content than Kant with providence being equated with the realization of a universal rule of law. ${ }^{34}$ Schelling argues that the state functions as a legal mechanism to guarantee the realization of individual freedom, although this mechanism lacks any moral force. Any attempt to realize the state as a moral force, Schelling claims (most likely with the French Revolution in mind), leads to despotism. Thus "although the legal system performs the same

\footnotetext{
${ }^{33}$ As Werner Marx convincingly argues, the relationship between history, revelation and practical philosophy is internally inconsistent. Schelling himself indicates dissatisfaction with the equation of universal rule of law and providence $(S T, 196 / 3: 584)$. We have multiplied the problems by trying to assess the relationship between mythology and revelation, and practical philosophy and the philosophy of art. See Marx, The Philosophy of F.W.J. Schelling, 1-32.

${ }^{34}$ See Kant, "Idea for a Universal History from a Cosmopolitan Point of View," 424/8: 30.
} 
office, materially speaking, that we expect, in fact, from providence, and is altogether the best theodicy that man is able to contrive, it still does not do this in form... with judgment and forethought" (ST, 196/584). This indicates, for Schelling, that the epoch of providence is yet to come, but also suggests that, in overcoming the age of natural right, society must also be transfigured. Yet we are still presented with the problem of the relationship between providence and the new mythology, which Schelling himself leaves unresolved. There are two options. If we decide to abandon the distinction between practical philosophy and the philosophy of art against the letter of Schelling (and we will not), to combine providence and the new mythology, ${ }^{35}$ this risks removing the systematic priority of artistic production, because the philosophy of revelation deduced within practical philosophy could plausibly render the philosophy of art either redundant or superfluous. If, however, we take this separation seriously, as we have, these tasks 'to come'- the universal rule of law, revelation and mythology-are inconsistent.

In any case, in a broader historical and political sense, Schelling's utopian mythology presents an alternative ideal to the developments of capitalism in the $18^{\text {th }}$ century. Schelling specifically contrasts artistic production with economic production, arguing that artistic production presents a sense of dignity and value above and beyond exchange value (what Schelling calls 'the useful'). This contrast allows us to symptomatically read Schelling's concern, shared by his Romantic contemporaries, with the separation of human beings from nature as a crisis engendered by capitalism: the greater the progress of economic development, the more the natural 'quality' of human being recedes. As Karl Marx noted, some of the benefits of capitalist development were the end of traditional feudal relations of domination regulating people's lives, which includes the strictures of morality. The urbane

\footnotetext{
${ }^{35}$ See Alan White, Schelling: An Introduction to the System of Freedom (New Haven: Yale, 1983), 69-70.
} 
German, of course, lived with some of the cosmopolitan benefits of these transformations, including Schelling with his unconventional living situation with Caroline Böhmer Schlegel, the wife of August. But these transformations, as the Romantics recognized, also denigrated the dignity and aesthetic dimensions of nature through its exploitation. In response, Schelling proposed the revival of the mythology, in a philosophical form. Hence the importance of the Greeks, who in the Letters Schelling called more 'natural' than the moderns, and who exhibited (or so the German tradition thought) an organic totality in society. In the $S T$, they are the exemplar of the infinite meaning of art:

the mythology of the Greeks, which undeniably contains an infinite meaning and a symbolism for all ideas, arose among a people, and in a fashion, which both make it impossible to suppose any comprehensive forethought in devising it, or in the harmony whereby everything is united into one great whole $(S T, 225 / 3: 619-620){ }^{36}$

What Schelling did not recognize is that this image of Greek mythology was an ideological projection of German concerns onto the social relations of ancient Greece (which were not 'organic' and autochthonic). The danger of this position lay in the potential of confusing the truth of art, as expressing something fundamental about human activity, and art's ideological function in mythologizing political relationships (the mythologization of these relationships as an organic community has dangerous political connotations when connected to the project of nationalism. We will return to this subject in chapter 5). Nevertheless, the idea of a philosophical religion remains a constant feature within Schelling's thought, and through 1807 , he held that it was the task of an artistic renewal through a new mythology.

\footnotetext{
${ }^{36}$ It is interesting to note that both practical philosophy and even the philosophy of art have, if we take this passage on Greek mythology seriously, an intersubjective basis.
} 
If much Schelling literature is split between interpreting him as a protean thinker endlessly shifting in his philosophy, ${ }^{37}$ or a philosopher restlessly unfolding the consequences of one fundamental intuition, I agree with the latter. Often this fundamental intuition is seen to be a commitment to explicating the uncanny character of human freedom. To which the former group of commentators respond by pointing out that freedom- even by Schelling's own admission - was not adequately addressed in his period of identity-philosophy. Our reading of the $S T$ overcomes this objection by arguing that the $S T$ is in some sense a subversion of transcendental idealism insofar as it subordinates practical philosophy (and the tenet that freedom is an infinite progress toward an ideal) to an act that is 'more free than freedom itself: a positive freedom (to use Schelling's later terminology), an early name of which is aesthetic intuition. Aesthetic intuition and its capacity for mythological 'communitarianism,' is for Schelling, superior to practical philosophy and the emphasis on natural rights and ethical precepts (which, I might add, can be cynically read as a set of rules for governing the ownership of, and transactions of, property). Not that aesthetic intuitionor positive freedom- is immune to ideological exploitation. Schelling's appointment to the University of Berlin in 1841, to the chair in philosophy formerly occupied by Hegel, and his insistence that the material crises of the 1840 s were more importantly spiritual rather than material, earned him the enmity of his young Hegelian critics (such as Frederick Engels ${ }^{38}$ ) as a kind of Prussian philosophical revanchism.

\footnotetext{
${ }^{37}$ See, for example, Emil Fackenheim, The God Within: Kant, Schelling, and Historicity. Ed. John Burbidge (Toronto: University of Toronto Press, 1996), 50-74; and also Andrew Bowie, Aesthetics and Subjectivity: From Kant to Nietzsche (Manchester: Manchester University Press, 1990), 104.

${ }^{38}$ Frederick Engels, "Anti-Schelling," http://www.marxists.org/archive/marx/works/1841/antischelling/index.htm. For an overview of some of these debates, see Bruce Matthews introduction to Schelling's The Grounding of Positive Philosophy: The Berlin Lectures. Trans. Bruce Matthews (Albany: SUNY Press, 2007).
} 
Yet it is a long way from the $S T$ to Positive Philosophy, and Schelling's insight into the inadequacy of the Kantian-Fichtean concept of freedom is one of his important contributions to early German Idealism, presaging Hegel's criticisms of the 'bad infinity' of practical reason. In the next chapter we will continue the process of showing the continuity of Schelling's philosophy of art. Contrary to the standard interpretation, the Philosophy of $A r t$, which was written and delivered as lectures during the period of absolute idealism, maintained all the important features that we introduced as the Three Conditions of Schelling's philosophy of art. Each condition is first established in the System of Transcendental Idealism:

C1. What philosophy constructs in the ideal, art produces in the real. Thus artistic activity is the highest human vocation because practical philosophy can only approximate its object, which is the moral law.

C2. While both the natural organism and the artwork embody the same identity of real and ideal, of necessity and freedom, the work of art overcomes these oppositions through the identity of conscious and unconscious production, whereas the organism's activity is unconscious.

C3. Artistic production has a socio-political task: it aims to overcome the fragmentary condition of modernity through a new mythology and artistic renewal.

While the first principle of Schelling's system changes, all three of these conditions obtain in the Philosophy of Art. While it is true that they are no longer guaranteed by the self's activity, the relationships between nature-, practical- and art-philosophy are all supported through what Schelling calls a construction of the potencies. However, this is not our only 
interest in the Philosophy of Art. As we will see, these lectures propose a unique perspective on, and unique solution to, the central problem of absolute idealism. 


\section{Chapter 4}

\section{Substance and History: Art and the System of Identity}

\subsection{The Light of 1801}

After adjudicating the dispute between dogmatism and criticism, after delineating a naturephilosophy, and after completing, however perfunctorily, a system incorporating these concerns and those of transcendental idealism and a philosophy of art- an impressive achievement for a twenty six year old, let alone for any other professor of philosophy at Jena- Schelling did not rest. One year after the System of Transcendental Idealism (1800) had been published, he was already announcing his system: a philosophy of absolute reason, which later came to be known as 'identity-philosophy' or absolute idealism. Schelling's system, in the period from 1801-1806, held that the differences between subjectivity and objectivity, self and world, freedom and necessity, ideal and real, and providence and fate, were all grounded on a principle of identity and absolute totality. In other words, all these divisions were grounded on an absolute which encompassed all particular manifestations of reason and nature. Thus Schelling abandoned the limits of subjective idealism for the Spinozist monism of absolute idealism, wherein reason and nature are one substance. The Darstellung meines Systems der Philosophie of 1801 was the reflection of the fact that, as Schelling later recalled, he had seen the light of the philosophy that led beyond the limits of 
transcendental idealism. ${ }^{1}$ Where he had earlier held the activity of the absolute self to be the first principle of philosophy, now Schelling posits identity as such: the absolute is the indifference of subject and object: both are contained within the absolute and are only partial expressions of it (which, as we saw in Chapter Three, was suggested by Schelling's parallel systems). From the perspective of reason, all particular things are contained within the absolute; all previous divisions of philosophy comprise partial expressions of the absolute world, whether as nature, history, or art.

This transformation of Schelling's metaphysics presents serious problems for interpreters of his philosophy of art. According to the standard interpretation of Schelling's philosophical development, the philosophy of art serves as an intermediary step toward the discovery of absolute idealism, because once he worked out a philosophy of the absolute, beyond the subjective idealism of transcendental philosophy, he no longer needed a philosophy of art. This argument rests on several mistaken claims. First, that Schelling's idea of the absolute stemmed from his work on the System of Transcendental Idealism itself, which resulted in his philosophy of art. In Chapter one we saw that Schelling had presentedprobably due to Hölderlin's influence- an idea of the absolute that was neither subjective nor objective, but was the ground of this division, in the Letters of 1795-1796. One could reply, however, that this only serves to support Schelling's claim in the Darstellung that he had this idea of the absolute in mind for some time before making it public in 1801 (344/4: 107).

We introduced a stronger objection in the previous chapter: that the standard image relies on a confusion between the method of transcendental idealism and what Werner Marx has called the Bildungsgeschichte ("history of cultivation") reading of The System of Transcendental Idealism, a confusion that had its basis in Schelling's later self-

\footnotetext{
${ }^{1}$ See the letter to Eschenmayer, dated July 30, 1805, in Plitt, 2: 60-62.
} 
interpretations. The task of transcendental idealism is to demonstrate the conditions necessary for objectivity, to show how the self becomes objective, not, as Schelling later claims, a "Socratic dialogue" where the reader is initiated by the "philosophical ego" into the Elysian mysteries of philosophy (this account sounds much more like the dialogue Bruno!). If these two interpretations are not separated it is possible to hold, ironically, a much more Hegelian interpretation of Schelling's development: that identity philosophy is an overcoming of transcendental idealism, in which the results of the philosophy of art are sublated (aufgehoben). Or, as one of the more recent accounts asks, how "can we understand that art, which in the System des transzendentalen Idealismus is still called "the only and eternal revelation" of the absolute, is no longer needed?"2 The problem with this interpretation is that the philosophy of art is still needed; even if absolute philosophy constructs the world as it is through reason (and not just through subjective activity) it still requires artistic production to present this ideal activity in the real world. As I will argue, both transcendental idealism and absolute idealism rely on the faculty or power ( $\mathrm{Kraft}$ ) of the imagination, which provides the continuity between theoretical-, practical- and artphilosophy, and which produces the artwork as the real presentation of the absolute. ${ }^{3}$

It should be noted, however, that not all accounts of the transition confuse these arguments. Instead, as often signaled by its absence, they relegate the philosophy of art to a secondary significance within identity-philosophy. In this case, art is equated with subjective activity, so once the subject (self-consciousness) is no longer the first principle, art is no

\footnotetext{
${ }^{2}$ Antoon Braekman. "From the Work of Art to Absolute Reason: Schelling's Journey Toward Absolute Idealism," in The Review of Metaphysics 57 (March 2004), 554. Braekman's argument attempts to show how the philosophy of art is gradually assimilated by Schelling's metaphysics in general. By contrast, I argue that the philosophy of art maintains a central position in identity-philosophy.

${ }^{3}$ As Schelling argues in the Further Presentations from the System of Philosophy," trans. Michael Vater, in The Philosophical Forum XXXII No.4 (Winter 2001), 396/4: 410: the $S T$ "sketched the general framework of construction, whose schematism must also be the foundation of the completed system."
} 
longer central to the system. Thus in the accounts of identity-philosophy, many of the standard commentaries ${ }^{4}$ begin with the Darstellung and move, for a more systematic presentation, to the System der gesamten Philosophie und der Naturphilosophie insbesondere (1804), better-known as the Würzburg Lectures (SW, 6: 131-576, but see especially 569-576 which is a section on art and politics that we will deal with in the next chapter). ${ }^{5}$ Xavier Tilliette dedicates a chapter of his two volume work to the Philosophy of $A r t$, only to conclude that the system of art is obsolete and that the general presentation only repeats the central problems of the system of identity. ${ }^{6}$ Rather than a justification for neglect, this repetition should be a reason for investigation.

I argue in this chapter that 1) the philosophy of art is central to identity-philosophy (and therefore cannot be equated with subjective idealism) and 2) that Schelling's resolution to the central problem of identity-philosophy is not redundant, but that it presents a problematic solution that Schelling tries to resolve in the address Über das Verhältnis der bildenden Künste zu der Natur of 1807. Both parts of my argument rest on explicating Schelling's central difficulty: as he notes, the central task of identity-philosophy, since it does not begin with the finite, is to demonstrate how the transition from the infinite to the finite is possible; to show how one can show how the finite world arises within the absolute. What drives our investigation is that the deductions of nature found in the Darstellung cannot overcome the difficulties of this transition with abstract argumentation. The

\footnotetext{
${ }^{4}$ See Manfred Frank, Der Unendliche Mangel an Sein (Frankfurt: Suhrkamp, 1975), 103-119; and Eine Einführung in Schellings Philosophie (Frankfurt: Suhrkamp, 1985), 118-132; Andrew Bowie, Schelling and Modern European Philosophy (London: Routledge, 1993), 55-90; and Alan White, Schelling: An Introduction to the System of Freedom (New Haven: Yale, 1983), 81-92. The notable exception is Jean-François Marquet, who will be discussed below. Frank does discuss the section on art and mythology in Der kommende Gott: Vorlesungen über die Neue Mythologie. Vol. 1 (Frankfurt: Suhrkamp, 1982), 198-200.

${ }_{5}^{5}$ Partially translated in Idealism and the Endgame of Theory. Ed. Thomas Pfau (Albany, SUNY Press, 1994), 139-194.

${ }^{6}$ Tilliette, Schelling. Une philosophie en devenir. Vol. 1. (Paris: Vrin, 1970), 439-471.
} 
Philosophy of Art, by contrast, provides a unique attempt at resolving this difficulty by arguing that the determinations of art are the 'highest' presentations of the formation of the absolute in finite form.

Hence we have Schelling's claim that the philosophy of art "is the presentation of the absolute world in the form of art" $(P A, 350 / 5: 350)$. However, art is not just any presentation: it is the highest presentation of the absolute in the finite world because the production of artwork mediates the separation of necessity and freedom and overcomes this separation in the finished work. Therefore, artistic production is the real presentation of the identity of reason and nature, of the ideal and the real. Of course, these arguments should be familiar from the System of Transcendental Idealism, though now extended to identityphilosophy: absolute idealism still recognizes artistic production as the real counterpart to the ideal activity of philosophy. In showing how many of the features of art found in the System of Transcendental Idealism are now adapted to identity-philosophy, it is possible to show how the philosophy of art maintains a privileged place in Schelling's thought.

Yet our interest is not limited to how Schelling retains the structural importance of his philosophy of art vis-à-vis absolute idealism in general. We are also interested in a solution to the problem of the transition from the infinite to the finite: in the Philosophy of Art he proposes that the imagination informs the infinite into the finite through both the content and the particular forms of art. In this chapter we will focus on the historical construction of the content of art, in which Schelling argues that the content of art has its basis in either Greek mythology or what he calls Christian mythology. What makes this account interesting is how the historical construction of the gods (and the Christian God) presents the polytheism of imagination and art as being at odds with the monotheism of 
reason (to paraphrase the "System Program"; see Chapter 2.6). A contradiction between substance and history: while the system of identity is grounded on a Spinozistic God, the historical construction of art presents a series of revelations within history. ${ }^{7}$ As I will argue, Schelling makes no attempt to reconcile these differences and instead elides them to provide an account that superficially follows his requirement that essence and form be identical. But if essence and form in general are the eternal substance, while the essential content is historically revealed, then history exceeds the formal structure of the philosophy of identity. Schelling will not resolve this problem until 1807 , but it is crucial to see why this problem leads to (or at least contributes to) the abandonment of identity philosophy. The crux of the matter is the hypothetical form of the system.

While our approach is limited primarily to the Darstellung and the Philosophy of Art, it should be noted that Schelling's identity-philosophy is not, despite appearances, a complete relapse into Spinozist dogmatism. ${ }^{8}$ Instead, Schelling attempts to maintain a critical approach in the justification of his system, by noting that the principle of absolute identity is a necessary presupposition of philosophy. ${ }^{9}$ This critical approach is most evident in the Würzburg Lectures, where he provides an indirect proof of the principle of identity "by demonstrating that knowledge remains inconceivable under any other presupposition" (141/6: 138). As Manfred Frank notes, however, Schelling's proofs for absolute identity

\footnotetext{
${ }^{7}$ Jean-François Marquet discusses these developments but does not thematically treat them as a central contradiction within the system of identity-philosophy. See Liberté et existence. Second Edition (Paris: Les Éditions du Cerf, 2006), 238-277. By substance, in this context, I refer primarily to the eternal, monist form. ${ }^{8}$ Nor should this reading be taken as exhoustive of identity-philosophy. As Jean-François Marquet notes, the various presentations over the years 1801-1806 are too similar to make it necessary to study each separately and too different to extract a single system-formula supporting each. Liberté et existence. Second Edition (Paris: Les Editions du Cerf, 2006), 208. See also Frederick C. Beiser, German Idealism: The Struggle Against Subjectivism 1781-1801 (Cambridge, Mass., Harvard: 2002), 560-564.

${ }^{9}$ See Vorlesungen über die Methode des akademischen Studiems, which is concurrent with the lectures given as the Philosophy of Art. Translated as On University Studies. Trans. E.S. Morgan (Athens, Ohio: Ohio University Press, 1966), 9/5: 215.
} 
remain mostly negative and that a positive concept is more elusive. ${ }^{10}$ Frank writes: "What, in the beginning of philosophizing, can only be a hypothesis, must not, in the process, remain a hypothesis. In the concept of every beginning lies a lack. Removing [the lack], by proving the hypothesis, is the motive for the process of philosophical reflection. Only at the end can what, at the beginning was hypothetically established, be grounded."11

Our reading of the Philosophy of Art puts Schelling's hypothesis to the test: the justification for the idea of absolute identity relies on the result that will show how the system forms a totality that does not contradict the identity of essence and form. I will argue that Schelling's attempt to construct a philosophy of art overflows the formal structures of identity-philosophy. In other words, the plenitude of art pushes Schelling to abandon the strictures of identity-philosophy (its 'initial hypotheses') for a more historical approach found in the address Über das Verhältnis der bildenden Künste zu der Natur of 1807.

\subsection{The Turn to Absolute Reason}

We will begin with the Darstellung because it outlines Schelling's break with Fichte and transcendental idealism. It is with the Darstellung that Schelling announces his system of philosophy, one that, in the preface, he says has come too soon and yet has served as the "guide-star in both transcendental and natural philosophy (344/4: 107)." This philosophy of identity, his philosophy, attempts to elucidate philosophy from the standpoint of absolute reason itself, from a point indifferent to subjectivity and objectivity. In a letter to Fichte, as their debate was escalating, Schelling himself indicates that this standpoint was first

\footnotetext{
${ }^{10}$ See Frank, Eine Einführung in Schellings Philosophie, 118-132; and Beiser, German Idealism, 577-582, 588593.

${ }^{11}$ Frank, Eine Einfuihrung in Schellings Philosophie, 123.
} 
mentioned in his Letters; ${ }^{12}$ and as I discussed in Chapter 3, it seems to be implied in the Introduction to the System of Transcendental Idealism. However, if this is correct, Schelling is placed in the unenviable position of explaining why he kept the ground of his system in the shadows. To this question he replies that his previous work served as a propaedeutic, a "preparation for the integral reception of this philosophy" (334/4: 107).

From the standpoint of the Darstellung, it would seem that Schelling's previous goal was to exhaust the possibilities of transcendental idealism, to expose its inner problems, as a path to absolute idealism. As I have argued, the task of the System of Transcendental Idealism consisted of subordinating Fichte's practical philosophy to a higher principle, which was aesthetic intuition. Yet, despite the assertive tone of the Darstellung Schelling does not yet directly confront Fichte, stating that "I think it is impossible that we not eventually come to agreement, even if now, at least in my opinion, this point has not been reached" (346/4: 110). Schelling remained optimistic, though he seemed to have misjudged Fichte, who seems only to be able to read Schelling as a disciple and not as an equal. Then again, this kind of confidence is a foregone conclusion of the system itself: regardless of the possessive description of the system, the Darstellung argues that reason, and hence a philosophical system, is universally valid beyond the contingencies of the individuals who do philosophy.

However, while Fichte saw that the Wissenschaftslehre was troubled by the problem of accounting for the intelligible world, he would not- since he did not develop a system like

\footnotetext{
${ }^{12}$ Schelling to Fichte, October 3, 1801. Excerpts are translated in Theory as Practice. Ed. Jochen SchulteSasse, et al. (Minneapolis: University of Minnesota Press, 1997), 73-90; Fichte: Gesamtausgabe der Bayerischen Akademie der Wissenschaften, III, 5: 85.
} 
Schelling's- recognize how Schelling arrived at the system of identity-philosophy. ${ }^{13}$ As suggested in the System of Transcendental Idealism, neither transcendental philosophy nor nature-philosophy can ground the standpoint from which they can be presented as parallel constructions within a larger system capable of grounding the principles of subject and object. ${ }^{14}$ Both transcendental philosophy and nature-philosophy cannot grasp the absolute as identity between subject and object, and, while this identity is represented in art-philosophy, it is difficult to ascertain the discourse from which it becomes possible to articulate this identity of the absolute, unless it is already the discourse of philosophy itself. If one starts from the subject alone- or the object alone- as the standpoint of thinking, one cannot grasp the absolute totality of reason. Schelling states, as a "possibility," that Fichte is confined to the standpoint of subjective idealism, which is constrained to an epistemology based in reflection, and thus cannot reach the perilous heights of the absolute. Fichte, as discussed in Chapter 1.3 , does begin with the law of identity $(A=A)$ as the first principle of philosophy but in the Wissenschaftslehre, he held that this principle was regulative: although identity was the basis of the system, posited as an act of the self, it could only be justified practically. This is because the first principle of identity is mediated by those of negation (the not-self) and limitation. The first principles of the Wissenschaftslehre present a contradiction that the remainder of the work attempts to resolve: that the self posits itself as determining the notself, and that the self posits itself as determined by the not-self; and he argues that theoretical philosophy cannot resolve this contradiction between the demand that the self determines the external world and that the finite self necessarily feels itself limited within the world. In the

\footnotetext{
${ }^{13}$ Fichte to Schelling, December 27, 1800. Fichte finally accuses Schelling of dogmatism in his response to Schelling's letter of October 3, 1801. See Fichte: Gesamtausgabe der Bayerischen Akademie der Wissenschaften, III, 4: 406-407; III, 5: 90-93.

${ }^{14}$ Although Schelling states that it should be possible for transcendental idealism to do so (ST, 2-3/3: 331).
} 
practical part of the Wissenschaftslehre, Fichte attempts to resolve the contradiction between self and not-self with a philosophy of striving, with the imperative that the self ought to act in such a way that is in conformity with itself.

With the Darstellung, Schelling no longer conceives of the absolute as a self, nor does he conceive of it as regulative. His explicit model becomes Spinoza, who "came nearest my system in terms of content or material and in form" (348/4: 113). Of course, this raises the question: which Spinoza? As we have seen, Schelling's use of Spinoza has never been a clear and consistent practice. In the Letters, we were confronted with a dogmatic Spinoza who begins from the first principle of the Object and whose thought both interprets the world through mechanism, and also proposes an ethic of the intellectual love of God. In the Ideas, we discovered a Spinoza who first glimpsed a monistic principle grounding the dualism of thought and being, who held to the doctrine of the attributes. And then, in the First Outline, a Spinoza whose importance resides in correctly interpreting nature as both producing (natura naturans) and product (natura naturata).

But should we conclude that identity-philosophy is nature-philosophy writ large? In the interim between the System of Transcendental Idealism and the Darstellung, Schelling pursued the realist implications of his nature-philosophy, and even drew the conclusion that 'nature philosophy gives a physical explanation of idealism' (4: 76). So, if for Fichte (and Kant), reason is something that the subject imposes on nature, or, strictly speaking, something that the subject can only know as an imposition on nature as a regulative ideal, for Schelling, as an absolute idealist, reason operates within nature, or, reason is identified with nature. But what is the meaning of this apparently naturalist principle? Marshalling evidence from this essay (the Allgemeine Deduktion des dynamische Phyik, from 1800 [SW, 4: 1-78]) 
and others from this brief period, Frederick C. Beiser argues that objective idealism is "nothing less than the standpoint of the Naturphilosophie itself, an absolute or transcendental realism and naturalism." 15 Yet using the same evidence, Tilliette concludes that identityphilosophy is neither nature-philosophy nor transcendental idealism, but a system that grounds both. ${ }^{16}$ While there is no doubt that Schelling takes the world of nature seriously, we will see that identity-philosophy is not just a kind of transcendental realism or naturalism (this would, according to Schelling, relapse into dogmatism), but a system that demonstrates that the real and ideal worlds are identical in the absolute, through a genetic construction of the world and not a transcendental inquiry.

In the Darstellung a transcendental framework, grounded in the subject's activity, is jettisoned in favor of constructing proofs through axioms, remarks and corollaries, even if Schelling's preface proceeds with some pretense to giving a transcendental inquiry into the possibility of subjectivity and objectivity. It should be noted that his use of the terms 'subject' and 'object' is ambiguous: in the preface, he claims to be grounding the parallel systems of transcendental idealism and nature-philosophy (and their parallel first principles) in a system of identity or absolute reason, but in the deductions and proofs themselves, he is talking about individuals as ideal or real potencies (that is, emerging from the absolute as particular and finite beings). Despite the architectonic ambiguity for the system itself, it becomes clear that Schelling draws from Spinoza's doctrine of the attributes: that the absolute is one, although it is expressed in ideal or real terms. Schelling then, does not proceed from the Object as a first principle, nor does he interpret the world through the

\footnotetext{
${ }^{15}$ Beiser, German Idealism, 557.

${ }^{16}$ Tilliette, Schelling. Une philosophie en devenir, Vol.1, 254. See also the comment of a contemporary critic of Schelling in Michael G. Vater, "Introduction" in Bruno, or, On the Natural and the Divine Principle of Things. Ed. Michael G. Vater (Albany: SUNY Press, 1984), 55: "Schelling is reproached with almost always being in suspense between idealism, realism, and even materialism."
} 
concept of mechanism. Instead, the standpoint of absolute reason is indifference [Indifferenz].

As stated in the opening paragraph of the Darstellung, Schelling defines absolute reason as the "total indifference of the subjective and objective" (349/4: 114). So "absolute reason,' which he claims is identical to the totality of the universe, is total indifference, but we are no closer to what indifference is. Our examination of the Darstellung, then, must focus on the concept of indifference, and then, the relationship between indifference and finitude (as subjectivity or objectivity). This first paragraph provides us with several negative definitions of indifference: it is not subjective, thus neither a psychological state ${ }^{17}$ nor limited by finitude of subjectivity; it is not objective, conceived as succession, mechanism, or externality. ${ }^{18}$ The problem though, for Schelling, is to define indifference 'positively,' aside from a totality that includes, but is not identical to, subject and object. To state this in another way, even if Schelling can show that indifference, or the absolute, includes subject and object but is not identical to them, he must still show how finitude arises within it. To do this, he will introduce a theory of 'potencies' which express the quantitative difference of finite beings as predominately ideal or real. As I will argue, despite introducing a dynamic physics within his neo-Spinozist system, he cannot show the transition from the infinite to the finite, which will be addressed in a different manner in Schelling's Philosophy of Art.

Let us then continue with the Darstellung. As totality, Schelling argues, there can be nothing outside the absolute, that is, there can be no qualitative difference between the

\footnotetext{
${ }^{17}$ Michael Vater, the translator, points out that "Indifferenz is borrowed from English; [Schelling] means "indifference to be a logical operator; not a psychological descriptor like Gleichgultigkeif" (343).

${ }^{18}$ As mentioned in Chapter 3, Schelling contrasts absolute identity and relative identity (indifference), when he establishes as an axiom that "No identity in Nature is absolute, but all is only indifference" (First Outline, 220/3: 309). In this context, indifference is defined as equilibrium between opposing forces.
} 
absolute and the finite. Recall that the categories of quality include reality, negation and limitation. While the absolute is real, it can neither be negated nor limited in its being, if it is to be absolute (360/4: 130). ${ }^{19}$ Instead, Schelling argues that the ground of finitude is quantitative difference, ${ }^{20}$ and he calls this difference an individual's potency (Potenz). Like many of the other terms he attempts to define in this premier text of the system of identity, he struggles with a clear definition of potency as well, describing it as an individual's "amount of being" or "magnitude of being" [Größe des Seyns] (355/4: 123). Each individual shows a predominance of either subjectivity or objectivity (or, in other terms, ideality or reality) but never only one (because the central question of the inquiry is explaining the relationship between these terms). Schelling designates, in distinction to the law of identity $(A=A)$, potency as $A=B$, where $A$ is the cognizing principle and $B$ is the real principle. As finite (" $A=B$ is generally the expression of finitude"), a potency contains both a relative unity and quantitative difference. Schelling writes:

Since $\mathrm{A}$ is the cognizing principle, while $\mathrm{B}$, as we shall discover, is what is intrinsically unlimited or infinite extension, we have here quite precisely both the Spinozistic attributes of absolute substance, thought and extension. We do not merely think these attributes are identical ideally (idealiter), as people commonly understand Spinoza, we think them completely identical in reality (realiter) [...] Thought and extension are thus never separated in anything, not even in thought and in extension, but are without exception together and identical (364/4: 136).

It is formulations like these that prevent us from deciding whether Schelling, like Spinoza, naturalizes thought or idealizes nature (recall the discussion above about Schelling's naturalism or realism). Giving one priority seems to violate his doctrine (of the attributes) that substance be thought as both actually ideal and real. And with this problem of monism,

\footnotetext{
${ }^{19}$ This is an important difference with both Fichte, who, while deducing the activity of the absolute subject, also deduces the categories of quality (see Chapter 1.3), and, of course, Hegel, for whom negation is the activity of thought itself.

${ }^{20}$ Recall that for the Kantian categories, quantity includes unity, plurality and totality.
} 
he encounters another problem shared with Spinoza: the transition from the infinite to the finite: Schelling holds that the absolute admits of no qualitative or quantitative difference whatsoever, but also that individuals differ according to their magnitude of being (their potency). To resolve this contradiction, he argues that subjectivity and objectivity are posited in opposite tendencies, which consequently means that for each predominately subjective potency is counterbalanced by one that is predominantly objective. He states that the absolute's "form of being can thus be universally conceived through the image of the a line":

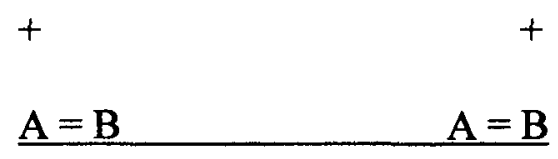

$$
\mathrm{A}=\mathrm{A}
$$

In this line, one tendency $(+A=B)$ proceeds toward the subjective while $(A=B+)$ proceeds toward the objective, and both are grounded in the indifference of the absolute (365/4: 137). This is the basic model of the potencies and their relationship to the absolute. Additionally, each potency contains both a relative identity and a relative difference, so each potency is, in its existence, isomorphic to the absolute. ${ }^{21}$ As we will see, they can also be arranged hierarchically, so some potencies are higher than others.

This dynamic account of potencies is Schelling's attempt to maintain Spinoza's monism while dispensing with the latter's dependency on mechanism (and, consequently, the use of the principle of sufficient reason). ${ }^{22}$ However, the lack of a concept for the qualitative difference between infinity and finitude forces Schelling to argue that quantitative

\footnotetext{
${ }^{21}$ Schelling's proof: "every point [on the line] can also serve as indifference-point relative to some other, or become now one, now the other of the two opposed end poles" because the line is infinitely divisible, as it is grounded in the absolute (365-366/ 4: 137-138).

22 After the construction of the potencies, Schelling goes on to deduce the central concepts of naturephilosophy. See Marquet, Liberté et existence, 215-223, who notes how some of Schelling's deductions formally anticipate those of his later work.
} 
differences are nothing but appearances and not noumena, that is, differentiation appears to the subject the standpoint of reflection (357/4: 126). This stance leads Alan White to note that Schelling's system of identity is "as homogenous and undifferentiated as the Parmenidean one":

While opposition is thus beneath the system of identity, differentiation cannot be, or no system would be possible, for there could be no systematic content. Yet if the absolute exists at all, Schelling insists, there must be content: while the essence of the absolute is undifferentiated identity, the form in which the absolute exists is an identity of distinct element' the absolute exists as identity only if it is the identity of something [see 353-354/4: 120-121]. ${ }^{23}$

From the perspective of reason, it appears that all differences are swallowed up by the absolute. And yet, at the same time, Schelling's concept of potency provides a conceptual basis for the plenitude within the totality. As Valerio Verra notes,

Each idea incarnates all the others, not in an indifferent and interchangeable fashion, but following an ascending order of "potentialization" that culminates in absolute identity, an identity, however, which is not empty, but rich in articulations, tensions and differences. Such a point of view makes it understood that the relationship of the universal and particular becomes more rich, more complex and more concrete than the simple logical or reflected distinction between concept and intuition. ${ }^{24}$

While the Darstellung struggles to account for the finite content, as it were, of the potencies, and the infinity of the absolute, the Philosophy of Art will utilize a more developed conceptual vocabulary in the attempt to reconcile the whole and its parts. The promise, at the end of the Darstellung to more fully develop "highest expressions of indifference," which are Truth and beauty (4:212), is fulfilled in the lectures collected as the Philosophy of Art.

\footnotetext{
${ }^{23}$ White, Schelling, 77. Not even Beiser, who is much more sympathetic to Schelling's work, can resist the Parmenidean image in his German Idealism, 565.

${ }^{24}$ Valerio Verra, "La 'construction' dans la philosophie de Schelling," in Actualité de Schelling. Ed. G. PlantyBonjour (Paris: Vrin, 1979), 38.
} 


\subsection{The Relationship between Art and the Absolute}

The Philosophy of Art, which is based on lectures given in Jena in 1802-1803, and then in Würzburg in 1804-1805, is an underappreciated work in Schelling's oeuvre. As JeanFrançois Marquet notes, Schelling stated that the lectures later collected under this title should not be published, with the exception of the section on tragedy, advice which was not taken by his son and editor after Schelling's death, a fortunate turn of events, because without the Philosophy of Art we would lack an important link between the System of Transcendental Idealism and his turn away from identity-philosophy found in Über das Verhältnis der bildenden Künste zu der Natur of $1807 .^{25}$

If the Philosophy of Art is not overlooked, it has also been criticized for its lack of originality. Surprisingly, one of the more disparaging readings comes from Xavier Tilliette, who is usually a discerning critic. Tilliette finds the text limited in its scope, hastily composed, and reliant on the work of others such as Schiller, Hölderlin, Goethe, and Moritz. ${ }^{26}$ Tilliette's central disappointment seems to come from Schelling's subordination of mythology to the purposes of the philosophy of art. ${ }^{27}$ Overall, Tilliette finds very little of interest in Schelling's presentation of the absolute in the form of art. ${ }^{28}$

I will argue, by contrast, that the Philosophy of Art is an important step in Schelling's development. While it is true that his text borrows from his contemporaries, Schelling does

\footnotetext{
${ }^{25}$ Jean-François Marquet, "Schelling et le destin de l'art," in Actualité de Schelling. Ed. G. Planty-Bonjour (Paris: Vrin, 1979), 75. Frank Fischbach argues that Schelling's disdain for these lectures arose from their retrospective proximity to Hegel's Aesthetics, but while Fischbach notes the similarities, there are numerous differences as well that undercut his hypothesis. See Fischbach, "Differrence et correspondence entre les arts chez Hegel et Schelling," in Hegel Jahrbuch 1999: Hegels Ästhetik. Vol. 1. Ed Andreas Arndt, Karol Bal and Henning Ottmann (Akademie Verlag, 2000), 185-195.

${ }^{26}$ Tilliette, Schelling. Une philosophie en devenir, Vol.1, 444-445. For more on Moritz's influence on Schelling via Goethe, see George S. Williamson, The Longing for Myth in Germany (Chicago: University of Chicago Press, 2004), 38-40, 44, 60.

${ }^{27}$ Tilliette, Schelling. Une philosophie en devenir, Vol.1, 449.

${ }^{28}$ This negative judgment is somewhat moderated in Tilliette's La mythologie comprise (Naples: Bibliopolis, 1984), 31-45.
} 
so because he is doing much more than constructing a critique of taste, an empirical theory of art, or an aesthetics; Schelling is constructing a philosophy of art by extracting artistic ideas from the multiplicity of art. ${ }^{29}$ This means that the philosophy of art is not just a philosophical approach to a particular object, like a philosophy of automobiles or a philosophy of agriculture, ${ }^{30}$ but art is worthy of philosophy because it has something to present of the absolute.

This requires beginning with the relationship between philosophy and art, or, to approach this question in Schelling's terms, beginning by asking how a philosophy of art is possible. Ultimately art-philosophy is possible because art presents the absolute in sensible form. As Schelling states, the philosophy of art "is the presentation of the absolute world in the form of art" $(P A, 7 / 5: 350)$. While these kinds of statements are similar to those found in the System of Transcendental Idealism, Schelling no longer has the "history of selfconsciousness" to justify the philosophy of art. That is, transcendental idealism follows the activity of the self as it strives to produce the absolute, which ultimately results in the production of the work of art through aesthetic intuition. The metaphysics of identityphilosophy dispenses with what Schelling now calls subjective idealism.

In the Philosophy of Art, the problem of this relationship can be resolved in two interrelated steps: the first is to determine the place of art in the system, and the second is to determine why this relationship obtains. As in the System of Transcendental Idealism, Schelling identifies three domains of philosophy: nature-philosophy, the philosophy of history, and the philosophy of art $(P A, 15 / 5: 367 ; 29 / 5: 382)$, which correspond to a

\footnotetext{
${ }^{29}$ For more on the comparison between an aesthetic and a philosophy of art, see Pascal David, "Schelling : construction de l'art et récusation de l'esthétique," in Revue de Métaphysique et de Morale 2 (2002), 179-191.

${ }^{30}$ See $P A, 14 / 5: 365$. Of course Schelling does not say automobiles; he refers to a "Philosophie des Fuhrwerks" (a philosophy of the wagon).
} 
predominance of the real (as knowledge), a predominance of the ideal (as action) and their indifference (as art). These divisions also obtain as Ideas: truth, ${ }^{31}$ the Good, and Beauty. ${ }^{32}$ Thus, for Schelling, to explain art from the standpoint of understanding (or from the standpoint of morality) reverses the order of the potencies: a proper appreciation of art requires explaining beauty by something superior; it requires what we have already noted as the construction of the philosophy of art. Though art is the highest potency of the ideal, only philosophy in general can deduce truth, virtue (Sittlichkeit), and beauty from a common source, because philosophy in general explicates the rational structure of the absolute itself. ${ }^{33}$

Now that we have sketched out the systematic relationship between art and philosophy in general, we come to the much more difficult problem: why, and how, does this relationship obtain? Schelling's argument is not the most straightforward, but it hinges on several crucial concepts, drawn from a vocabulary that he develops after the Darstellung: Einbildungskraft, Ineinsbildung, and the opposition between Urbild and Gegenbild. This vocabulary is largely developed because Schelling cannot rely on the much more traditional philosophical vocabulary of representation. The most obvious example of his critique of reflection can be seen in Schelling's use of "presentation" (Darstellung and its cognates) to describe the embodiment of the absolute in the finite, in contrast to "representation" (Vorstellung). To take up ideally the infinite from the particular is what Schelling calls construction, which happens not through the understanding (the faculty of representation)

\footnotetext{
${ }^{31}$ We will distinguish between 'truth' as the correctness of propositions about the natural world from 'Truth' which is absolute, the archetype of truth in its identity with beauty. "Truth that is not beauty is also not absolute truth, and vice versa" ( $P A, 31 / 5: 385)$.

${ }^{32}$ Note that Schelling also mentions the organism as an example of beauty. We will return to the relationship between natural organisms and artworks below. See $P A, \S 11$.

${ }^{33}$ Schelling again complicates this presentation by stating that "reason and philosophy can relate to one another as real and ideal. Since, however, each in itself is absolute identity, this relationship does not constitute any real difference [my emphasis]. Philosophy is merely reason that has become or is becoming aware of itself; reason is merely the matter or objective model of all philosophy" ( $P A, 28-29 / 5: 381)$.
} 
but through reason itself. Philosophy is interested in art "only to the extent that it takes up the entire absolute within itself and presents [darstellt] it in itself" $(P A, 15 / 5: 367)$. Philosophy constructs a philosophy of art by intuiting the universal within the particular; by extracting the ideas of art from the sensible presentation. Construction is the determination of the "one and undivided whole of philosophy in its various potencies or from the viewpoint of various ideal determinations" $(P A, 14 / 5: 365) .{ }^{34}$ Therefore, the choice of "representation" by the translator of the English edition is misleading. To translate 'Darstellung' as representation implicitly contravenes Schelling's order of potencies, which progress from knowledge (the standpoint of the understanding) to action (praxis), to art (the indifference of the two) $(P A, 28 / 5: 380)$.

Less problematic is the term Einbildungskraft, the imagination, which Schelling defines as the act that realizes, in the concise formulation of Orrin F. Summerell, "the unification of the disparate and the information of the formless." 35 Schelling states that Einbildungskraft "means the power of mutual informing into unity (Ineinsbildung) upon which all creation is really based" ( $P A, 31-32 / 5: 386)$. The importance of imagination within the system of identity becomes clearer when contrasted with the activity of construction. The latter is the ideal intuition of the universal in the particular, in the terms of the Philosophy of $A r t$, to intuit the archetype in the particular. Hence construction is the central task of philosophy qua science of reason. Imagination is the real counterpart of construction: the informing (Ineinsbildung) of the infinite into the finite, whereby the ideal becomes predominantly real. Imagination is the process in which reason is grasped as sensible

\footnotetext{
${ }^{34}$ For more on construction, especially in relation to Kant, see Verra, "La 'construction' dans la philosophie de Schelling," 27-47.

${ }^{35}$ Orrin F. Summerell, "The Theory of the Imagination in Schelling's Philosophy of Identity" in Idealistic Studies, Vol. 34, no. 2 (2004), 89. My argument is indebted to Summerell's analysis of Schelling's concept of imagination.
} 
intellection. Summerell summarizes why art is the highest potency, the highest determination of particular things:

The imagination is, then, not simply one faculty among others; it is instead for Schelling the capacity which underlies everything in its being, the very dynamic of the absolute itself as the identity conditioning all opposition. Viewed in this sense, imagination is the creative force of identity, the idenitifying of identity. In the work of art as a product of imagination, then, identification is concretely at work in displaying the original determination of things as what they actually are. ${ }^{36}$

The role of imagination challenges the common interpretation that Schelling discarded or demoted the role of artistic production in the transition between the System of Transcendental Idealism and absolute idealism (see Chapter 3.1 and 3.4). Just as the final division of the System of Transcendental Idealism revealed the productive imagination (aesthetic intuition) as the basis of the continuity of the "history of self-consciousness," the system of absolute idealism holds imagination to be the highest determination (potency) of finite things. The flaw in the earlier system was not aesthetic intuition, but subjective idealism; the role of artistic production/creation is maintained as the real counterpart to philosophy (whether Schelling in 1800 or 1803 , art is the real counterpart to intellectual intuition). The imagination forms the basis of determination; it renders determination possible as knowledge or action; it presents the identity of the real and ideal, or the identity of freedom and necessity. The "organic work of nature" also presents the indifference of the real and ideal but the organism does not present the relationship as an antithesis. ${ }^{37}$ The artwork is superior to the organism because it overcomes (aufgehoben) the separation of

\footnotetext{
${ }^{36}$ Summerell, "The Theory of the Imagination in Schelling's Philosophy of Identity," 89. My only problem with this account is Summerell's use of the term 'faculty' which implies that imagination is a faculty of a subject.

${ }^{37}$ The triplicity real-ideal-indifference recurs in nature as matter (being) - light (activity) - and the organism, which "constitutes such a condition of indifference, since its essence as an organism is inseparable from the subsistence of its form, and since being also immediately constitutes activity within it" ( $P A, 27 / 5: 379)$.
} 
freedom and nature, informing them into a totality. ${ }^{38}$ Far from being a mere artifice, Schelling argues that, as the informing of the infinite into a unity of freedom and necessity, art is the real presentation of "the forms of things as they are in themselves" $(P A, 32 / 5: 387)$.

This argument, however, returns us to the division between the infinite and the finite, between reason and imagination, between the absolute and the multiplicity within it. Is it not the case, the objection would proceed, that Schelling is holding that both finitude is appearance (just as in the Darstellung of 1801) and now, as a product of imagination, a thing as it is in itself? Is this not a contradiction? We should concede that this remains a difficulty for Schelling, but note that the temporary solution in the Philosophy of Art is that each particular thing is a universe within itself: "there can be no particular things within the True universe except to the extent that they take up the entire undivided universe into themselves, and are thus themselves universes" ( $P A, 33 / 5: 388-389) .{ }^{39}$ Where the Darstellung pursued a Spinozist more geometrico in its deductions, the Philosophy of Art relies on a combination of Neoplatonism (with the archetypes) and Leibnizian monadology (that each particular thing is a "universe unto itself."). His Neo-Platonic answer leads us to the conceptual pair of Urbild-Gegenbild.

The products, as it were, of construction and imagination correspond to Schelling's opposition of Urbild and Gegenbild. The archetype (Urbild) is constructed by philosophy as enduring form, and it is presented as a particular through artistic production as Gegenbild. ${ }^{40}$ As Schelling states, philosophy is the immediate presentation of reason as such and art is the

\footnotetext{
${ }^{38}$ Recall that, in the System of Transcendental Idealism, theoretical philosophy was grounded in an unconscious producing of subject and object, practical philosophy demonstrated freedom and necessity as an antithesis, and art-philosophy overcame this antithesis through the production of the work of art.

${ }^{39}$ Schelling's answer in the Würzburg Lectures introduces the concept of an 'absolute life.' See Frank, Eine Einführung in Schellings Philosophie, 118-132.

${ }^{40}$ Compare to the Bruno's distinction between philosophy as esoteric and art as exoteric (Bruno, 131-133/4: 230-232).
} 
immediate presentation of "indifference as such" $(P A, 29 / 5: 381)$. Gegenbild is a difficult term to translate without relating it to reflection. The translator of the English edition chose 'reflected image,' but, as I mentioned above regarding Darstellung, this translation introduces ambiguities into Schelling's critique of reflection as the standpoint of philosophy. While this point has been overlooked in English commentaries, it has been debated by the French commentators. ${ }^{41}$ Literally, the term could be translated as 'counter image' or 'reflected image,' but following Marquet's example, I will suggest the term 'perfected image. ${ }^{, 42}$ This has some basis in one of Schelling's brief arguments for the superiority of art as the highest potency. To paraphrase: the degree of reality or perfection increases to the extent that it approaches its own absolute idea, and as the information of beauty, art, despite its finitude, has the most immediate relationship to the idea. Thus art is the perfected image $(P A, 29 / 5:$ 381-382). This is not, however, merely a translation issue: Schelling's terminological choices reflect his difficulty in unifying his system. No matter the translation, it strikes me that Gegenbild is a general placeholder for the two modalities of the presentation of the absolute in the form of art, according to whether the artwork is ancient or modern.

Before turning to the relationship between ancient and modern art, we should pause to note that we have completed our reconstruction of Schelling's construction of the philosophy of art in general. We have established the basic foundation of the philosophy of art as it is included within identity-philosophy. After the construction of the philosophy of art in general, Schelling continues to a historical construction of the content of art and a

\footnotetext{
${ }^{41}$ Jean-Marie Vaysse utilizes "effigie parfaite" and Fischbach "reflet image" instead of Jean-François Courtine's choice of "contre-image." See Vaysse Schelling. Art et mythologie (Paris, Ellipses, 2004), 41; and Fischbach, "Différence et correspondence entre les arts chez Hegel et Schelling," 188 and 194 n. 21. ${ }^{42}$ Marquet leaves the term untranslated in the chapter "Le modele et l'image" with the exception of once, where it appears as "image parfaite." See Liberté et existence, 238-277; in particular 274.
} 
deduction of the particular forms of art. In this chapter, we will focus on the historical content of art, which is derived from Greek mythology and Christian mythology. The deduction of the particular forms will be discussed in Chapter 5.2.

It is in the historical construction of the mythological content of art that a contradiction between the monotheism of reason and the polytheism of imagination appears. Not that Greek mythology is identified with polytheism and Christianity with monotheism and reason, but that Schelling grounds identity-philosophy in a Spinozistic God, while also providing a historical construction of the content of art as a mixture of 'living' gods, as it were, a mixture of Greek deities and Christian revelation. That the lecture Über das Verhältnis der bildenden Künste zu der Natur (1807) collapses these distinctions between art and philosophy in general, as content, and as form, is the clearest proof that Schelling has abandoned the foundations of identity-philosophy. Thus, we will focus on the historical construction of the mythological content of art within identity-philosophy, and the highest expression of art, which is Greek tragedy. In the next chapter, in order to demonstrate Schelling's abdication of identity-philosophy, we will compare the real series of the Philosophy of Art (music-painting-sculpture) with the deduction of the plastic arts found in the Discourse of 1807.

\subsection{The Gods of Art}

To establish the contradiction between identity-philosophy and historical construction we will begin with the monotheism of reason, or, the first principle of absolute-idealism. While Schelling has replaced the neutral name of the absolute with 'God,' this God of reason is still Spinozistic. The terminology has changed from the Darstellung but the essence/form has 
remained the same: God is the indifference of the real and ideal, a simultaneous selfaffirmation and being affirmed. However, 'affirmation' does not make God a living, personal God, because, as indifference, God is neither conscious nor unconscious, neither free nor necessary $(P A, 23-24 / 5: 373-374)$. As already mentioned, these divisions and differences require a separation within the totality and only form a relative unity and not an absolute unity. God is absolute unity, and as Schelling states later while discussing Dante, the ultimate revelation of Paradiso is "the vision of the colorless, pure substance of the deity itself' ( $P A, 246 / 5: 162)$. So Schelling has yet to bring forth the living God in the center of the system: he is right to claim in the Philosophical Investigations into the Essence of Human Freedom that freedom, good and evil, and personality had not yet been considered (HF, 4/7: 334), because identity-philosophy (excepting, he says, Philosophy and Religion of 1804) retained a Spinozist God. ${ }^{43}$

This distinction is important because the transition from the infinite to the finite should follow the identity of essence and form. And it does not: the separation of Greek antiquity from Christianity, and the closure of antiquity in Christian revelation, forms a disjunction that is not overcome within the system. While Schelling holds that the transition from one to the other can be understood as a shift in the predominance from the real to the ideal, this cannot explain the closure of the world of antiquity, which can no longer be actual, and the beginning of historical time in Christianity, nor can these changes be reconciled with the eternity of Spinozist substance. This will lead, as we will see in the next chapter, to the abandonment of the formal structure of identity-philosophy.

\footnotetext{
${ }^{43}$ It is interesting, though, that Schelling's discussion of language in the Philosophy of Art touches on the idea, developed later, of God's word as the living word of creation. However, where the Freiheitsschrift argues that God's revelation brings to form the chaos of nature, here Schelling writes that "Language as the infinite affirmation that expresses itself in a living fashion is the ultimate symbol of chaos eternally residing in absolute knowledge" ( $P A, 101 / 5: 484)$.
} 
Thus, without resolving these tensions, we will attempt to provide the strongest account that the Philosophy of Art offers. Schelling elides the problem between substance and history (or, the neutral absolute and an inchoate, positive system ${ }^{44}$ ) through his 'monadology,' in which he argues that a particular thing is universe within the True universe, and to the extent that things are both particular and a totality to themselves, they can be considered as ideas $(P A, 33 / 5: 388-389)$. These ideas viewed as real, through being informed by art, are the gods. Recall the distinction between Urbild/Gegenbild: "What ideas are for philosophy, the gods are for art" $(P A, 35 / 5: 390)$.

Hence the gods are the realization of the ideas of reason, which, like ideas, form a totality of a world. This realization will be unique for both Greek mythology and Christianity. Greek mythology is, for Schelling, a symbol of the absolute, while Christianity presents an allegory of the absolute. That Greek mythology has taken on a great importance in his work can be seen in comparison with his brief remarks found in the conclusion of the "Survey" of 1798, where he states that "Greek mythology was...originally nothing other than a historical schema of nature" (1:472; see also Chapter 2.6). Thus the conceptual shift from mythology as schema to mythology as symbol is illuminating. Schema, allegory, and symbol are the three modes of presentation made possible by the imagination: schematism is the intuition of the particular in the universal, allegory is the intuition of the universal in the particular, and the symbolic is the synthesis of particular and universal in the real (PA, 46/ 5: 407). So, in contrast to the "Survey," Schelling now holds that "it would be impossible to comprehend mythology...simply as a schematism of nature" ( $P A, 47 / 5: 408)$. Literally, mythology is a symbol (Sinnbild: 'sense-meaning/image') of the absolute: the gods have meaning in their being, "by simply being as they are without any reference to anything

${ }^{44}$ Marquet, Liberté et existence, 253. 
else...[they] allow the meaning itself to be dimly visible" $(P A, 49 / 5: 411)$. The presentation of absolute indifference is only possible symbolically; what is True of the gods is True of the ideas. From there, an entire set of analogies follow: just as the ideas follow from one another, so do the gods arise through a theogony of procreation ( $\$ 36)$, just as reason is neither conscious nor unconscious, nor is mythology intentional $(\S 42)$, just as reason is the indifference of freedom and nature, Greek mythology brings "nature itself back to us in art" $(\S 42, P A, 51 / 5: 415)$.

Because Greek mythology presents a totality of symbols of the ideas, Schelling held that the Greeks also possessed the highest manifestations of art: they were exemplary in both sculpture and tragedy, the former presenting the indifference of the real, and the latter the indifference of the ideal. In tragedy, as the presentation of indifference, freedom and necessity are viewed as they are in reason: "That this guilty person, who after all only succumbed to the superior power of fate, is nevertheless punished, was necessary precisely in order to show the triumph of freedom, and was the recognition of freedom and the honor due to it" (PA, 253/5: 696-697; cf. Letters, 193/1: 336-337). Schelling himself reminds us that this was the account given already in the Letters, but this elides a crucial difference. There, the measure of tragedy was practical philosophy and the demand that freedom be the highest principle of praxis. Because the hero of tragedy eventually succumbed to fate was the honor due freedom, but it could not provide a system of ethics for mere mortals, only a race of titans. Thus, in conclusion, Schelling states that Greek tragedy could not reconcile freedom and necessity.

In the system of identity, however, tragedy is the highest symbol of the absolute indifference of freedom and necessity. Tragedy, in its performance, literally enacts (produces 
or presents: darstellen) the identity of freedom and necessity. Schelling rejects Aristotle's thesis that misfortune befalls the tragic hero due to some error in his or her actions. Instead, Schelling argues that the highest possible misfortune is to "to become guilty without genuine guilt" through fate $(P A, 252 / 5: 694-695)$. Yet tragedy would not be adequate to its idea if this was the only necessary condition: fate must also be subordinated to the hero's "sublime character" (erhabenen Gesinnung), which is realized in the voluntary acceptance of being punished for an involuntary transgression $(P A, 254 / 5: 698)$. It is no coincidence that Oedipus is a central figure in Schelling's account, because despite his "unmerited guilt" he pursues the consequences of fate at a cost to his own dignity and life. Finally, after a predominance of fate, and then free action, tragedy also requires an inner reconciliation to complete it as a work. So, as in Oedipus at Colonus, Sophocles brings about the "inner reconciliation" of harmony, an equilibrium between freedom and fate, when Oedipus disappears from the eyes of mortals ( $P A, 258 / 5: 703-704)$. Taken in Schelling's strict sense, the essence of tragedy is the symbol of the restoration of indifference.

Thus Peter Szondi is right to claim that with Schelling there is a shift from a poetics of tragedy, inaugurated by Aristotle, to a philosophy of tragedy. In a poetics, one takes as an object the elements of successful tragedy, while with Schelling, one explicates the idea of tragedy. ${ }^{45}$ For Schelling, Aristotle views tragedy from the mimetic play of pity and fear without uncovering the cause, which is the idea. It is not the combination of poetic elements but the realization of the identity of freedom and fate that makes tragedy sublime. If tragedy reaches these sublime heights, it is because it presents the perfected image of the absolute in

\footnotetext{
${ }^{45}$ Peter Szondi, An Essay on the Tragic. Trans. Paul Fleming (Stanford: Stanford University Press, 2002$), 1$.
} 
a public and ritual event, ${ }^{46}$ wherein the identity of freedom and necessity is embodied (like sculpture, he says) in the finite.

Yet Schelling does not draw, from this account, nostalgic consequences. Instead, he interprets this totality of Greek mythology and its embodiment in drama as a harbinger of the future. Thus we can see why he finds mythology attractive: the harmony of the Greek world (or, better, the harmony that Schelling ascribes to the Greek world, by overlooking any of its social divisions and conflicts) points toward the possibility of the future reconciliation of all the divisions that mark modernity. Like the System of Transcendental Idealism, Schelling writes that mythology is the "primal matter from which all else issued, the ocean, to use an image the ancients themselves used, from which all rivers flow out and to which all flow back" $(P A, 52 / 5: 416)$. This reconciliation he calls providence. ${ }^{47}$ The shift from the nature (the real) to the ideal (freedom) presents an 'odyssey of human consciousness that unfolds according to a schema analogous to that of the metamorphoses of art. ${ }^{, 48}$ This history of human consciousness separates out its freedom from nature in Christianity along with the promise of a return to the harmony of the mythology of the future. Hence antiquity becomes a part of an eschatology, wherein to account for the history of modern art, Schelling historicizes all art, without reconciling this history with the ground of the system, the absolute substance. As we will see, where Greek antiquity possessed a unity of mythology

\footnotetext{
${ }^{46}$ Schelling is not alone in grasping the public character of theatre, which has also drawn the attention of Nietzsche, Sartre, and more recently, Alain Badiou. Badiou is not only a philosopher and playwright, but also discusses the mise en scene of theatrical-ideas. See his Handbook of Inaesthetics. Trans. Alberto Toscano. (Stanford: Stanford University Press, 2005), 72-77.

${ }^{47}$ Schelling states that fate and providence are also identical within the absolute: fate is a form of providence intuited within the real while providence is also fate, but intuited within the ideal. Fate is natural, providence historical $(P A, 61 / 5: 428)$. See also the Eighth Chapter of On University Studies Trans. E.S. Morgan (Athens, Ohio: Ohio University Press, 1966), 82-91/5: 286-295.

${ }^{48}$ Marquet, Liberté et existence, 266.
} 
and art, modern art is oriented toward the demand to create a new mythology. This new mythology, I will argue, is neither Greek, nor Christian, but a reconciliation of the two.

Christianity arises in the decline of antiquity, what Schelling calls the fall of the natural world, and it is distinguished from Greek mythology by the predominance of the idea and a spirit of universality. ${ }^{49}$ The antithesis is clearer when Schelling argues that for the Greeks the universe is intuited as nature, while for Christianity the universe is intuited as a moral world, the Kingdom of God $(P A, 61 / 5: 430)$. When Greek mythology was grounded in the informing of the infinite into the finite form of the gods, Christianity is grounded on informing the finite into an allegory of the infinite.

As we have seen, the intuition of the universal in the particular is allegorical, or, the particular signifies the universal. Hence the figure of Christ in Christianity: through Christ's embodiment of the infinite, his sacrifice and his resurrection, the finite is nullified and overcome. Christ simultaneously closes the world of the ancient gods and marks the transcendence of the ideal world over the real world, reversing the relationship between the natural world and the ideal world. This reversal and revelation opens a universal history by closing the particularity and finitude of antiquity and bringing forth the anticipation of future redemption. No longer is the finite the symbol of the infinite:

In Christ it is rather the finite that is symbolized by the infinite than the latter by the former. Christ returns to the supersensible world and promises not himself but rather the spirit, and not the principle that will enter into and abide in the finite but the ideal principle that is to lead all of the finite into and to the infinite $(P A, 64 / 5: 432)$.

\footnotetext{
${ }^{49}$ It should be noted that Schelling recognizes other mythological systems from the 'Orient' only to dismiss them or to show how it is "necessary that the Oriental ideas [are] planted in Occidental soil" $(P A, 59 / 5: 5$ : 426/427). For a concise account of Schelling's attitudes toward Indian literature and religion, see Jean W. Sedlar, India in the Mind of Germany (Washington, D.C.: University Press of America, 1982), 41-46.
} 
Thus Christ cannot be interpreted as a symbol in his being, he essentially lacks the finitude of the symbolic, unlike the Greek gods who contained their meaning in their being. Instead Christian symbolism is embodied entirely in action and the church. The liturgy of the church gave body to Christian doctrine, making its "cult a living work of art, a kind of spiritual drama in which each member had a part" $(P A, 65 / 5: 434)$.

However, Schelling struggles with the relationship between mythology, the Catholic Church and the "historical necessity" of the Protestant Church. He argues that only Catholicism "lived in a mythological world" $(P A, 72 / 5: 443)$ but speaks of this mythology in the past tense. While his discussion of Protestantism is curt, he does acknowledge that its institution gave new impetus to free thought and invention. It is notable that Schelling mentions that this new impetus took up the "spirit of classical antiquity" which implies an impulse to the natural or real principle, although it did not develop. What did develop was sectarianism. Whither the destiny of Protestantism, though, Schelling's interpretation still implies, albeit politely, that its emergence has its ground in the decline of the mythological potential of Catholicism. The division of Christianity through the Reformation forecloses on mythology, and if this is the case, any use of mythology degenerates into formality ( $P A$, 73/5: 444).

It appears then, that modernity leaves Schelling nostalgic, that he finds, by the measure of the possibilities offered for mythology, the ancient world to be superior to the modern. This image of Schelling's thought, however, does not take full account of the philosophy of art as a totality. I cannot agree with Joseph P. Lawrence's verdict that in the "Christian era it becomes progressively clearer that art cannot serve as an adequate medium 
for the absolute. ${ }^{, 50}$ Instead, I think Schelling's entire argument is that 'in the modern era it becomes progressively clearer that Christian art cannot serve as an adequate medium for the absolute' because the one-sided development of an ideal mythology withdraws from nature and renders it a mystery. So Schelling interprets the transformations of modernity as a spiritual or religious crisis. All the conflicts of the modern world arise from Christianity. ${ }^{51}$ Schelling is advocating a renewal of a sense of public liturgy beyond either Catholicism, Protestantism or the Deism of the Enlightenment. ${ }^{52}$ What is required to resolve this crisis is the reconciliation between the ideal and real principles, or, in mythological terms, the redivinization of nature and the naturalization of the gods. To this demand, Schelling sets out a prescriptive diagnosis for the future of art. First, Schelling argues, it is imperative that the individual artist creates from his or her individuality a partial mythology, a work of art which, second, reconciles all the aspects of the artist's era: its history, science and poetry.

As Schelling states, the necessary law of modern poesy is "that the individual form that part of the world revealed to him into a whole, and from the subject matter of his own age, its history and its science create his own mythology" $(P A, 240 / 5$ : 154 ; see also $P A, 73 / 5$ : 444). In this regard, the individual artist (or poet) must now create what was once the material of the collectivity. In the face of change and transformation, the task of the poet is to create enduring forms out of the fragmentary nature of modernity, to create totality $e x$ nihilo. Thus the law of modern poesy requires originality in the combination of the various elements of poetry, history and science to craft a singular mythology. In a sense, Christianity already provides the form of this law by showing the finite to be transitory, by creating from

\footnotetext{
${ }^{50}$ Joseph P. Lawrence. "Art and Philosophy in Schelling," in The Owl of Minerva 20 (1988), 13.

${ }^{51}$ This is precisely what Marx would call a religious mystification of material production. The idea of spiritual crisis has a long history because it is one answer to the tendency inherent to capitalism to produce material crises through the constant revolutionizing of the means of production.

${ }^{52}$ See also Williamson, The Longing for Myth in Germany, 60-71.
} 
the finite an allegory of the totality. Yet the fragments must take on a symbolic quality within the totality.

One embodiment of modern poesy in this regard is the novel, which absorbs the various materials in an age to create a totality. Formally, the novel transforms the fragmentary, through narration, into a totality; it forms from the indifference of prose its own internal rhythm. The novel, Schelling claims, "should be a mirror of the world, or at least of the age, and thus become a partial mythology" $(P A, 232 / 5: 676) .{ }^{53}$ All the aspects of the age can be utilized to craft a unified narrative, where out of fragments the absolute is portrayed. The center of the novel is the protagonist, with whom the author should not personally identify; instead the protagonist should function symbolically within the whole. I do not think it is too radical to suggest that Schelling would argue that the protagonist is only a fragment, and thus imperfection and irony become especially powerful devices. So, the limited perspective of the characters presents in an ironic and unconscious manner the objective situation of the novel. Goethe's Wilhelm Meister is Schelling's exemplar:

The protagonist promises much and many things; he appears destined to be an artist, but he loses this false conception, since through the four volumes he appears or is treated continually not as a master, as his name implies, but as a pupil ... The background reveals itself toward the end and displays an infinite perspective on all the wisdom of life behind a kind of illusory game ... Only the mystery of the apprenticeship itself articulates this wisdom: namely, only he who has recognized his own destiny is a master $(P A, 235-236 / 5: 681)$.

No doubt Schelling praises Wilhelm Meister, in its idea, for its similarity to drama, in which freedom and destiny appear in their identity.

Second, the mythology to come requires the synthesis of history and nature. We can see what Schelling considers his specific contribution to the future: modern mythology

\footnotetext{
${ }^{53}$ Of course, that is easy for Schelling to say, since he claims that "there have been only two novels, namely, Don Quixote by Cervantes and Wilhelm Meister" (PA, 234/5: 679).
} 
requires a speculative physics. The more modernity has turned to the ideal, the more nature has withdrawn in mystery. While originality and freedom is central to modern poesy, they do not suffice to create a new mythology. Freedom, and its manifestation in history, must be reconciled with the real principle of nature. As Schelling states, "in the philosophy of nature, as it has been developed from the idealistic principle, the first, distant foundation has been laid for that future symbolism and mythology that will be created not by an individual but rather by the entire age" $(P A, 76 / 5: 449)$. The nature-philosopher awaits the gods of the new physics. ${ }^{54}$ An audacious and naïve demand, but recall what, exactly, Schelling expected: 1) that nature-philosophy, properly developed, would be able to reveal the totality of nature as organic; 2) that humanity would be shown to be the highest expression of reason within the natural world (and not above it); and 3) that all of nature would be organized according to an ascending order of potencies.

These demands are a great responsibility for the poet, one that seems beyond the modern world. However, Schelling finds that one poet has accomplished this mythology, and that work began the modern artistic era. This is Dante's Divine Comedy, which is so singular, as Schelling admits, that it requires its own theory, which places it in a "genre in and for itself." ${ }^{55}$ Even if the Divine Comedy is hindered by its Ptolemaic science, Dante still remains the model of modern poesy. He takes up all the elements of his age, science, history, religion, and creates a totality that is both allegorical and symbolic: the characters and their

\footnotetext{
${ }^{54}$ Compare to Schelling's programmatic statement at the end of the 1803 edition of the Ideas for a Philosophy of Nature: "The ideal world presses mightily toward the light, but it is still held back by the fact that nature has withdrawn as a mystery. The very secrets which the ideal harbors cannot truly become objective save in proclaiming the mystery of nature. The still-unknown deities, which the ideal world is preparing, cannot emerge as such until they can seize possession of nature. After all finite forms have been struck down, there is nothing more in the wide world to unite mankind but collective intuition, it can only be the contemplation of absolute identity in the fullest objective totality that afresh, and in the final development to religion, unites them forever" (Ideas, 54-55/2: 72-73).

${ }^{55}$ I do not lay any claim to being a scholar of Dante (nor Goethe for that matter); hence what follows is only a gloss on Schelling's interpretation.
} 
actions can be read allegorically (for instance, Beatrice is an allegory of theology), at the same time that each of the elements form a symbolic totality, in which the individual parts unveil their own inner meaning. Dante freely created a mythology, because no living mythology could provide the content. Instead, the Divine Comedy draws on all aspects of its age. The main structure even reflects the "three great objects of science and culture": the Inferno presents and image of the "eternal night" of nature, Purgatorio follows the historical process of purification and transition toward the infinite, and Paradiso, anticipates the absolute as reconciled and truly within the center" ( $P A, 243 / 5: 157-158)$.

Thus Dante's work shows that mythological creation is still possible in modernity. Schelling claims that "it is prophetic and prototypical for the entirety of modern poesy" ( $P A$, 247/5: 163). Where Christ signified the closure of the ancient world and the beginning of a universal history, Dante's Divine Comedy similarly constituted the poetic rupture between ancient and modern poesy. But that Dante's work is a thing of the past, "cloaked with the sacredness of antiquity" ( $P A, 239 / 5: 152)$ seems to correspond to Schelling's use of the past tense to describe the mythology of Catholicism. This would only lend further evidence to my claim that modern mythology cannot be specifically Christian, but must reconcile ancient and modern poesy. No doubt Schelling saw Goethe's Faust as an exemplar, even if he only had access to the fragment.

Yet, were it to be Faust, there is one more element required for the new mythology, and it is that the work of art must have a public or communal character. Drama certainly qualifies, because the works of theatre present the embodiment of the idea on stage; drama lives its life as public life (along with music, song, dance, and what Schelling calls the "caricature" of ancient drama, opera). The reconciliation of ancient and modern poesy aims, 
for Schelling, precisely to revitalize and renew public life. The religious resources of the modern age are not enough, so it is through renewing the spirit of antiquity that a new public life can be organized. As Schelling concludes:

Wherever public life disappears, instead of that real, external drama in which, in all its forms, an entire people participates as a political or moral totality, only an inward, ideal drama can unite the people. This ideal drama is the worship service, the only kind of truly public action that has remained for the contemporary age, and even so only in an extremely diminished and reduced form $(P A, 280 / 5: 736)$.

As we will see in Chapter 5.4, in the Würzburg Lectures Schelling takes up the political and public aspect of mythology in a philosophy of the state.

\subsection{Substance or History?}

I have argued in this chapter, contrary to a common image of Schelling's intellectual development, that identity-philosophy does not relegate the philosophy of art to a secondary status within the system. Instead, art-philosophy retains almost all of its structural importance found in the System of Transcendental Idealism. What has changed is Schelling's metaphysical framework: where the activity of the self once grounded artistic production, now Schelling proposes a theory of potencies, and even in this shift, the 'power' (Kraft) that produces art is the same: that of imagination. It was in researching these similarities and continuities within the philosophy of art that I gradually began to recognize another set of similarities and problems shared by identity-philosophy and Schelling's work after 1807. The distinctions and differences constructed in the Philosophy of Art are collapsed in Über das Verhältnis der bildenden Künste zu der Natur of 1807. I have argued that these distinctions, especially between the first principle of identity-philosophy in general and the historical construction of the gods resulted in a contradiction within the system: if 
Schelling retained the Spinozist first principle of an impersonal absolute, he would lose the abundance of the historical construction of the gods (they would be merely illusory appearances, which contradicts the infinite side of the gods, and the Christian God), and to maintain the historical construction of the gods as actual, Schelling would need to abandon the eternal immutable substance of the absolute. For the remainder of the period of identityphilosophy, Schelling upheld the Spinozist core of the system, but by 1807, in his address in Munich, he discarded the immutable form of Spinozist substance in order to develop an account of the historical revelation of the absolute in both art and nature. 


\section{Chapter Five}

\section{From Art and Nature to Revelation and Freedom}

Natur und Kunst sie scheinen sich zu fliehen

Und haben sich, eh man es denkt, gefunden;

Der Widerwille ist auch mir verschwunden,

Und beide scheinen gleich mich anzuziehen.

-Goethe, "Natur und Kunst""

\subsection{The Moment in Munich}

The focus of this final chapter is Schelling's Über das Verhältnis der bildenden Künste zu der Natur, ${ }^{2}$ which was delivered at the Akademie der Wissenschaften in Munich on the occasion of the King's Name-day on October 12, 1807, and later, included in Schelling's Philosophischen Schriften with his Philosophical Investigations into the Essence of Human Freedom. ${ }^{3}$ While today, the Münchener Rede has received little attention, it was, according to Xavier Tilliette, something of an event (over five hundred people, including Crown Prince Ludwig, were in attendance), earning the praise and scorn of many of Schelling's friends and erstwhile colleagues in German intelligentsia. ${ }^{4}$ As Caroline Schlegel-Schelling describes the

\footnotetext{
${ }^{1}$ Berliner Ausgabe, 121; A translation by Michael Hamburger is in Selected Poems. Ed. Christopher Middleton (Boston: Suhrkamp, 1983), 164-165: "Nature, it seems, must always clash with Art/And yet, before we know it, both are one/ I too have learned: Their enmity is none/ Since each compels me, and in equal part."

${ }^{2}$ Abbreviated in the following as the Münchener Rede.

${ }^{3}$ The Philosophischen Schriften also included Vom Ich, the Letters and the Allgemeine Uebersicht der neuesten philosophischen Literatur, the latter of which was edited (omitting the final section from 1798 that I discussed in Chapter 2) and renamed the Abhandlungen zur Erläuterung des Idealismus der Wissenschaftslehre.

${ }^{4}$ Between the letters collected by Tilliette and Lucia Sziborsky, those in the know included Goethe, the brothers Schlegel, Niethammer, Johann Wilhelm Ritter, Henrik Steffens and Friedrich Tieck. See Xavier Tilliette, "Schelling, l'art et les artistes," in Schelling, Textes esthétiques. Trans. Alain Pernet (Paris: Editions
} 
event to Luise Gotter, "Schelling spoke with a dignity, virility and enthusiasm that friend and foe were overcome...several weeks later and in the court and city the only talk (Rede) is Schelling's talk (Rede). ${ }^{5}$ After receiving a copy from Niethammer, Hegel writes, sarcastically, that: "Just as the ocean produces grain, the Arabian desert wine, and Gotthard oranges, so Munich flourishes with pentameters and hexameters...as also with aestheticphilosophical addresses." Jacobi, who presided over the address, was appalled, although he saved his scorn for his epistolary exchanges.

Although it received much attention in its time, the Münchener Rede is relatively neglected today in Schelling scholarship, perhaps because it is his last significant work on the philosophy of art before his 'theological turn' toward the philosophy of freedom.' As I will argue, this neglect is unwarranted because the Münchener Rede is an important point of transition between the problems that plagued identity-philosophy and those that drove the philosophy of freedom.

As I argued in Chapter Four, Schelling's development of the philosophy of art resulted in a contradiction between the deductions of its rational formalism and the historical construction of art's mythological content. As much as Schelling tried to cover over this

Klincksieck, 1978), xxxi-xxxiii; Lucia Sziborsky, ed. "Aus zeitgenössischen Briefen," in Über das Verhältmis der bildenden Künste zu der Natur (Hamburg: Felix Meiner Verlag, 1983), 69-79.

${ }^{5}$ Sziborsky, "Aus zeitgenössischen Briefen," 69-70. The letter is dated October 12, 1807, although this seems to be in error.

${ }^{6}$ To Niethammer, dated November 1807 (number 108), in Hegel, The Letters. Trans. Clark Butler and Christiane Seiler, with commentary by Clark Butler (Bloomington: Indiana University Press, 1984), 149.

${ }^{7}$ Recent texts that develop the concerns of the Münchener Rede include Marquet, Jean-François. Liberté et existence. Second Edition (Paris: Les Éditions du Cerf, 2006), 354-363; "Schelling et le destin de l'art," in Actualité de Schelling. Ed. G. Planty-Bonjour (Paris: Vrin, 1979), 75-88; Dieter Jähnig, Schelling: Die Kunst in der Philosophie, Vol. 2 (Pfullingen: Neske, 1969), 66-70 130-137, 259; Peter L. Oesterreich, "Die Gewalt der Schönheit," in Schellings Weg zur Freiheitsschrift: Legende und Wirklichkeit. Ed. Hans M. Baumgartner, Wilhelm G. Jacobs (Stuttgart-Bad Cannstatt: Frommann Holzboog, 1996), 95-109; and Joseph P. Lawrence, "Art and Philosophy in Schelling," in The Owl of Minerva 20 (1988), 15-19. 
contradiction with the formal structures of the system of identity (such as dividing between the real, ideal and indifference), the more his account, as it dealt with particular details, exceeded these structures. This problem is especially visible in the historicism implied in the transition from Greek antiquity to Christianity.

In the Münchener Rede, these formal structures of identity-philosophy- that is, its distinctions between philosophy in general, the historical construction of the content of art and the construction of the particular forms of art- have been abandoned. What we find in the Münchener Rede, by contrast, is a kind of unified philosophy of nature, history and ethos of art. It is remarkable that the Münchener Rede is the only time that Schelling unifies the true (science), the good (history and practice) and the beautiful within an ethic of artistic production, in which art both reveals nature as it produces itself and demonstrates a moral force in its productions. ${ }^{8}$ In its relationship to nature, true art draws on the living power of nature to reveal its divine character, but also, reveals the very history of natural production itself. As Dieter Jähnig states, "What art brings forth (hervorbringt) is the bringing-forth itself." And, in the moral realm, Schelling presents an ethic of artistic production that shows how the artist presents the world morally through subordinating human passions to the realization of the beautiful or the sublime. In so doing, Schelling argues that art reveals what is divine in humanity and nature.

The first part of this chapter will disentangle this account from Schelling's allusive rhetoric of the address itself. The exegetical difficulties lie in the rhetorical structure, which

\footnotetext{
${ }^{8}$ Here Nietzsche could object that existence is only bearable as an aesthetic phenomenon and not as a moral phenomenon. One might answer that the worldview of the Münchener Rede is more melancholy than what is traditionally thought as moral, and that in subsequent texts Schelling's worldview becomes ever more tragic. In the essay Of Human Freedom, Schelling calls finitude the source of a "deep indestructible melancholy of all life" that affects even God himself $(H F, 62-63 / 7: 399)$. See Nietzsche, The Gay Science. Trans. Walter Kaufmann (New York: Vintage Books, 1974), Section 107, pp. 163-164. My criticism of Schelling's mythologization of politics is below.

9 Jähnig, Schelling: Die Kunst in der Philosophie, Vol. 2, 133.
} 
builds through allusion and repetition, the anticipation and evocation of ideas, which are then only later developed, in order to produce the emotional rhythm of the speech. In this regard, the Münchener Rede is a singular text (as his contemporaries recognized!) in Schelling's oeuvre; it is far from the dry axiomatic deductions and aphorisms of the lectures of identityphilosophy. ${ }^{10}$

If we recognize this singularity, however, we are also confronted with the question of why Schelling proceeded to abandon his philosophy of art: its rapid disappearance is, for the Schelling scholar, puzzling. Various answers have been proposed, and because they draw on different aspects of Schelling's later thought (which continued to develop for over four more decades), they are not even incompatible. In "Several Connections Between Aesthetics and Therapeutics in Nineteenth-century Philosophy," Odo Marquard proposes that Schelling's aesthetics give way to an emphasis on medicine as a technique to render the power of nature unthreatening. Marquard marks the shift from aesthetics to medicine from 1800 to 1806 , at the same time that Schelling "distanced himself from the actual project of carrying out his aesthetics, he gave medicine a significant philosophical revaluation."11 For Jean-François Marquet, art is replaced by Schelling when Christ is presented as a cosmological puissance, from 1809 onwards, but especially in the Weltalter and the later Philosophy of Mythology. ${ }^{12}$ And Dieter Jăhnig proposes, drawing on the later philosophy, that Schelling abandons the philosophy of art because of art's ineffectiveness (Wirkunglosigkeit) in history. ${ }^{13}$

\footnotetext{
${ }^{10}$ On the rhetoric of the address, see also Oesterreich, "Die Gewalt der Schonheit," 95-101.

${ }^{11}$ Odo Marquard, "Several Connections Between Aesthetics and Therapeutics in Nineteenth-Century Philosophy," in The New Schelling. Ed. Judith Norman and Alistair Welchman (New York: Continuum, 2004), 21. This is the most speculative and difficult solution to defend, since the Münchener Rede post-dates Marquard's chronology of these developments.

${ }^{12}$ Marquet, "Schelling et le destin de l'art," 87.

${ }^{13}$ Jahnig, Schelling: Die Kunst in der Philosophie, Vol. 2, 313-319. As Schelling himself says, "history shows us no example of an age that deeply divided, confused, and doubtful of itself has reconciled and healed itself
} 
In contrast to these previous answers, which draw on Schelling's later work, I sought to find a text that would specifically engage the same themes as the Münchener Rede, which would then offer a point of contrast between the philosophy of art and his philosophy of freedom. The inclusion of the Müchener Rede with the essay Of Human Freedom in the Philosophischen Schriften of 1809 presented to me an initial clue, that the philosophy of freedom which re-conceptualized freedom outside of the Kantian-Fichtean formalism of the moral law, no longer required the higher ethic of the philosophy of art. Hence, from 1809 onward, Schelling's ecstatic account of freedom took the place of artistic production. However, tracing the continuities and differences between these two texts proves both difficult and highly speculative due to the near absence of references to art in Of Human Freedom (for an exception see $H F, 75-76 / 7: 414$ ).

The Stuttgart Seminars from 1810, however, deal with both the theological and philosophical concerns of the Freiheitsschrift and the Münchener Rede. ${ }^{14}$ I will argue that one of the most important shifts in Schelling's philosophical orientation concerns his view of history: while the texts on art are oriented toward the future and a new mythology that could overcome the fragmentary nature of humanity, the Stuttgart Seminars are oriented toward the past. In his discussion of the past, Schelling argues that the Fall of humanity was a real historical event. Thus his emphasis shifts from the future 'redemption' of a new mythology to explaining how the Fall precipitated the human condition. This change in orientation transforms Schelling's conception of artistic production: where once art was the highest vocation of humanity, it is now limited to expressions of an artist's individuality or of

through poetry." In The Grounding of Positive Philosophy: The Berlin Lectures. Trans. Bruce Matthews (Albany: SUNY Press, 2007), 96/13: 12).

${ }^{14}$ Antoon Braeckman also draws connections between Schelling's philosophy of art and the Stuttgart Seminars, but omits the Münchener Rede, which hinders his argument. See "The 'Individual Universal': The Sociopolitical Meaning of the Work of Art in Schelling," Idealistic Studies, vol. 34/1, 67-83. 
longing for a lost connection to nature. In the place of artistic production, Schelling now prescribes the cultivation of freedom through a universal religious knowledge.

We will conclude by examining the political implications of the idea of a new mythology. Like many of his contemporaries, Schelling eventually turned away from revolutionary enthusiasm to either political quietism, mysticism, or some degree of conservatism. ${ }^{15}$ This shift can be traced in the gradual shift from a revolutionary and utopian vision of the new mythology to what I will call the mythologization of politics, until Schelling abandons his philosophy of art altogether. By mythologization of politics I mean the gradual conceptual unification of art, mythology and the state, in which mythology serves, or is proposed, as an ideological component of legitimating political power. However, let me be clear that the mythologization of politics is not equivalent to what Walter Benjamin calls the aestheticization of politics, in which aesthetic judgments become political judgments regarding events such as war. ${ }^{16}$ In this way, we avoid falling into the generalizations that allow Lukács, in his book The Destruction of Reason, to argue that irrationalism leads (as the subtitle indicates) "from Schelling to Hitler." ${ }^{17}$ Not only are the material factors absent, such as the level of technological development, that Benjamin takes

\footnotetext{
${ }^{15}$ For a constellation-view of these changes, see Dieter Sturma, "Politics and the New Mythology: The Turn to Late Romanticism," in The Cambridge Companion to German Idealism. Ed. Karl Ameriks (Cambridge: Cambridge University Press, 2000), 219-238 (who focuses on Schelling); Klaus Peter, "History and Moral Imperatives: The Contradictions of Political Romanticism," in The Literature of German Romanticism. Ed. Dennis F. Mahoney (Rochester, NY: Camden House, 2004), 191-208; and for an account of conservatism in Germany in the 1790s, see Frederick C. Beiser, Enlightenment, Revolution, and Romanticism (Cambridge, Mass., Harvard: 1992), 281-334.

${ }^{16}$ See Walter Benjamin, "The Work of Art in the Age of Its Technological Reproducibility" in Selected Writings: Volume 3, 1935-1938. Ed. Howard Eiland and Michael W. Jennings (Cambridge, Mass., Belknap/Harvard: 2002), 120-122.

${ }^{17}$ Georg Lukács, The Destruction of Reason. Trans. Peter Palmer (London: Merlin Press, 1980), 129-192. See Adorno's critique in "Reconciliation Under Duress," in Adorno et al. Aesthetics and Politics (London: Verso, 1977), 152: "In a highly undialectical manner, the officially licensed dialectician sweeps all the irrationalist strands of modern philosophy into the camp of reaction and Fascism. He blithely ignores the fact that, unlike academic idealism, these schools were struggling against the very same reification in both thought and life of which Lukács too was a dedicated opponent."
} 
as the material basis of the mobilization of fascist politics, but the conceptual framework is different: the aestheticization of politics is a reactionary and militaristic politics, while what I have called a mythologization of politics is closer to what Marx would call a mystification: though this political stance idealizes social relationships, that does not preclude it from being gradualist, reformist, or quietist. What is important is that it places Bildung or cultivation of peoples or publics over direct or democratic political engagement. This, however, does not excuse pernicious political concepts, such as 'organic communities or peoples' from criticism; it is meant to show the tensions and ambiguities of Schelling's political or social philosophy.

As we can see today, ideologically Schelling was close to a dangerous political stance when he envisioned an organic totality of a people who, as if they embodied a single poet, create a new mythology. Conceived under the form of the state, this idea of a people brings with it unacceptable political consequences: for instance, it can result, through political implementation, in the exclusion from political or public life those groups who are not considered part of the community; those who do not participate in the 'essence of a people or nation' are excluded or marginalized. Viewing this problem through the lens of a theory of hegemony, the stakes become clear: the a priori conception of universality as organic totality ignores or disregards the fact that the political space itself is the domain of the struggle over what the definition of universality (and political inclusion) is. That Schelling turns away from the mythologization of politics when he changes his focus toward a universal history of religion, just at the time when German politics becomes increasingly nationalistic, appears in retrospect well advised. 
It is testimony, for better or worse, to the power of art that both of Schelling's visions of art had a continued attraction long after the end of his philosophy of art. On one hand, the mythologization of politics, with art expressing the essence of a nation, had a long history in Germany, ${ }^{18}$ which culminated philosophically in Heidegger's "The Origin of the Work of Art." ${ }^{19}$ On the other hand, the revolutionary and utopian idea of art re-emerged in the avantgarde of the $20^{\text {th }}$ century and is still the focus of contemporary debates on the relationship between politics and art. ${ }^{20}$

\subsection{From the "Living Center" of Nature and Art...}

We left aside from the previous chapter, for purposes of presentation, the construction of the particular forms of art in order to present, here, the contrast between the Philosophy of Art and the Münchener Rede. In the former, Schelling follows the form of the triplicity 'realideal-indifference' throughout the construction of the arts, which, as I argued, is precisely how the historical construction of the content of art results in an antithesis between the system's formalism and history. But Schelling also presents a deduction of the particular forms of art largely reprises the formal sequence of the real-ideal-indifference, which is organized as follows ${ }^{21}$ :

\footnotetext{
${ }^{18}$ See George S. Williamson, The Longing for Myth in Germany (Chicago: University of Chicago Press, 2004).

${ }^{19}$ In Basic Writings. Ed. David Farrell Krell. (San Francisco: Harper Collins Publishing, 1993), 143-212. According to Heidegger, great art instigates history, history as "the transporting of a people into its appointed task as entry to that people's endowment." (p. 202). This should be read in the context of Heidegger's politics in the 1930s. His later work on poetry and technology turns away, through a possible self-critique, from political engagement.

${ }^{20}$ See, for example, Alain Badiou, The Century. Trans. Alberto Toscano (Cambridge: Polity Press, 2007); "Third Sketch of a Manifesto of Affirmationist Art" in Polemics. Trans. Steve Corcoran (London: Verso, 2006), 133-148; and Jacques Rancière, Malaise dans l'esthétique, Paris, Galilée, 2004.

${ }^{21}$ This is a simplified scheme of Schelling's categorizations. See also Douglas W. Stott's introduction to the Philosophy of Art, xxvii-lv; for comparison see also Tilliette's schemes of other presentations of absolute idealism in Schelling. Une philosophie en devenir. Vol. 1, 417-421.
} 
Table 5.1: The Particular Arts

$\begin{array}{lccr}\text { Real Series } & \text { Formative Art } & \text { Verbal Art } & \text { Ideal Series } \\ \text { Real } & \text { Music } & \text { Lyric Poetry } & \text { Particular } \\ \text { Ideal } & \text { Painting } & \text { Epic Poetry } & \text { Universal } \\ \text { Indifference } & \text { Plastic Arts } & \text { Drama } & \text { Indifference }\end{array}$

To show how he abandons the formal construction of art found in the Philosophy of Art, in favor of a historical production of art (or, 'bringing-forth,' hervorbringen), we will outline Schelling's construction of the plastic arts (music-painting-plastic arts) in the Philosophy of Art, focusing on the construction of music.

Music is the first in the series of the plastic (bildenden) arts. Therefore music is the real potency within the series, followed by the ideal, which is painting, and the informing of indifference, which is sculpture. As I have hoped to impress on the reader, for Schelling, the beginning is always the most difficult, and his construction of music is no exception to the rule. Instead, I have attempted to provide the most simplified outline for ease of presentation (see $P A, 107-109 / 5: 488-491) .{ }^{22}$ Music has its ground in the (speculatively) physical dynamic of sound (Klang). Sound is the absolute form of time in the world of art, while matter would be that of space. So sound and matter relate like concept and being, soul and body; sound requires external bodies to resonate, although in pure form, absolute sound does not require matter. Resonation requires the externality of other bodies, but also that they cohere to some degree. If matter is being, then sound is activity, and the point of indifference is hearing, which is the organic unity of the medium (matter) and activity (sound).

\footnotetext{
${ }^{22}$ This is also complicated by the fact that Schelling's determinations of music are sometimes incorrect; for instance, the basic definition of sound is a vibration or wave, which is formed by the oscillation (periodic displacement) of a medium such as air. Schelling's ideal deduction discusses absolute sound, and with more difficultly, its relation to magnetism. To get Schelling's account in order, I have consulted Marquet, Liberté et existence. Second Edition (Paris: Les Éditions du Cerf, 2006), 262-263 ; Herbert M. Schueller, "Schelling's Theory of the Metaphysics of Music," in The Journal of Aesthetics and Art Criticism. Vol. 15 n. 3 (1957), 461476; and Stott's "Introduction" to the $P A$. Let me remark, that as a musician, I thought it would be easier.
} 
Sound, constructed as an art form is music $(P A, 109-114 / 5: 491-499)$, which is divided between rhythm (real), modulation (ideal) and melody (indifference). ${ }^{23}$ Rhythm is the informing of multiplicity from homogeneity, which is why time is the universal form of music. However, it is not that music is given meaning by time, but that the rhythm of music organizes ("self-counts" as Schueller remarks) succession and thus gives meaning to time. Where rhythm informs quantitative difference (recall the resonances, as it were, with Schelling's deduction of individual things as quantitative differences in the Darstellung; see Chapter 4.2), modulation, the movement to higher or lower tones, is qualitative difference (modulation taken as totality, is harmony). ${ }^{24}$ When rhythm and modulation are posited as indifference, melody is constructed; melody is the succession of modulation within rhythm. Melody is the point of indifference because tonality is subordinated to rhythm, which is the most universal aspect of music. Unsurprisingly, the Greeks perfected melodic music, and modern music (contemporary with Schelling) subsumes rhythm to harmony $(P A, 112-113 / 5$ : 496-497)..$^{25}$

From music, the entire foundation of the particular arts is built in the Philosophy of Art, and an entire set of analogies is drawn: in the real series of art, rhythm is the musical element of music (and thus allegory), modulation that of painting (schematism), and melody

\footnotetext{
${ }^{23}$ In correspondence to the potencies, rhythm "qualifies music for reflection and self-consciousness, [modulation] for feeling and judgment, and [melody] for intuition and the power of imagination" $(P A, 112 / 5$ : 496).

${ }^{24}$ Harmony is referred to as the vertical relationship between tones, what Schelling refers to as their coexistence, and melody is then the horizontal relationship between tones. Schelling is correct to state that the use of cadence- "the movement toward the release of tension, toward absolute repose (to quote Rosen)"- and counterpoint (the use of dissonance to create tension), structures the modern music of his time; most melody in modern Western music up to the end of the $19^{\text {th }}$ century also followed harmonic resolution. See $P A, 114-115 / 5$ : 498-501; and Charles Rosen, Arnold Schoenberg (Princeton: Princeton University Press, 1975), 23-62, on atonality (the quotation is from p.26).

${ }^{25}$ Schueller notes that the stance that "melody is 'superior' to harmony is an assumption of the $18^{\text {th }}$ century" and that "melodic exploitation is a characteristic of 'classical' music up to Beethoven and that harmonic experimentation is characteristic of $19^{\text {th }}$ century musical composition. See "Schelling's Theory of the Metaphysics of Music," 472, n. 44; 473, n. 46.
} 
the plastic element (symbolic) ${ }^{26}(P A, 112 / 5: 496)$; and in nature-philosophy, music is the real expression of "pure movement as such"27 and the form of being of the cosmic bodies. This, of course, suggests Pythagoras, who, according to Schelling, did not "say that these movements cause music, but rather that they themselves are music;" in other words, the inner, pure, movement in the solar system needs no external medium $(P A, 116 / 5: 502)$.

By comparison, the Münchener Rede has abandoned the formal structure of identityphilosophy. The brief outline of Schelling's metaphysics of music, in all its details and analogies, shows the weight of the architectonic structure of the Philosophy of Art. It is easy to see how the Philosophy of Art can get caught up in antitheses. We have already identified one important antithesis between substance and history. Clearly the construction of the particular forms of art, such as music, proceed according to the formal structure of the system (its logical differences), and not primarily historically.

By contrast, the art-philosophy of the Münchener Rede unfolds according to a historical series. Missing are all the deductions and divisions between philosophy in general and the philosophy of art, the philosophy of history, and nature-philosophy (also missing, is music: Schelling refers now to the two plastic arts, sculpture and painting). Instead, they are all considered in a historical form: the first principle, the Wesen or 'living center,' unfolds in the realization (Verwirklichung) of nature and the presentation (Darstellung) of art (MR, 342/7: 310). In accordance with Münchener Rede, we will set out the historical account of the bringing-forth of art and nature, and then ask how Schelling conceives the first principle that grounds the essay's metaphysics.

\footnotetext{
${ }^{26}$ So, for example, architecture is "solidified or frozen (erstarrte) music" $(P A, 165 / 5: 576)$.

${ }^{27}$ This also implies, as Schueller points out, the real expression of mathematical relationships. "Schelling's Theory of the Metaphysics of Music," 470.
} 
The theoretical structure of the Münchener Rede, draws on Schelling's metaphysics of potencies, in which finite things are expressed according to an ascending series of perfection. ${ }^{28}$ Recall that in the Philosophy of Art, the same order of potencies could be found in nature, history and art. For example, Schelling states that works of art present the intellectual world in the finite world:

music is nothing other than the archetypal rhythm of nature and the universe itself, which by means of this art breaks through into the portrayed (abgebildliche) world. The complete forms that are brought forth by the plastic arts are the objectively presented archetypes of organic nature itself. The Homeric epic is identity itself as it lies at the basis of history within the absolute. Every painting discloses the intellectual world $(P A, 17 / 5: 369)$.

I chose this passage, over the others, precisely because of its reference to the plastic arts. The continuities are clear: while Schelling no longer discusses music in the Münchener Rede, sculpture still reveals the inner forms of organic nature (that is, where music was once the origin, the point of creation, of the formative arts, now sculpture is), and painting still discloses, despite a change in terminology, something like the entirety of the revealed (formerly called 'intellectual') world. The similarities go beyond the particular arts. The ascending order of potencies or powers reappears in the Münchener Rede:

Nature, in its broader sphere, always presents the higher simultaneously with its lower: creating the divine in man, it produces in all other products the mere material and ground thereof, so that essence as such shall appear in contrast to it. Indeed, in the higher world of man the great mass once more becomes the basis to which the divine, that has preserved its purity in the few, is manifested in lawgiving, dominion and the founding of religious faiths. Hence, where art operates with more of the manifoldness of nature it [art] may and must exhibit, alongside the highest measure of beauty, its groundwork and, as it were, the material of the latter in its own forms (Bildungen) (MR, 339/7: 308).

While the potencies recur in nature, humanity and art, to properly understand the difference between the Münchener Rede and Schelling's previous philosophy we need to place the

\footnotetext{
${ }^{28}$ Note, however, that where the Philosophy of Art uses Potenz the Münchener Rede uses Kraft.
} 
emphasis on creation: it is not just that these formal structures reoccur, but that the same Urkraft (primal power) is expressed in all finite forms in ascending potencies. ${ }^{29}$ As JeanFrançois Marquet points out, the Münchener Rede is the first place where "the origin of the world will be envisaged," in the work of Schelling, "as creation." Each successive revelation raises the previous potency to a higher power. The task of the Münchener Rede is to show how these potencies are brought forth.

The problem, however, is the origin. We will discuss it twice, first as it takes place in nature and art, and then as it pertains to the absolute as first principle of the essay's metaphysics, a philosophy of freedom in nuce. The difficulty of the beginning arises from the modern alienation from nature. Recall the diagnosis found in the Philosophy of Art and the second edition of the Ideas for a Philosophy of Nature: the more the ideal world is perfected, the more nature withdraws as mystery (See Chapter 4.4; and $P A, 76 / 5: 449$; Ideas, 54-55/2: 72-73). As the cited passages show, Schelling understood nature-philosophy as a contribution to unraveling this mystery, to decode the "poem lying pent in a mysterious and wonderful script" (ST, 232/3: 628). The Münchener Rede is Schelling's first attempt to discover the Urkraft at the basis of both nature and art, which is why he begins by rejecting the usual debate of whether art should imitate nature or recreate it as an ideal. All previous answers to this false dilemma have not grasped the living center of nature; they only see nature as either quantity of individual objects, a container or place for these objects, or as the source of goods to be exploited (MR, 325/7: 293). ${ }^{30}$ In order to reveal nature as living,

\footnotetext{
${ }^{29}$ Marquet, Liberté et existence, 343.

${ }^{30}$ This passage seems to indicate Schelling's influence on Heidegger's development of his critique of technology. See Schelling's Treatise on the Essence of Human Freedom. Trans. Joan Stambaugh (Athens, Ohio: Ohio University Press, 1985), 137-139.
} 
Schelling argues, all these interpretations must be rejected. ${ }^{31}$ The essence of nature must be seen as the common ground of living nature, humanity and the divine power of art. As difference expressions of a common power, or Urkraft, we should expect each stage of the realization of this creative source to be repeated in nature, humanity and art.

So to begin, in nature, as in art, essence strives for realization and presentation, which is brought forth initially as form. Nature comes forth from out of chaos and the formless in order to appear in the individual, the latter of which is only possible through limitation and opposition. As Schelling states, "without bounds the boundless could not be manifested [and] if there were no harshness, mildness could not exist" (MR, 342/7: 310). In contrast to the 'labor of the negative' found in that famous book of 1807, written by one of Schelling's erstwhile comrades, limitation is not negation, but an affirmation of a higher potency; the ability to take on self-limitation is how the individual "appears as truly meaningful force (Kraft)," through limitation an individual comes to subsist within the Urkraft of nature. If one is tempted to ask 'why the absolute even bothers,' Schelling has an answer: essence takes on limitation in creation, because in its origins, its highest and divine power only lies dormant or unfulfilled. Thus the historical series is a necessary selfrevelation (what necessary means in this context, will only be explained later, in the Stuttgart Seminars). The struggle of the essence of nature to obtain the fullness of form through limitation is accomplished first in what Schelling calls the severity of form. In its initial formation, the individual is singular, isolated and inaccessible. But where the bringing forth of form is the beginning, Schelling argues that the beginning must be elevated within

\footnotetext{
${ }^{31}$ See Lucia Sziborsky, "Schelling und die Münchener Akademie der bildenden Künste" in Welt und Wirkung von Hegels Ästhetik. Ed. Annemarie Gethmann-Siefert and Otto Pöggeler (Bonn: Bouvier Verlag Herbert Grundmann, 1986) 41. Sziborsky notes that, for Schelling, the artist should imitate nature as production (natura naturans) and not nature as object (natura naturata).
} 
nature, just as it is in mankind and the divine images of art. Like the first stage of revealed nature, sculpture began in the most severe, the "goddess Athena [was] the only and only muse of plastic art." Yet nature must be elevated from form towards beauty. Concerning sculpture:

In depicting the most perfect or divine natures it was not merely necessary for the fullness of forms, of which the human nature as a whole is capable, to become united: this union must also be of the kind that we can visualize in the universe itself, namely one in which the lower forms, or those related to lesser qualities, were subsumed under higher ones and finally under one highest form, in which, to be sure, they were all mutually extinguished as particular forms, but endured in their essence and energy (Kraft) $(M R, 337-338 / 7$ : 306307).

To show how the forms are elevated toward their essence, Schelling moves from this initial revelation of nature to an anthropology of the soul, which stands as the human link between the divine and nature, and then he argues that this sequence recurs in art. The conceptual series of this progressive revelation- a kind of anthropology and theology of artistic creation-proceeds from the Urkraft of nature, to the characteristic of grace (Anmut) in the equipoise of body and soul, which itself is based on divine love. This anthropology of the soul anticipates the accounts of human freedom found later in the essay Of Human Freedom and the Stuttgart Seminars, although here it is presented as the ethos of art, which has a natural and moral force.

The elevation of nature from the severity of form takes place through the soul, and the activity, as it were, of grace (Anmut). Through grace form is consummated and overcome, the spirit that laid dormant in nature is revealed through the soul. Natural beings begin to reveal a gentleness and perfection, or in terms from Schelling's earlier naturephilosophy, the organism reaches a point of indifference between its being and activity: the "spirit of nature (Naturgeist) becomes free from its bonds and feels its kinship with the soul" 
$(M R, 342 / 7: 311)$. This kinship is possible through grace. While not yet the soul in its divine essence, which can only be actualized in humanity, it is a natural soul (Naturseele) or sensuous grace: "soul and body are in perfect concord; the body is form, grace is the soul;" in art sensuous grace is realized in the image of pure beauty, which is presented by the sculpture of Aphrodite, the goddess of love (MR, 343/7: 311).

That the soul emerges in nature as grace show that these concepts are not opposed (they only appear as opposed), but, to use Schelling's terms, the ground of nature is elevated to a higher power; nature is the medium of the soul's revelation. At this point, the Münchener Rede takes an anthropological turn: the remainder of the essay is dedicated to showing how the powers of nature drive artistic creation through their activity within the soul. Where the soul is active as a potential of nature, it is actual in human being; its revelation is an elevation of human being above the principle of individuality (which is already found in nature itself), grounding human being in a higher principle. In fact, the principle, which is divine love, is the opposite of individuality:

In man alone, as in the center, does the soul make its appearance, without which the world, like nature, would be without the sun.

Thus, in man, the soul is not the principle of individuality, but that by which he raises himself above all egoism (Selbstheit), by which he becomes capable of self-sacrifice, unselfish love and, the most exalted of all, of the contemplation and cognizance of the essence of things, and, precisely thereby, of art (MR, 343/7: 311-312).

However, if the soul is revealed unconsciously in nature, it must be consciously realized by the artist. One would think, from the apparently idyllic portrait of human personality as the equipoise of body and soul through the contemplation of art and the essence of things, that the artist's task were uncomplicated, but the more tragic vision found in Of Human Freedom and the Stuttgart Seminars looms in the background. The precursor of the 'natural' or 'dark' 
principle of human being found in the latter essays appears in the Münchener Rede as the passions.

Yet we gain no insight into why the passions are introduced in the Münchener Rede by pointing out the continuities with later texts. We must also ask if the passions reveal any continuity between the Münchener Rede and Schelling's previous presentations of the philosophy of art. In the previous texts artistic activity was the highest expression of the absolute within the real because art overcame the separation of freedom and necessity, and the ideal and the real, through artistic production. The result was the conscious reestablishment of identity in the finite world. Despite the change in terminology, the passions play the role of the disruption of unity (where, previously, this was often cast in terms of consciousness necessarily arising through the separation of freedom and nature). They are, however, not a wholly negative force in themselves, because "living unity can show itself in action and activity only as the result of the forces composing it being incited to rebellion by some cause or other and departing from their equilibrium" ( $M R, 341 / 7$ : 309310). Artistic production brings forth in itself an ethic of beauty.

The goal of the artist is to moderate the passions through the realization of beauty, but Schelling points out that this act of moderation is a positive, and not a negative, force. Thus beauty moderates the passions by the higher force of beauty, or, in the case of tragedy, the sublime. In the case of beauty, "the true requirement is to oppose passion by positive force. For just as virtue does not consist in the absence of passions, but in the power of the spirit over them, so beauty is not safeguarded by their removal or reduction but by the power of beauty over them" $(M R, 341 / 7: 310)$. The task of the artist is to show this conflict of the passions and soul in the plastic arts without letting their opposition destroy the proportion of 
beauty. However, this account can only be completed by showing how the soul reestablishes its equilibrium through the power of the sublime. That Schelling cannot manage to avoid a reference to tragedy (or, for that matter, Homer) in a text on the plastic arts is somewhat ironic, but this supplemental inclusion of Greek tragedy brings with it explanatory power regarding the unfolding of his artistic sequences. For, Schelling argues, the greatest power that can struggle against the calm of the soul is not the "inferior natural spirits" but rather the insurrection of the spirit itself. The tragic hero again enters the philosophical stage: this greatest insurrection occurs when the protagonist falls into 'guiltless error': "when unbearable pain, or even madness ordained by punitive gods takes away consciousness and the power of thought, [grace] still stands beside the suffering figure as a protective daemon and sees to it that he does nothing inept, nothing contrary to humanity, but that when he falls he at least falls as a pure and undefiled victim" (MR, 345/7:313).

As we saw in Chapter 4.4 , the truly sublime and ethical protagonist of tragedy endures fate with magnanimity, which Schelling now incorporates into the metaphysics of the Münchener Rede: the truly sublime and mortal act is to face and accept annihilation over breaking the bond of the soul and divine love. This ethical act chooses the sublime over evil. As Schelling writes, in a cryptic passage: no "external power can do more than take away external goods, it cannot reach the soul; it can tear apart a finite link, but not dissolve the eternal bond of a truly divine love" ( $M R, 345 / 7: 314)$. Thus while the external power of fate cannot dissolve this bond, the question remains, what can? I think it is possible to answer this question with reference to the Stuttgart Seminars. There, Schelling argues that evil is neither a privation nor a feature of physical finitude, which is a stance that breaks with the 
modern philosophical tradition. ${ }^{32}$ According to Schelling, evil is the inversion of the two principles (light and dark) through spirit itself. This inversion is possible because spirit can revolt against the divine essence of the soul. Evil is the self-willing of a human actor to turn this elevation above nature into a "positive disharmony": the elevation of the dark ground above the true cause of human freedom, that of eternal love $(S P, 232 / 7: 468$; see also $H F$, 34/7: 365). Through what is divine, a human agent- like any number of Sade's villainswills evil and unleashes a destructive will against creation itself.

Thus we can complete Schelling's account: no external power can break the bond of love, only an inward power can; it is precisely the grace of the acceptance of fate instead of acting contrary to virtue (which is evil) that gives such a sublime power to tragedy. The revelation of divine love (although still under the form of fate) leads to the final exemplar in the series of sculpture, which is presented in the figure of the goddess Niobe. The Florentine Niobe (which is a replica of an antique work) moderates the horror that has befallen her through beauty; according to Schelling, after all the cruelty endured- as Apollo and Artemis slaughter her fourteen children- "through grief, fear and indignation there radiates, like a divine light, everlasting love " $M R, 346 / 7: 314)$. Thus in the series 'Athena-Aphrodite-Niobe' sculpture progresses, like nature itself, from severe form through sensuous grace to their unity in the equipoise between the body and soul. ${ }^{33}$ Although the final figure in the series, Niobe, reveals everlasting love, Schelling holds that sculpture, since it "presents its ideas by corporeal things, consists in the perfect equipoise between soul and matter" $(M R, 347-348 / 7$ : 316). It is painting that can bring forth truly divine love.

\footnotetext{
${ }^{32}$ A reader would not gather this by reading Susan Neiman's Evil in Modern Thought (Princeton: Princeton University Press, 2002). Although she makes three references to Schelling (pages 62, 96, 260), she never lets on that he wrote anything about the problem of evil.

${ }^{33}$ Compare to the $P A, 187-192 / 5: 609-617$.
} 
Unlike sculpture, painting can exhibit both the suffering and divine power of the soul, and can present the whole of the striving of essence beyond the embodied individual. ${ }^{34}$ The medium of painting expresses its subject matter in images, and not as individual objects like sculpture: through the techniques of chiaroscuro and the use of color painting could be considered a more spiritual medium. Painting, in contrast to the equipoise of sculpture, may "reduce the characteristics of force and activity to the advantage of the soul, whereby it appears that man became more receptive...to higher influences" (MR, 349/7: 317). As it leads to the basis, through the portrayal of the soul's suffering as basis of "higher revelations" (love), this division of sculpture and painting corresponds to the division between the most perfected of ancient and modern art. As we saw, in Chapter 4, this division between ancient and modern art rested on the revelation of Christianity, which transfigured fate into providence and necessity into freedom, and broke with nature to introduce the moral and ideal world. It would seem that this account informs that of the Münchener Rede, but it is noteworthy that the first principle of this text is not explicitly Christian. Schelling is less specific about why the transition from the ancient world to the modern world occurred, then he is about that it occurred. The only remnant of the Philosophy of Art's Christian mythology found in this address is that the content of painting possesses universality, which is a feature of the Christian religion. In any case, the history of nature and the arts of antiquity-from severity, to grace, to love- recurs in the "boundless universality of painting" exhibited in the work of the great masters: Michelangelo, Correggio, and Raphael (MR, 349/7: 318).

The discussion of painting in the Münchener Rede seems to be the peak of the text, where Schelling treats his audience to a paean dedicated to the classicism of the

${ }^{34}$ Compare to the $P A, 126-160 / 5: 517-568$. 
Renaissance. ${ }^{35}$ First, Schelling states, Michelangelo presents the epoch of nature struggling toward form, including the "untrammeled energies in monstrous births," the myths of a primeval world, the "heaven-storming" Titans, and the predominance of natural energy over charm. The second epoch is exhibited in Correggio, the painter of grace, who demonstrated the sensuous charm closest to antiquity, and whose "total expression" of chiaroscuro merged the darkness of matter with light, fusing them into one essence. Finally, with Raphael, the soul is turned toward the divine in "perfect equipoise." At this peak of human spirit and the divine, Raphael is "no longer a painter, he is a philosopher, and poet at the same time." He writes, of Raphael,

After the confines of nature have been overcome and the monstrous, the fruit of the initial liberty, suppressed and shape and form beautified by the presentiment of the soul: the heavens brighten, the softened earthly is able to merge with the heavenly and the latter in turn, with the gently human (MR, 351/7:320).

Therefore, for Schelling, painting presents the same sequence that is revealed in nature itself. The troika of the Italian masters, interestingly, in Schelling's interpretation, reproduce the mythological content of antiquity (the gods of art, discussed in Chapter 4.4) even where, curiously, the subject matter of the painting is drawn from Christianity, such as The Last Judgment. Schelling's accuracy, however, is less important for our inquiry than the fact that he has collapsed all the distinctions found in the Philosophy of Art into the search for one common power, or Urkraft, that realizes itself in nature, humanity and the arts, a unification of the true, good and beautiful in the ethic of artistic production.

Now, at the pinnacle of the Münchener Rede, we can take stock of the relationship between the plastic arts and nature. While much of his interpretation of particular artists or artworks remains similar to the Philosophy of Art, their relationships have changed between

\footnotetext{
${ }^{35}$ The following paragraph is a summary of $M R, 350-351 / 7: 318-320$.
} 
Jena and Munich. The most general shift occurs in the relationship between the plastic arts: the Münchener Rede omits the account of music, and Schelling has modified the organization of painting and sculpture. Where in the Philosophy of Art sculpture was the indifference point and painting was the predominantly ideal, the Münchener Rede drops the formal structures of identity-philosophy to argue that both reveal the same sequence found in nature, although one expression is ancient, and the other is modern.

And, as Marquet argues, the modified sequence of the Italian masters is telling: Schelling modifies their succession in inserting- "regardless of all chronology"- Correggio between Michelangelo and Raphael. ${ }^{36}$ This minor detail reveals the important shift between the Philosophy of Art and the Münchener Rede. In the former, Schelling organizes the potencies from the first (the origin) to perfection (the "grand style" of the indifference and identity of real and ideal) to the second, which portrays decadence and an excess of soul. We already have seen this, above, in the philosophy of music, wherein rhythm and melody are respectively origin and perfection, while harmony is a modern excess of ideality. This order and value of potencies is also seen in the account of Italian painting, which progresses "from the severity of Michelangelo to the softness of Correggio by the unique point of perfection, Raphael...the beginning is marked by a kind of excess of formal rigor...[the second potency] on the contrary is an excess of soul, intellectuality, of sense: the central perfection is the equilibrium of the two." ${ }^{, 37}$ In the Philosophy of Art, then, Correggio's work is the fall toward decadence or intellectuality, or even softness; in the Münchener Rede, the excess of soul comes after the troika Michelangelo-Correggio-Raphael, in the work of Guido Reni

\footnotetext{
${ }^{36}$ This paragraph follows Marquet, "Schelling et le destin de l'art," in Actualité de Schelling. Ed. G. PlantyBonjour (Paris: Vrin, 1979), 85-86. Here are the chronological dates: Michelangelo (1475-1564), Correggio (1489[?] -1534), Raphael (1483-1520), and Guido Reni (1575-1642); for an explanation of Reni's inclusion in this list, see below.

${ }^{37}$ Marquet, "Schelling et le destin de l'art," 85-86.
} 
(MR, 352-353/7: 320-321). Nevertheless, the chronological imposture indicates that Schelling had to finesse the history of painting to make it correspond to the revelation of nature and sculpture found in the Münchener Rede, that is, to fit painting into the common schema of the revelation of nature, humanity and art.

We can summarize by showing that the three necessary conditions of the philosophy of art obtain. For Condition 1, the argumentative structure of the Münchener Rede shows that art presents in the real what philosophy only demonstrates ideally: Schelling's claims about the 'evolution' of nature are not supported by complex proofs drawn from contemporary science, but rather are supported by the philosophical interpretation of artistic sequences. This is precisely why we have said that art brings forth the bringing-forth of nature, that art is the revelation of revelation itself. For Condition 2, I have argued that the Münchener Rede maintains that art is produced through the reestablishment of equilibrium between the parts of soul, which are interrupted by the passions. While the epistemological implications are lacking, this argument corresponds to the previous presentations of the philosophy of art where artistic production is a higher potency than nature because it presents the identity of freedom and necessity, conscious and unconscious, and real and ideal, after these oppositions are produced, thus producing a reconciliation. And, while we will address the topic below, we can anticipate Schelling's conclusion by noting that the Münchener Rede closes by calling for a renewal of art (Condition 3); not specifically as a new mythology, but Schelling's presentation as such is itself establishing the frame of reference for a modern mythology should such an artistic renewal arise in Germany.

The possibility of this renewal of mythology rests in the productive capacity of nature itself. Schelling does not discuss the Italian renaissance, for example, as a model for 
imitation, instead, he argues that the contemporary artist should bring forth the same inspiration as the Italian masters: a "different inspiration falls to the lot of different epochs...an art the same in all respects as that of past centuries will never come again; for nature never repeats itself" $(M R, 356 / 7: 327-328)$. Thus the originality of the art to come is rooted in an implicit historicism and emphasis on finitude, on the particular social context in which art arises. That this context is conceived as the place and time of a people or nation has clear political implications that we will discuss below (in Section 5.4). At the moment we will complete our account of the Münchener Rede by turning to the question of what god is, or, who is this god, revealed through this history?

What, of course, appalled Jacobi about Schelling's address was what appeared to be a kind of vitalistic pantheism. ${ }^{38}$ While Jacobi may have not been, in this case, the best listener, Schelling's presentation is unclear: instead of Gott (the name of the absolute in the Philosophy of Art), he relies on the more neutral Wesen (which, accordingly, I have translated as 'essence,' although it could also be rendered as Being), even if the Philosophy of Art possessed a much stronger rationalist-Spinozist core. Jähnig utilizes Schelling's later distinctions between ground (Grund), essence (Wesen) and existence (Existenz) or appearance (Erscheinung), to make sense of the first principle or deity at the center of the Münchener Rede: ground and essence are separated by the appearance. ${ }^{39}$ Ground and essence are separated by existence of history because essence can only be realized through opposition and self-affirmation. Schelling's Wesen seems to be impersonal. Although the

\footnotetext{
${ }^{38}$ Jacobi writes: "Schelling's creation of the world (Weltschöpfer) produces, from a world without end, nothing other than time... The one nontemporal Life... is transformed into an infinitely multiple transience so that Life is lived. There is only one quality, Life as such. All other qualities or properties are only different quantities or restrictions of this one quality, which is at the same time substance and all reality (Wesen). Mankind has thereby more [reality] than the dung beetle, but in itself nothing better or higher. All that lives only lives the one and the same Life" (Jacobi to Fries, November 26, 1807, in Sziborsky, "Aus zeitgenössischen Briefen," 74).

${ }^{39}$ See Jăhnig, Schelling: Die Kunst in der Philosophie. Vol. 2, 259.
} 
Wesen opens toward self-revelation, this is not explicitly based on any type of religious series, but rather it follows the outline of a history of art. The emphasis on nature as primal power (Urkraft), whose creation is made conscious through the repetition of artistic creation, has the sound of a through-going pantheism. But the 'historical revelation' runs counter to eternal and immutable Spinozist substance.

In the texts immediately following the Münchener Rede, Schelling turns to revelation to answer "who is this god?" In doing so, he introduces, against his previous Spinozism, a personal God, who is revealed within history. In this transformation, the primacy of the philosophy of art, and its insistent problem of the separations of art and nature, model and image, real and ideal, are replaced with a 'living idea of freedom' and a theological anthropology based not in artistic production, but the Fall of humanity.

\section{3. ...to Theological Anthropology}

The Stuttgart Seminars offer the most immediate contrast to the philosophy of art of the Münchener Rede because it discusses the essence of God, His revelation in history, and an anthropology and its relationship to art. Yet where the Münchener Rede is arguably Schelling's most pantheistic and pagan text, the Stuttgart Seminars present a history grounded in a series of revelations deeply indebted to Christian theology; while the Münchener Rede points toward the future through its call for a renewal of a national art, the Stuttgart Seminars are oriented toward the past, and more specifically, on the self-revelation of God and an anthropology based on both the Fall of man (as a historical event, not a mythological symbol) and the redemption of Christ, the latter of which forms the basis of human freedom. This shift in orientation, which seeks to explain human freedom and the 
origins of good and evil through the Fall, is the most obvious indicator that (to paraphrase Hegel's well known verdict on art) the philosophy of art, considered as the highest vocation, is for Schelling a thing of the past. If we are searching for immanent tensions in Schelling's philosophy, they have shifted from the relationship between philosophy and an artistic ethos to that of the tension between the system and freedom, where we began in the Letters, although, of course, their relationship has changed.

In the Stuttgart Seminars, Schelling's anthropology is fundamentally bound to the Fall of Man as a historical event. ${ }^{40}$ This inclusion of the Fall into history marks a decisive break (already seen in Of Human Freedom) with the orientation of the Münchener Rede, which was turned toward the future renewal of art. That the Fall is a necessary event, Schelling argues, can be seen by 1) the present form of nature, which appears in an opaque lawfulness that still appears to lack total necessity, and which remains in a constant state of unrest when it should have attained perfection; and this argument is supported by 2) the presence of evil in the moral world and the presence of poison, disease and death in the natural world $(S P, 225.7: 459)$.

This argument is based on Schelling's conception of the relationship between nature and God. In this account, Schelling conceives of God's revelation through the potencies ${ }^{41}$ of ground, existence (Existenz) and essence (Wesen), which form the foundation of God's selfrevelation as an event, and the basis of history and human freedom. While the Münchener Rede constrained its references to a more neutral Wesen, the Stuttgart Seminars attempt to show how this tripartite structure reveals the personal God that was only previously hinted at in the last text of the philosophy of art. The first stage is that of the ground, what Schelling

\footnotetext{
${ }^{40}$ See also Marquet, Liberté et existence, 431-448, and Marie-Christine Challiol-Gillet, Schelling, une philosophie de l'extase (Paris: Presses Universitaires de France, 1998), 163-176.

${ }^{41}$ Schelling has returned to the usage of Potenz for potency.
} 
calls the 'contraction' (Contraktion) of God, in which God raises himself from the formless and affirms His individuality by separating out what is not of His essence: nature as primal matter. As Schelling states, "God separates Himself as being (Seyendes) from His Being (Seyn)" (SP, 208/7: 436). Or, in our terms, God sets His existence (Seyendes) in opposition to his ground (Seyn). This opposition is the basis of all life and history; "without opposition [there is] no life" ( $S P, 208 / 7: 435)$. This opposition, Schelling argues, is a progressive revelation of the absolute, from ground to essence. ${ }^{42}$ In the middle of these two points, in His existence, God reveals himself not just as personality and individuality, but also as divine love, which gives form to primal matter, and in divine love, nature, history and humanity are grounded.

Humanity stands at the center of existence, between nature and the divine, the consciousness awakened from the unconscious activity of nature (SP, 208/7: 435), and therefore human being, or spirit, is divided between temperament (Gemüth), spirit (Geist) and soul (Seele): temperament is the natural or dark principle, soul, the light or divine principle, and spirit their indifference or bond. Human freedom, Schelling writes, "consists precisely in the spirit being subordinate to the soul on the one hand while standing above the temperament on the other" (SP, 234/7: 471). The Fall, and evil, happened because humanity elevated the natural principle over the divine, and cut its ties with God. However, Schelling maintains that this bond between the divine and the human was restored through Christ's sacrifice, which was revealed as the model of human freedom and which showed, through his actions, what the original relationship between humanity and nature was supposed to be $(S P, 228 / 7: 463)$. To show precisely what is divine in the human, and what is of nature,

\footnotetext{
42 Thus the Stuttgart Seminars close with an account of the final judgment, when God is revealed as "divine matter," visible and corporeal, the basis of all that is: "Then God is in all actuality everything, and pantheism will have become true" (SP, 243/7: 484).
} 
Schelling turns to a theological anthropology, in which it becomes clear that virtue and religion, and not artistic production, are now the highest potencies of human activity. ${ }^{43}$

Table 5.2: The Divisions of the Spirit

$\begin{array}{llll} & \text { Temperament } & \text { Spirit } & \text { Soul: expressed as: } \\ \text { Temperament } & \text { Longing } & \text { Egoism } & \text { Art and Poetry } \\ \text { Spirit } & \text { Desire } & \text { Proper Will } & \text { Virtue } \\ \text { Soul } & \text { Feeling } & \text { Understanding } & \text { Philosophy }\end{array}$

As mentioned above, Schelling divides human being between the temperament, spirit and soul. This is similar to the tripartite schema of the Münchener Rede (the passions, spirit and soul), but the Stuttgart Seminars create additional complexity by showing how the three potencies relate to one another. Temperament has its basis in the dark or natural principle, and its first potency realized in longing (Sehnsucht), which is expressed in melancholy. Schelling states that melancholy is manifested by all life, because life is grounded on something separated from it, just as human being is not identical to either nature or God ( $S P$, 230/7: 465-466). The second potency of temperament is desire or appetite (Begierde), which is an insatiable "hunger for being (Seyn)." Recall that Seyn is the dark or natural principle of humanity, and thus the appetite is basis for the desire to overturn the divine principle and turn one toward evil. The third power is that of feeling (Gefühl), which is the ideal expression of temperament.

The second general potency is spirit and personality, which is divided into the individual will (Eigenwille), the understanding (Verstand) and the proper will (eigentliche Wille): the first is the basis of individuality, the second the act of cognition and the third the point of indifference; the proper will mediates between the temperament and the soul. This stance rests on Schelling's argument that spirit cannot be the highest potency because it is

\footnotetext{
${ }^{43}$ Recall Marquet's argument about the growing emphasis on the role of Christ in the universe in "Schelling et le destin de l'art," 87.
} 
the point, in its relative independence from both nature and God, in which human freedom is enacted for good or evil. As mentioned above, evil is not privation, but a reversal of principles; it is the inversion of the natural principle over the divine, and it "wages the most vehement war against all being (Seyn); indeed, it wishes to cancel (aufheben) the very ground of all creation" (SP, 232/7: 468).

By contrast, if the spirit is subordinated to the soul, the highest activity of humanity becomes possible. Unlike the previous two potencies (temperament and spirit), the soul is undivided; however, it may express itself in relation to the lower potencies to produce art, philosophy, and the aforementioned highest activity, virtue. This order of the soul's expressions, or products, shows how Schelling's thought has changed. The first important shift is in his conception of philosophy, which is the result of the soul's activity with the understanding and feeling. The understanding is no longer interpreted as merely an inferior faculty of reflection opposed to intuition (reason), but as a personal aspect of knowledge, as opposed to the impersonality of reason, and there is also a theological aspect to this division: "the spirit has knowledge because it also contains the possibility of evil" (SP, 232/7: 469). Hence understanding is considered as an activity (it can choose, through its knowledge, to partake in good or evil), while reason is the "understanding in its submission to the higher [potency] of the soul" (SP, 234/7: 472). Schelling draws an analogy between reason in philosophy and pure space in geometry: in geometry, a false concept "will not be accepted by space but is rejected; e.g., a triangle whose longer side were to face the smaller angle" $(S P, 235 / 7: 472)$. Likewise reason will reject all that is not submitted to the soul, as that which still bears the subjective traits of personality. The passive role of reason can also be

\footnotetext{
${ }^{44}$ Marquet shows how this shift is anticipated in several of Schelling's works from 1806-1808, although understanding does not yet have a theological aspect. See Liberté et existence, 355-356; 441.
} 
explained by the change in Schelling's view of what a system can do: where in identityphilosophy, it was necessary to construct the system of reason as it was in nature, after the Münchener Rede, it is necessary to discover in all its obscurity the system of the world itself. Systems created by philosophers are more like "historical novels." By contrast, Schelling claims that

long before man decided to create a system, there already existed one: the system of the world (System der Welt). Hence our proper task consists in discovering that system. The true system can never be created [by the philosopher] but only uncovered as one that is already inherent in itself; that is, in the divine understanding ( $S P, 197 / 7: 421)$.

This world-system ultimately rests on God's revelation. Reason is the process whereby the personality of the understanding is rejected for the soul and the divine. We can state, then, that reason plays a negative role, or a critical function, but it cannot discover a priori the positive revelation of the system. Instead, God's revelation must be His inner law, not an external law. So if Schelling calls previous systems, such as Leibnizianism, historical novels, it is because they began with external laws, such as the law of sufficient reason (which was at the center of the Pantheism Controversy), and then applied them to God. For Schelling, if such laws obtain, it is only through God that they do; they are all God's inner laws, and His revelation has mastery over them. To illustrate this point, Schelling cites the last stanza of Goethe's poem Natur und Kunst, the first stanza of which served as the epigram to this chapter, but what he quotes, and what he does not, reveals how much the central tensions in his thought have been transformed. Contraction, Schelling argues, is not negative, but an affirmation of mastery over the lower potencies:

Wer Großes will, muß sich zusammenraffen; In der Beschränkung zeigt sich erst Meister. 
In Michael Hamburger's translation this passage reads: "Who seeks great gain leaves easy gain behind. None proves a master but by limitation" ${ }^{45}$ As quoted, the poem stresses the character of creation, but just as important is what he left out. The final line reads "Und das Gesetz nur kann uns Freiheit geben," which Hamburger translates as "And only law can give us liberty" (since we need not rhyme, read 'freedom' for Freiheit). This omission of law from freedom, I think, shows that Schelling no longer thinks freedom as law, as a regulative moral law, or as a negative concept (which is precisely why he turned toward an ethic of artistic production). The positive character of freedom, its ecstatic character, cannot be determined by a priori through practical philosophy. And thus philosophy, which has the task of discovering the "progressive demonstration of the absolute," $(S P, 199 / 7: 424)$ is not the highest activity. The highest activity is virtue.

Virtue, Schelling argues, arises in the interaction of the soul and will and desire. This interaction is the basis of freedom, and with the proper order of principles (when the spirit stands above desire, but is subordinated to the soul) brings about "virtus, purity, propriety and the fortitude of the will" (SP, 235/7: 473). Like the rejection of the priority of law over revelation, Schelling rejects the formalism of previous accounts of practical philosophy. Schelling writes:

The truth of the different systems of morality, of Epicureanism and Stoicism converges, I believe, in the following, supreme principle: "Permit the soul to act within you, or act as a thoroughly holy man." Kant has [kept] from that principle merely the formal expression. "Act according to your soul" means as much as to act not as a subjective being (persönliches Wesen) but in an entirely impersonal manner, without allowing your subjectivity to disrupt its influence on you ( $S P, 235 / 7: 473)$.

${ }^{45}$ Berliner Ausgabe, 121; the translation is in Selected Poems. Ed. Christopher Middleton (Boston: Suhrkamp, 1983), 164-165. 
While Schelling agrees that impersonality is the highest and divine potency, he rejects Kant's interpretation of the moral law as a regulative idea. In Schelling's reading, a regulative idea conceives of activity as approximate, that the finite subject can only infinitely approximate the divine (hence "Act according to your soul"). Schelling's reversal of this maxim rejects the formalism by placing the divine in nature through the mediation of humanity (hence "Permit the soul to act within you, or act as a thoroughly holy man."). Thus the products of freedom- virtue, the good, and evil- are realized within the finite world. In virtuous activity, humanity takes God's revelation as a model. Just as god separates "Himself as being (Seyendes) from His Being (Seyn), [in] the highest moral act" man separates his being (Seyendes) from his ground (Seyn) (SP, 208/7: 436).

Because, now, Schelling holds that freedom realizes its activity in the finite world, and does not just infinitely approximate the moral law, just as God's revelation and human virtue take on the character of inner law giving, art becomes subordinated to philosophy and virtue. The holistic ethos of the Münchener Rede, which unified the true, the beautiful and the good, is once again separated. Art and poetry, according to the Stuttgart Seminars, is the expression of the soul in relation to longing (in the temperament) and the individual will (in the spirit). While Schelling holds art to be "entirely ideal and yet as real as a work of naturewhich is innocence restored" $(S P, 234 / 4: 471)$, this stance fulfills none of our conditions for a philosophy of art. Where art was once the expression of the highest potency, it is now the expression of the longing for a lost object, and even a kind of naïvety ${ }^{46}$; where a new mythology once held out the expectation of the reconciliation of humanity and nature, now

\footnotetext{
${ }^{46}$ In E.F Georgii's notes on the Stuttgart Seminars- corrected by Schellling himself-, Schelling states that "If the soul relates to longing and ego dynamism (Selbstkraft), [and] if it stands in conjunction with longing, then it [the soul] creates art. In art individual will and ego dynamism appear in their naivety." Stuttgarter Privatvorlesungen. Ed. Miklos Vetö (Turin: Bottega D’Erasmo, 1973), 189.
} 
Schelling holds that only religion can effect this reconciliation. Now that we have seen how art is subordinated, in the Stuttgart Seminars, to science (philosophy) and virtue, we will conclude by examining the political destiny of the new mythology.

\subsection{The Politics of Mythology and the Mythology of Politics}

One of the most important consequences of artistic production is political. Because art expresses the idea- the absolute- in the finite world, it possesses the ability to render the idea sensible. This is, for Schelling, the unique power of mythology, and it was the concept of a new mythology that opened the possibility of a future reconciliation of the divisions that define modernity. We will conclude, then, by examining the ambiguous politics of mythology, as it shifts from revolutionary enthusiasm to a mythologization of politics.

The conditions of the emergence of the idea of a new mythology should not be ignored: the critique of representation engaged by the early Romantics and German idealists is not just a philosophical issue but a political one. The fundamental political problem is the relationship between the individual, groups (whether conceived as nations, peoples, communities, parties, movements, classes, etc.), and the state: should their relationship be governed by representation, wherein individuals or groups interact within a social framework organized toward maximizing formal rights, or is there another way to conceive of this relationship? Is there not a purpose to which the state should be subordinate? We, of course, cannot resolve this question here, but we can evaluate Schelling's approach to the question through his work on new mythology, society, and the state. As Manfred Frank argues, the new mythology emerges as renewal of the public sphere, but it is important to show how Schelling's various conceptions relate to this public sphere, for they are not all 
alike. While Schelling recognizes the 'legitimation crisis' that had emerged in Germany in the transition to industrial capitalism, his various presentations on the new mythology supply different solutions to this crisis. ${ }^{47}$

Whoever the author, the idea of a new mythology first appeared in the "System Program" as the touchstone of a new, emboldened, post-Kantian philosophy. In this brief text, the new mythology, in mediating 'the monotheism of reason and polytheism of imagination' shines with revolutionary fervor, above, and in contrast to, the lifeless mechanism of the state. As mechanism, the state has no true idea, and hence any idea of freedom must aim for some higher purpose, which ultimately is that of beauty, in which the good and the true are unified. The purpose of the new mythology is to make this unity of the good, true and beautiful sensuous, to bring forth a sensuous religion and mythology of reason; its task is formative (in the sense of Bildung): to educate the people (Volk) through poesy. The defining feature of this mythology, insofar as it unites the various 'revolutionary' classes (divided here between philosophers and the people as the masses), against sages, priests and the state, is that the "eternal unity" it brings about is conceived as egalitarian. The state cannot realize true freedom- egalitarianism- through its formal mechanisms; some higher idea must govern the philosopher's inquiry. Against the hierarchies of statism and institutionalized religion, the "System Program" is clearly animated by the author's enthusiasm for the French revolution.

By the time of the System of Transcendental Idealism, Schelling's revolutionary enthusiasm had been tempered, although the idea of a new mythology maintained its sociopolitical prominence. It was one thing to suggest the unity of the good, true and beautiful

\footnotetext{
${ }^{47}$ Manfred Frank, Der kommende Gott: Vorlesungen über die Neue Mythologie. Vol. 1 (Frankfurt: Suhrkamp, 1982), 153-211. The manner in which Frank cites Schelling's various presentations overlooks their important differences that I develop here chronologically.
} 
within a new mythology; it was another thing entirely to render this unity systematically, and the resulting difficulties are on display in the System of Transcendental Idealism. There, the opposition between practical philosophy and the philosophy of art results in an inconsistent separation of history and mythology. While in Chapter 3, we focused primarily on the difficulties with unifying Schelling's idea of providence with the announcement of a mythology to come, the same problems hold for the relationship between the state (which we discussed with reference to the philosophy of history) and mythology. In the System of Transcendental Idealism, the state is conceived as a mechanism for the realization of individual rights, although it cannot maintain any moral force, because "all attempts to transform [the state] into a moral order present themselves as detestable through their own perversity, and through that most dreadful kind despotism which is their immediate consequence" (ST, 196/3: 584). Although the state acts materially like providence (that is, toward the collective realization of freedom), it does not do so in form, nor with judgment and forethought. Hence the state, with its foundation in natural law, is subordinated to providence, which is a higher realization of freedom in history. Even in the practical section of the System of Transcendental Idealism, the state is subordinate to a higher principle, which is perhaps Schelling's version of the revolutionary thesis calling for the withering away of the state. Yet this does not render the relationship between providence and the new mythology any more consistent. It is clear, in any case, that the potential of mythology is superior to Schelling's cursory and unenthusiastic deductions of the role of the state in the system.

Nevertheless, the System of Transcendental Idealism displays a cosmopolitanism (in the Kantian sense) lacking in Schelling's later presentations on the relationship between art, 
the nation and the state. In both the System der gesamten Philosophie und der Naturphilosophie insbesondere (of 1804, which we will refer to as the Würzburg Lectures) and the Münchener Rede, Schelling no longer opposes mythology and the state. Instead, the new mythology, or a renewal of artistic creation, will contribute to the formation of the state as a moral force. The shift toward the mythologization of politics parallels a change in Schelling's conception of the state, for in the latter texts, he argues against Kantian cosmopolitanism in the favor of the organic state (6: 575), and enlightened paternalism ( $M R$, 355/7: 327). Then, the appearance of a new mythology becomes the means of public participation within the paternalist and monarchist state. Or, to make a more critical assessment: mythology becomes the ideological representation of public participation: one can participate through a public set of rituals and beliefs without participating in the structures of political empowerment.

In the Würzburg Lectures, Schelling presents the state as the ultimate realization of science, religion and art. His remarks on art are brief, and are oriented toward his conception of a public sphere. As Schelling states, the modern world lacks a proper Symbolik (6: 571), which, in German usage, is "not only a system of symbolism but also a coherent doctrine of faith." ${ }^{48}$ As mentioned in the Philosophy of Art, the modern condition has only created partial and fragmentary mythologies, such as in the work of Dante, Shakespeare, Cervantes and Goethe (6: 572) ${ }^{49}$ The diagnosis, according to Schelling, is that a truly public sphere can bring about a truly organic state:

Where all public life collapses into the particulars and dullness of private life, poetry more or less sinks into this same sphere... But even mythology is not possible in the particular; it can only be born in the totality of a nation that as

\footnotetext{
${ }^{48}$ George S. Williamson, The Longing for Myth in Germany (Chicago: University of Chicago Press, 2004), 336, n. 35 .

${ }^{49}$ On Dante and Goethe, see Chapter 4.4.
} 
such acts as identity [or] an individual. In dramatic poetry, tragedy grounds itself in the public law, in virtue, religion, heroism - in a word- in the holiness of the nation. A nation that is not holy, or which was robbed of its holy places, cannot have true tragedy...the question of the possibility of a universal content of poesie, just as the question of the objective existence of science and religion, impels us to the highest itself. Only in the spiritual unity of a people, in a truly public life, can the true and generally valid poesie arise- as only in the spiritual and political unity of a people can science and religion find its objectivity $(6: 572-573)$.

The political unity of a people arises organically in the nation-state, not in the private pursuit of individual right within a state. Instead, the state develops organically, through the development of religion, science and art, into their highest expression. As Schelling recognizes, this state has never existed, but he is here giving a prescriptive account of a future state. The important shift to recognize is that the state is the apex of the system. Unlike the previous potencies- science, religion and art- the state is Potenzlos, which means that it has no opposition; any opposition is the result of the state oppressing one or more of its living elements (6: 575). Although he gives very little indication of how this state is to come about, he claims that the relationship of reason to the universe is analogous to that of philosophy to the state: just as reason realizes itself in the universe, philosophy realizes itself through the public life of the state.

Despite the lack of an explicit reference to idea of a new mythology, the Münchener Rede is not just about the common source of nature, history and art; it also argues for a thoroughgoing renewal of art within the German Volk. The entire question of how nature should inspire art is not only of interest to the art historian, but rather points forward toward the realization of art within a unified people or nation. The task, for the artist, is to draw inspiration from nature in order to renew German art. Just as German thought brought forth a revolution in thought, so should it bring forth a revolution in art: 
This people (Volk), from which the revolution of thought in the new Europe proceeded, to whose intellectual power the greatest inventions bear witness, which has given laws to the heavens and whose investigations have penetrated most deeply into the earth, in whom nature has implanted more deeply than any other a steadfast feeling for the right and an inclination toward the recognition of first causes, this people must reach its conclusion in an original art $(M R, 357 / 7: 328)$.

Thus the advances of German thought remain ideal; artistic production, then, still functions in the role of the new mythology, insofar as it should, according to Schelling, realize the revolution of thought for and through the people. ${ }^{50}$ This, I think, designates an inchoate project of nationalism that conceives of a people as an organic totality. By contrast, Peter Oesterreich argues that Schelling's call for an original German art is not nationalistic. That Schelling recognizes the originality, and singularity of other national arts (such as the Italian Renaissance) shows a national pluralism: "for Schelling, the visible principle of original variations should also rule the world of nations. The equality (Egalität) of peoples, therefore, does not consist in sameness (Gleichheit), but rather the similar originality of their cultural forms, which present themselves as characteristic art." ${ }^{51}$ The problem with this argument is that recognizing the diversity of cultural forms is not incompatible with nationalism. Schelling also 'recognizes' the singularity of the French, who "have an exclusively literal understanding of almost all the more exalted subjects," in a long excursus on the misunderstanding of what it means to imitate or emulate the ancients (MR, 364/7: 325). Yet it is not just that Schelling is juxtaposing the virtues and vices of peoples (who are interpreted as nations), but that his conception of a people is that of an organic totality, a

\footnotetext{
${ }^{50}$ Recall Marx's sarcastic remarks, made decades later, that "we Germans have experienced our future history in thought, in philosophy. We are philosophical contemporaries without being historical ones. German philosophy is the ideal prolongation of German history." Karl Marx, "Toward a Critique of Hegel's Philosophy of Right: Introduction" in Selected Writings. Ed. David McLellan (Oxford: Oxford University Press, 1977), 67.

${ }^{51}$ Peter L. Oesterreich, "Die Gewalt der Schonheit" in Schellings Weg zur Freiheitsschrift. Legende und Wirklichkeit. Ed. Hans M. Baumgartner, Wilhelm G. Jacobs (Stuttgart-Bad Cannstatt: Frommann Holzboog, 1996), 107.
} 
concept with dangerous political implications because it masks the internal divisions of society with an ideological homogeneity, excluding in practice those who are not properly members of the community. This imagined homogeneity of a people is the problem with what I have called Schelling's mythologization of politics.

Thus when the Münchener Rede praises the "charitable dominion of a paternal regent" who allows for the proper cultivation for the public reception of art, these compliments are not politically neutral $(M R, 355 / 7: 327)$. The superiority of the paternal regent arises from preventing the leveling that Schelling associates with democracy in general and the French Revolution in particular, which he claims subordinates the majesty of artistic creation to popular applause. Bavarian paternalism according to Schelling, by contrast, allows for the cultivation of the firmly established taste and public opinion of a whole people $(M R, 355-356 / 7: 327){ }^{52}$ The cultivation of the public sphere thus becomes an ideological justification for the Bavarian state-form.

We have primarily focused on the ideological component of the mythologization of politics, and the features which can, beyond the work of Schelling, justify either antidemocratic or oppressive measures when they are taken up within a statist or nationalist project. It would be an incomplete and undialectical (and very Lukacsian) account of Schelling's politics if we did not also discuss the material conditions of this ideological position. Hence, we should turn to Schelling's situation in Munich, where it appears, despite all the grandiose rhetoric of the Münchener Rede, that he also had a much more practical and pedagogical goal.

\footnotetext{
52 Concerning the French Revolution, see also On University Studies. Trans. E.S. Morgan (Athens, Ohio: Ohio University Press, 1966), 52-55/5: 258-261.
} 
Schelling contributed to the cultivation of the public sphere from 1808-1821 through his appointment as Secretary General of the Akademie der bildenden Künste in Munich. Sziborsky argues that Schelling's involvement included writing the constitution of the Akademie, in which he thought he saw most of his ideas realized as the means by which the constitution provided for a society for art open to the larger public for the purposes of appreciation and cultivation. ${ }^{53}$ In an essay published in 1808 , despite its largely descriptive tone, Schelling again reaffirms his views that mythology should be cultivated as the living ideal of art, and that this art is grounded in the essence of a nation (7: 559-560, 567-568). But if pedagogy is the goal, these stances have much less ideological and political force, and sound, in this context, like a hyperbolic grant application: it is not that the renewal of art justifies the state, but that an art institution musters all the available arguments it can for continued patronage. Ill advised, though hardly a trip to Syracuse, as it were. In fact, soon Schelling's enthusiasm for art would wane, due, in all likelihood, to his change in philosophical orientation toward the relationship between freedom and system. ${ }^{54}$

With this change in orientation, found in the Stuttgart Seminars, Schelling included a critique of the state, and by consequence, a self-critique. There the inclusion of the Fall into his account of history leads to a re-conceptualization of the state as an external or material unity, or even a "consequence of the curse that has been placed on humanity" $(S P, 227 / 7$ : 461). At its basis, the state cannot escape the central contradiction of moral force: because morality is a higher potency than the institution of the state, any attempt to realize a moral power through the natural means at its disposal (whether in the French Revolution or

\footnotetext{
${ }^{53}$ See Lucia Sziborsky, "Schelling und die Münchener Akademie der bildenden Künste," 39-64. Sziborsky also mentions that the constitution of the Akademie, in comparison to the constitutions of other academies at the time, is fairly progressive in its mandate.

${ }^{54}$ See Tilliette, "Schelling, l'art et les artistes," xxxvii-xlvii.
} 
through Kantian concepts) will result in failure. If the state realizes the conditions of the highest realization of freedom, then it is deprived of coercive force, or, granted coercive force, it turns to despotism (SP, 227/7: 461-462). The possibility of the unity of humanity, and its realization through freedom, is only possible through religious knowledge:

only the supreme and most diverse culture of religious knowledge will enable humanity, if not to abolish the state outright, then at least to ensure that the state will progressively divest itself of the blind force that governs it, and to transfigure this force into intelligence. It is not that the Church ought to dominate the state or vice versa, but that the state ought to cultivate the religious principles within itself and that the community of all peoples ought to be founded on religious convictions that, themselves, ought to become universal $(S P, 229 / 7: 464-465)$

If Schelling still has a program, a 'system-program,' as it were, for the future, or for some way to reconcile the fragmentary condition of humanity, it is through religious study: not through the institution of the church (itself divided internally and externally), but through the study of that peculiar doctrine of knowledge itself, philosophy. For Schelling, this will take place far from the public eye, until his arrival in Berlin in 1841, ten years after the death of Hegel, and seven before the publication of The Communist Manifesto. The development of subsequent answers to the problems of modernity and its philosophy, which, in the $19^{\text {th }}$ century, included positive philosophy, the phenomenology/philosophy of spirit, and historical materialism, is itself another story. 


\section{Conclusion}

In the Stuttgart Seminars (1810), Schelling returns to the question of the relationship between freedom and the system, which is exactly where the Letters (1795-1796) began. I have argued that the path from freedom to artistic activity and back is everything: Schelling's return to the primacy of freedom should be understood by way of his development of a philosophy of art. This philosophy of art, which holds that artistic activity realizes the ideas of philosophy in the world, anticipates his philosophy of freedom, wherein Schelling develops an ecstatic account of freedom that is thought as a creative force within finitude, and not a formal conception according to the imperative of a moral law. To conclude I will reconstruct Schelling's path toward a philosophy of freedom.

In the Letters, Schelling argues that a philosophy can only be realized through practical activity. He distinguishes between two contending systems: criticism, which begins with the subject as its first principle, and dogmatism that begins with the object. In short, Schelling presents a philosophical contest between Fichte and Spinoza. Neither can ultimately refute the other theoretically, only practically. In the practical sphere, Schelling argues that criticism presents a superior system. In practice, dogmatism identifies the finite self with the absolute object, and hence it risks moral extinction, because in dogmatic philosophy the finite self's activity is identified with objective necessity. By contrast, critical 
philosophy sets out from the self's activity which infinitely strives toward the absolute. Criticism is a superior system practically, Schelling argues, because it can account for the infinite activity of the self.

Although maintaining much of Fichte's defense of practical reason, Schelling anticipates something of his later philosophy of freedom in the Letters. It seems Schelling himself had not seen all the implications of his argument, but as I have noted, his overall account of freedom is ambiguous enough that he later reads several of his own concerns into the Letters. Nevertheless, what concerns this study is that, momentarily, the Letters anticipate his ecstatic account of freedom. In the Sixth Letter (discussed in Chapter 1.4), Schelling argues that each truly ethical philosopher-and Spinoza is his example- lives his or her system. That is, the system is only realized through the activity of the self. This presents several problems for the dogmatist, who identifies his or her own actions with absolute necessity, thus misrecognizing the free choice at the basis of the system. The critical philosopher, however, not only holds that 'I act freely,' or that 'I will act freely,' but he or she also recognizes this free choice retroactively, in looking back at the initial act through the future anterior, that 'I will have acted freely.' The initial act, to draw a comparison with Schelling's later thought- not to mention, perhaps, Sartre-, is an ecstatic moment of freedom, and the question is then how to demonstrate how a system can be realized that accounts for this freedom. The primacy of freedom becomes even clearer when compared, in the Tenth Letter, to Greek tragedy. While tragedy presents the ultimate tribute to human freedom, it cannot be the basis of an ethics because the idea of fate diminishes the potential of freedom. So, where the critical philosopher states that 'I act freely,' the model of tragedy falters because it could allow the self to act in bad faith: 'I would act freely but for fate...' 
As I mentioned above, it does not seem that Schelling recognized the 'existential' consequences until later. In his philosophical development, the more immediately decisive step is the commencement of nature-philosophy (see Chapter 2). Even though Schelling ardently defends the idea of freedom, from very early on he recognizes that modern philosophy has an inadequate grasp of the problem of the relationship between the self and nature. As he notes, modern philosophy interprets nature predominantly as a mechanistic universe that has some unexplained relationship to the free activity of the mind, a stance that divorces the self from the world. In his later works, Fichte's categorical imperative- that all reality should conform to the self's activity- will represent, for Schelling, the pinnacle of the mechanistic and instrumental relationship of the self to nature within philosophy. To overcome the dualism of modern philosophy, Schelling draws on Spinoza, Leibniz and Kant's concept of teleology to show how self-consciousness emerges within nature. These ideas are further developed in the Introduction to the First Outline of a System of the Philosophy of Nature (1799), where Schelling argues, drawing on Spinoza, that nature is both producing (natura naturans) and product (natura naturata) (See Chapter 3.3). Nature produces with inner-purposiveness, that is, as both free and necessary. In this way it is similar to how he conceives the self's activity, which is grounded in the identity of freedom and necessity. The difference between the self and nature, however, is that nature does not produce with consciousness or intentionality. The entire problem is to show this identity for self-consciousness.

To show how the identity of freedom and necessity can be brought to selfconsciousness, Schelling introduces a philosophy of art. The philosophy of art takes on, as I have argued, a subversive character vis-à-vis transcendental idealism in his System of 
Transcendental Idealism, because Schelling shows how freedom or practical reason cannot ground the transcendental system (See Chapter 3). It cannot ground the system because practical reason is itself grounded through the division between subject and object. As Schelling argues, the self is both unconsciously productive and consciously productive, and this distinction makes the appearance of freedom possible. On one hand, the self produces representations of objects, and on the other, the self, as practical, seeks to transform objects according to its activity, but practical reason cannot overcome this distinction between the unconscious and conscious production (See Chapter 3.2.2). Instead, practical reason becomes the basis of the transcendental distinction between the in-itself and appearances. While in-itself the self's activity is both free and necessary, in appearance the self acts freely within a world of representations that bring with them a feeling of necessity. Schelling concludes that freedom is a necessary illusion, although only through practice do the representations of reality obtain. Thus practical reason cannot explain the identity of subject and object; rather, practical reason is explained by the distinction between subject and object.

By contrast, artistic production brings the identity of subject and object (as freedom and necessity, conscious and unconscious production) to self-consciousness because it produces this activity in the finite world (See Chapter 3.4). Where practical reason can only infinitely approximate its object, which is the moral law, artistic production realizes the identity of freedom and necessity in the work of art, and thereby brings this identity to selfconsciousness. Moreover, the artistic production, which results in the inner harmony of the work of art, presents its own inner rule. As mentioned before, in reaching his conclusion that artistic activity-which he calls aesthetic intuition (the objective equivalent of intellectual 
intuition)- presents the ground of the entire system, Schelling deduces a conceptual structure that I have argued forms the Three Conditions of his philosophy of art:

C1. What philosophy constructs in the ideal, art produces in the real. Thus artistic activity is the highest human vocation (Bestimmung) because practical philosophy can only approximate its object, which is the moral law.

C2. While both the natural organism and the artwork embody the same identity of real and ideal, of necessity and freedom, the work of art overcomes these oppositions through the identity of conscious and unconscious production, whereas the organism's activity is unconscious.

C3. Artistic production has a socio-political task: it aims to overcome the fragmentary condition of modernity through a new mythology and artistic renewal.

The purpose of identifying these Three Conditions is to evaluate if- and for how longSchelling remains committed to a philosophy of art. Contrary to a standard interpretation of his work, I have argued that the philosophy of art remains a central preoccupation of Schelling's absolute idealism or system of identity. The metaphysics change- for absolute idealism claims to begin from the standpoint of reason itself, instead of from the self's activity- but during this period Schelling still argues that art presents or realizes what philosophy intuits, or constructs, ideally. Art plays this role because of the priority Schelling gives to the power of imagination (Einbildungskraft): art is the informing (Ineinsbildung) of the infinite into the finite; imagination is the complementary power to philosophical construction, which intuits the universal in the particular. Thus the Philosophy of Art provides a unique answer to the central problem of the system of identity, the problem of finding the transition from the infinite to the finite. 
In the Darstellung meines Systems der Philosophie (1801), Schelling argued that particularity is a matter of quantitative difference, because no qualitative difference is possible within the absolute (see Chapter 4.2). That is, the absolute cannot be negated or limited to create particularity. Instead, Schelling argues that each individual is either of a predominantly real or predominantly ideal potency or magnitude of being. Regardless of Schelling's assertions, however, this argument still has difficulty accounting for the transition from the infinite to the finite because the infinite absolute and finite individuals ultimately differ in quality.

The Philosophy of Art attempts to explain this transition in a unique way, through the historical construction of the mythological content of art (Chapter 4.4). Mythology presents the sensuous informing of the ideas of reason. In this account, however, Schelling encounters a contraction between the formal deduction of substance and the historical construction of mythology. The substance of the system, its first and all-encompassing principle, is an eternal and impersonal God, while the construction of Greek mythology and Christian mythology presents the Greek gods and Christian God as revealed in the finite world. I have argued that Schelling is faced with a contradiction between the first principle, which is absolute and eternal, and historical revelation through mythology. If Schelling maintains the first principle (the absolute, eternal substance), this renders mythology as mere appearances or illusions, yet, to maintain the actuality- or informing- of the revelation of the gods contravenes the form of the immutable, eternal substance.

While this contradiction is not resolved in the Philosophy of Art, in the address Über das Verhältnis der bildenden Künste zu der Natur ${ }^{1}$ (1807), Schelling turns to a historical or revealed account of the development of nature, history and art (Chapter 5). In the Münchener

\footnotetext{
${ }^{1}$ Hereafter referred to as the Münchener Rede.
} 
Rede, Schelling argues that nature's productive power (Urkraft) is repeated in human history and artistic production. So while nature is the ground of art, it is only through art that nature's productivity is revealed. The difference between the Philosophy of Art and the Münchener Rede is that in the latter text substance is revealed in history. Schelling's previous Spinozism gives way to a historical revelation of divine essence through art. At the same time, Schelling presents a self-creating artistic ethos of the Münchener Rede, which was a kind of positive power that could overcome the various passions in the formation of beauty or the sublime in the work of art. This singular ethic unified the true (of nature and science) and the good (in overcoming the passions) through the beautiful, which at the same time reveals the history of nature's production.

In its emphasis on history and revelation, the Münchener Rede, then, prefigures the concerns of the Philosophical Investigations into the Essence Of Human Freedom (1809) and the Stuttgart Seminars (1810). However, in the latter texts, Schelling undergoes a theological turn: his construction of history is no longer oriented toward the production of various, monumental, series of artworks, such as those of Michelangelo-Correggio-Raphael from the Renaissance, nor does he the call for a renewal of art through the proper approach to nature; now, in the Stuttgart Seminars, history is constructed with the inclusion of both the Fall of humanity and Christ's redemption as real events. The focus is no longer on artistic activity, which is relegated in this text to a kind of longing for a lost bond with nature, but rather on the human capacity for good and evil. This capacity is possible because human being exists at the point of indifference, or mediation, between nature and God. The relative independence or distance from both nature and God becomes the basis of human freedom. Thus in Schelling's philosophy, freedom emerges where artistic activity once was. 
In the trajectory from freedom to artistic activity and back to freedom, the path is everything: freedom did not just emerge ex nihilo in Schelling's thought in 1809 or 1810 , it had been slowly developed at first through a philosophy of art as a kind of artistic ethos. Hence this return to freedom is grounded on an entirely different conception than Schelling's early work. Whereas in his more Fichtean phase, Schelling held that freedom was conceived according to the imperative of the moral law, he now holds that freedom demonstrates its own creative power in the finite world through virtue. Freedom is not thought in conformity to the a priori moral law, but is now conceived as an ecstatic act: freedom is possible because humanity stands out from nature and the divine, something, that, in different terms, was once reserved for artistic activity.

Schelling's turn from the ethos of art in favor of a renewal of a universal religion, was to have decisive effects on the reception of his thought, for in post-Enlightenment Germany, through Hegel, Feuerbach and Marx (and even the young Schelling himself, as we saw in Chapter 1), religion itself was in question. Religion became, famously in the work of Marx, a mystified expression of real suffering, of the objective conditions of human activity. Religion in the realm of politics became ever more criticized for oppression, and religious criticism became ever more criticized for obscurantism. We will not render a judgment on the later Schelling, who entered Berlin in 1841 with his system of positive philosophy, to put a stop to the spreading Hegelianism. However, we can say that in his turn toward a universal philosophical religion, Schelling turns away from the ethos of the Philosophy of Art that had demanded of modern art that it collect the fragments of objective life and render them through a totality that could express the objective conditions of human existence. 
Schelling is one of the first modern philosophers to grasp artistic production as a form of criticism, which makes him an important predecessor to those who, a century later, returned art to the forefront of philosophical thought in the $20^{\text {th }}$ century, such as Walter Benjamin, Martin Heidegger, or Alain Badiou. What they share is an important philosophical interest in art- in its truth, or in its activity- despite their differences over what these conditions of human activity are. I have hoped to show that Schelling's philosophy of art merits the same careful attention that is given to his better-known successors. 


\section{Bibliography}

\section{German Editions of Schelling Consulted}

Schelling, F.W.J. Aus Schellings Leben In Briefen. Ed. G.L. Plitt. 3 Volumes (Hildesheim: Georg Olms Verlag, 2003 [Reprint of 1870 edition]).

__ Friedrich Wilhelm Joseph von Schelling. Ausgewählte Schriften. 6 vols. Ed. Manfred Frank (Frankfurt: Suhrkamp, 1985).

— Historisch-kritische Ausgabe. Ed. H.M. Baumgartner, W.G. Jacobs, H. Krings (Stuttgart: Frommann-Holzboog, 1976-).

- Schellings Werke. Nach der Original Ausgabe in neuer Anordnung. 12 vols. Ed. Manfred Schröter (Munich: Beck, 1927-1959).

—_ Stuttgarter Privatvorlesungen. Ed. Miklos Vetö (Turin: Bottega D'Erasmo, 1973).

_ System des transzendentalen Idealismus. Ed. Horst D. Brandt and Peter Müller (Hamburg: Felix Meiner Verlag, 1992).

_ Texte zur Philosophie der Kunst. Ed. Werner Beierwaltes (Stuttgart: Reclam, 2004).

—_ Über das Verhältnis der bildenden Künste zu der Natur. Ed. Lucia Sziborsky (Hamburg: Felix Meiner Verlag, 1983). 


\section{English Editions of Schelling Consulted}

Schelling, F.W.J. "Ages of the World (Second Draft, 1813)," in The Abyss of Freedom/Ages of the World. Trans. Judith Norman (Ann Arbor: University of Michigan Press, 1997).

Ages of the World (Third Draft, 1815). Trans. Jason M. Wirth (Albany: SUNY Press, 2000).

_ Bruno, or, On the Natural and the Divine Principle of Things. Ed. Michael G. Vater (Albany: SUNY Press, 1984).

— "Concerning the Relation of the Plastic Arts to Nature (1807)," trans. Michael Bullock, in Herbert Read, The True Voice of Feeling (London: Faber and Faber, 1968), 323-364.

_ First Outline of a System of the Philosophy of Nature. Trans. Keith R. Peterson (Albany: SUNY Press, 2004).

_ "Further Presentations from the System of Philosophy," trans. Michael Vater, in The Philosophical Forum XXXII No.4 (Winter 2001), 373-397.

- The Grounding of Positive Philosophy: The Berlin Lectures. Trans. Bruce Matthews (Albany: SUNY Press, 2007).

Historical-Critical Introduction to the Philosophy of Mythology. Trans. Mason Richey and Markus Zisselsberger (Albany: SUNY Press, 2007).

Ideas for a Philosophy of Nature. Trans. Errol E. Harris and Peter Heath (Cambridge: Cambridge University Press, 1988).

_ New Deduction of Natural Right," in The Unconditional in Human Knowledge. Ed. Fritz Marti. (Lewisburg: Bucknell University Press, 1980), 221-252. 
“Of the I as Principle of Philosophy, or On the Unconditional in Human Knowledge," in The Unconditional in Human Knowledge. Ed. Fritz Marti. (Lewisburg: Bucknell University Press, 1980), 63-149.

_ "On the Possibility of a Form of All Philosophy," in The Unconditional in Human Knowledge. Ed. Fritz Marti. (Lewisburg: Bucknell University Press, 1980), 38-58.

- On the History of Modern Philosophy. Trans. Andrew Bowie (Cambridge: Cambridge University Press, 1994).

- On University Studies. Trans. E.S. Morgan (Athens, Ohio: Ohio University Press, 1966).

_ Philosophical Inquiries into the Nature of Human Freedom. Trans. James Gutmann (La Salle, IL: Open Court Press, 1936).

_ Philosophical Investigations into the Essence of Human Freedom. Trans. Jeff Love and Johannes Schmidt (Albany: SUNY Press, 2006).

_ "Philosophical Letters on Dogmatism and Criticism," in The Unconditional in Human Knowledge. Ed. Fritz Marti. (Lewisburg: Bucknell University Press, 1980), $156-218$.

_ The Philosophy of Art. Trans. Douglas W. Stott (Minneapolis: Univeristy of Minnesota Press, 1989).

— "Presentation of My System of Philosophy," trans. Michael Vater, in The Philosophical Forum XXXII No.4 (Winter 2001), 339-371.

— Schelling's Treatise on "The Deities of Samotrace." Ed. Robert F. Brown (Missoula, Montana: Scholar's Press, 1974). 
_Selections from Fichte-Schelling Correspondence (1800-1801) in Theory as Practice. Ed. Jochen Schulte-Sasse, et al. (Minneapolis: University of Minnesota Press, 1997), 73-90.

_ _Stuttgart Seminars," in Idealism and the Endgame of Theory. Ed. Thomas Pfau. (Albany, SUNY Press, 1994), 195-243.

_ "System of Philosophy in General and of the Philosophy of Nature in Particular," in Idealism and the Endgame of Theory. Ed. Thomas Pfau (Albany, SUNY Press, 1994), 139-194.

_ System of Transcendental Idealism. Trans. Peter Heath (Charlottesville: University Press of Virginia, 1978).

_ "Treatise Explicatory of the Idealism in the Science of Knowledge (1797)," in Idealism and the Endgame of Theory. Ed. Thomas Pfau (Albany, SUNY Press, 1994), 61-138.

\section{Additional Sources}

Adorno, Theodor. "Reconciliation Under Duress," in Adorno et al. Aesthetics and Politics (London: Verso, 1977), 151-176.

Allison, Henry E. "Kant's Antinomy of Teleological Judgment" in System and Teleology in Kant's Critique of Judgment. Ed. Hoke Robinson. Southern Journal of Philosophy, Vol. 30: Supplement (1991), 25-42.

Altmann, Alexander. Moses Mendelssohn: A Biographical Study (Alabama: The University of Alabama Press, 1973).

Badiou, Alain. The Century. Trans. Alberto Toscano (Cambridge: Polity Press, 2007). 
_ Handbook of Inaesthetics. Trans. Alberto Toscano. (Stanford: Stanford University Press, 2005).

_ Polemics. Trans. Steve Corcoran (London: Verso, 2006).

Baum, Manfred. "The Beginnings of Schelling's Philosophy of Nature," in The Reception of Kant's Critical Philosophy. Ed. Sally Sedgwick (Cambridge: Cambridge University Press, 2000), 199-215.

Baumgartner, Hans Michael. "The Unconditioned in Knowing: I-Identity-Freedom," in The Emergence of German Idealism. Ed. Michael Baur and Daniel O. Dahlstrom (Washington, D.C.: The Catholic University of America Press, 1999), 241-250.

Beiser, Frederick C. Enlightenment, Revolution, and Romanticism (Cambridge, Mass., Harvard: 1992).

- The Fate of Reason: German Philosophy from Kant to Fichte (Cambridge, Mass., Harvard: 1987).

_ German Idealism: The Struggle Against Subjectivism 1781-1801 (Cambridge, Mass., Harvard: 2002).

- The Romantic Imperative: The Concept of Early German Romanticism (Cambridge, Mass., Harvard: 2002).

Benjamin, Walter. "The Work of Art in the Age of Its Technological Reproducibility" in Selected Writings: Volume 3, 1935-1938. Ed. Howard Eiland and Michael W. Jennings (Cambridge, Mass., Belknap/Harvard: 2002), 101-133.

Bowie, Andrew. Aesthetics and Subjectivity: From Kant to Nietzsche (Manchester: Manchester University Press, 1990). 
_ "German Idealism and the Arts" in The Cambridge Companion to German Idealism. Ed. Karl Ameriks (Cambridge: Cambridge University Press, 2000), 239-257.

_ Schelling and Modern European Philosophy (London: Routledge, 1993).

Braeckman, Antoon. "From the Work of Art to Absolute Reason: Schelling's Journey Toward Absolute Idealism," in The Review of Metaphysics 57 (March 2004), 551569.

_ 'The 'Individual Universal': The Socio-political Meaning of the Work of Art in Schelling," Idealistic Studies, vol. 34/1, 67-83.

Breazeale, Daniel. "Check or Checkmate" On the Finitude of the Fichtean Self," in The Modern Subject. Ed. Karl Ameriks and Dieter Sturma (Albany: SUNY Press, 1995), $87-114$

_ "Fichte's Aenesidemus Review and the Transformation of German Idealism," in The Review of Metaphysics 34 (1981), 545-568.

- "The Theory of Practice and the Practice of Theory: Fichte and the "Primacy of Practical Reason,"' in International Philosophical Quarterly, Vol. 36:1 (March 1996), 47-64.

Cassirer, Ernst. The Philosophy of the Enlightenment. Trans. Fritz C.A. Koelln and James P. Pettegrove (Princeton: Princeton University Press, 1951).

Challiol-Gillet, Marie-Christine. Schelling, une philosophie de l'extase (Paris: Presses Universitaires de France, 1998).

David, Pascal. "Schelling : construction de l'art et récusation de l'esthétique," in Revue de Métaphysique et de Morale 2 (2002), 179-191. 
Di Giovanni, George, and H.S. Harris, eds. Between Kant and Hegel: Texts in the Development of Post-Kantian Idealism (Albany: SUNY Press, 1985).

Distaso, Leonardo V. The Paradox of Existence: Philosophy and Aesthetics in the Young Schelling (Dordrecht: Kluwer, 2004).

Dodd, James. "Philosophy and Art in Schelling's System des transzendentalen Idealismus," in The Review of Metaphysics. Vol. 52 (September 1998), 51-85.

Düsing, Klaus. "The Reception of Kant's Doctrine of the Postulates in Schelling's and Hegel's Early Philosophical Projects," in The Emergence of German Idealism. Ed. Michael Baur and Daniel O. Dahlstrom (Washington, D.C.: The Catholic University of America Press, 1999), 201-237.

Eagleton, Terry. The Ideology of the Aesthetic (Oxford: Blackwell Publishers, 1990).

Escoubas, Éliane. "Philosophie de l'art versus esthétique," in Critique, No. 665, December 2001, 972-983.

Esposito, Joseph L. Schelling's Idealism and Philosophy of Nature (Lewisburg: Bucknell University Press, 1977).

Fackenheim, Emil L. The God Within: Kant, Schelling, and Historicity. Ed. John Burbidge (Toronto: University of Toronto Press, 1996).

Fichte, J. G. Early Philosophical Writings. Ed. Daniel Breazeale (Ithaca: Cornell University Press, 1988).

_ J.G. Fichte: Gesamtausgabe der Bayerischen Akademie der Wissenschaften. Ed. Reinhard Lauth, Hans Jacobs, and Hans Gliwitsky (Stuttgard-Bad Cannstatt: Fromann-Holzboog, 1964-). 
_ The Science of Knowledge. Ed. Peter Heath and John Lachs (Cambridge: Cambridge University Press, 1982).

- The System of Ethics. Ed. Daniel Breazeale and Günter Zöller (Cambridge: Cambridge University Press, 2005).

Fichte and Schelling. Correspondance, 1794-1802. Trans. Myriam Bienenstock (Paris:

Presses Universitaires de France, 1991).

Fischbach, Franck. "Différence et correspondence entre les arts chez Hegel et Schelling," in Hegel Jahrbuch 1999: Hegels Ästhetik. Vol. 1. Ed Andreas Arndt, Karol Bal and Henning Ottmann (Akademie Verlag, 2000), 185-195.

Ford, Lewis S. "The Controversy Between Schelling and Jacobi," in The Journal of the History of Philosophy, Vol. 3 (1965), 75-89.

Frank, Manfred. Auswege aus dem Deutschen Idealismus (Frankfurt: Suhrkamp, 2007).

— Der kommende Gott: Vorlesungen über die Neue Mythologie. Vol. 1 (Frankfurt: Suhrkamp, 1982).

_ Der Unendliche Mangel an Sein (Frankfurt: Suhrkamp, 1975).

__ Eine Einführung in Schellings Philosophie (Frankfurt: Suhrkamp, 1985).

- The Philosophical Foundations of Early German Romanticism. Trans. Elizabeth Millán-Zaibert (Albany: SUNY Press, 2004).

Frank, Manfred and Gerhard Kurz, eds. Materialien zu Schellings philosophischen Anfängen (Frankfurt: Suhrkamp, 1975).

Friedman, Michael. "Kant, Skepticism, and Idealism," in Inquiry, vol. 49, n. 1 (February 2006), 26-43. 
George, Theodore D. “A Monstrous Absolute: Schelling, Kant, and the Poetic Turn in Philosophy," in Schelling Now: Contemporary Readings. Ed. Jason M. Wirth. (Bloomington: Indiana University Press, 2005), 135-146.

Goethe, Johann Wolfgang. Berliner Ausgabe. 22 vols. (Aufbau-Verlag, 1965-1978).

- Selected Poems. Ed. Christopher Middleton (Boston: Suhrkamp, 1983).

- The Sorrows of Young Werther. Trans. Burton Pike (New York: The Modern Library, 2005).

Habermas, Jürgen. "Dialectical Idealism in the Transition to Materialism: Schelling's Idea of a Contraction of God and its Consequences for the Philosophy of History," in The New Schelling. Ed. Judith Norman and Alistair Welchman (New York: Continuum, 2004), 43-89.

Hamann, Johann Georg. Writings on Philosophy and Language. Ed. Kenneth Haynes (Cambridge: Cambridge University Press, 2007).

Hamilton Grant, Iain. "'Philosophy Become Genetic': The Physics of the World Soul," in The New Schelling. Ed. Judith Norman and Alistair Welchman (New York: Continuum, 2004), 128-150.

Harris, H.S. Hegel's Development: Toward the Sunlight 1770-1801 (Oxford: Clarendon Press, 1972).

Heidegger, Martin. Basic Writings. Ed. David Farrell Krell (San Francisco: Harper Collins Publishing, 1993).

_ Schelling's Treatise on the Essence of Human Freedom. Trans. Joan Stambaugh (Athens, Ohio: Ohio University Press, 1985). 
Hegel, G.W.F. Gesammelte Werke. Ed. Rheinisch-Westfälischen Akademie der Wissenschaften (Hamburg: Felix Meiner Verlag, 1968-).

_ Hegel's Aesthetics: Lectures on Fine Art. Tr. T.M. Knox (Oxford: Oxford University Press, 1975).

_ The Letters. Trans. Clark Butler and Christiane Seiler, with commentary by Clark Butler (Bloomington: Indiana University Press, 1984),

— The Phenomenology of Spirit. Trans. A.V. Miller (Oxford: Oxford University Press, 1977).

_ Philosophy of Nature. Trans. A.V. Miller (Oxford: Oxford University Press, 1970).

Henrich, Dieter. Between Kant and Hegel. Ed. David S. Pacini (Cambridge, Mass.: Harvard University Press, 2003).

The Course of Remembrance and Other Essays on Hölderlin. Ed. Eckart Förster (Stanford: Stanford University Press, 1997).

Hölderlin, Friedrich. Essays and Letters on Theory. Ed. Thomas Pfau (Albany: SUNY Press, 1988).

_ Sämtliche Werke. Ed. Friedrich Beissner (Stuttgart: Verlag W. Kohlhammer, 19431985).

Huneman, Philippe. "From the Critique of Judgment to the Hermeneutics of Nature: Sketching the Fate of Philosophy of Nature after Kant," in Continental Philosophy Review 39 (2006), 1-34.

Jacobi, Friedrich Heinrich. The Main Philosophical Writings and the Novel Allwill. Ed. George di Giovanni (Montreal; McGill-Queen's University Press, 1994). Jähnig, Dieter. Schelling: Die Kunst in der Philosophie, 2 vols. (Pfüllingen: Neske, 1969). 
Jamme, Christoph, and Helmut Schneider, eds. Mythologie der Vernuft (Frankfurt am Main: Suhrkamp, 1984).

Kant, Immanuel. Critique of the Power of Judgment. Ed. Paul Guyer (Cambridge: Cambridge University Press, 2000).

_ Critique of Practical Reason. Trans. Lewis White Beck (Indianapolis: Bobbs-Merrill Co. Inc., 1956).

_ Critique of Pure Reason. Trans. Norman Kemp Smith. Second Revised Edition (New York: Palgrave, 2003).

_ Critique of Pure Reason. Ed. Paul Guyer and Allen M. Wood (Cambridge: Cambridge University Press, 1998).

_ Gesammelte Werke (Preussischen Akademie der Wissenshaften (Berlin: de Gruyter, 1900-).

- Metaphysical Foundations of Natural Science. Ed. Michael Friedman (Cambridge: Cambridge University Press, 2004).

_ Kant: Selections. Ed. Lewis White Beck (New York: Macmillian, 1988).

Krell, David Farrell. Contagion: Sexuality, Disease, and Death in German Idealism and Romanticism (Bloomington: Indiana University Press, 1998).

_ "The Oldest Program Towards a System in German Idealism," Owl of Minerva, 17: 1 (Fall 1985), 5-19.

- The Tragic Absolute: German Idealism and the Languishing God (Bloomington: Indiana University Press, 2005).

Lachs, John. "Fichte's Idealism," in The American Philosophical Quarterly, Vol. 9:4 (October 1972), 311-318. 
Lacoue-Labarthe, Philipe and Jean-Luc Nancy. L'absolu litteraire (Paris: Seuil, 1978).

Lawrence, Joseph P. "Art and Philosophy in Schelling," in The Owl of Minerva 20 (1988), 519.

_ "Schelling's Metaphysics of Evil," in The New Schelling. Ed. Judith Norman and Alistair Welchman (New York: Continuum, 2004), 167-189.

Leibniz, G.W. Philosophical Texts. Ed. R.S. Woolhouse and Richard Francks (Oxford: Oxford University Press, 1998).

Llewelyn, John. The HypoCritical Imagination: Between Kant and Levinas (London: Routledge, 2000).

Lukács, Georg. The Destruction of Reason. Trans. Peter Palmer (London: Merlin Press, 1980).

Makkreel, Rudolf A. "Regulative and Reflective Uses of Purposiveness in Kant." in System and Teleology in Kant's Critique of Judgment. Ed. Hoke Robinson. Southern Journal of Philosophy, Vol. 30: Supplement (1991), 49-63.

Mandt, A.J. "Fichte's Idealism in Theory and Practice," in Idealistic Studies, Vol. 14:2 (May 1984), 127-147.

Marquard, Odo. "Several Connections between Aesthetics and Therapeutics in NineteenthCentury Philosophy," in The New Schelling. Ed. Judith Norman and Alistair Welchman (New York: Continuum, 2004), 13-29.

Marquet, Jean-François. Liberté et existence. Second Edition (Paris: Les Éditions du Cerf, 2006).

__ "Schelling et le destin de l'art," in Actualité de Schelling. Ed. G. Planty-Bonjour (Paris: Vrin, 1979), 75-88. 
Marx, Karl. Grundrisse. Trans. Martin Nicolaus (New York: Penguin Books, 1973).

_ Selected Writings. Ed. David McLellan (Oxford: Oxford University Press, 1977).

Marx, Werner. The Philosophy of F.W.J. Schelling. Trans. Thomas Nenom (Bloomington: Indiana University Press, 1984).

McFarland, J.D. Kant's Concept of Teleology (Edinburgh: University of Edinburgh Press, 1970).

Merleau-Ponty, Maurice. Nature: Course Notes from the Collège de France. Ed. Dominique Séglard. Trans. Robert Vallier (Evanston: Northwestern University Press, 2003). Morgan, S.R. "Schelling and the origins of his Naturphilosophie," in Romanticism and the Sciences. Ed. Andrew Cunningham and Nicholas Jardine (Cambridge: Cambridge University Press, 1990), 25-37.

Neiman, Susan. Evil in Modern Thought (Princeton: Princeton University Press, 2002).

Neuhouser, Frederick. Fichte's Theory of Subjectivity (Cambridge: Cambridge University Press, 1990).

Nietzsche, Friedrich. The Gay Science. Trans. Walter Kaufmann (New York: Vintage Books, 1974).

The Portable Nietzsche. Ed. Walter Kaufmann (New York: Penguin Books, 1954). Oesterreich, Peter L. "Die Gewalt der Schönheit," in Schellings Weg zur Freiheitsschrift: Legende und Wirklichkeit. Ed. Hans M. Baumgartner, Wilhelm G. Jacobs (StuttgartBad Cannstatt: Frommann Holzboog, 1996), 95-109.

Peter, Klaus. "History and Moral Imperatives: The Contradictions of Political Romanticism," in The Literature of German Romanticism. Ed. Dennis F. Mahoney (Rochester, NY: Camden House, 2004), 191-208. 
Pfau, Thomas, ed. Idealism and the Endgame of Theory. (Albany, SUNY Press, 1994).

Piché, Claude. "Fichte et la première philosophie de la nature de Schelling," in Dialogue, vol. XLIII, no. 2 (Spring 2004), 211-237.

Pippin, Robert B. Hegel's Idealism: The Satisfactions of Self-Consciousness (Cambridge: Cambridge University Press, 1989).

Rancière, Jacques. Malaise dans l'esthétique (Paris, Galilée : 2004).

Reidhold, K.L. "The Foundation of Philosophical Knowledge (Excerpt)," in Between Kant and Hegel: Texts in the Development of Post-Kantian Idealism. Eds. George di Giovanni and H.S. Harris (Albany: SUNY Press, 1985), 52-103.

Richards, Robert J. The Romantic Conception of Life (Chicago: University of Chicago Press, 2002).

Rosen, Charles. Arnold Schoenberg (Princeton: Princeton University Press, 1975).

Schaffer, Simon. "Genius in Romantic Natural Philosophy," in Romanticism and the Sciences. Ed. Andrew Cunningham and Nicholas Jardine (Cambridge: Cambridge University Press, 1990), 82-98.

Schiller, Friedrich. On the Aesthetic Education of Man. Trans. Elizabeth M. Wilkinson and L.A. Willoughby (Oxford: Oxford University Press, 1982).

Schmied-Kowarzik, Wolfdietrich. "Kunst zwischen Natur, Geschichte und Absolutem bei Schelling und Hegel" in Hegel Jahrbuch 1999: Hegels Ästhetik. Vol. 1. Ed Andreas Arndt, Karol Bal and Henning Ottmann (Akademie Verlag, 2000), 178-184.

Schueller, Herbert M. "Schelling's Theory of the Metaphysics of Music," in The Journal of Aesthetics and Art Criticism. Vol. 15 n. 3 (1957), 461-476. 
Schulze, G.E. "Aenesidemus (excerpt)," in Between Kant and Hegel: Texts in the Development of Post-Kantian Idealism. Eds. George di Giovanni and H.S. Harris (Albany: SUNY Press, 1985), 104-135.

Sedlar, Jean W. India in the Mind of Germany (Washington, D.C.: University Press of America, 1982).

Seebohm, Thomas M. "Fichte's Discovery of the Dialectical Method," in Fichte: Historical Contexts, Contemporary Controversies. Ed. Daniel Breazeale and Tom Rockmore (New Jersey: Humanities Press, 1994), 17-42.

Seidel, George J. "Creativity in the Aesthetics of Schelling," in Idealistic Studies, Vol. 4, no. 2 (May 1974), 170-180.

Snow, Dale E. Schelling and the End of Idealism (Albany: SUNY Press, 1996).

Spinoza, Baruch. Ethics, Treatise on the Emendation of the Intellect, and Selected Letters. Trans. Samuel Shirley (Indianapolis: Hackett, 1992).

Sturma, Dieter. "The Nature of Subjectivity: The Critical and Systematic Function of Schelling's Philosophy of Nature." in The Reception of Kant's Critical Philosophy. Ed. Sally Sedgwick (Cambridge: Cambridge University Press, 2000), 216-231.

_ "Politics and the New Mythology: The Turn to Late Romanticism," in The Cambridge Companion to German Idealism. Ed. Karl Ameriks (Cambridge: Cambridge University Press, 2000), 219-238.

Summerell, Orrin F. "The Theory of the Imagination in Schelling's Philosophy of Identity" in Idealistic Studies, Vol. 34, no. 2 (2004), 85-98. 
Sziborsky, Lucia. "Schelling und die Münchener Akademie der bildenden Künste" in Welt und Wirkung von Hegels Ästhetik. Ed. Annemarie Gethmann-Siefert and Otto Pöggeler (Bonn: Bouvier Verlag Herbert Grundmann, 1986), 39-64.

Szondi, Peter. An Essay on the Tragic. Trans. Paul Fleming (Stanford: Stanford University Press, 2002).

Tilliette, Xavier. La mythologie comprise (Naples: Bibliopolis, 1984).

_ "The Problem of Metaphysics," in The Emergence of German Idealism. Ed. Michael Baur and Daniel O. Dahlstrom (Washington, D.C.: The Catholic University of America Press, 1999), 251-266.

__ “Schelling als Verfasser des Systemprogramms?" in Das älteste Systemprogramm. Ed. Rüdiger Bubner (Bonn: Bouvier Verlag Herbert Grundmann, 1973), 35-52.

__ Schelling: Biographie (Paris: Calmann-Lévy, 1999).

__ "Schelling, l'art et les artistes," in Schelling, Textes esthétiques. Trans. Alain Pernet (Paris: Editions Klincksieck, 1978), xi-xlvii.

_ Schelling. Une philosophie en devenir. 2 vols. (Paris: Vrin, 1970).

Toscano, Alberto. "Philosophy and the Experience of Construction," in The New Schelling. Ed. Judith Norman and Alistair Welchman (New York: Continuum, 2004), 106-127. Vallée, Gérard, ed. The Spinoza Conversations Between Lessing and Jacobi (New York: University Press of America, 1988).

Vaysse, Jean-Marie. Schelling: Art et mythologie (Paris, Ellipses, 2004).

Velkley, Richard L. "Realizing Nature in Self: Schelling on Art and Intellectual Intuition in the System of Transcendental Idealism," in Figuring the Self. Ed. David E. Klemm and Günter Zöller (Albany: SUNY Press, 1997), 149-168. 
Verra, Valerio. "La 'construction' dans la philosophie de Schelling," in Actualité de Schelling. Ed. G. Planty-Bonjour (Paris: Vrin, 1979), $27-47$.

White, Alan. Schelling: An Introduction to the System of Freedom (New Haven: Yale, 1983).

Williamson, George S. The Longing for Myth in Germany (Chicago: University of Chicago Press, 2004).

Wirth, Jason M. The Conspiracy of Life: Meditations on Schelling and His Time (SUNY Press, 2003).

Žižek, Slavoj. "The Abyss of Freedom," in The Abyss of Freedom/Ages of the World (Ann Arbor: University of Michigan Press, 1997).

- The Indivisible Remainder: An Essay on Schelling and Related Matters (London: Verso, 1996). 